\title{
The politics of style
}

Citation for published version (APA):

Schoor, C. (2020). The politics of style: political performance caught between populism, elitism, and pluralism. [Doctoral Thesis, Maastricht University]. ProefschriftMaken.

https://doi.org/10.26481/dis.20200824cs

Document status and date:

Published: 01/01/2020

DOI:

$10.26481 /$ dis.20200824cs

Document Version:

Publisher's PDF, also known as Version of record

\section{Please check the document version of this publication:}

- A submitted manuscript is the version of the article upon submission and before peer-review. There can be important differences between the submitted version and the official published version of record.

People interested in the research are advised to contact the author for the final version of the publication, or visit the DOI to the publisher's website.

- The final author version and the galley proof are versions of the publication after peer review.

- The final published version features the final layout of the paper including the volume, issue and page numbers.

Link to publication

\footnotetext{
General rights rights.

- You may freely distribute the URL identifying the publication in the public portal. please follow below link for the End User Agreement:

www.umlib.nl/taverne-license

Take down policy

If you believe that this document breaches copyright please contact us at:

repository@maastrichtuniversity.nl

providing details and we will investigate your claim.
}

Copyright and moral rights for the publications made accessible in the public portal are retained by the authors and/or other copyright owners and it is a condition of accessing publications that users recognise and abide by the legal requirements associated with these

- Users may download and print one copy of any publication from the public portal for the purpose of private study or research.

- You may not further distribute the material or use it for any profit-making activity or commercial gain

If the publication is distributed under the terms of Article $25 \mathrm{fa}$ of the Dutch Copyright Act, indicated by the "Taverne" license above, 


\title{
The Politics of Style
}

\author{
Political Performance Caught Between \\ Populism, Elitism, and Pluralism
}

Carola Schoor 
The Politics of Style. Political Performance Caught Between Populism, Elitism, and Pluralism ISBN 978-94-6380-865-I

(C) copyright Carola Schoor 2020

Printed by: Proefschriftmaken.nl

Illustrations cover and chapter pages: Loek Weijts

Lay-out cover: Loek Weijts

Layout inside pages and graphs: Carola Schoor

Publisher: Maastricht University

All rights reserved. Save exceptions stated by law, no part of this publication may be reproduced, stored in a retrieval system of any nature, or transmitted in any form by any means, electronic, mechanical, photocopying, recording or otherwise, included a complete or partial transcription, without the prior written permission of the proprietor. 


\title{
The Politics of Style
}

\section{Political Performance Caught Between Populism, Elitism, and Pluralism}

\author{
DISSERTATION \\ To obtain the degree of Doctor at Maastricht University \\ on the authority of the Rector Magnificus, \\ Prof. dr. Rianne M. Letschert \\ in accordance with the decision of the Board of Deans, \\ to be defended in public \\ on Monday, 24 August 2020 \\ at 14.00 hours
}

by

Catharina Elisabeth (Carola) Schoor

Born in 's-Hertogenbosch, The Netherlands 
Supervisor: $\quad$ Dr. Sjaak Koenis, Maastricht University

Co-supervisor: Dr. Jan de Roder, Maastricht University

Assessment Committee:

Prof. Dr. Tannelie Blom, Maastricht University (Chair)

Dr. Emilia Palonen, University of Helsinki

Prof. Dr. John Parkinson, Maastricht University

Dr. Matthijs Rooduijn, University of Amsterdam

Prof. Dr. Simon Tormey, University of Bristol

Faculty of Arts and Social Sciences (FASoS), Maastricht University, The Netherlands 


\section{Table of Contents}

List of Tables and Figures $\quad$ x

Acknowledgements $\quad$ xii

I INTRODUCTION

Political Style, a Matter of Grave Importance?

I Main Topic 2

2 Political Style and Populism 5

3 The Analysis Instrument 6

3.I PEP-index version 0 (unpublished).

3.2 PEP-index version I. 9

3.3 PEP-index version $2 . \quad 10$

3.4 PEP-index version 2+ I5

4 Outline of the Dissertation $\quad$ I5

2 POLITICAL STYLE THEORY 19

Because We Never Go Out of Style

I Introduction 20

2 Political Style as Performance 23

3 Political Style as Ideological Discourse $\quad 25$

4 Three Basic Tensions in Discourse $\quad 27$

5 The Three Dimensions of Political Style $\quad 30$

6 Five Focus Elements of Political Style $\quad 32$

6.I Focus elements in the presentational dimension. 33

6.2 Focus elements in the social dimension.

6.3 Political style in five elements. $\quad 35$

7 Style Labels $\quad 36$

8 Political Style and Metaphor $\quad 40$

9 Conclusion 4 4I

3 IN THE THEATER OF POLITICAL STYLE

Touches of Populism, Pluralism, and Elitism in Speeches of Politicians

I Introduction 44

2 Ideology Changing Form $\quad 46$

3 Three Dimensions Within Political Style $\quad 47$ 
4 Political Style and the Theatre Concept 50

5 Defining Core Traits of Political Style 5 I

6 Political Style of Trump, Sanders, and Clinton 56

6.I Donald Trump. 58

6.2 Hillary Clinton. $\quad 59$

6.3 Bernie Sanders. 61

6.4 Conclusions of the Analysis. $\quad 62$

7 Conclusion and Discussion $\quad 64$

4 PROBING INTO POPULISM'S CORE $\quad 67$

An Analysis of the Deep Semio-linguistic Structure of Populism I Introduction 68

2 Logic Versus Common Sense $\quad 70$

3 Greimas $\quad 72$

4 Populism Opposed to Elitism and Pluralism $\quad 75$

4.I Populism versus elitism.

$\begin{array}{ll}4.2 \text { Populism versus pluralism. } & 77\end{array}$

$\begin{array}{ll}4.3 \text { Elitism versus pluralism. } & 78\end{array}$

$\begin{array}{ll}4.4 \text { Triangular relation. } & 79\end{array}$

5 Groups, Individuals, and Systems $\quad 80$

6 From Individualism to Populism: One Logical Way and One Shortcut 83

7 Framings of Populism 86

8 Contested Cases $\quad 88$

9 Conclusion $\quad 90$

5 CAUGHT BETWEEN POPULISM, ELITISM, AND PLURALISM

A Method for Political Discourse Analysis

I Introduction 92

2 Multidimensional Approach $\quad 94$

3 Semiotic Analysis $\quad 96$

4 A Method for Speech Analysis I0I

5 The Analysis 104

6 Who is the Real US Populist? 106

6.I Obama's political style. 107

$\begin{array}{ll}6.2 \text { Trump's political style. } & 108\end{array}$ 
6.3 Sanders' political style. 108

6.4 Obama, Trump, and Sanders compared. 109

7 Three kinds of populism in the UK 109

$\begin{array}{ll}7 . I \text { Farage's political style. } & 110\end{array}$

7.2 Johnson's political style. III

$\begin{array}{ll}7.3 \text { Corbyn's political style. } & 112\end{array}$

7.4 Farage, Johnson, and Corbyn compared. II3

8 Three Full Populists in The Netherlands $\quad$ II4

8.I Wilders' political style. $\quad 1 / 4$

8.2 Baudet's political style. $\quad$ II5

8.3 Roemers' political style. $\quad 115$

8.4 Wilders, Baudet, and Roemers compared. 116

9 Discussion and Conclusion $\quad 116$

6 WHERE THE REAL PEOPLE MEET THE REAL ELITE I 9 Exploring Mixes of Populism with Elitism

$\begin{array}{ll}\text { I Introduction } & 120\end{array}$

2 A Semiotic Analysis of Populism, Elitism, and Pluralism $\quad 122$

3 A Triangular Framework for Political Analysis $\quad 126$

4 Donald Trump: A People's President for an Elite People $\quad 130$

5 Boris Johnson: Letting the People "Roar" 133

6 Thierry Baudet: Showing Off with Superiority 135

7 Conclusion and Discussion $\quad 138$

7 POLITICAL METAPHOR, A MATTER OF PURPOSEFUL STYLE I I On the Rational, Emotional, and Strategic Purposes of Political Metaphor I Introduction $\quad 142$

2 Rhetoric and the Debate on Metaphor in Discourse $\quad 144$

3 Aristotle's View of Metaphor: Not a Fallacy After All $\quad 145$

4 Aristotle's Metaphor as an Answer to Flattery and Deceit 147

5 Aristotle's Metaphor in Relation to Imagination and Thought $\quad 149$

6 Where Aristotle Meets Conceptual Metaphor Analysis $\quad 150$

7 Application in Political Metaphor Analysis $\quad 153$

7.I Emotion-based metaphor. $\quad 155$

$\begin{array}{ll}7.2 \text { Strategy-based metaphor. } & 156\end{array}$ 
7.3 Reason-based metaphor. $\quad 156$

$\begin{array}{ll}7.4 \text { Interaction between purposes and metaphors. } & 157\end{array}$

8 Contribution to Discussion $\quad 158$

9 Conclusion $\quad 160$

8 THE PEOPLE AS HEROES, ANIMALS, OR THE COUNTRY? I6I Metaphor in Populist and Non-Populist Political Discourse

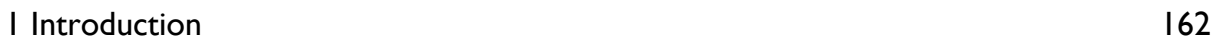

2 Political Style and Populism Theory 163

3 Metaphor Theory $\quad 167$

4 Obama: The People as America $\quad 169$

$\begin{array}{ll}\text { 4.I The people. } & 170\end{array}$

$\begin{array}{lll}4.2 \text { The elite. } & \text { I7I }\end{array}$

4.3 Politics and democracy/government. I7]

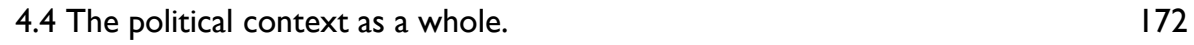

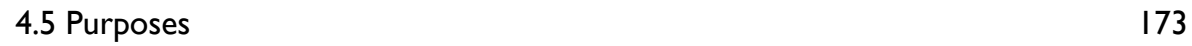

5 Johnson: The People as Animals or Slaves $\quad 173$

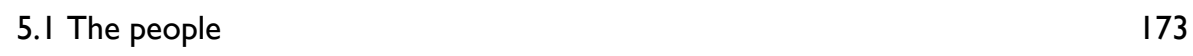

$\begin{array}{ll}5.2 \text { The elite } & 174\end{array}$

$\begin{array}{ll}5.3 \text { Politics and democracy/government } & 175\end{array}$

$\begin{array}{ll}5.4 \text { The political context } & 176\end{array}$

$\begin{array}{ll}5.5 \text { Purposes } & 176\end{array}$

6 Wilders: The People as Heroes, Liberating the Country 176

$\begin{array}{ll}\text { 6.I The people } & 177\end{array}$

$\begin{array}{ll}6.2 \text { The elite } & 178\end{array}$

$\begin{array}{ll}6.3 \text { Politics } & 178\end{array}$

6.4 Democracy/government and political context $\quad 178$

$\begin{array}{ll}6.5 \text { Purposes } & 179\end{array}$

$\begin{array}{ll}7 \text { Conclusion and Discussion } & 180\end{array}$

9 CONCLUSION $\quad 183$

Political Style, a Matter of Framing

$\begin{array}{ll}\text { I.I Three-dimensional style. } & 184\end{array}$

$\begin{array}{ll}\text { I.2 Left-right-center politics and political style. } & \text { I86 }\end{array}$ 
I.3 Mixing personal, group and systematic styles.

2 Contributions to the populism concept

2.I The nature of populism.

2.2 The missing link between various populism approaches.

2.3 A non-heterogeneous people as part of populism.

2.4 An inter-contextual definition.

2.5 Three political acts.

3 Contribution to the Political Metaphor Concept

4 Contribution to Political Analysis Methods 201

5 Contribution to the Literature on Current Politics 203

6 The Politics of Style 205

\section{APPENDICES}

Appendix A: Speech List

Appendix B: Subscores

Appendix C: Inductive versus Structural features of populism 223

Appendix D: Six Political Styles Relatively Defined

REFERENCES

Relevance 256

Stakeholders 258

People working in politics. 258

A politically active public. 259

Watchdogs over our democracy. 260

Activities 260

In the future 


\title{
List of Tables and Figures
}

\author{
List of Tables
}

Table 3.I Analysis of the frontstage of politics related to

Goffmann's (1956) and Reisigl and Wodak's (2015) definitions. 52

Table 3.2 Populism, pluralism, and elitism compared on five core traits. 55

Table 3.3 Rubric of the politcial-style element The People. 57

Table 5.I Van Dijk's (1998, 2013) cognitive-functional structure of ideologies applied to populism. $\quad 95$

Table 5.2 Main features of populism, elitism, and pluralism in one framework. 99

Table 6.I Main features of populism, elitism, and pluralism in relation to $\begin{array}{ll}\text { each other. } & 128\end{array}$

$\begin{array}{lll}\text { Table 8.I Purposes of Obama's metaphor usage. } & \text { I72 }\end{array}$

Table 8.2 Purposes of Johnson's metaphor usage. $\quad 175$

$\begin{array}{lll}\text { Table 8.3 } & \text { Purposes of Wilders' metaphor usage. } & \text { I79 }\end{array}$

\section{List of Figures}

Figure I.I The political styles of twenty Dutch politicians between 1946 and 2012, analyzed with PEP-index version 0.

Figure I.2 A Venn-diagram of populist, elitist, and pluralist features, at one element.

Figure I.3 A fragment of a coded speech of Boris Johnson in 2016.

Figure $1.4 \quad$ Political styles of three political contexts (the US, the UK, and the Netherlands) analyzed in the PEP-index 2.

Figure I.5 The relation between the chapters in this dissertation and the three levels of discourse in which political style manifests itself.

Figure 2.I A political style as a group style in one dominant framing, incorporating individual and systematic elements.

Figure 3.I Political style in total and on five traits separately, of three candidates in the US primaries, April 2016.

Figure 4.I The semiotic square of A.J. Greimas in a flexible application. 
Figure 4.2 Three semiotic analyses of populism, elitism, and pluralism, and the three analyses combined in one core-structure.

Figure 4.3 Populism as collectivism, in relation to technocracy, institutionalism, and individualism.

Figure 4.4 The core structure of populism related to different approaches to populism.

Figure 5.I The concepts of populism, elitism, and pluralism with shifting relationships in three dimensions.

Figure 5.2 The triangular relationship between populism, elitism, and pluralism. I0 I

Figure 5.3 Political styles and anti-styles in five elements and three dimensions. 103

Figure 5.4 A fragment of a coded speech of Boris Johnson in 2016.

Figure 5.5 The political styles of nine politicians plotted on a triangular field, capturing them as a mix of populism, elitism, and pluralism.

Figure 6.I A semiotic analysis of the concepts populism, elitism, and pluralism.

Figure 6.2 A triangular framework, depicting the logical ties between populism, elitism, and pluralism at three levels.

Figure 6.3 The political styles of speeches plotted on a triangular framework based on the logic between populism, elitism, and pluralism.

Figure 7.I Where Aristotle meets Conceptual Metaphor Theory (CMT).

Figure 7.2 Three purposes for political metaphor.

Figure 8.1 Twenty speeches (listed in Appendix A) analyzed on political style.

The three circled speeches are further analyzed on metaphor usage. 166

Figure 9.I The triangular framework projected onto the horseshoe model.

Figure 9.2 Populism, elitism, and pluralism as three realistic group styles, each mixing personal, group, and systematic style features.

Figure 9.3 The semio-linguistic structure underlying populism.

Figure 9.4 A Greimassian analysis of the opposition between a heterogeneous versus a non-heterogeneous people. 


\section{Acknowledgements}

Throughout the last decade I have had the tremendous opportunity to explore new places. Not only have I lived abroad - in Luxembourg and New York, two places that could not be any more different-I also started a new career path. Having worked as a journalist, communication advisor, and lobbyist in and around politics for around twenty-five years, I decided to look at politics and political language from an academic perspective by starting this $\mathrm{PhD}$ project.

This has been one of the best choices I have made in my life. I am truly grateful for the time I had, not only in enjoying living abroad and meeting new people there, but above all in profoundly exploring the academic field on the boundaries of language, politics, and philosophy. The two persons who made this experience the best imaginable are my promotor and co-promotor Sjaak Koenis and Jan de Roder. They were generous enough to give me a chance to re-enter academics decades after I had finished my master's studies. They were always kind, extremely patient and encouraging, and their critiques always made a great deal of sense. They have changed me from a journalistic writer into a scholar, and there is no doubt that they are responsible for making this $\mathrm{PhD}$ project into the great experience that is was. Their reviews of my work - discussed either in person in Maastricht or through Skype - gave me ample food for thought. My visits to Maastricht always ended in pleasant dinner conversations that I already dearly miss. Also, I want to thank Tsjalling Swierstra for his involvement and his good advice, and Sabine Kuipers for her help with the procedures. I am also grateful for the comments of Joke Spruyt on chapter 8 of this dissertation, the chapter that was published first.

Where-ever I lived, there were always people willing to lend their ears and eyes. In Luxembourg, Isette Reuder always listened and encouraged me to go on. From a distance in the Netherlands, Mirke Beckers, Simone van den Broek, Astrid Schutte, and my sisters Hanke and Margriet Schoor listened to my stories or read my writings. At the time, according to Sjaak and Jan, my articles were still more journalistic than academic. But I learned, and by the time we left Luxembourg for New York, I had my first article published in an academic journal. At this stage, Steve McNally was of great help in tutoring me in English. Later on, various other people helped me with correcting my English, amongst which are Marieke Krijnen and Lara Govea — thank you for that. 
In New York, I was lucky enough to find the best academic writing group ever: Jeanette Hannaford, Amanda Beardsley, and Ami Sengupta. Ladies, we rocked. Under the motto exploring the city while working we found many inspiring working spots that made the whole enterprise so enjoyable. Whether we were in the Ludlow lounge, the study of the Arlo or Nomad, or in WeWork. At a wobbly table in Bryant park, in the bookstore of Housing Works, or between the paintings of the Met; we always combined hard work with pleasure. You were the best of all those good experiences in New York. I am proud and happy to know you and thank you for the good company, the advice, the English lessons, and the edits of my work.

In New York, I also I enjoyed meeting up and discussing academic matters in the Judith Butler Cocktail Club and various Meetup groups. The JBCC was inspiring as well as fun. Jeanette, thanks for letting me be your co-organizer, it was just wonderful to work by your side. At the Academic Writing Meetup group, I met Cornelia Steiner and Michelle Thompson. Thanks Cornelia, for your passionate drive that always gave me another energy boost. Michelle; thanks for hosting the Academic Writing meetup. It was great to meet up with so many different scholars, all working remotely on their projects.

During the last years of this $\mathrm{PhD}$ project I have visited various academic conferences on the topics of political discourse and populism. It has been such a pleasure to meet people who, like me, don't mind talking about populism all day for several days in a row. I truly hope that I can continue to visit such meetings, whichever the way it is that I will proceed with my work. I also want to thank the editors and anonymous reviewers of the journals and books in which six chapters of this dissertation have been, or soon will be, published. Their comments have contributed significantly to the chapters, and to my development as a scholar.

Outside academia, I discussed my ideas with many people, trying to see if I could explain my findings in plain language. Thank you for your advice, especially Hein-Jan Keijzer, Wim Coenraadts, and Mirke Beckers. It is still a challenge to get this whole thing communicated, which is a disgrace for a communication professional such as myself. I shall have to learn to forget the scholar in me from time to time.

Most of all, I want to thank my family. First, of course, Frits Kemperman, my love, who seduced me to step out of my routines and make this journey with him together. Without you, I would never have started or finished this. You always wanted to hear what I had encountered throughout my day with Aristotle, Greimas, or Trump. There were days 
that I was so fed up with the discourse that I had set myself to analyze; luckily, at the end of the day, discussing my findings with you always made me realize that it was worth the effort.

I also want to thank my children, Leonoor and Sander Kemperman. Sander, the discussions in New York on Donald Trump and Bernie Sanders were invaluable. You made me understand why so many young people could not vote for the establishment, and what it is to feel "the Bern." And Leonoor, it was so special to work alongside you in New York and this winter in The Hague: you, writing on your Bachelor thesis, me finalizing the conclusion. We have made it!

Lastly, I want to thank my parents. Bep, thank you for never losing the faith that my dissertation would be finalized "soon," although I was always wrong in the estimated time of arrival, except for now of course. And Han, thank you so much for staying around a little while longer and being here. I am the luckiest daughter in the world with parents like you two. You taught me to finish what I started and to think critically for myself. But you also set an example by showing me that being kind to other people never hurts. To the both of you, I dedicate this dissertation.

The Hague, June, 2020 


\section{I \\ Introduction}

Political Style, a Matter of Grave Importance?

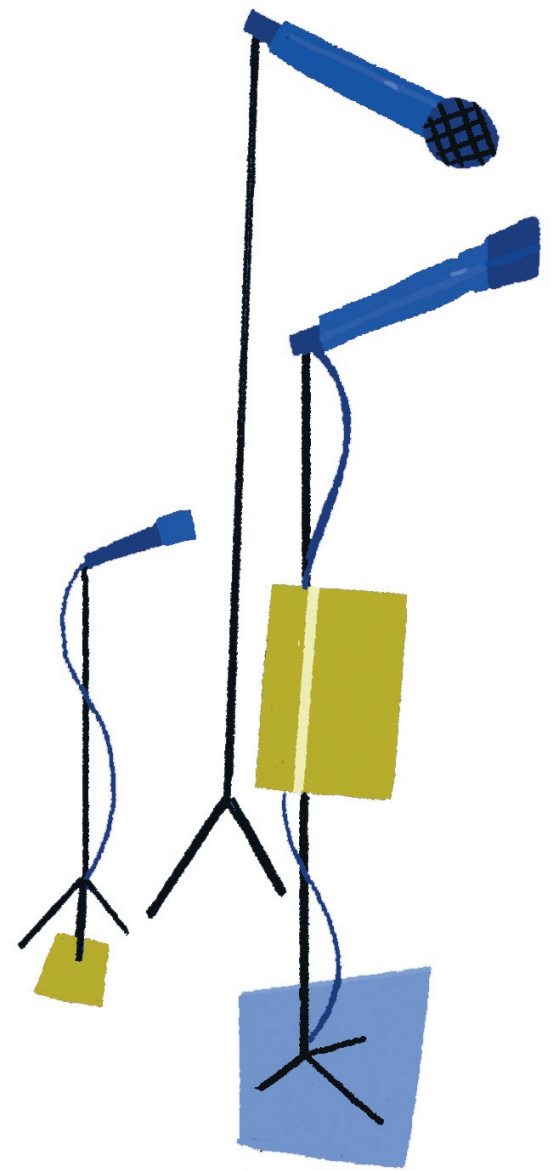


In matters of grave importance, style, not sincerity is the vital thing. Oscar Wilde, The Importance of Being Earnest, act III

\begin{abstract}
This introductory chapter briefly explains the main topic of the dissertation: political style, defined as the entire performance of politicians. As most chapters take the form of independently published articles, this introduction shows their mutual relation and the way in which they contribute to answering the overarching question of this dissertation: how to assess political performance in a way that contributes to our understanding of current politics?
\end{abstract}

\title{
I Main Topic
}

In the last fifty years, the mediazation of politics has placed an increasing emphasis on the role of the entire performance of politicians. In our "audience" or "spectator democracy" (Green, 2010; Manin, 1997), it no longer mostly matters what politicians say; the manner in which they express themselves — the way they speak, look, and act-has gained great influence (Corner, 2003; Corner \& Pels, 2003; Edelman, 1988; Pels \& Te Velde, 2000; Street, 2003). In order to understand current politics, we not only have to understand the meaning of the various expressed ideas; somehow, we must make sense of what is expressed in the images and soundbites that accompany these ideas.

For instance, in Britain, what does it mean that Nigel Farage drinks yet another pint of beer in the pub, in front of a camera? And what does Boris Johnson's messy hairstyle tell us? In the US, why was Hillary Clinton's presentation in the 2016 presidential campaign received as unauthentic? And why is Donald Trump able to get away with every insult he makes? In the Netherlands, why did Thierry Baudet start his maiden speech in parliament in Latin? And is there a political meaning to Dutch prime minister Mark Rutte personally mopping the floor after he had accidentally spilled a cup of coffee? 
Until now, there has been no comprehensive framework for analyzing political performances as a whole. In order to get a better grip on the meaning of the entire political presentation, which I call political style, I developed a theoretical framework that can be used to assess the performances of politicians. Drawing on Van Dijk (1998, 20I5), three dimensions of the political performance are discerned; first, the ideational dimension-this concerns the traditional field of the expressed ideas. Second, the social dimension-the relational aspects; to which group in society do politicians express belonging, and, consequently, which group gains power when a politician is elected? The third dimension is the presentational or rhetorical: do politicians identify with the people they represent, and speak directly for them? Or do they speak of the represented people in a manner that distances themselves from the people; speaking with them and over them?

In order to adequately assess the performance of politicians within these three dimensions, it is necessary to have meaningful labels for political style. These were found in the concepts of populism, elitism, and pluralism: concepts wherein analysis in this dissertation has shown that the shared features of two concepts precisely contradict the third-each dimension in a different constellation:

- In the presentational dimension, populism is precisely the opposite of the shared features of pluralism and elitism; populists identify with the people rather than represent people.

- In the social dimensions, elitism is precisely the opposite of the shared features of pluralism and populism; politicians are either part of the elite or part of the people(s).

- In the ideational dimension, pluralism is precisely the opposite of the shared features of elitism and populism; the people are either heterogeneous or seen as one.

Further analysis in this dissertation revealed that this grammar of meaning, shared by populism, elitism, and pluralism, traces back to the three main tensions in discourse, as defined by De Saussure (Culler, 1976; De Saussure, 1916/2015). This explains why populism has a partly contradictory meaning; these contradictions are inherent to discourse in general. The social dimension of discourse traces back to the tension between signifier and signified, which is an arbitrary relation based on power. The ideational dimension traces back to the 
tension, within the language system, between multiple signifiers forming a syntagmatic relationship. The categorization of groups of signifiers constitutes a tension between a genus and the species of which the genus consists. The presentational dimension traces back to the tension in discourse use, which exploits the paradigmatic relationship between signifiers. This is based on the difference between metaphor and metonymy, based on identification or representation. The precise relationship between these is exemplified in Chapters 2 and 4, but, generally, the relation between populism and discourse is that in the ideational dimension, a populist takes the position of the genus (taking the perspective of the whole; the people instead of individuals). In the social dimension a populist takes the position of the signified (the powerless, instead of the powerful). In the presentational dimension the populist takes the position of the metaphor (identifying with the signified, instead of relating to it). This analysis points at the particular link between populism and metaphor, which is examined in more depth in chapters 7 and 8.

Expressions of populism in different dimensions form an inseparable knot of meanings that are directly related to elitism and pluralism, of which it is difficult to make sense. However, looking at the three concepts in each dimension separately, they form a practical set of style labels, as in each dimension they cover all possible political presentations in a meaningful way. Their related meanings allowed me to use the three concepts as the core of a speech analysis tool, which I developed over the course of this dissertation. As a set of related concepts, populism, elitism, and pluralism provide clear yes and no political categories within the three dimensions. Based on the discursive elements of the political field, five focus elements of political style were distinguished, and then used to compare speech analyses in a comprehensive way. Combining the scores of three dimensions and five focus elements after the speech analysis allows us to transform the messy knot of meanings into a profound insight into the political presentation of politicians.

By providing insight into the political style concept, as well as crafting a tool for assessing political style, this dissertation connects different populism approaches. This is described in section 2 of this chapter. Section 3 briefly describes the development of the speech analysis tool and summarizes the speech analyses conducted. Section 4 gives an outline of the dissertation. 


\section{Political Style and Populism}

Populism is one of the most hotly debated issues in current social science discourse. Until now, there has been no consensus on the exact nature of the phenomenon. Some scholars see populism as predominantly a set of ideas (e.g., Hawkins \& Kaltwasser, 2017; Mudde, 2004, 2017), others emphasize that it is a (discursive) strategy (e.g., Laclau, 2005a; Stavrakakis, 2017; Weyland, 2017), or a political movement (e.g., Aslanidis, 2018; Gerbaudo, 2017; Laclau, 2005a). Mapping the logical structure that underlies the political style labels of populism, elitism, and pluralism, served to reveal a framework that connects the different populism approaches.

Although many scholars acknowledge that there are multiple dimensions to populism, no one validates the three frames equally. Simultaneously validating three frames equally is impossible, because a coherent definition of populism is only available if the parts of the dimensions that exclude each other are completely banned from the definition. More concretely: when framing populism as a "set of ideas," it is necessary to place the anti-elite feature of populism - which it shares with pluralism - between brackets. For instance, Mudde's (2017) ideational definition of populism places the spotlight on the homogeneity of the people. For this reason, Mudde has difficulties explaining political practices that combine clearly populist anti-elite elements (populism in the social dimension) with a pluralist definition of the people (in the ideational dimension). Only the social expressions of populism that do not conflict with the main ideational frame, such as "democracy following the 'general will' of the people," are included in the ideational definition. Müller (2016; 20I5) also restricts populism to political practices which combine anti-elitism with anti-pluralismthis logically follows from the ideational main perspective which he uses to study the phenomenon.

On the other hand, framing populism mainly in the social dimension necessitates hiding the ideational commonalities of populism and elitism in order to maintain a coherent definition. For instance, Laclau and Mouffe's (Laclau, 2005a; Mouffe, 2018a) definition of populism as a social discursive strategy places the spotlight on power relations and automatically eliminates from its definition the ideational side that populism shares with elitism; a purely homogeneous people cannot be part of this definition, as it would contradict populism's status as an act of unifying the people against the group in power.

Lastly, framing populism as "presentation" or "rhetoric" necessitates neglecting the fact that 
populism also shares features with elitism and pluralism, respectively. Hence, only the features in which populism differs from both are considered truly populist. For instance, Weyland (2017) only considers practices in which the political leader identifies with the people as populist. Logically, a presentational definition has to ban leaderless populism (in the social or ideational dimension) from its definition in order to maintain internal consistency.

Because all dimensions contradict parts of other dimensions, the discussion cannot, per definition, be settled; as the semiotic analysis in Chapter 4 reveals, populism has a contradictory meaning in three dimensions which is only visible when looking at the dimensions separately. My claim is that none of the three dimensions is dominant, as each dimension is both the cause and effect of the two others. Hence, populism is simultaneously all three dimensions. Designating one dimension as being the most important for populism inevitably means neglecting certain aspects of the concept, as not all aspects are coherent from only one main perspective. The only way to approach populism more comprehensively is to analyze the phenomenon three times, each using a different lens. Subsequently, a comparison of the three analyses shows in which dimension a particular populist practice expresses itself most predominantly, and in which dimension less so. This multidimensional approach makes the logical structure revealed in this dissertation useful for political analysis.

One application of this underlying core-structure is developed in this dissertation: the PEP-index, a speech analysis method that defines the political styles of speeches in terms of populism, pluralism, and elitism. Section 3 describes the development of this instrument.

\section{The Analysis Instrument}

In interaction with the development of the political style concept (see Chapter 2), I constructed a political discourse analysis instrument, the PEP-index; the acronym referring to the first letters of Populism, Elitism, and Pluralism. The development of the instrument and the political style concept went hand in hand; new theoretical insights led to alterations in the instrument, while the use of the instrument for actual speech analysis led to further theoretical exploration, which again resulted in alterations in the instrument. After using the instrument for the analysis of 360.000 words - spread over 67 speeches and leading to 32 style profiles of 22 politicians - the instrument has reached its third and current version.

The PEP-index permits the structured political style analysis of political performances, such as speeches and debates, as well as written performances like party manifestos and 
other political expressions. Chapter 3 presents version I of the instrument-with the linear scale positing populism and elitism at the poles of the scale and pluralism in the middle. Chapter 5 presents version 2, in which I substituted the linear scale with a triangular one. Chapter 8 presents version $2+$, in which the instrument is expanded upon with a metaphor analysis tool, used to conduct a metaphor analysis in addition to a style analysis. In the following, I briefly describe its development from the unpublished version 0 to the first published version I, and the current versions 2 and $2+$.

\section{I PEP-index version 0 (unpublished).}

The unpublished version 0 of the instrument discerned only four focus elements (I The people, 2 The elite, 3 Democracy/government, 4 Politics); it did not yet consider the political context (Element 5) as part of political style, but instead as a part of political content. The latter drew on Ankersmit's (1996, p. 28) dichotomy of a mimetic and aesthetic approach to politics, as explained in Chapter 2. Based on the literature, I formulated for each focus element a description of a populist, pluralist, and elitist political style. I integrated the descriptions in a digital analysis instrument, using FilemakerPro software. This software is mostly used to manage databases for marketing purposes. However, it is apt for speech analysis as it is capable of storing large numbers of text and video fragments in a detailed, yet orderly manner that permits general as well as detailed analysis.

In the PEP-index, text fragments can be stored, coded, analyzed, and compared at all elements and dimensions. I developed scripts that automate small tasks, such as adding values to coded text fragments and style elements, collecting speech fragments with one code on one screen, and calculating the average style score of a speech based on sub-scores. The semi-automated environment allows an analyst to assess the political style per subelement, based on assembled fragments in the coded speech which refer to this specific element. After analyzing all sub-elements separately, the average score of the elements displays the political style of a speech. 
Using version 0 , I conducted style analyses of 38 speeches, delivered by twenty Dutch politicians in 1946, I97I, 1994, and 2012 (Appendix A, speeches no 29-67)'. The analysis of 200.000 words in total (average speech length: 5200 words), resulted in the political style profiles of 20 politicians. Together, these profiles demonstrated a meaningful representation of the post-WWII Dutch political landscape; politicians from parties that the literature generally portrays as populist ended up at the populist end of the scale (PVV, SP, BP). Additionally, mainstream politicians in 1946 and 1994 were assessed as less populist than mainstream politicians in $197 \mathrm{I}$ and 2012 (see Figure I.I); this was also according to expectations as the Dutch political climate in the '70s and after 2000 is generally characterized as more populist than in the other examined decades (Aerts, 2003; De Liagre Böhl, 20I3; Den Hollander, 2000; Koenis, 20I4; Te Velde, 20I0).

Although the style profiles generally made sense, the instrument had demonstrated a shortcoming in its use. It regarded the political context not as part of style but of content; however, fragments referring to the context appeared stylized. For instance, in a parliamentary debate in 2012, the differences between Dutch prime-minister Mark Rutte (Speech 29) and his populist opponent Geert Wilders (Speech 59) were clearly a matter of style. Both politicians described the same political crisis, the difference being that Wilders exaggerated this crisis, whereas Rutte provided a positive perspective on it by emphasizing that economic circumstances are always fluctuating and that the measures taken by the government would "help to make the Netherlands stronger." Wilders, on the other hand, overstated the crisis and personally blamed the Dutch prime minister for everything that had been going wrong in the Netherlands. These speech fragments stylized the political context as much as they stylized the element of the political elite.

The literature confirmed the need to include political context as an element of political style; for instance, Moffitt acknowledged the performance of "crisis" as a feature of populism (Moffitt, 2015). As further indication, social identity theory has defied the distinction between content and style centered politics (see Chapter 2). Although adding political context as a fifth style element only defines twenty percent of a political style, Chapter 7 shows that it can make a difference: Boris Johnson's more populist style during the Brexit campaign in 2016 can be largely attributed to this fifth style element. Additionally, Trump's style change described in Chapter 7-from populism to elitism-began with 
changes in his depiction of the political context. In order to assess the precise role of the five elements, the PEP-index saves the attributed styles of both the five elements and the three dimensions separately. In the long run, after having analyzed a cumulating amount of speeches, it will be possible to assess the distinctive roles of the elements and dimensions in both political style in general, and in specific styles such as populism.

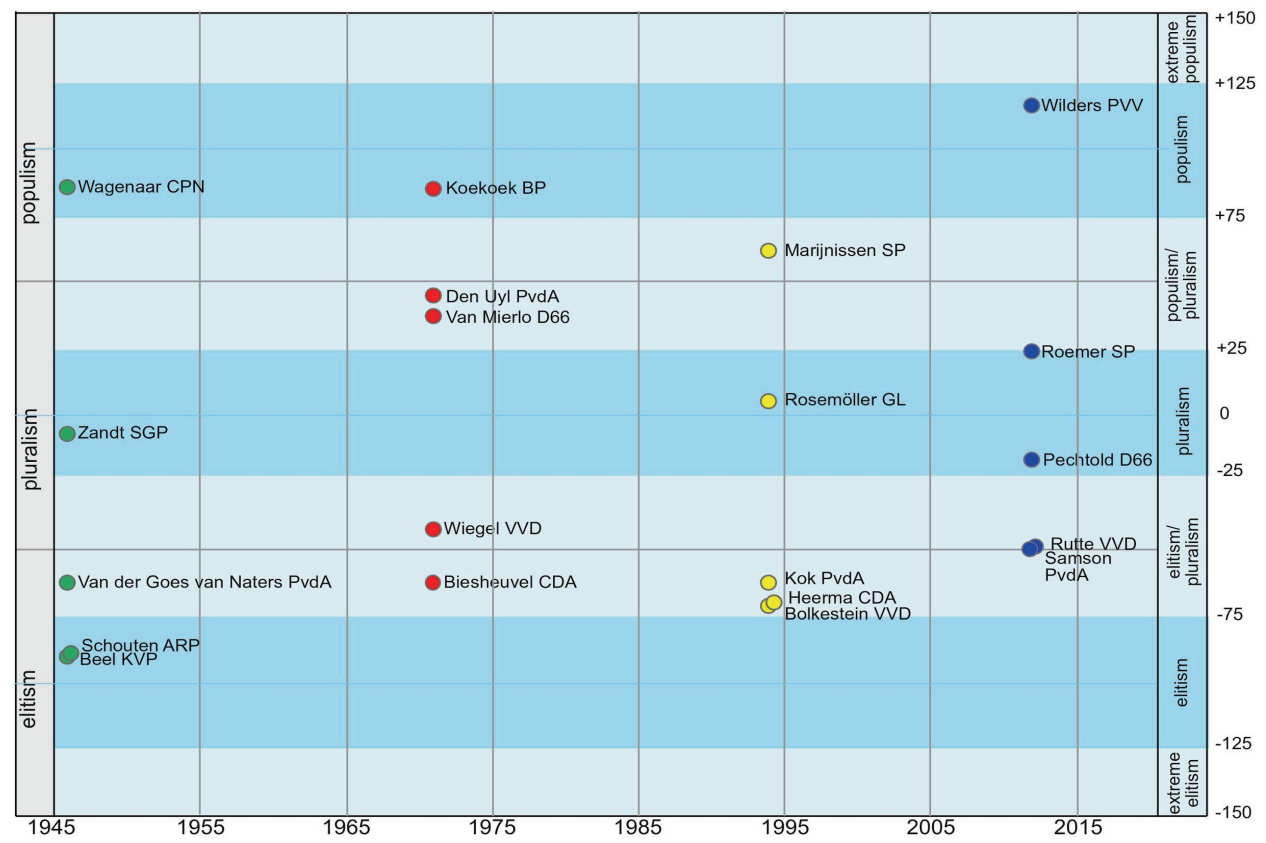

Figure I.I The political styles of twenty Dutch politicians between 1946 and 2012, analyzed with PEP-index version 0.

\subsection{PEP-index version I.}

From the interaction between the actual use of the instrument and the theoretical development of the political style concept, a new version of the PEP-index emerged. Version I not only differed from version 0 in including a fifth focus element; but it also granted the three dimensions more theoretical ground. During initial speech analysis three dimensions had naturally arisen, as it appeared that the same style expressed itself in distinct ways within one element. For instance, the people can be expressed as an idea (good/bad, one/ divided etc.), or as a social position, by expressing to be part of the people or not. While analyzing, I had made a provisory division of the dimensions into value, position, and communication. 
Practically, this categorization worked well; however, it lacked a theoretical ground. Van Dijk's three dimensions of ideology provided this theoretical base (see Chapter 2, and Van Dijk, 1998). The three dimensions differed in detail, which resulted in changes in the instrument.

By 2016, when I had reached this stage in my research, current political events urged me to shift my focus to timelier issues, and away from the longitudinal research of the political style in the Netherlands as of 1945. Instigated by the political success of Donald Trump, I used PEP-index I to assess the political styles of three American candidates in the primaries of 2016 (Trump, Clinton, and Sanders), as described in Chapter 3. The article, published in August 2017, assessed the political style of Trump as populist, of Sanders as mixed populist-pluralist, and of Clinton as mixed pluralist-elitist. Academics welcomed the article as a useful contribution to various topics: such as the analysis of American politics (Norris \& Inglehart, 2019, p. 80), the academic discussion on differences between mainstream, right-wing, and left-wing populism (Ekström, Patrona, \& Thornborrow, 2018, p. 3; Font, Graziano, \& Tsakatika, 2019, p. 17; Miró, 2019, p. 12), and the definition of political style (Crosby, 2019, p. 3; Van Krieken, 20I8, pp. I32, I52, 23I).

\subsection{PEP-index version 2.}

After the publication of version I, the instrument progressed further. Smaller changes occurred in the names of the labels in order to better fit with the updated content. For instance, the second element, politicians, was changed into political elite to better fit with social field theory (see Chapter 2, section 5.2). The ideological dimension changed into ideational dimension, so as to align with the same change in the populism literature (c.f, Mudde, 2004, 2017). For clarity reasons, the communication dimension changed into presentational dimension. These alterations concerned only the names of the labels, not the instrument.

A more radical change was the implementation of the triangular scale, following the logic of the three dimensions (see Chapter 2). Version 0 and I differentiated, on a linear scale, between extreme populism, populism, mixed populism-pluralism, pluralism, mixed pluralism-elitism, elitism, and extreme elitism (as in Figure I.I). As mentioned in the published article (Chapter 3), it did not contain a mixed populist-elitist style. Because the 
analyzed styles of Clinton, Trump, and Sanders did not concern the populist-elitist style, it had not affected those analyses; however, the combination of these two styles does exist.

For instance, the late Dutch politician Pim Fortuyn was famous for spreading a populist message while flaunting his (former) professor-title, being well dressed, and driving a Daimler. Another populist-elitist style mix was visible in a speech of the Orthodox Reverend and parliamentarian Pieter Zandt in 1946 (see Figure I.I). However, whereas Zandt's style can be interpreted as pluralist, Fortuyn's pluralism is more contested. Although his style certainly had pluralist aspects — for instance, his defense of gay rights - it also had antipluralist aspects, such as his critique of the minority rights of immigrants. I reasoned that Fortuyn's mixed populist-elitist style could be understood as a sub-style of pluralism because, in principle, pluralism includes all democratic practices (Blokland, 20I I, p. 2). If populism could express itself in different ways, as explained in section 2, why not pluralism? This explanation, however, did not entirely satisfy. In order to gain a better understanding of the mixed populist-elitist style, I analyzed the concepts of populism and elitism-as well as various other opposing concepts-with the help of the semiotic square of A.J. Greimas (1970/1987). This semiotic analysis (see Chapter 4, and abbreviated in 5, 6 and 8) turned out to be extremely insightful. It improved the instrument in three ways.

First and foremost, it changed the core of the analysis instrument into a strictly logical constellation of opposing concepts, which neatly distinguishes what a style is, and what it is not. With this, it meets with Sartori's requirements of unambiguous categories, yet it does not oversimplify matters, which often happens in the construction of yes/no categories (Sartori, 1970, 1991).

Second, it gave room to a separate anti-pluralist (mixed elitist-populist) style, which solved the problem of opposite styled politicians falling in the same, pluralist category, such as Pieter Zandt and Pim Fortuyn; the conversion into a triangular scale clearly delineates between pluralist styles and anti-pluralist styles.

Third, the semiotic analysis showed that the three dimensions of political style were much more entangled than initially thought, which simplified the double-layered structure of political style. Version I (see Chapter 3) acknowledged three parts of political style that all encompassed three dimensions. The semiotic analysis led to the merging of the two layers; there are no separate three-dimensional styles that cooperate; political style is just one undividable knot of three, sometimes cooperating and sometimes conflicting, dimensions. 
In PEP-index 2, the analyst assigns codes to text fragments based on the description of ninety features divided over six styles, as depicted in appendix D. This is the core of the instrument. All features are related to each other, following the logic explained in section 2 and the next chapter. As an example, the Venn-diagram in Figure I.2 demonstrates how the various interrelated features work in the element of the people.

In Figure 1.2, every feature is a direct contradiction of the same feature of the opposing style (arrow), as well as being a mix of the two adjacent styles. For instance, the pluralist ideational feature of the people is a heterogeneous people. This is opposed to the anti-pluralist feature of a non-heterogeneous people, which is precisely its negation. At the same time, the Venn-diagram shows that this anti-pluralist feature is a shared feature of populism and elitism; therefore, a fragment of political discourse is either populist, or elitist, or a mix of both-at one element and one dimension.

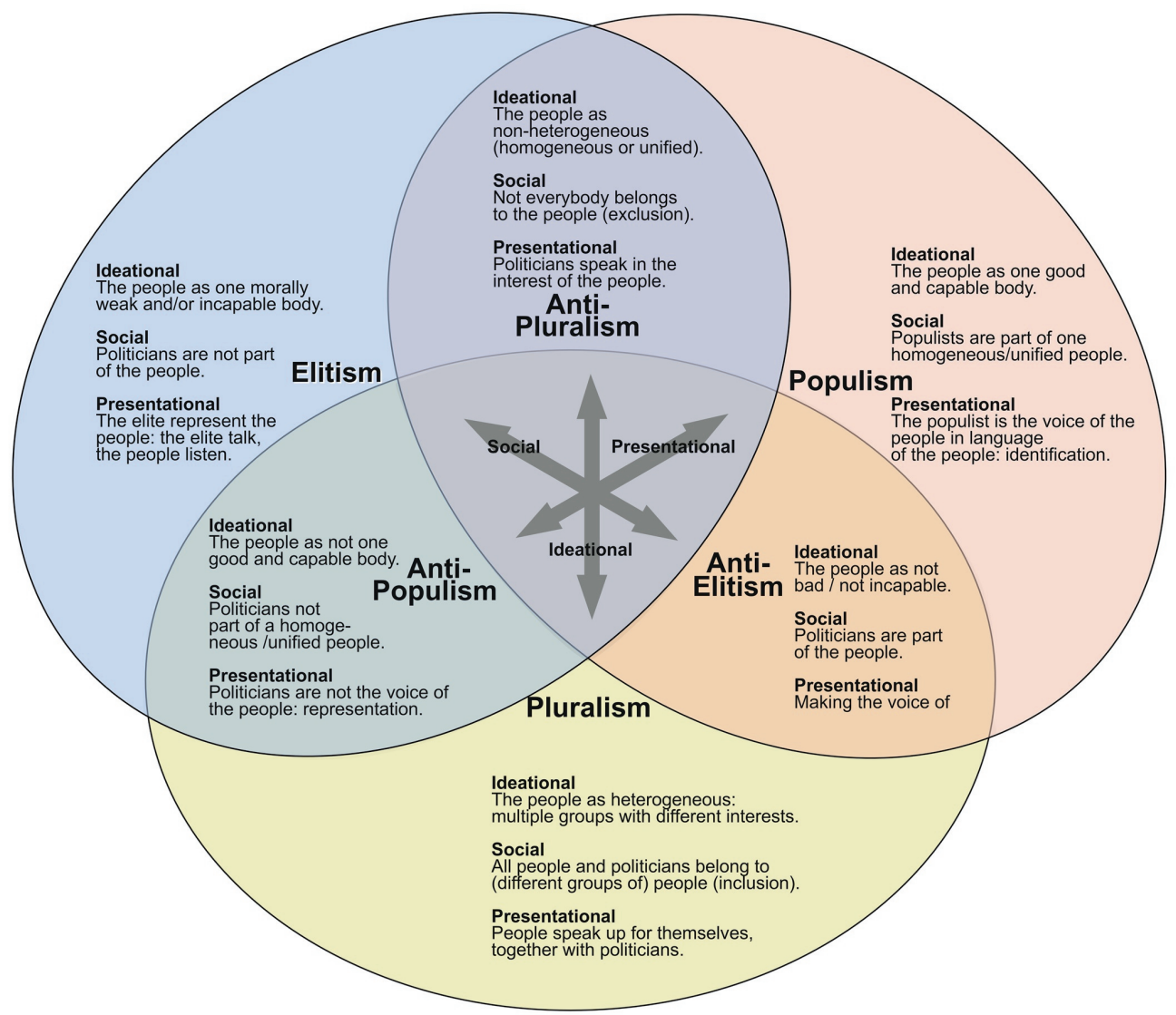

Figure I.2 A Venn-diagram of populist, elitist, and pluralist features, at one element. 
political styles of version 0 (Rutte 2012 and Zandt 1946), that feature in Chapter 4 and 6. The speeches analyzed in version 2 are plotted on a triangular field in Figure I.4.

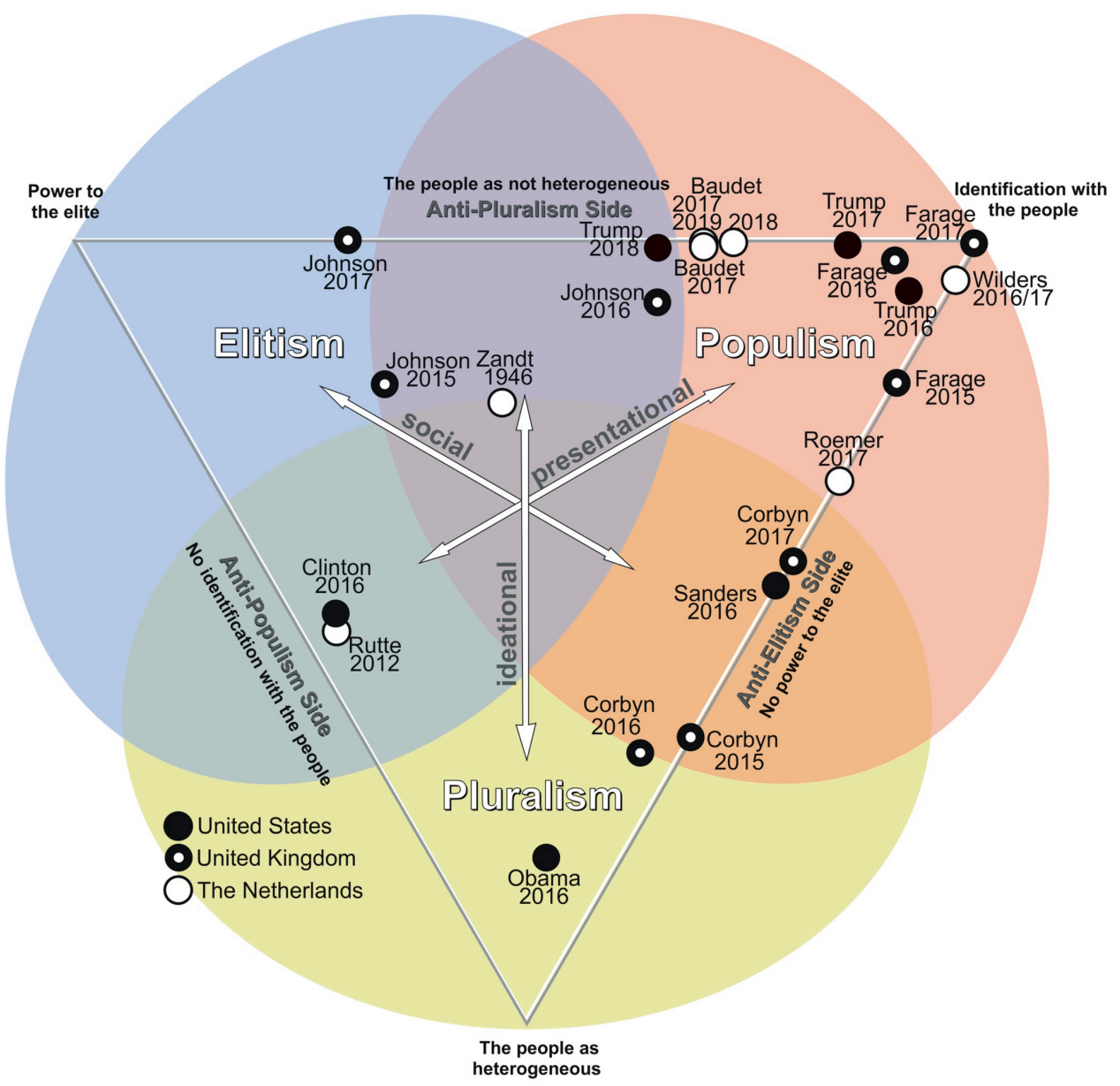

Figure I.4 Political styles of three political contexts (the US, the UK, and the Netherlands) analyzed in the PEP-index 2.

The speech analyses depicted in Figure 1.4 are analyzed in different chapters in various constellations. Chapter 5 , which is devoted to differences within the populist spectrum, compares the speech analyses of Trump 2016, Sanders 2016, and Obama in 2016. These speeches are contrasted with the UK populist styles of Johnson 2016-2017, Farage 20162017, and Corbyn 2016-2017, and the Dutch styles of Wilders 2016-2017, Roemer 2017, and Baudet 2017. Chapter 6-which focuses on the mixed populist-elitist stylecomplements Trump's 2016 speech analysis with analyses of speeches delivered in 2017 and 
2018. It compares Trump's style developed over three years with Boris Johnson's styles over 2015-2016-2017, and Thierry Baudet's styles in 2017-2018-2019, focusing on the differences between politicians as well as changes in the political style of one politician over time. An analysis not part of this dissertation is presented at the PSA conference 2019 in Nottingham. It compares Boris Johnson's political style with that of Nigel Farage and Jeremy Corbyn in 2015,2016 , and 2017. Of each politician, speeches delivered before, during, and after the Brexit campaign were analyzed and compared.

\subsection{PEP-index version 2+}

In order to accommodate secondary analyses on the assessed political styles, I extended the PEP-index with a metaphor analysis tool $(+)$. Based on the metaphor theory explained in Chapters 7 and 8 , the tool facilitates the identification and analysis of metaphors in political discourse. Metaphors can be identified and categorized by their target domain; the part of the metaphor that refers to what is signified ${ }^{2}$. First, all metaphors referring to the five elements of political style can be identified, after which PEP-index 2+ sorts the text fragments containing these metaphors. For instance, all metaphors that are used to signify the people are collected for comparison. This way, links between metaphor usage and political style can be revealed. This extension of the instrument has been used for the analysis in Chapter 8. He re, one populist speech (of Geert Wilders), one pluralist speech (of Barack Obama), and one elitist speech (of Boris Johnson) are compared on metaphor usage.

\section{Outline of the Dissertation}

This dissertation consists of a collection of six articles on the joint topic of political style, complemented with an introductory chapter, a theoretical chapter, and a conclusion. The chapters 3, 4, 6, and 7 have been published in peer-reviewed academic journals in the interdisciplinary field of politics and discourse; Discourse and Society (Sage), Critical Discourse Studies (Taylor \& Francis), Populism (Brill), and Metaphor and the Social World (John Benjamins). Chapter 5 and 8 are published or accepted as book chapters in peer-

\footnotetext{
2 F.i. In 'Eleonore is the sun', the 'sun' is the source domain and 'Eleonore' the target domain of the metaphor. See also Chapters 7 and 8.
} 
reviewed edited volumes, for which I was invited to submit a chapter after presenting conference papers at international conferences (Palgrave and Ediciones Universidad De

Navarra). Figure 1.5 depicts the relation of the separate chapters to each other.

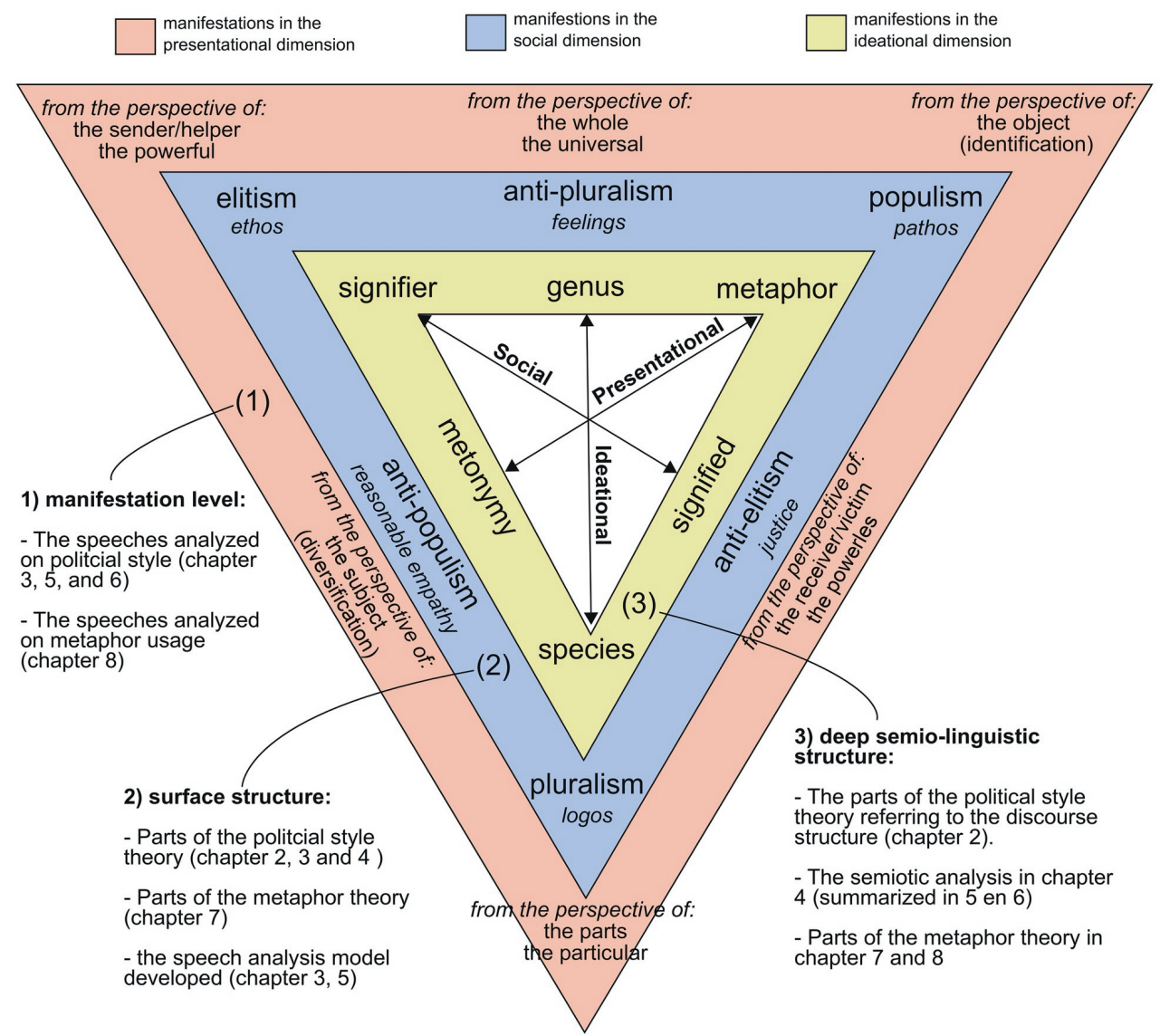

Figure I.5 The relation between the chapters in this dissertation and the three levels of discourse in which political style manifests itself. 
As a collection of articles, parts of the chapters inevitably overlap. Overlap is particularly present in the description of the developed analysis instrument and the core structure underlying populism. However, this drawback does not outweigh the advantages of broader dissemination and the possibility to read each chapter separately. Chapter 4 is especially dense and may be difficult to follow for anyone not specialized in semiotics. Summarized versions of this analysis are provided in other chapters, which should satisfy readers more interested in the speeches analyzed than in the underlying theory. In addition to Figure I.5 that connects the chapters in a graphic, in the following, I briefly describe the topics of the subsequent chapters and how they relate to one another:

- Chapter I introduces the main topic of this dissertation and describes the development of the political style analysis instrument. It also demonstrates the relationship between the independent chapters.

- Chapter 2 presents a theoretical chapter on political style; it serves to bring together the dissertation's theoretical foundation that is scattered over the separately published chapters.

- Chapter3, published in the journal Discourse \& Society, disentangles political style as consisting of three dimensions and five elements. Based on this analysis, it presents version I of the developed analysis instrument for political style. As an example, a style analysis of six speeches of US politicians-Donald Trump, Bernie Sanders, and Hillary Clinton-is conducted.

- Chapter 4, published in the journal Critical Discourse Studies, investigates the precise relationship between the populist, elitist, and pluralist political styles. The investigation brings together different approaches to populism by connecting them through one shared underlying structure. The semiotic analysis reveals that the meaning of populism is locked in a three-dimensional opposition of elitism and pluralism. This is useful for political analysis, as the three concepts together precisely demarcate if parts of political discourse are populist, elitist, pluralist, or a mix of two styles.

- Chapter 5, to be published as Chapter 14 in the edited volume The Return of Populists and the People (in press), presents version 2 of the analysis instrument developed, the PEP-index 2. The new version integrates the triangular structure of Chapter 4, connecting populism, elitism, and pluralism in a three-dimensional opposition. Subsequently, it applies it to the analysis of political speeches of nine American, 
British, and Dutch politicians, focusing on style differences within the populist spectrum.

- Chapter 6, published in the journal Populism, clarifies how elitist elements are integrated into populist discourse by analyzing political speeches that make use of this incongruent style. Speeches by Donald Trump (US), Boris Johnson (UK), and Thierry Baudet $(\mathrm{NL})$ are analyzed and compared. The populism-elitism mix is easily combined with nationalism. Its political significance justifies thoughtful academic consideration for the populist-elitist mix, alongside the ample attention for full populism.

- Chapter 7, published in the journal Metaphor and the Social World, focuses on the theory of political metaphor as one expression of political style. Based on classical rhetoric and contemporary metaphor theory, the following three main purposes of metaphors in political style are discerned: reason-based, emotion-based, and strategybased usage of (conceptual) metaphor.

- Chapter 8, published as Chapter 4 in the edited volume Metaphor in political conflict. Populism and discourse, presents a comparative metaphor analysis of three speeches, each with a different political style; one populist speech, one elitist, and one pluralist speech. The goal is to clarify differences in the metaphors by relating them to the political style of the speeches.

- Chapter 9 discusses the overall conclusions against the background of the academic literature on the topic. It establishes the contribution of this dissertation to the academic literature and recognizes the need for further investigation. 


\section{2 \\ Political Style Theory}

Because We Never Go Out of Style

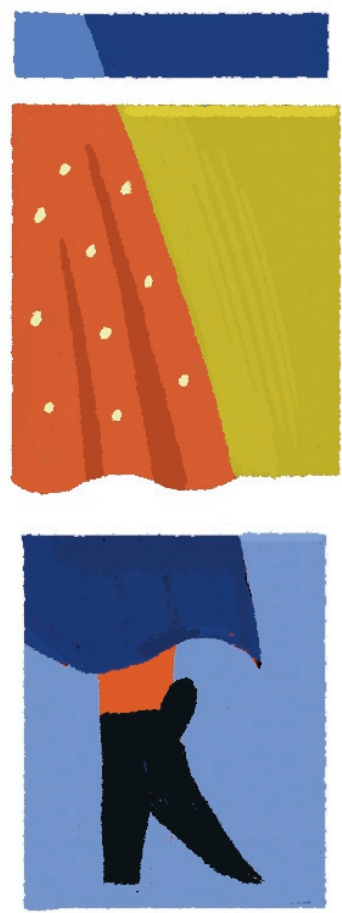


Cause we never go out of style.

We never go out of style.

Taylor Swift, Style.

\begin{abstract}
This chapter presents a theoretical foundation of political style. It summarizes the theoretical paragraphs that are scattered over the separately published chapters 3 to 8 , and supplements it with parts that were omitted due to the word limitations of the host books and journals. Political style is defined as a three-dimensional political performance generating political meaning. In today's mediated political environment, it not only matters what a politician says (ideational dimension). More than ever, it matters how it is expressed (presentational dimension), and what a politician does (social dimension).
\end{abstract}

\title{
I Introduction
}

The stylization of political communication has been at the core of politics since antiquity. It predominantly has served the purpose of engaging people in politics. In order to conceptualize the entertaining aspect of politics, scholars often depict it as a theatre play or spectacle (e.g., Edelman, 1988; Green, 2010; Manin, 1997). Voters are seen as the audience of the political play, whose role is to "gaze" at and judge the performance of politicians. This judgment primarily concerns serious political matters; where it addresses political style, it judges the trustworthiness and capability of politicians, rather than the level of entertainment. The latter is seldom seen as a requisite for good government; on the contrary, since Antique Rome, politicians with an abundant ornamental style have been assumed to be frauds. A sober style is usually understood as more trustworthy, although the use of a pathetic style - based on pathos rather than logos or ethos-is sometimes deemed necessary; for instance, in matters of grave importance, or in order to gain the support of the mob (Cicero, trans. 2013; Kennedy, 1999).

Currently, however, the sober style has fallen out of fashion. Politics has never been more entertaining since the installment of Donald Trump and Boris Johnson as political leaders in the US and the UK. Although the soundness of their political strategies is highly contested, and they are both frequently exposed as liars, their popular support remains 
broad. In a New York Times article on Trump supporters, entertainment is even shown as a purpose of politics: "Most of his supporters say they will stick with him, citing his blunt style, which some of them see as a form of entertainment" (Tackett, 2019). In this quote, media logic (entertainment) has taken over political logic in the judgment of politicians.

Another example in which media logic profoundly impacts current politics follows from the recorded nature of political performances. Old performances are easily recollected, which allows for apparently contradicting ideas, expressed a long time ago, to be quickly shared on social media. In the fragmented nature of new media, good reasons for difficult decisions and compromises are easily lost. For instance, in the race for the nomination of the 2020 Democratic US presidential candidate, older, moderate politicians such as Joe Biden are being accused of previously having acted in contradiction to their current standpoints (Hook, 2019). Fragments of contradictory performances are forwarded out of context (e.g., Flamingo999, 2019); which leaves an image of inconsistency and unreliability. In a media logic, compromises are generally ill-advised because they always contradict one's carefully constructed political identity to some degree. Hence, the current polarized political climate is - at least partly —a matter of media logic taking over political logic, and thereby restricting politicians to performances that are easily understood and contribute to a coherent, long-lasting political identity.

The above-outlined political developments illustrate that it is vital to analyze the political styles of politicians in order to understand contemporary, media-guided politics. However, up till now, the concept of political style has remained under-developed. Illustrative of this lack is the academic discussion on whether populism is to be seen as a political style or something else, such as an ideology or political strategy. In this discussion, style is sometimes equated with rhetoric, sometimes with discourse, language, performance, or with solution style (e.g., Canovan, 2002; Hawkins, 2009; Kazin, 1995; Koenis, 20I4; Moffitt \& Tormey, 2014). Some scholars mainly use political style in opposition to political ideas (e.g., Taggart, 2004), and others assemble all approaches to style under the umbrella term discourse (Gidron \& Bonikowski, 20I3; Kaltwasser, Taggart, Ochoa Espejo, \& Ostiguy, 2017). However, performance differs from language, and different discourse approaches highlight different aspects of populism. This impreciseness obscures the discussion and obstructs a consensus on the nature of populism.

In order to structure the discussion on political style, this dissertation starts with an in-depth analysis of the political style concept. It draws on notions of political style 
developed in democratic theory and representation (Ankersmit, 1996, 2003; De Haan, 2000; Koenis, 2014; Laclau, 2005a; Laclau \& Zac, 1994; Pels, 2003a; Pels \& Te Velde, 2000) as well as theories on social style and identity that originate in sociology and discourse studies (Butler, 1988; Giddens, 199I; Goffman, 1956; Wodak, 2009). Rhetorical notions of political style are also considered (Cicero, trans. 2013; Hariman, 1995; Quintilian, trans. 2002). Theories on ideology and ideological discourse are studied in order to demarcate the difference between political style and ideology (Althusser, 1971/2008; Freeden, 1996, 2003; Gouldner, 1976; Thompson, 1990; Van Dijk, 1998, 2015). Based on these theories, the following definition of political style is formulated. The first part is a general definition, for which the second and third parts give specifics:

I Political style is the stylized performance of political agents (politicians, parties, and alike) on the political front stage, aimed at filling the aesthetic referential gap between the voter and the representative with a political identity.

2 This performance is conceptualized as a tag cloud of ideological fragments of text, talk, image, sound, and action. Rather than ideological theory, the identity of the performer is responsible for the coherence of their political style.

3 Political style encompasses three dimensions, in which different aspects of style are expressed. Political agents use these three dimensions in distinctive combinations, assembling their own unique political identity. The three dimensions are:

- The ideational dimension (cognition, ideas);

- The social dimension (group membership and relations), and;

- The presentational dimension (rhetoric and communication).

Sections 2 and 3 of this theoretical chapter explain the first two parts of this definition. In sections 4 and 5, I explain the third part: the relation of political style with the three dimensions of discourse. In section 6, I present five focus elements for style analysis. Section 7 discusses the style labels that best fit with these elements: populism, elitism, and pluralism. Finally, section 8 explains the role of metaphor in political style, a key feature of political style. Overall, this theoretical chapter collects and rearranges the fragmented presentations of the underlying theory in this dissertation, and supplements it with parts that were omitted due to the word limitations of the host books and journals. 


\section{Political Style as Performance}

The starting point for this dissertation's definition of political style is Ankersmit's notion that politicians are never identical to the people that they represent (Ankersmit, 1996, 2000, 2003). According to Ankersmit, there always is an "aesthetic referential gap" between the voter and the representative (1996, Pp. 49-56). Politicians stylize their performance into a unique political identity in order to connect with their own group of people. Ankersmit differentiates between a "mimetic" and "aesthetic" approach to democracy (Ankersmit, 1996, p. 28). A mimetic representation does not recognize the gap between the voter and the politician; it focuses solely on political content. This neglect places a mimetic approach fundamentally at odds with the representative nature of modern democracies. An aesthetic approach, on the other hand, recognizes the gap and acknowledges that politicians stylize their performances as representatives.

As Pels and Te Velde exemplify, the current mediated political landscape encourages more stylized political performances (Pels, 2003a; Pels \& Te Velde, 2000). Pels embraces stylized politics, seeing it as an advantage in an age where politics has become the profession of experts. According to Pels, there is no need for the people to understand all the policy details, as they can judge politicians based on a shared style and taste (Pels, 2003a, p. 50).

The notion of the aesthetic referential gap is valuable. However, the difference between a mimetic and aesthetic approach to democracy-or between content-centered and stylized politics - holds only in theory. Ankersmit admits that a mimetic approach to democracy is also a style: one that presents itself as intentionally style-less (Ankersmit, 2000, p. 35).

Ankersmit's notion of the aesthetic gap reminds of Laclau's notion of political identity. Laclau sees, like Ankersmit, a "gap" between political identities and the people that express them. Laclau states that it is not only democracy that is representative, but all subjects as well. Laclau refers to Lacan's theory of the split subject: the representational gap exists at the source of every (political) demand because an identity is never the same as the actual person. In Laclau's vision, the institutionalist way of structuring society is as much a construction (or a style) as the populist view of the people (Laclau, 2005a, Pp. 80-8I; Laclau \& Zac, 1994).

Laclau's ideas closely align with social identity theories such as Butler's, Goffman's, and Giddens' (Butler, 1988; Giddens, 1991; Goffman, 1956). In these approaches to identity, 
all humans "perform" their identities on the front stage of social life. In doing so, they create their identity in interaction with their surroundings. As a political identity is not principally different from any other form of identity, every political performance is creatively stylized. Hence, all politicians have political styles on which they can be assessed through a study of their performance. Ankersmit's mimetic style and the Laclau's institutionalist style can be seen as anti-styles, similar to the sober Attic style of Cicero (Cicero, trans. 2012), mentioned in the previous section.

Seeing political style as performance is nothing new; Aristotle and Quintilian-in their rhetorical treatises - elaborately addressed the performance aspects of delivering a speech, mostly by giving directions on how to improve such performances (Aristotle, trans. 1984; Quintilian, trans. 2002). Over the centuries, the focal point of rhetoric has shifted to solely its linguistic aspects. In accordance with this, contemporary scholars concerned with political style have focused mostly on language (e.g., Hariman, 1995; Kazin, 1995). Recently, however, Moffitt and Tormey proposed to define populism as a political style in the sense of a performance (Moffitt, 2016; Moffitt \& Tormey, 20I4). Their general definition of political style has some similarities with the definition in this dissertation but differs substantially in terms of details. These differences are mainly a result of focus; whereas Moffitt and Tormey focus primarily on populism and secondarily on political style, this dissertation focuses first on political style, and second on populism - the latter being just one of the style labels used.

One advantage of not focusing primarily on populism is the greater distance from the populist phenomenon; a focus on mere populism automatically directs the attention to differences from other styles, whereas a broader focus diverts the attention to similarities as well. This approach turns out to be extremely insightful, as populism is as much defined by its similarities to other styles, as by its differences (see Chapter 4). One important feature that populism shares with other political styles it that it is a group style; as Ankersmit (1996) has noticed, it functions as a bridge between a politician and a group of people. However, a pure group style is utopian, as groups consist of individuals that need systems that reconcile group and individual interests. Populism is just one way of mixing three styles (a group, personal, and systematic style) in one political performance. More on this later; first, I want to address the nature of political style defined as discourse. 


\section{Political Style as Ideological Discourse}

According to semiotic theory, not only language provides meaning, the whole social world does (Chandler, 2002; Greimas \& Parret, 2017). Hence, the entire performance of a politician can be seen as a signifier, signifying a political meaning. Performances that have certain similarities have the same political style, just like books and paintings are written and painted in different styles. Each political style is a specific type of political articulation.

In its discursive nature, political style comes close to Althusser's definition of ideology as discourse. According to Althusser, ideas do not float around immanently from their expressions (Althusser, 197I/2008). Based on Lacan, Althusser argues that the mere recognition of a subject - the person generating ideas-is already an expression of discourse, as the subject emerges from its entrance in the symbolic order that is constituted of discourse (197I/2008, p. 45). Althusser emphasizes the materiality of ideology; ideology is present in what he calls "the Ideological State Apparatus." Althusser's definition of ideology situates it at another level than traditional ideologies; it refers to churches, schools, the family, and political institutions altogether. Ideology manifests itself in the mere existence of those institutions. Althusser admits that those institutions also produce their own, distinct ideologies. He calls the latter "secondary, subordinate, and derivative" of the Ideological State Apparatus. As "by-products," they lose his interest, as he sees them as a "bourgeois tactic of dividing the working class at the level of politics" (Althusser, I97I/20I4, p. 84). He sees these political fights as different from the proletarian fight because the latter aims to destroy the entire bourgeois system, whereas political fights remain within it. In contrast, Laclau and others defy the possibility of a "proletarian fight"; destroying the system would ultimately mean destroying the subject, as the subject exists only within the system (Laclau, 2014; Laclau \& Zac, 1994).

Like Althusser, Laclau sees ideology as discourse. He further focuses on populism, which, in Laclau's definition, broadly equals this dissertation's definition of political style; he defines it as a specific "mode of political articulation" (Laclau, 2005b, p. 37). Laclau specifies this by opposing populism with institutionalism. Populism is on one end of the scale, discursively creating an internal frontier between the powerful and the underdog. On the other end, there is institutionalism, in which there is no internal divide, only individuals and institutions working together to solve problems. This definition recalls Ankersmit's (1996) differentiation between an aesthetic and a mimetic approach to politics. Mimetic politics and 
institutionalism both focus on the content of demands and neglect the fact that these demands are articulated in a certain way. Laclau states that pure institutionalism and pure populism are utopian; all politics are populist to some extent, without further specifying this in terms of styles or types, as done in this dissertation. According to Laclau, the populism concept is inherently vague, and differentiations of it directly refer to various manifestations of populism in the political context (Laclau, 2005b, pp. 45-47). So, Laclau focuses on levels of abstraction that are both one higher and one lower than the level at which this dissertation focuses. In Laclau's theory, there are no styles-just populism as a discursive act, manifesting itself in endless contextual variations.

Although Althusser's and Laclau's explanations of ideology/populism as part of discourse are vital, their theories are not of use in further deciphering political style; they both do not focus on the level of style, even do not recognize it. For this purpose, Van Dijk's multidisciplinary theory on ideology is useful (Van Dijk, 1998). Van Dijk looks at ideology in its socio-psychological function; how do groups emerge and exist. He defines the function of ideology as the cognitive interface between group-action and group discourse (Van Dijk, 1998, pp. 69-70, 2013, p. 178). This definition comes close to Ankersmit's definition of political style as a means of political parties to connect with their own group of voters (Ankersmit, 1996, p. 60). Van Dijk's definition of ideology discerns three dimensions; cognition, group relations, and discourse. According to Van Dijk, the cognitive dimension of ideology works as a grammar of group discourse and action (1998:32, 53-58, 90, 148-50, 199). Just as the grammar of a language does not disappear when the language is not being spoken or written, in the same manner, the cognitive dimension of ideology does not disappear when no one is expressing shared group thinking in discourse or social action: "Indeed, there are languages that, as linguistic systems, have survived their users. Similarly, socialism as an ideology will still be an ideology even when the last socialist has switched off the light." (Van Dijk, 1998, p. 148)

Unlike Althusser and Laclau, who only recognize the materialized expressions of ideology in discourse, Van Dijk grants the cognitive level an immanent dimension in ideology, separate from its expressions in discourse and social action. His choice of labels suggests that cognition and social acts exist outside of discourse, as he labels the categories as cognitive, group, and discourse. However, Van Dijk's comparison of the cognitive level of ideology with the grammar of a language, recalls De Saussure's division of language into two levels: the language system (langue) and language use (parole) (Saussure, 1916/2015). 
Transposing this division onto discourse suggests that the three dimensions of Van Dijk can be understood as

I cognition $>$ the mental discourse system

2 discourse $>$ discourse use

3 group $>$ social action.

This Saussurian interpretation of Van Dijk's three dimensions shows that the three dimensions work well as dimensions of discourse; dimension (I) and (2) relate to each other in the same way as language system relates to language use (Saussure, 1916/2015). The addition of a third dimension differentiates discourse from language. Although all three dimensions are part of discourse, the system ( $\mathrm{I}$ ) cannot be reduced to its expressions ( 2 and 3 ); it explains them at another abstraction level and adheres to its own, systematic, logic, as explained in Chapter 4.

Applying this to my research, I have labeled the mental discourse structure of political style its ideational dimension. The expression of political style in the social world, I labeled the social dimension, and its expressions in actual discourse use, I labeled the presentational dimension of political style. The three dimensions together form the political style of a politician. These labels do not suggest—like Van Dijk's labels - that the cognitive dimension exists outside of discourse; ideas are - in line with Althusser and Laclau-part of discourse as well. Nevertheless, they are operating at a distinct level of discourse, abiding by a different logic than the logic of the other two dimensions.

\section{Three Basic Tensions in Discourse}

Before focusing on the three dimensions within political style, this section better explains the immanent character of the ideational dimension, in order to prevent misunderstandings. Granting ideas an immanent dimension in discourse seems to contend the relative nature of discourse; if ideas are immanent, they seem to refer to a truth that exists outside of discourse. This, however, is not the case, as it is not the content of the ideas that is immanent, but their structure: the ideational dimension can be traced back to one of the three major principles behind signification, as distinguished by De Saussure (for a good explanation of De Saussure, see: Culler, 1976). The connection between the three 
dimensions and these three basic principles of signification shows that all three dimensions are structural and not based on any pre-given content or truth:

I) The ideational dimension traces back to the syntagmatic relation between signifiers. A syntagmatic combination of signifiers categorizes different species as belonging to one genus at a different abstraction level. The relationship between genus and species always contains a tension, as no species (the part) is exactly the same as the genus (the whole), yet all species together constitute the genus, which contains an additional meaning at one abstraction level higher. This excess of meaning provides the grounds on which one can decide which species belongs to a genus and which not. For instance: no specific dog-be it a Saint Bernard or a Chihuahua_precisely fits the linguistic genus of a prototypical dog. Yet, a Chihuahua is undoubtedly a dog and not a rabbit, an understanding based on the excess of meaning generated by the signifier of the genus dog, one abstraction level higher than the different species. The ideational dimension comprises generalizations and categorizations of signifiers that are generally accepted as truths, notwithstanding this truth is not universal, but just one framing in discourse.

2) The social dimension traces back to the opposition of signifier-signified. The relation between the two is arbitrary and, for this reason, purely a matter of power; it is the powerful subject that imposes a signifier on the powerless signified object. Although the meaning of this signifier never suffices - the signifier can never be identical to "the thing"- the signified object has no power to change the meaning imposed by the signifier. An obvious example is the naming of a child by their parents; a child has no power to reject this name. It is not until they become a powerful subject themselves that they can choose to take another name. De Saussure was not interested in this dimension; in his definition, linguistics had the language system as an object of study, not the arbitrary connection between signifier and signified. For the broader study of discourse, however, it is one of the three central principles.

3) The presentational dimension traces back to the paradigmatic relation between signifiers. In discourse use, a paradigmatic relation between signifiers (all possible meanings of one signifier) can be exploited in order to construct a new meaning. This is always the result of a speech act, performed by a subject through language use. In this language use, there is a difference between metaphor and metonymy; whereas metaphor fills the lack of 
signification through the imagination of being the whole / the thing (identification), metonymy bridges the gap by being adjacent to the whole / the thing (approximation).

The difference between the presentational, social, and ideational dimensions is fluid: the three dimensions are circularly related as they constitute each other. All metaphorical/metonymical expressions (presentational dimension) have the potential to end up as a signifier (social dimension) or genus (ideational dimension). For instance, the name Seltzer as a synonym for sparkling water in the US originates in one brand of sparkling water, named after the German village Selzer. The brand name Seltzer has been used as a metonymy for the genus of sparkling water in general; after some time, people forgot that it was a metonymy and started using it as a name for (artificially made) sparkling water. At the moment that Seltzer changed from a metonymy into a genus and a signifier, the logic of Seltzer changed: it was no longer a deliberate speech act, as its name/genus was accepted as logical and natural; there was no comparison with two parts of the metaphor/metonymy, different brands of sparkling water were directly categorized as Seltzer.

The difference between a categorization process and a metaphorical process is significant. Research into the neurological processing of conventional and new metaphors shows that it takes the brain more time to process new metaphors and metonymies than highly conventional ones. For this reason, it is argued that the two are processed differently in the human brain; the former process is based on comparison, the latter on categorization (Bowdle \& Gentner, 2005). This bolsters the argument that the ideational dimension, in which categorization is pivotal, works according to its own logic; it uses a different neurological process than the metaphorical process, in which an active comparison is involved. The question of as to whether an expression is ideational-based on categorization - or presentational — based on comparison - is difficult to answer and can vary from utterance to utterance. However, undoubtedly, the two logics are different.

The ideational logic originates in the tension between the whole and its parts. As said, this formal logic of categorization does not consist of an immanent set of truths that exist outside of discourse. Its placement outside action and time in the discourse system is only partial, as the dominant framings in the ideational dimension were once constructed through discourse use, such as in the case of Seltzer. This process can be reversed: the moment that the logic behind apparent obvious truths is revealed as framing instead of truth, the system opens up for change. 
An example of such a change from obvious truth back to framing is gender, as has been put forward by Judith Butler (1988, 1993). For a long time, gender was just a matter of truth: you were either a man or a woman, which was seen as a biological fact. Gender was a matter of categorization and part of the discourse system rather than of discourse use. Today, however, gender has become more fluid, and a matter of discourse use instead of system. This is a long process because framings are resilient (for an interesting case study into frame changing on the death penalty, see: Baumgartner, Linn, \& Boydstun, 2010). The structural anchoring of framings in the ideational dimension makes it difficult to change these meanings, as these anchors restrict the discourse use to begin with. However, by making framings visible, it is possible to change the discourse system: discourse is not static, not even in the ideational dimension.

What never changes, however, is that the ideational dimension adheres to its own logic - a systematic logic of categories and generalizations-which partly contradicts the logic of the other two dimensions: these other two dimensions are not organized around the tension between the whole and its parts, but around the tension between the name and the thing, and between identification (through metaphor) and approximation (through metonymy), respectively. The three discourse dimensions cannot be separated, nor can they be reduced to each other. They construct each other, but also have an excess of meaning in each dimension, as demonstrated in Chapter 4. It is precisely within this excess of meaning that the dimensions contradict one another. Confronted with each other, however, they reveal that they are but framings, not truths, resulting in an opening and the possibility to change the dominant framings in the ideational dimension.

\section{The Three Dimensions of Political Style}

This section specifies how the three discourse dimensions work in political style. The first part of political style, the ideational dimension, concerns the-intentional or unintentional-expression of ideas: generalizations and categorizations that are presented as truths. They can be conceptualized as a tag-cloud of idea fragments. Ideational style differs from a traditional ideology in its fragmented nature, combining verbal, visual, and auditory elements; there is no strong internal coherence necessary, as the other two parts of a politician's political style - the social and presentational parts-hold the style together. Vice versa, the ideational dimension is the interface between the social and presentational parts 
of political style; it functions as the ideological grammar that guides actual group actions and expressions in language. Although the ideational part of political style depends for its expression on the social and presentational part, it cannot be reduced to these parts alone; the ideational part not only explains the other two styles at an abstracter level. It uses the logic of categorization and generalization, resulting in dominant framings in a society, and is the basis of common sense.

Second, the social dimension of political style involves the construction of identities; the adoption of a signifier by a subject. This goes beyond the "arbitrary" relation between signifier and signified, that lies beneath this dimension. Although the adoption of an identity/name is, from a linguistic perspective, free, the social world is also discourse and restricted by the discourse system. According to Butler, a social style is not an expression of a stable self; instead, "identity itself is instituted through a stylized repetition of acts" (I988, p. 519). People do not freely choose these acts because societal discourses and conventions restrict them. It follows, then, that the social identities of politicians are constrained by what voters accept as fitting. Consequently, politicians sway toward political styles that profile them as fit for the role of leader of the country, mostly tapping into stereotypical elite identities.

Besides their self-identities or social roles, people also have group-identities; an idea explored by social psychologists Henry Tajfel and John Turner. Group-identities derive from the knowledge of being a member of a social group, and an emotional attachment to that membership (Ellemers \& Haslam, 2012; Turner \& Reynolds, 20I2). A social group style is used to show allegiance with specific groups in society, take a position on the political field, and connect the individual with people who share the same ideas. For instance, socialists, communists, but also populists, typically profile themselves as part of the common people by using a specific language, dialect, or clothing style. For instance, in the Netherlands, the former president of the Social Democratic Party, Hans Spekman, always wore jeans and sweaters instead of a suit, so as to express that he was a commoner.

With the help of laboratory experiments, Tajfel and Turner revealed multiple group processes, which lead to Social Identity Theory (SIT) and Self-Categorization Theory (SCT). For instance, the fact that one belongs to a group (white or black, American or British, etcetera) already has the effect of favoring in-group members over outgroup members (Turner \& Reynolds, 2012, p. II). Also, experiments suggest that the more a leader looks like a prototype of their own group, the more in-group members will see them as 
charismatic (Turner \& Reynolds, 2012, p. II). For political style, it follows that there are electoral benefits to stylizing one's political identity as belonging to a large, dominant group. These insights into social style demonstrate the usefulness of distinguishing group identities (group style) from self-identities/social roles (individual social style). These are two different functions of the social dimension of political style, which politicians can use differently.

The third part of political style is the presentational dimension, which involves the rhetorical presentation and the persuasion function of political communication. Traditionally, this part is equivalent to political style; it puts the focus on style mainly as language and means of persuasion (e.g., Hariman, 1995; Kazin, 1995). Rhetorical persuasion, however, is just one of the three functions of political style; for instance, division-forcing people to choose for either us or them-is just as much a purpose. This is demonstrated by ISIS's online publications of beheading videos, which are evident examples of political communication, hence, political style (Chouliaraki \& Kissas, 2018). However, the videos were only persuasive for those who already believed in the ISIS cause; for all other people, they were extremely repulsive, even a severe threat. The polarization effect of the videos was not primarily a presentational (rhetorical) matter, but a social one; seeking connection with ISIS' own group of people, in order to recruit new fighters. Its rhetorical and ideational function is mainly subservient to its social purpose.

Nevertheless, the presentational dimension is crucial in political style because it is in this dimension where changes in the other two dimensions begin. Through creatively using language, dominant framings can be revealed as (metaphorical) framings instead of truths. This can be the start of a revolt in the social dimension of the powerless against the powerful. And, ultimately, it can lead in the establishment of new dominant framings forming a "hegemony" (Laclau \& Mouffe, 1985) in the ideational dimension.

\section{Five Focus Elements of Political Style}

The systematic analysis of political style gains insight from its division into three dimensions, but this division is still not specific enough to guarantee an equivalent analysis of various performances. To be able to analyze political style comparably, the attention in all analyses must be directed towards the same elements. To decide which elements cover political style best, the specific manifestations in the different dimensions is analyzed. As the ideational dimension is only accessible through its manifestations within the other two dimensions, it 
suffices to analyze how political style manifests itself in discourse use (presentational dimension) and social action (social dimension). Both analyses result in broadly the same five elements, as explained below.

\section{I Focus elements in the presentational dimension.}

As politicians construct their political identity in interaction with their surroundings, elements of political style can be formulated in terms of those surroundings. In order to discern the surroundings in the presentational dimension, the theatre concept is useful. It depicts politicians as actors or movie stars, who compete with each other for the attention and approval of the audience- -the audience representing the voters and the media. The play that the actors perform is called democracy. The stage represents the socio-historical context: the country, available technology, and historical events. The roles of the actors differ: they can be a parliamentarian, member of the government, or part of a social movement. Traditional ideologies offer the script, but actors can also choose to improvise their performance or draw from multiple scripts of different ideologies. Without mandatory scripts or directions, all actors produce their own performance; this is their political style.

As more elaborately described in Chapter 3, the analysis shows that the political stage contains five discursive elements on which politicians can express their political identity as unique, apart from their political standpoints (the political content):

I The people,

2 Politicians,

3 Democracy/government,

4 Politics, and

5 The political context as a whole.

For instance, politicians can speak about the people or the elite (elements I and 2) as a homogeneous or a heterogeneous group, as good or bad, competent or incompetent. They can present the government or democracy (Element 3) as corrupt or fair, fake or respectable. Politicians can speak about politics (Element 4) as a fight, or as cooperation. They can also proclaim that the political context as a whole (Element 5 ) is in crisis or in 
progress. In sum, these five elements cover political style in the presentational dimension and can function as focal points in political style analysis.

\subsection{Focus elements in the social dimension.}

For analyzing the social dimension of political style, the field theory of Fligstein and McAdam is helpful (2012). Bonikowski and Gidron (2016) pointed at the aptness of this theory for populism by showing that incumbent US presidential candidates used fewer populist elements in their speeches than did challenging candidates. A closer look at the theory reveals that it explains the social part of political style very well.

The political field in which politicians operate can be viewed as a strategic action field, defined by Fligstein and McAdam as "socially constructed arenas in which actors struggle for power" (2012, p. 13). Their field theory is partly based on theories of Bourdieu (1985), but differs in its acknowledgment that fields are not necessarily stable; social agents can change the power relations within a field. The instability of the field makes the theory apt for political style, as the social dimension of political style can be characterized as an attempt to change the power relations in the political action field.

Strategic action fields consist of three elements. First is the incumbent, referring to the group of actors that have disproportionate power within a field. Their power and superior access to recourses cause the field structure and rules to favor their interests. The second element is the challenger, referring to the group of actors that have an underprivileged position within the field. The challengers are less influential and must obey the dominant field order, usually against their direct interests. The third element is the governmental unit. This element controls obedience to the field rules and guides the performance and the reproduction of the field (2012, pp. 13-14).

Besides these three elements, there are two other factors relevant to the power struggle within an action field. These elements make the field open to change. One (the fourth element) is that approximate fields must be in a state of chaos and crisis; only then, will the challenger be in the position to gain power. Otherwise, the incumbent party, having the advantage of field rules and access to recourses, will be able to hold its leading position (2012, p. 9). Lastly, social action itself is essential in order to change the power relations within a field (2012, p. 17). 
Fligstein and McAdam emphasize how critical social skills are for gaining power in a strategic field. Framing the political field in a way that is beneficial for the challenger or incumbent party is a crucial strategy and skill, necessary for changing or beholding the power relations within the field (2012, p. 17). Hence, the social dimension of political style can be defined as a specific framing of the political field. This framing is structured around the abovementioned elements, which are useful as focal points for analyzing political style in the social dimension:

I Challenger:

2 Incumbent:

3 Governmental unit:

4 Strategic action:

5 Proximate fields:
The group not in power / the underdog as victim or not The group in power / the elite as culprit or not Democracy/government as legitimate or not In defense or in contention / politics as conservative or progressive

The political context / as in crisis or progress

\subsection{Political style in five elements.}

Comparing the elements of the social dimension of political style with the elements in the presentational dimension shows that they broadly align:

I The group not in power aligns with the people;

2 The group in power only partly aligns with politicians, however, when formulated as the political elite, the two elements match (c.f., Lasswell, Lerner, \& Rothwell, 197I);

3 The governmental unit aligns with democracy-government;

4 Strategic action aligns with politics, and;

5 Proximate fields align with the political context.

As the ideational dimension manifests itself in the above-analyzed dimensions, it follows that these five elements apply to all three dimensions of political style. Therefore, for assessing political style in general, these five elements are chosen as focal elements. The choice assures that the vital parts of political style are analyzed and that all analyses are comparable. It also allows for more detailed analyses and comparisons of political styles; for instance, in Chapters 3, 5, 6, and 8, political styles are compared at the detailed level of elements. 


\section{Style Labels}

Having defined political style as a discursive performance and having established its three dimensions and five focus elements, we are left with the choice of style labels for differentiating political styles. These style labels should, ideally, cover all dimensions and elements of political style, as well as refer to the political surroundings that they are analyzing. As De Haan argues (2000, p. 238), inventing new style labels—or borrowing them from other fields such as art, music, or fashion—rather complicates more than clarifies current political science issues. These styles are "circular"; they allow no further conclusions than that there are personal differences in style (2000, p. 238).

This requirement dismisses the art/poetry inspired style labels of Ankersmit, the elegiac versus the satirical political style $(2000,2003)$. Hariman's labels (1995) do refer to a political context; he discerns a realist, courtly, republican, and bureaucratic political style. However, only the bureaucratic style is relevant to contemporary democracies; the other three refer to classical and renaissance Rome and to an African autocracy. The same problem counts for Cicero's Attic and Asiatic style (Cicero, trans. 2012; Kennedy, 1999: 4849); these are meaningful in the political context of the first century BC, but not for today. Another option was using five political styles described by Koenis (2014, pp. 19-37), named after the solutions that most Dutch politicians see for the main problem of a specific period (2014, p. 19). Since WOII, Dutch politics encountered the emancipatory style, the wellbeing style, the business administrative style, a communitarian style, and a populist style. Different periods in history face different problems, and this affects the style of most politicians. The advantage of Koenis' application of political style is that the link with the political context offers a better insight into Dutch politics. However, for seeing differences in political styles within one period, the styles do not suffice. For this, multiple simultaneous occurring styles need to be distinguished.

One well-known present-day political style label is the populist style. Choosing this label links this study to the most debated questions in political science of this moment; the recently observed global rise of populism (e.g., Moffitt, 2016; Norris \& Inglehart, 2019), as well as the discussion on the nature of populism (e.g., Gidron \& Bonikowski, 2013; Kaltwasser et al., 2017). If this dissertation can analyze political style in terms of populism, it will contribute to two highly debated issues in political science. A broad initial comparison of populism features in the literature suggested that populism was indeed an adequate label for 
political style, as all five elements could be formulated in a populist style (see Chapter 3). The question was if all features of populism also fall within one of the five categories of political style. To answer this, Rooduijn's (20I4) inductively gathered features of populism were compared with the five elements of political style. A secondary analysis of Rooduijn's data demonstrated that it is not only the core elements of populism, but in fact all inductively gathered features of populism that fall under the five elements of political style (see Appendix C). This bolstered the idea that populism was an adequate label for political style.

Choosing the populist label, however, is not enough; a style requires at least one contrasting style. One option is to compare populism with "normal" politics, as done by, for instance, Jagers and Walgrave (2007). This opposition, however, is based on the assumption of a dichotomy between a normal, not-stylized (= mimetic) politics, and a stylized, populist one (= aesthetic). As explained in section 2 , this is at odds with the conclusion that all of politics is stylized.

In the populism literature, there are many concepts to which populism is opposed. Mudde (2004) compares populism with pluralism and elitism, while others place populism opposite technocracy (e.g., Laclau, 2005a; Moffitt \& Tormey, 20I4; Taguieff, 1998). Canovan (1999) contrasts populism to a pragmatic style, whereas Pappas (2016) opposes populism to liberalism. All these oppositions carry their own truth; the question is which of them works best as a contrasting style of populism as political style. A comparison with the five elements of political style demonstrated that elitism and pluralism, cover the five focus elements of political style best (see Chapter 3). The three styles were compared in more detail based on the literature on elitism (i.e., Bachrach, 197I, 1980; Best \& Higley, 2010; Borchert, 2010; Dahl, 197I; Engelstad, 20I0; Körösényi, 20I0; Lasswell, Lerner, \& Rothwell, 197I; Mackie, 2009; Schumpeter, 2008), pluralism (i.e., Blokland, 20I I; Dahl, 196I/2005, 1956/2006; Lijphart, 1968), and on the populism literature (i.e., Canovan, 1999, 2002; Laclau, 2005a, 20I4; Laclau \& Mouffe, I985; Moffitt, 20I5, 20I6; Mudde \& Kaltwasser, 20I3, 20I7, 20I8; Ostiguy, 2017; Taggart, 2002; Weyland, 200I).

Initially, the relationship between the three was conceptualized as linear: populism and elitism forming the poles of a scale with which political style could be measured, and pluralism holding a middle position. In this configuration, pluralism is both the opposite of elitism and populism, as well as a mix. For instance, populism views the elite as corrupt, as opposed to elitism, which sees the elite as good. The two form the poles of a linear scale, 
the middle of which is pluralism, which views the elite as a group consisting of good and bad individuals. A similar pattern is visible in all five elements. Questions, however, arose as not all populism-elitism mixes could be characterized as pluralism.

In order to investigate the relation between the three styles in more depth, and reexamining whether the three labels—-populism, elitism, and pluralism-were the right choices, Chapter 4 of this dissertation conducts a concept analysis of populism in contrast with many other concepts. With the help of A.J. Greimas' semiotic square (1970/I987), a semiotic analysis demonstrated the three labels as a good match but also revealed a shortcoming; the linear scale had to be molded into a triangular one, as the styles were found to be each other's opposites and companions in shifting coalitions in the three dimensions. The complicated knot of meaning answers the question of why populism is often understood as an inherently incongruent concept (e.g., Stavrakakis, Kioupkiolis, Katsambekis, Nikisianis, \& Siomos, 2016); it manifests itself in fundamentally different ways in each dimension of political style:

- In the ideational dimension, populism is paired with elitism; together opposing pluralism in the opposition of viewing the people as one homogenized or unified people (populism and elitism) versus viewing the people as an assemblage of multiple groups and individuals (pluralism);

- In the social dimension, populism merges with pluralism; as a pair opposing elitism in the opposition of no power to the elite (populism and pluralism) versus power to the elite (elitism);

- In the presentational dimension, pluralism and elitism together oppose populism in the opposition of indirectly representing the people (pluralism and elitism) versus directly being the people (populism).

Together, the three oppositions precisely demarcate what populism is and is not. Further semiotic analysis shows that the three styles precisely complement each other in mixing a personal, group, and systematic style evenly over the three dimensions. In its base, political style is a group style - purposed to connect with groups of people. A pure group style, however, is utopian; groups consist of individuals who need systems to reconcile group interests with individual interests. Inevitably, personal as well as systematic style elements are integrated with political (group) styles. 


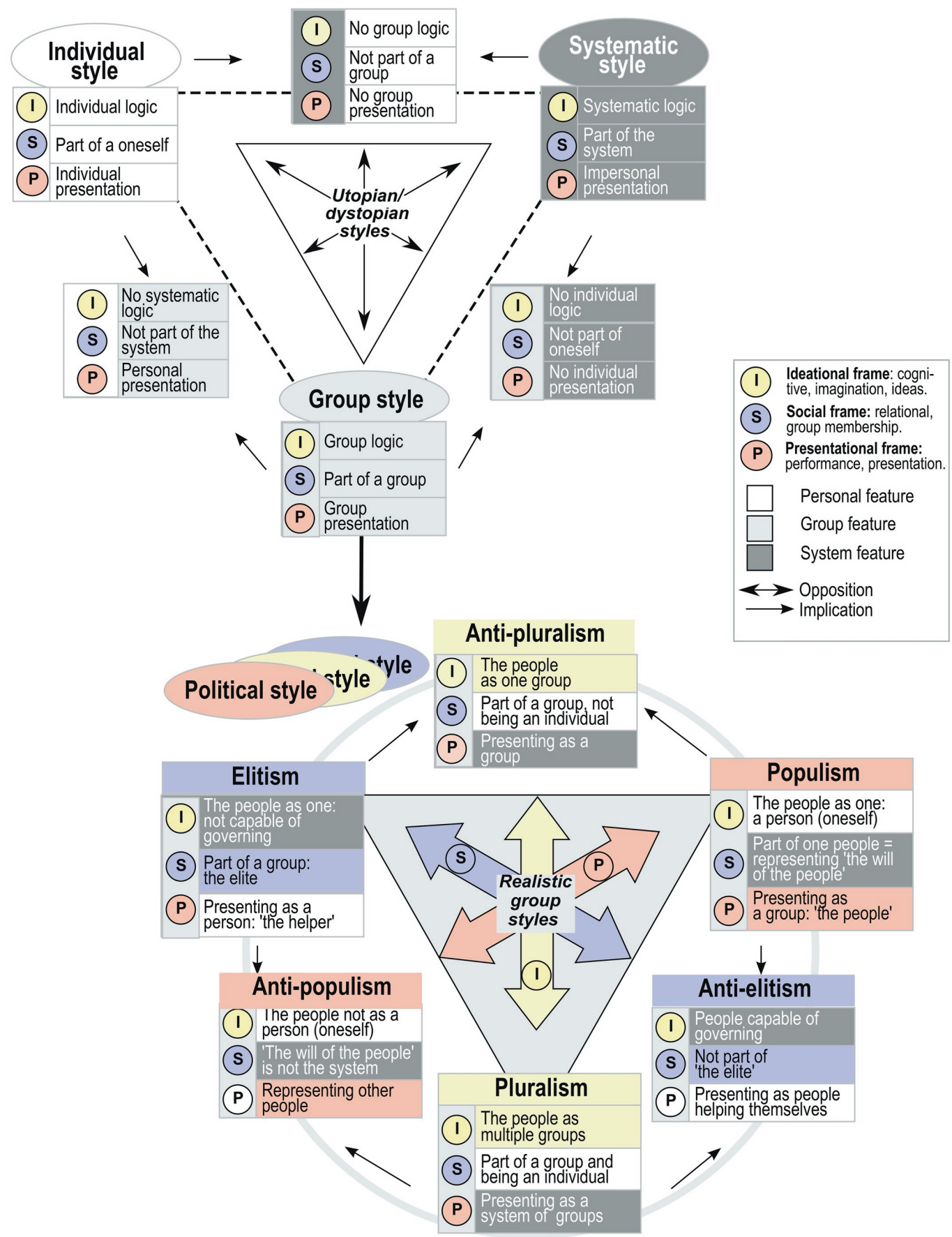

Figure 2.I A political style as a group style in one dominant framing, incorporating individual and systematic elements. 
Populism has a personal ideational dimension (the people as a (whole) person, oneself), whereas pluralism has group ideational dimension (the people as a group consisting of individuals (parts)), and elitism a systematic ideational dimension (the people (whole) as notgoverning). Within the other dimensions, the group, individual, and systematic styles shift like clockwork (see Figure 2.I). This logic shows the three styles as one constellation of concepts, explaining the styles at an abstract level. Although politicians often mix styles, it is always clear which style or anti-style a fragment has, in terms of one dimension and one element. In this way, the combination of the labels populism, elitism, and pluralism provides a Sartori-proof categorization of political styles. Sartori stated that labels in the social sciences must reflect unambiguous categories (Sartori, 1970, I99I). With populism, this has always been problematic, as the concept of populism is notoriously vague (Aslanidis, 2017; Pappas, 2016; Van Kessel, 2014). Laclau states that this vagueness is inherent to the populist concept, as populism is a discursive act that differs per context (Laclau, 2005a, p. 85). Nevertheless, this dissertation shows that if populism is assessed in a triangular relationship with elitism and pluralism, within this restricted space, unambiguous answers are within reach. Populism still differs per context, but becomes comparable at a higher abstraction level, in its relative meaning towards elitism and pluralism. Chapter 4 explains this triangular interdependency more elaborately.

\section{Political Style and Metaphor}

Theoretically, metaphor plays a crucial role in political style as it is through creative metaphor usage that the language system opens up for frame changings, necessary for political change. In Chapters 7 and 8, I explored the purposes of present metaphors in political speeches and found confirmation for the theoretical connection between metaphor usage and differences in political style. Three types of metaphor have links with the three dimensions of political style, as well as with the three political style labels. As explained in Chapters 7 and 8 (see also Figure 1.5):

- populism is related to pathos and emotion-based metaphor;

- elitism is related to ethos and strategy-based metaphor; and

- pluralism is related to logos and ratio-based metaphor. 
Notwithstanding a theoretical connection between metaphor usage and political styles, the link does not show itself straightforwardly in political discourse, probably because the three dimensions of discourse are too much entangled to distinguish simple connections. In order to get more grip on the matter, many more metaphor analyses need to be conducted, such as the ones in Chapter 8. In Chapter 9, I describe the ways in which this theoretical link can be further explored via the connection of political metaphor analyses to the framework of political style, as presented in this dissertation.

\section{Conclusion}

This chapter defines political style not as an opposite of political ideas but as encompassing these. Political ideas are inseparable from their materialization in language and social action because they are all circularly related; they generate each other. Hence, ideas are one aspect of the broader defined style of a politician.

Political style can be regarded as a three-dimensional political performance generating political meaning: in the ideational dimension (cognition, ideas), social dimension (social relations and action), and presentational dimension (communication and rhetoric). The three dimensions all have their own logic. For this reason, it is essential to study each dimension separately to get a full understanding of the meaning expressed by a politician's political style.

Populism, elitism, and pluralism are a useful set of labels for empirical research into political style in the current political context of Western democracies. The precisely oppose and complement each other, for which reason they can be used to characterize all occurring political styles, populist or mainstream. They make political styles comparable at an abstraction level higher than the political contexts themselves. 



\title{
3 \\ In the Theater of Political Style
}

\author{
Touches of Populism, Pluralism, and Elitism \\ in Speeches of Politicians
}

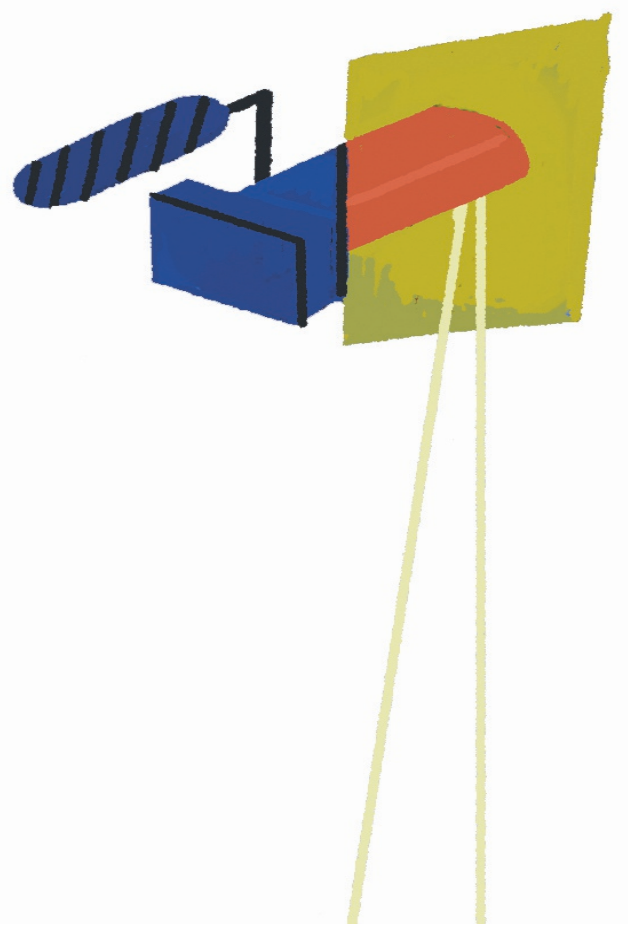

This chapter is a minor revision of: Schoor, C. (2017). In the theater of political style: Touches of populism, pluralism, and elitism in speeches of politicians. Discourse \& Society, 28(6), 657- 676. DOI: |0.1|77/09579265|7721082 
The "secret" to be unveiled through analysis is not the content hidden

by the form but, on the contrary,

the "secret" of this form itself.

Žižek, The Sublime Object of Ideology, p. 3.

\section{Abstract}

Up to date, the concept of political style is underdeveloped, obstructing a profound understanding of political performances. This paper disentangles the components of political style by analyzing the concept systematically. It is argued that political style has to be regarded as occurring in three dimensions: the presentational, social, and ideational. As an example, a style analysis of six speeches of US politicians Donald Trump, Bernie Sanders and Hillary Clinton is performed. The analysis shows Trump having a full populist style, Sanders a populist-pluralist style and Clinton an elitist-pluralist style. Comparison of the three individual style profiles gives a clarification for otherwise unexplained differences and similarities between the three politicians.

\section{Introduction}

Currently, in most modern Western democracies, classifications of politicians are problematic. For instance, in the United States, political opponents Donald Trump and Bernie Sanders both criticize the same political elite and agree on subjects such as trade and infrastructure. Similarly, in France, extreme right Marine le Pen and extreme left Jean-Luc Mélenchon both want to change French policy radically, proposing to leave the European Union. Similarities such as these are often explained as populist in contrast with normal or pragmatic politics (Canovan, 1999). These politicians would share a populist style, but at the same time differ in "full" ideology, because populism is not a full ideology itself, but a political style or "thin-centered ideology" (Mudde, 2004, p. 544).

However, this definition of populism poses a contrast between ideology and political style that does not match the observation that ideologies today are not as clear-cut as they have seemed in the past, given the above-sketched similarities between left- and right-wing politicians. Based on theories on ideology and style, I suggest that style should not be seen as something apart from ideology, but as a modern, fragmented shape within which ideological thought is expressed. It is based more on common sense than on ideological theory (Van 
Dijk, 1998, 2015), and can be seen as a tag-cloud of issues scattered over the (new) media. This cloud is the ideational dimension ${ }^{3}$ of political style. It is held together by the social and presentational dimension of political style: the former is used to connect with a group of voters sharing the same style; the latter aims at persuading people who do not share that style (yet). The three dimensions together form the political style of a politician. This redefinition of political style, splitting it up in a ideational, social and presentational part, is grounded on style theories from diverse disciplines (political science, political philosophy, rhetoric, sociology and sociolinguistics) (e.g., Ankersmit, 1996; Coupland, 2007; Giddens, 1991; Hariman, 1995; Moffitt, 2016; Pels, 2003a).

This chapter further examines the nature of political style. Regarding it as a loose collection of ideological meaning, this chapter adapts critical discourse studies (CDS), since this approach mainly focuses on revealing hidden ideological meaning in discourse. With the help of the discourse-historical approach to CDS (Reisigl \& Wodak, 20I5; Wodak, 20I5), this chapter offers a set of tools for style analysis of political performances. These tools are based on theories of political performanc (Wodak, 2009), on ideological theory (Thompson, 1990; Van Dijk, 1998, 20I5), and Goffman's (1956) theory on the presentation of the self in everyday life.

Five core traits of political style are identified where politicians in modern Western democracies can be compared. Labels of three main styles are adopted from the historical context (elitism, pluralism, and populism) and defined with the help of political research (i.e., Bachrach, I97I, I980; Best \& Higley, 20 I0; Blokland, 20II; Dahl, I97I, 1956/2006; Lasswell et al., 197I; Mudde, 2004; Rooduijn, 2014). Using this method for speech analyses of candidates in the 2016 US primaries (Trump, Sanders, and Clinton) results in the disclosure of unique combinations of elitism, pluralism, and populism. These combinations form individual political style profiles, contributing to a better understanding of the performances of these three politicians.

3 In the original article, ideological, group and communication style were used instead of ideational, social, and presentational dimension. To better align with the other chapters, the labels are adapted to the ones used in the rest of this dissertation. The adjustment of labels is motivated in Chapter I, section 3.3. 


\section{Ideology Changing Form}

Due to media developments, the political environment has dramatically changed over recent decades. This has had a great impact on political style. According to Street (2003), today's politicians can be compared to film stars: "Skills of performance are skills in selfpresentation, in style. Style matters to politics, just as it does to other cultural forms" (p. 95). In today's "audience democracy," a politician is a media-expert, a person who excels in communication through the modern media. In this type of democracy, "a candidate (...) must not only define himself, but also his adversa-ries. He not only presents himself, he presents a difference" (Manin, 1997, p. 222).

Considering the strong connection between mass communication and the emergence of ideologies, this new mediated environment changes the very core of ideology. In the late$18^{\text {th }}$ century, mass media was a condition for the rise of traditional ideologies ${ }^{4}$ (Gouldner, 1976, Pp. 91-1 I7; Thompson, 1990, Pp. 82-85). As the media was a print form, the newly formed ideologies were bound to written theory; not only was verbal logic required to form coherent arguments, the editors of newspapers and publishing houses belonged to an intellectual class that favored thoroughly deliberated theories. This changed in the second half of the 20th century when the dominant media shifted from printed to televised and online media. The newer media allow a looser assemblage of ideological content where images are as important as words. This assemblage does not need a profound coherence because its content is spread in fragments over television and the Internet. This ideological style is mostly based on what Van Dijk (1998, pp. 103-107) describes as "common sense"; socially shared representations, based on immediate experiences and on simplified scholarly knowledge, as communicated through mass media. Consequently, people no longer need to be educated to a level of ideological competence in order to judge politicians; they can judge them based on political style and taste (Pels, 2003a, p. 50).

In sum, within the last few decades, communicated ideological meaning has changed from verbal long stories/theories into visual/auditory tag-clouds/styles. This does not mean that traditional ideologies are necessarily dead, but rather that they have a new strong

$4 \quad$ The concept of ideology in this chapter is used in two senses; the traditional as a system of ideas and the critical conception of "the interface between social structure and social cognition" (Van Dijk, 1998). When traditional ideologies are meant, this is mentioned in the context. 
competitor in ideological style. It is still difficult to make sense of these new forms of communicated ideological meanings because people are used to looking for a coherent long story or theory. In order to see a new sort of coherence, ideological styles must be examined alongside traditional ideologies.

One similarity between traditional ideologies and ideological style is that both can be defined as "the interface between social structure and social cognition" (Van Dijk, 1998, p. 8). It means that it serves as the basis for shared representations of a group. Furthermore, according to Van Dijk, analysis of ideological meaning has to consider three levels: first, these representations consist of a cognitive frame in which issues are regarded (cognitive level); second, ideology is always shared by groups (social level); third, ideology is always expressed in language or non-verbal communication (presentational level). Applied to political style, it results in its definition as the stylized manner in which ideological thought is expressed in language and group behavior. To understand how ideological style is politically used, the concept needs to be regarded in the broader context of political style.

\section{Three Dimensions Within Political Style}

Long before the emergence of political ideologies, political styles were acknowled-ged. In classical Rome, Cicero (trans. 2012) distinguished two styles; the sober Attic style, based on ancient Greek rhetoric, and the bombastic Asiatic style developed in Roman cities in Asia Minor. The Attic style appeared more sincere because of a lack of rhetoric, while the abundance of rhetorical elements of the Asiatic orators was thought to be more powerful. Cicero preferred the Asiatic style in front of the people at the Forum. For a more educated audience at the Senate, he typically favored the sober Attic style. (Cicero, trans. 20I2; Kennedy, 1999: 48-49).

Traditionally, political style was merely a matter of persuasion. Following Aristotle's Rhetoric, politicians had to adjust their performance according to their audience to be effective. For instance, a young audience demanded a different style than an older one, and educated listeners another style than those less literate (Aristotle, trans. 1984, Rhet. I390 a 25).

Today, however, sociologists and sociolinguists might frame the two Roman styles as the styling of social identities or as self-identities adjusted to different lifestyle sectors (Coupland, 2007; Giddens, 199I). Within modern sociological theories, identity is not unitary, fixed, and 
stable but plural and co-constructed in interaction with people, things, and spaces. This identity building is a creative process in which people express both their social identity and their search for social roles (Coupland, 2007, pp. 106-108).

Contemporary political scientists, on the other hand, frame political style as "aesthetic representation"; within the context of modern representative democracy (in contrast with Cicero's direct democracy) political styles are regarded as creative fillings of the "aesthetic gap" between the representative and the represented. Because politicians can never be identical with the people they represent, they have to bridge the difference creatively, like a painter paints a portrait (Ankersmit, 1996, pp. 49-56; Pels, 2003a, p. 49). Ankersmit and Pels differentiate between a mimetic and an aesthetic approach to democracy; a mimetic approach denies the gap and is therefore at odds with the representative nature of democracy. In an aesthetic approach, politicians seek connection with a group of people through a shared style and taste, without suggesting being identical (Ankersmit, 1996, pp. 49-56; Pels, 2003a, p. 49).

Although the notion of the aesthetic gap is valuable and is for a large part in accordance with the notion of social style, there is one dissention: in social theory there is no such thing as a not-stylish (mimetic) approach: all social behavior, including politics, is inevitably stylish (Giddens, 199I, p. 8I). In this regard, the mimetic approach can be seen as an anti-style, denying the existence of political styles, and just another way to fill the aesthetic gap.

In this interpretation, I define political style as "a stylized political performance purposed to fill the 'aesthetic referential gap' with a political identity." This identity is partly constructed through the expression of ideological thought, and partly through expressions reflecting the style of certain social groups, in order to connect with these groups. Additionally, political style is about persuading people who are different and do not think alike (yet). Therefore, political style comprises of three dimensions:

I ideational (the fragmented expression of ideological thought);

2 social (the co-construction of identities in interaction with others);

3 presentational (language use aimed at persuasion) ${ }^{5}$.

5 There is a parallel between these three dimensions and the three meta-functions of human interaction, discerned by Halliday: the ideational, interpersonal, and textual functions. Not only has Halliday been influential 
In practice, the three dimensions are blurred. Nevertheless, for analytical purpose a distinction is advantageous; it allows seeing that politicians creatively combine ideational elements with social and presentational aspects. For instance, many politicians with populist ideas choose a matching social style, expressing to be part of the people, but this is not mandatory. Pim Fortuyn, for instance, a well-known Dutch politician, mixed mainly a populist ideational style with a clear elite social style: driving a Daimler, wearing expensive Italian suits, and coquetting with his former title of Professor. This elite social image did not make him an elitist altogether, but it gave him a unique stylized political profile, that was ideationally, socially, and rhetorically attractive. It is a creative way to "fill the aesthetic gap", and a solution to the problem that all modern populist politicians face - having to be “ordinary and extra-ordinary at the same time" (cf. Moffitt, 2016, p. 55).

This example entails that for the analysis of political style, style labels are needed that encompass the social, ideational, and rhetorical/presentational dimension. Existing political style labels either refer to rhetoric, using classical concepts such as logos, ethos and pathos in combination with modern rhetorical theory (as in Chapter 7 of this dissertation, and; Charteris-Black, 2009), or to social styles, such as the four styles of Hariman (1995). Although Hariman's realist, courtly, republican, and bureaucratic styles do refer to political surroundings (such as classical Rome, African autocracy, and European contemporary bureaucracy), they do not refer to different styles within the political context of the analyzed performances. This makes labels circular, as De Haan argued (2000, p. 238); they allow no further conclusions than that there are personal (read social) differences in style. Such labels will not enhance insight into the political context; they can even obstruct it. Ankersmit proposed to use political style labels borrowed from painting or music styles, however, these labels also lack a link with the political context (Ankersmit, 2000, 2003; De Haan, 2000).

For insight into the political context, political style labels are needed. One known style label referring to the political context is the populist style, but it is unclear which other styles it relates to. Mudde (2004) compares populism with pluralism and elitism, while Moffitt (2016) opposes it to the technocratic style, a style combining expert knowledge with good manners and a belief in progress. Canovan, on the other hand, opposes populism to a pragmatic style

for CDS (Halliday \& Mathiessen, 2004; Wodak, 200I; Wodak \& Meyer, 20I5); the three dimensions and the three meta-functions both trace back to the same three tensions in discourse mentioned in Chapter 2. 
favoring practical solutions over visionary beliefs (1999). To decide which labels apply, it is needed to develop the political and ideological style concept further.

\section{Political Style and the Theatre Concept}

Thus far, political style has not been analyzed systematically. The theater concept can be of help here because it is a common metaphor for politics and social behavior and has facilitated the way people think of both (cf. Lakoff \& Johnson, 1980). Earlier, De Haan (2000, Pp. 246-248) pointed at the usefulness of the theatre to comprehend political style, as it expresses its aesthetic and interactive character. Recently Moffitt $(2016$, p. 49) used the theatre to explain the performative character of populism as political style.

Traditionally the theatre concept has been used by rhetorical scholars for centuries, visible in concepts such as decorum with remarks on tone and gesture (Hariman, 1995, p. 180; Kennedy, 1999, p. I10). Since the $19^{\text {th }}$ century, political observers also used the theater metaphor to express the theatrical character of revolutionary political situations (Fitzgerald, 2015). During the second half of the 20th century, political theorists adopted the metaphor to stress the mediated character of politics. Television evoked the image of politics as a broadcast show that voters at home could follow more directly than ever (Edelman, 1988; Green, 2010; Manin, 1997). An objection to the theater concept is that the metaphor would depict politics as an "elite play" in which the audience can only passively watch. However, this underestimates the active role of the audience/spectators; according to Green, a "gaze" includes a judgment. According to Edelman this judgment is crucial for the acceptance of an issue as a political problem or not (Edelman, 1988, p. 32; Fitzgerald, 20I5; Green, 2010, Pp. 128-129).

Besides for politics, the theatre metaphor is used for social life, most notably by Goffman (1956). In his theory on the presentation of the self in everyday life, all people perform a play in their interactions, and most of the plays are standardized so that observers can easily understand a situation (Goffman, 1956, p. 16). Wodak (2009) elaborated further on Goffman's theory, focusing on political situations. Like Goffman, Wodak discerns a frontstage and a backstage: at the frontstage, the political performance takes place before an audience. This frontstage requires a setting, for instance parliament or a television broadcast, and a personal front. This personal front has two aspects: appearance and manner. Appearance refers to items that reflect the social status, and manner to the way actors conduct 
themselves (Wodak, 2009, pp. 9-10). Although Wodak does not use the words "political style," personal front clearly equals political style as it refers to politicians' appearances (a dress-code, the entourage of a politician, his car etc.) as well as to their manner (the way they speak, what they say, whom they are friendly with and whom not, etc.). Where Wodak focuses on the backstage (Wodak, 2009, Pp. 23, 36, 56), this chapter concentrates on the frontstage to define the traits political performances consists of, by comparing frontstage elements such as stage, play and audience with elements of a political performance.

When applied to modern representative democracies, the picture is as follows: in the political theatre, actors (politicians) perform a play called democracy. The set is the location of a speech or debate: in parliament, on television, etc. The stage represents socio-historical context: the country, available technology, and historical events. The roles of the actors differ: being a parliamentarian or part of the government. Because the democratic play does not allow just one director (this would be an autocracy), all politicians are their own director, more or less co-directed by their party. The script is offered by traditional ideologies, but actors can also choose to improvise their performance or use multiple scripts of different ideologies.

Without mandatory scripts or directions, all actors produce their own performance. This is their political style. The stage, being the socio-political context, alters in time, and accordingly the audience changes and uses different technology. Because the play resembles a television contest, the audience endorses or declines the actors during the play, calling them to leave or to adjust their appearance. Also, the theatre (politics as a whole) and the play (democracy) are under constant critique, or the gaze of the audience. Media has the role of super-audience; because they control the spotlights, they draw the attention to one actor or another, and because they have the loudest voice, they also impact public opinion.

\section{Defining Core Traits of Political Style}

The political theatre as sketched above offers insight into the elements constituting political style if these elements are linked to the frontstage characteristics defined by Goffmann (1956). Furthermore, four context levels must be reckoned with (Reisigl \& Wodak, 20I5, p. 93). Table 3.I shows these context levels in relation to Goffmanns' front stage elements, along with those of the political theatre. 
In Goffmanns' terminology, political style, involving manner and appearance, consists of elements I-4 from Table 3.I: speech; non-verbal communication; dress-code and other entourage elements, and; political role. The former two elements concern the text level while the latter two mostly belong to the social variables and institutional frames. This means that political style can be described through observation of Element I-4. By comparing these descriptions with social styles from the historical context, the style in the social dimension can be revealed. To apprehend the rhetorical/presentational dimension of

\begin{tabular}{|c|c|c|c|c|}
\hline & $\begin{array}{l}\text { Theatre } \\
\text { metaphor: }\end{array}$ & Politics: & $\begin{array}{l}\text { Goffmann: } \\
\text { frontstage }= \\
\text { setting }+ \\
\text { personal front }\end{array}$ & $\begin{array}{l}\text { Wodak's } \\
\text { contexts } \\
\text { levels }^{a}\end{array}$ \\
\hline & Performance & $\begin{array}{l}\text { Political style = } \\
\text { rhetorical/presentational + social + } \\
\text { ideational }\end{array}$ & $\begin{array}{l}\text { Personal front }= \\
\text { manner }+ \\
\text { appearance }\end{array}$ & I, 2, 3 and 4 \\
\hline $\mathbf{I}$ & Lines & The speeches that are uttered & Manner & I \\
\hline 2 & $\begin{array}{l}\text { The acting } \\
\text { itself }\end{array}$ & $\begin{array}{l}\text { Non-verbal communication, } \\
\text { movements, gestures etc. }\end{array}$ & Manner & I \\
\hline 3 & $\begin{array}{l}\text { Props and } \\
\text { costumes }\end{array}$ & $\begin{array}{l}\text { Dress-code (formal or informal), } \\
\text { entourage (i.e. security) etc. }\end{array}$ & Appearance & I, 3 \\
\hline 4 & Roles & $\begin{array}{l}\text { Member of parliament or } \\
\text { government; opposition or coalition; } \\
\text { Candidate in elections or not, etc. }\end{array}$ & Appearance & 3 \\
\hline 5 & The theatre & Politics & Setting & 2,3 \\
\hline 6 & The play & $\begin{array}{l}\text { Democracy, consisting of multiple } \\
\text { acts, such as: a parliamentary debate, } \\
\text { elections, governing, canvassing etc. }\end{array}$ & Setting & 2,3 \\
\hline 7 & The actors & Politicians & Setting & 2,3 \\
\hline 8 & The audience & $\begin{array}{l}\text { The people / voters, the media } \\
\text { (super-audience) }\end{array}$ & Setting & 2,3 \\
\hline 9 & The set & $\begin{array}{l}\text { Institutional surroundings / location: } \\
\text { parliament, government, party } \\
\text { gathering, television broadcast etc. }\end{array}$ & Setting & 2,3 \\
\hline 10 & The stage & $\begin{array}{l}\text { The socio-historical context: the } \\
\text { country, occurring crises and } \\
\text { historical events, available } \\
\text { technology }\end{array}$ & Setting & 2,4 \\
\hline
\end{tabular}

${ }^{a}$ Note: Context levels: I = text level; 2 = discourse /intertextual level; 3 = social variables and institutional frames; $4=$ social-political history.

Table 3.I Analysis of the frontstage of politics related to Goffmanns (1956) and Reisigl and Wodaks (20I5) definitions. 
political style, language use (Element I) can be analyzed with help of rhetorical theory. Lastly, to define the ideational dimension of political style, the four style elements have to be interpreted in relation to ideological differences.

Traditionally, the socio-historical context (Element 10, the stage) was the focus of political researchers to define the differences between politicians on ideological issues. However, politicians can also differ in the style in which they frame the context: they can look at it as being in crisis or as under control. In the same manner, politicians can differentiate themselves on other elements of the political setting (Element 5-10), because all these components possess a discourse component besides their extra-linguistic/institutional nature. For instance, Element 5 Politics, obviously has an institutional side (an institutional rule is, for instance, the prohibition of physical fights), but within this institutional frame some politicians see politics as cooperation, while others see politics as conflict. This differentiation is possible on all mentioned elements (5-10 in Table 3.I). Even Element 9, Location, is for some a respected institution, and for others a fake parliament.

So, besides the traditional ideological differences on political issues, politicians can deliberately make an ideological difference to other aspects of a political performance. A political style analysis should therefore look at elements 5-10 in Table 3.I, forming the core traits of political style: Politics, Democracy, People, Politicians and the Context. Because location is very context-specific and directly connected with other traits, it is integrated in the other traits.

So far, this chapter has discussed three levels and five core traits of political style but is not useful as an analysis instrument yet. These traits and levels have to be combined with labels derived from the political context, encompassing the three dimensions. Before picking any label from an abundance of seemingly applicable isms, the maximal ideological differences on the five traits should be logically subtracted. This deductive approach guarantees that the right labels are selected to most accurately match ideological style. Logically the largest possible ideological differences are:

People: $\quad$ the people are good vs. bad;

Politicians: politicians are good vs. bad;

Politics: $\quad$ politics as conflict vs. cooperation;

Democracy: people's self-governance vs. people electing others to govern;

Context: the historical context is in crisis vs. under control. 
Earlier in this paper, populist, elitist, pluralist, technocratic and pragmatic styles were mentioned as existing political style labels. Relating these labels to the five style traits reveals whether these styles are apt to use for political style or not.

Comparing known descriptions of populism with the five traits indisputably positions populism at one extreme end of all traits: populists see: (I) the people as good, (2) politicians as bad, (3) democracy as people's self-government, (4) politics as conflict and (5) the historical context as in crisis (Akkerman, Mudde, \& Zaslove, 20I4; Hawkins, Riding, \& Mudde, 2012; Moffitt, 2016; Rooduijn, 20I4). So evidently populism settles as political style.

Furthermore, comparing the five style traits with the technocratic style (Moffitt, 2016, p. 46), suggests that the latter only refers to the, context-dependent, social dimension of political style - one of the three components of political style. The technocratic style associates itself directly with a social group of experts, while its features only partly, and more indirectly, refer to the ideational and presentational style traits. As a social style, it is better to oppose the technocratic style to a popular (social) style, rather than to a populist (political) style.

The same applies for the pragmatic style of Canovan (1999): it associates itself primarily with a social group of hands-on entrepreneurs and solution seekers, while in the ideational dimension only resembling the political style traits of politics and context. As a social style, it is better to oppose this style to a visionary style, rather than to a populist (political) style, which is broader.

Elitism and pluralism, both described by Mudde (2004, pp. 543-544) as oppositions to populism, directly refer to all five traits. Theoretical descriptions of elitism situate it at the other end of the ideological style scale, opposite to populism (Akkerman et al., 2014; Bachrach, I97I, 1980; Lasswell et al., I971; Mackie, 2009; Mudde, 2004; Schumpeter, 2008). Descriptions of pluralism show that pluralism positions itself exactly on the middle of the scale on the five traits (Blokland, 20I I; Dahl, 1956/2006). This means that populism, pluralism, and elitism settle as political styles, as demonstrated in Table 3.2.

I suggest with populism, pluralism, and elitism, the basic scale of political styles being set; elitism and populism holding the end positions and pluralism occupying the middle. However, both populism and elitism are not exclusively practiced within generally accepted democratic boundaries (Moffitt, 2016, p. 140) - undemocratic forms of elitism and populism form the real ends of the scale as extreme elitism and extreme populism. Additionally, two mixed forms of populism-pluralism and elitism-pluralism can be inserted to keep the scale 
balanced and get a better view of the differences between pluralist styles. Questions might rise because the scale levels a mixed elitist-populist score into an average pluralist score. This is accurately so, because a mixed elitist/populist score inevitably means that the politician is a pluralist, albeit performing in a stylized manner.

With a seven-points style scale (varying from extreme populism to extreme elitism), five style traits (the people, politicians, democracy, politics, and the context), and three dimensions (ideational, social, and presentational) the structure of the analysis tool is ready. It consists of five rubrics on three levels, describing five styles on each trait ${ }^{7}$. Based on this structure, a computer-based analysis instrument for the detection of political style elements in speeches is developed: the PEP-index, named after the initials of populism, elitism, and pluralism. In the following section, I give examples of an analysis using the PEP-index.

\begin{tabular}{|l|l|l|l|}
$\begin{array}{l}\text { Ideological } \\
\text { style / traits }\end{array}$ & populism & pluralism & elitism \\
\hline $\begin{array}{l}\text { I The } \\
\text { people }\end{array}$ & $\begin{array}{l}\text { The people are one and } \\
\text { good/capable } \\
\text { (exclusion of others) }\end{array}$ & $\begin{array}{l}\text { The people are multiple } \\
\text { groups with different } \\
\text { interests (inclusion) }\end{array}$ & $\begin{array}{l}\text { The people are one and } \\
\text { bad/ignorant } \\
\text { (exclusion of the people) }\end{array}$ \\
\hline $\mathbf{2}$ Politicians & $\begin{array}{l}\text { Politicians are incapable } \\
\text { and corrupt } \\
\text { (exclusion of politicians) }\end{array}$ & $\begin{array}{l}\text { Politicians are, like all } \\
\text { people, likely to do good } \\
\text { but also likely to abuse } \\
\text { power (inclusion) }\end{array}$ & $\begin{array}{l}\text { Politicians are proficient } \\
\text { and good } \\
\text { (exclusion of the people) }\end{array}$ \\
\hline $\mathbf{3}$ & $\begin{array}{l}\text { Democracy is self- } \\
\text { government of the }\end{array}$ & $\begin{array}{l}\text { Democracy is majority } \\
\text { rule, respecting minority } \\
\text { rights } \\
\text { (power to no one) }\end{array}$ & $\begin{array}{l}\text { Democracy is electing an } \\
\text { elite government } \\
\text { (power to the elite) }\end{array}$ \\
\hline $\mathbf{4}$ Politics & $\begin{array}{l}\text { (powflict } \\
\text { Coner to the people) }\end{array}$ & $\begin{array}{l}\text { Negotiation (conflict as } \\
\text { well as cooperation) }\end{array}$ & Cooperation \\
\hline $\begin{array}{l}\text { 5 Political } \\
\text { Context }\end{array}$ & $\begin{array}{l}\text { Negative: focus on what } \\
\text { is lost (crisis) }\end{array}$ & $\begin{array}{l}\text { Factual: focus on facts } \\
\text { (alert) }\end{array}$ & $\begin{array}{l}\text { Positive: focus on what has } \\
\text { been reached (at ease) }\end{array}$ \\
\hline
\end{tabular}

Table 3.2 Populism, pluralism, and elitism compared on five core traits.

6 In Chapter 4, the mixed populist-elitist style has been further scrutinized. This resulted in the creation of a separate category for mixed populism-elitism and an adaptation of the instrument. For the speech analyses in this chapter, this has only minor consequences, as the analyzed styles do not fall within the mixed populismelitism category.

$7 \quad$ The complete rubrics are available at the Open Science Framework: https://osf.io/hdy8p/?view only=de 188 c65ce $144 \mathrm{~b} 39 \mathrm{a} 37 \mathrm{a} \mid 58505 \mathrm{ac59fb}$ 


\section{Political Style of Trump, Sanders, and Clinton}

The PEP-index is used for speech analysis of US politicians Bernie Sanders, Donald Trump and Hillary Clinton encompassing two speeches each from the primaries in April 2016. The complete analysis is too long to include ${ }^{8}$; however, one trait (the people) is discussed in more detail while the other traits are only examined in relation to the general results. The analysis was focused on the whole video performance. Partly captioned video recordings of the speeches were retrieved from the Internet and transcribed (Speeches 3 to 8 in Appendix A). To define the style, speech fragments were compared with the five rubrics of style traits, of which Rubric I (The people) is displayed in Table 3.3. Meaningful fragments (sentences or short paragraphs) were labeled with codes, referring to elements of the rubrics. For instance, the code [IP/PO] refers to a populist score at the presentational level [P] of style trait I (The people, see Table 3.3).

Although the PEP-index allows a quantitative approach, the performed analysis was restricted to qualitative inquiry. For each style element, fragments were selected, studied, and compared to reveal the overall style of each particular style element. Only speech fragments adding new information were included; for instance, as soon as it was clear that a politician spoke with the voice of the people [IP/PO], the focus was no longer on this feature, but on fragments that would suggest other styles on Element IP. If two different styles were detected on one element, an estimation of the quantity was taken into consideration. To be confident that this approach was sufficient, a quantitative analysis has been performed of one complete speech. Because this analysis resulted in the same style score as the restricted qualitative search, the rest of the speeches have been analyzed based on the latter approach.

8 The complete analyses are available at the Open Science Framework: https://osf.io/sq6cm/?view_only=3bf4bf232af44320b28d99fb49/dc557 


\begin{tabular}{|c|c|c|c|}
\hline $\begin{array}{l}\text { The } \\
\text { People } \\
\text { [1] }\end{array}$ & Ideational level [II] & Social level [IS] & $\begin{array}{l}\text { Presentational level } \\
\text { [IP] }\end{array}$ \\
\hline $\begin{array}{l}\text { Extreme } \\
\text { Elitism } \\
\text { [XEL] }\end{array}$ & $\begin{array}{l}\text { The elite are superior; } \\
\text { the people are inferior. }\end{array}$ & $\begin{array}{l}\text { Discrimination and/or } \\
\text { violence towards the } \\
\text { people. The elite have } \\
\text { special benefits. }\end{array}$ & $\begin{array}{l}\text { Verbal threats or incrimi- } \\
\text { nation of the people. } \\
\text { Justification of criminal } \\
\text { behavior of the elite. }\end{array}$ \\
\hline $\begin{array}{l}\text { Elitism } \\
\text { [EL] }\end{array}$ & $\begin{array}{l}\text { The people are a } \\
\text { homogenous group > } \\
\text { exclusion of the in- } \\
\text { group: The in-group is } \\
\text { ignorant and tends to } \\
\text { make poor choices. The } \\
\text { out-group (the elite) } \\
\text { knows what is right. }\end{array}$ & $\begin{array}{l}\text { Elitists have a distance from } \\
\text { the people; they are not a } \\
\text { part of the people. } \\
\text { Identification with an (elite) } \\
\text { out-group, who knows } \\
\text { what is right. (Exclusive, not } \\
\text { everybody belongs to the } \\
\text { people.) }\end{array}$ & $\begin{array}{l}\text { The people are referred to as } \\
\text { "them". Elitists say what they } \\
\text { think is good for the people. } \\
\text { They speak to or over the } \\
\text { people with arrogance; the } \\
\text { people do not understand } \\
\text { politics. }\end{array}$ \\
\hline $\begin{array}{l}\text { Pluralism } \\
\text { [PL] }\end{array}$ & $\begin{array}{l}\text { The people are a } \\
\text { heterogeneous group }> \\
\text { inclusion. The people } \\
\text { consist of different } \\
\text { groups that unite if } \\
\text { interests coincide and } \\
\text { compete if interests } \\
\text { collide. }\end{array}$ & $\begin{array}{l}\text { Pluralists identify with a } \\
\text { part of the people. They } \\
\text { know their own group and } \\
\text { communicate with other } \\
\text { groups. (Inclusive: } \\
\text { everybody belongs to the } \\
\text { people). }\end{array}$ & $\begin{array}{l}\text { The people are referred to as } \\
\text { "me," "you" and "we" in the } \\
\text { sense of working together, } \\
\text { not being the same. Pluralists } \\
\text { speak as part of one group to } \\
\text { other groups. They speak } \\
\text { with the people. }\end{array}$ \\
\hline $\begin{array}{l}\text { Populism } \\
\text { [PO] }\end{array}$ & $\begin{array}{l}\text { The people are a } \\
\text { homogenous group > } \\
\text { exclusion of the out- } \\
\text { group. The in-group are } \\
\text { the real people; they are } \\
\text { good and know what is } \\
\text { right. }\end{array}$ & $\begin{array}{l}\text { Populists identify with the } \\
\text { people; the populist is "one } \\
\text { of us" and knows what is } \\
\text { right "for us." Distance } \\
\text { from the out-group, who is } \\
\text { unfair and/or do not know } \\
\text { what is right. (Exclusive) }\end{array}$ & $\begin{array}{l}\text { The people are referred to as } \\
\text { "we" in the sense of populists } \\
\text { being the voice of the people, } \\
\text { saying what the people think, } \\
\text { in the language of the people. } \\
\text { The out-group is "them." }\end{array}$ \\
\hline $\begin{array}{l}\text { Extreme } \\
\text { Populism } \\
\text { [XPO] }\end{array}$ & $\begin{array}{l}\text { The people are } \\
\text { superior; out-group(s) } \\
\text { are inferior people. }\end{array}$ & $\begin{array}{l}\text { Segregation from and } \\
\text { discrimination of out- } \\
\text { groups. Deportation/ } \\
\text { exclusion of out-groups } \\
\text { from the country. }\end{array}$ & $\begin{array}{l}\text { Justification of discrimination } \\
\text { and deportation. Accusing of } \\
\text { the out-group of lying. }\end{array}$ \\
\hline
\end{tabular}

Table 3.3 Rubric of the political style-element The people. 


\section{I Donald Trump.}

On the ideational level of the people Trump shows a mixed style with pluralist, populist and extreme populist elements, resulting in an average populist style score. A populist element is, for instance, the expression that a president does not need to have special skills: "I mean, who is not qualified. Everybody is qualified. We are all qualified, right?" $(8,25: 50)$. This quote is populist because it suggests that the people are capable of self-governance.

An extreme populist style is visible in this quote: "By the way, we have the smartest and most loyal people, are in these rooms. The Trump-people are the smartest and they are by far the most loyal" $(8,38: 05)$. This is extreme populist because it states that the people are superior, better people than the out-group. Furthermore, Trump sometimes tends towards pluralism: his notion of "the Trump-people" in the above quote displays consciousness of various groups of people. This is also visible in the following quote:

But we have a tremendously divided country; white and black and everything, we have young and old. Everybody is at odds. There is tremendous division, because

Obama is a tremendous divider. He divides, and he has done nothing for AfricanAmerican people. $(8,43: 25)$

The quote is marked as mixed pluralist-populist, because it shows that eventually Trump thinks of the people as conceptually one (populist) because the corrupt elite is responsible for dividing the people.

On social level Trump acts as a populist, in Pennsylvania relaying that he is one of us: "I went to school in Pennsylvania, I guess I am a product of Pennsylvania, I love Pennsylvania" $(8,7: 40)$. In New York he states that he has New York values and is a typical New Yorker (7, 20:12). Trump admits that he used to be a part of the political elite, but now he is one with the people. He literally says he is "a worker, and you are workers too" $(7,1$ I:59) and that he is not with "the bosses" anymore $(7,53: 45)$. Clearly, "the bosses" do not belong to the people, but Trump does. In addition to these populist utterances, Trump's extreme populism is apparent when he dispels an anti-Trump supporter from his rally (7, 7:57- 9:47). The total score for this element, however, is marked as populist because Trump defended himself with his first amendment rights, suggesting that he wants to stay within democratic lawful boundaries. Furthermore, he does not ban the press here; he stirs the people against 
them, but that is a matter of rhetoric or presentation; on social level his overall style towards the people is populist.

On a presentational level Trump scores extreme populist. He is a plain populist speaking in the voice of the people: "And it is 'we,' I am the messenger, and I am a good messenger but I am just the messenger. It is about YOU” (7, 23:08). However, he is extreme populist when he stirs the people against out-groups (migrants, the media, other politicians) and accuses them of lies and terroristic activities: "The dishonest press, world's most dishonest people. They cover it wrong all the time" $(7,50: 28)$, and:

And then you have people coming from the migration; thousands and thousands of people are coming here, nobody even knows where they're going, they put them all over the country. Nobody knows. Are they ISIS? It could be the great Trojan horse. Nobody knows. We'll build a wall, don't worry about it. We will build a wall, it is gonna get built. $(7,6: 00)$

On average Trump scores populist on three levels of the style trait the people.

\subsection{Hillary Clinton.}

On the ideational level, Clinton expresses the pluralist vision that society consists of different groups, who work together because they have common interests: "I am focused on the issues that really matter to everybody. To some an issue or two might be more important than others, but if you look at them all, they are interlocking and intersectional” $(6$, 22:58/34.73).

On social level Clinton shows being in contact with a lot of people. Sometimes she is pluralist, saying that she and the people are "partners" in politics: "I will work my heart out for the people here in Northeastern Pennsylvania. I will be a good partner because we have work to do" $(5,14: 05)$. Sometimes she displays that she is just a normal person, when she speaks of "we" going to the supermarket (populist), but also involved with her black and Latino friends (pluralist):

There is no woman's discount when we go to check out at the supermarket counter. I have been shopping a long time, and I have never been looked at by a cashier and 
said, ok you are a white woman. You only have to pay $\$ 0.78$. Or my friends, you are a black woman, you are a Latino woman, you do not have to pay the full freight. (5, 27:28)

When she expresses that she is one of us, this is not always convincing on social level because she appears far too busy to really socially be one with the people:

I stopped in Scranton on my way here. I always feel so much at home. I stopped at Casa Bella restaurant. But I was running late so my planned dinner was kind of abbreviated, but I said hello to a lot of people there, and I met people who said things to me like, I knew your cousins. I knew your uncles. I had one man say; didn't we sled down Court Street one winter? I said, could have been. Could have been. I was there. $(6,12: 10)$

Because of her presentation as a busy politician, her style on social level is pluralist-elitist and not pluralist-populist, as it would have been if she had shown taking more time for people.

On a presentational level, Clinton's style is sometimes populist (as shown above), but most often pluralist, leading to a mixed populist-pluralist style. She sometimes refers to the people as "you" and herself as "I," sometimes as "we" in the sense that she works together with the people:

You sent me to the Senate. We worked together. We dealt with the horrors of $9 / 11$ together. We worked to bring opportunities to inner-city areas and upstate rural areas and it was the greatest honor of my life to represent you in the Senate and I want you to know that New York had my back and I always tried to have your back and I will again if I am so fortunate enough to be elected your president. $(5,22: 00)$

On the three levels together, Clinton shows an average pluralist style. 


\subsection{Bernie Sanders.}

On the ideational level, Sanders has a mixed populist-pluralist style. He is populist because he states that the people, not the elite, know what is right. They have to think outside the boxes, because these boxes represent the status quo of the elite. This contains an opposition of an in- and an out-group, of the people as a unity against the elite (politicians, corporate America, Wall Street and media):

Here is my point. The major crisis we face, are not that crises themselves, it is the belief told us every single day by the establishment, by the media, by Congress, you cannot make change. This is the status quo, the way it is, and the way it always will be. It does not matter what you believe -- and that is what this campaign is challenging. $(4,1: 00: 23)$

However, the people also consist of different groups, with different interests, potentially resulting in tensions, but with common interests they can work together (pluralist):

What this campaign is about, is the understanding that when we stand together, black, and white, and Latino and Asian American, and Native American. When we do not allow the Donald Trumps of the world to divide us up, there is nothing we cannot accomplish. (3, I:17:00)

Noteworthy is that Sanders (like Trump) points at his opponent as the cause of the division: it means that the people are conceptually unified after all. However, because Sanders sees the strength of the people in their diversity, it is still a pluralist notion of a united people rather than the people as one body:

And if we do not allow the Donald Trumps of the worlds to divide us up, if we understand that our strength is in our diversity, and if we stand together, and if we demand a government that represents all of us, and not just the I\%, when we stand together, there is nothing that we cannot accomplish. $(4,1: 05: 04)$ 
On social level, Sanders is also mixed populist-pluralist. He is populist presenting his family as a prototype of the American family, identical with "millions and millions of families all over this country" (3, I:44:00). He often refers to people as "our brothers and sisters" (3, I:49:39 - I:53:42), indicating that he sees the people as one big family (populist), albeit a very diverse family (pluralist).

On a presentational level, Sanders' style is mixed pluralist-populist. He often says that "we" or "this campaign" are listening to many groups of people (pluralist):

We are listening to brothers and sisters in the African-American community (...) This campaign is listening to our brothers and sisters in the Latino community. (...) This campaign is listening to people whose voice is almost never heard, and that is the people in the Native-American community. (...)This campaign is listening to young people. $(3,1: 49: 39$ - I:53:42)

At the same time he often directly tells what the people know and feel, and in doing so he is a populist voice of the people: "You are tired and I am tired of seeing those videos on TV of unarmed people being shot by police officers." (3, 2:04:30)

$\mathrm{He}$ also lets the public say what he thinks (apparently the public already knows what he is going to say). This shows that he is one with the people: "What people say, they say 'Hey Bernie, you're thinking too biiiig' (accent). Your ideas are just, just ... [crowd yelling 'Huuuuge'] (Sanders laughting) yes, your ideas are too Huuuuuuge ... I don't think so” (3, I:57;30).

On average, Sanders has a mixed populist-pluralist style on the people.

\subsection{Conclusions of the Analysis.}

The overall results of the analysis are displayed in Figure 3.I, including the other four political style traits, not elaborated on here. The figure shows that Trump's style can be characterized as populist, Sanders' style as mixed populist-pluralist and Clinton's as mixed elitist-pluralist. Looking at their styles in more detail contributes in many ways to a better understanding of the political situation, of which I mention two.

First, Trump and Sanders share a populist profile, however, on four of five traits they differ in sub-categories. They only come close in their conception of politics: both see politics 
as conflict. Yet, there is another similarity: they both blame their political opponent for dividing the people (Trump blames Obama and Sanders blames Trump). This can explain why they both aroused strong feelings amongst their followers; they both instilled the belief that their followers were the only ones seeing it right. This is more powerful than the pluralist standpoint that different groups always have different interests, or the elitist position that the people do not really understand politics anyway.

Second, looking closer at the difference between Clinton and Sanders shows that, despite both being Democrats, their style difference is larger than that between Sanders and Trump. They differ most in their conception of politics: one seeing it as conflict, the other seeing it as working together. Only on one trait (the people) Clinton scores not as an elitist. However, the question is whether the audience believes Clinton's bond with the people, because although she presents herself as one of us on presentational level, her performance on social level tells that she is far too busy for that. This inconsistency can be an explanation for the media describing her appearance often as unauthentic.

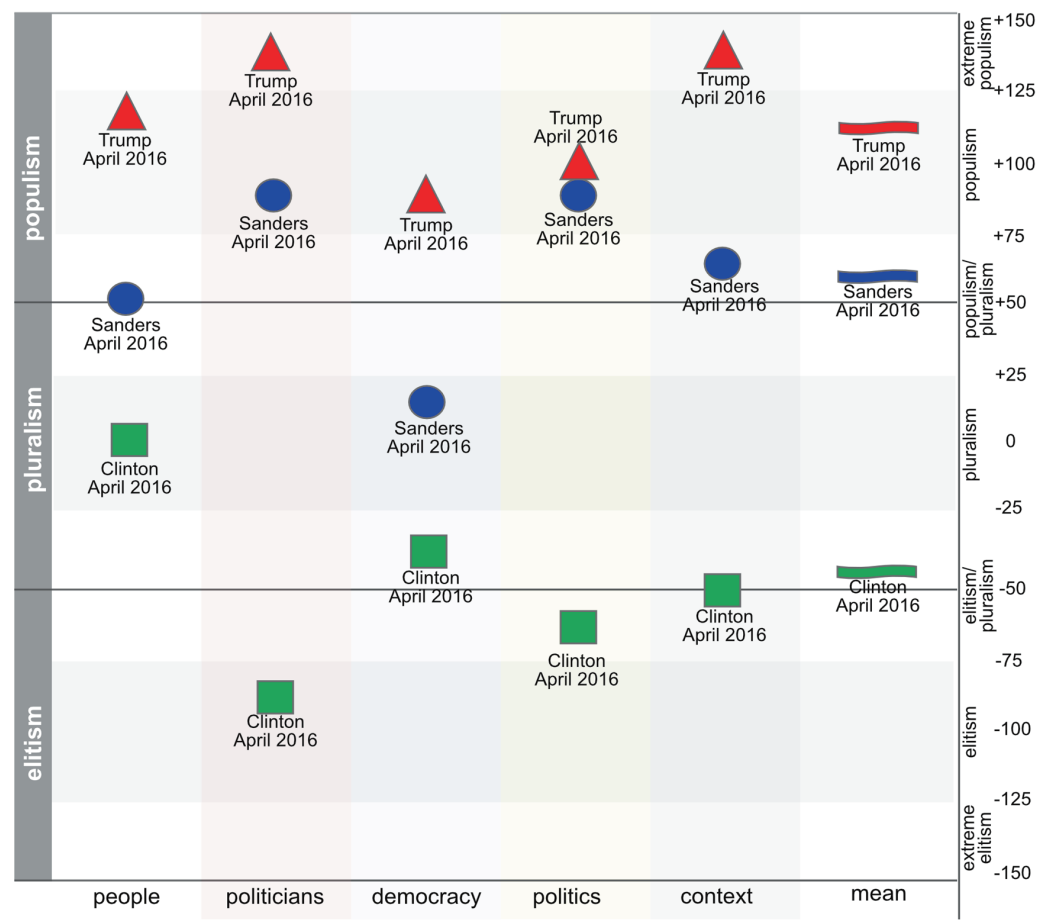

Figure 3.I Political style in total and on five traits separately, of three candidates in the US primaries, April 2016. 


\section{Conclusion and Discussion}

This chapter defines political style as "a stylized political performance purposed to fill the 'aesthetic referential gap' with a political identity”. Political identities are complex because they are assembled through expressions in three dimensions: the social dimension (the coconstruction of identities in interaction with others), the ideational dimension (the fragmented expression of ideological thought) and the presentational dimension (presentation through language and other means).

Through conceptual analysis with help of the theatre metaphor, five traits of politcial style are defined: the people, politicians, democracy, politics, and the context. Comparing differences on these traits with existing style labels, shows that populism, pluralism and elitism position themselves on all five traits and three dimensions, to form a balanced scale upon which political style can be measured.

Although the performed analyses in this chapter explain important parts of the performances of Trump, Sanders and Clinton, to get a more complete picture political style analysis can be complemented with analysis of rhetorical and social styles. Rhetorical styles can be defined using classical rhetorical theory complemented with modern metaphor theory, as applied by Charteris-Black (20II, 20I4) and in Chapter 7. This way the link between rhetorical and political styles can be studied further, in the same manner Hariman (1995) linked rhetorical features to his four political (social) styles, or as in Chapter 8 of this dissertation.

Furthermore, to compare political style with context dependent social styles, labels can be abstracted from social contexts. For instance, Moffitt's technocratic style, Canovan's pragmatic style, and the earlier mentioned elite style, or notions such as a globalist vs. a localist style can be used to develop a more elaborate range of social styles. As said, the number of social styles can vary endlessly, but it would be interesting to see how context related social styles link to the more abstract political styles of politicians.

Although the performed analysis of US presidential candidates only shows two mixed style forms (populism-pluralism and pluralism-elitism), it does not deny the existence of the third combination; elitism-populism. Returning to Pim Fortuyn; although he is generally seen as a populist, he sometimes used a mixed populist-elitist style: "In my campaign not only politics get a whipping, I also come down hard on the citizen. Worthless politicians but also worthless citizens" (as cited in Pels, 2003a, p. 52). Fortuyn is not the only one using a mixed 
populist-elitist style; it reminds of a traditional Dutch social style: the Calvinistic reverend ${ }^{9}$ dooming the people as well as politicians for not listening to God. It is for instance the style of Reverend Zandt in 1946, a parliamentarian for the Dutch Reformed Party (SGP): "Currently the word 'progressive' is very popular amongst the masses of the people. It is music in the ear of many voters. It is the syrup that is used to catch the voters like masses of flies" (Speech 21 , p. 68). ${ }^{10}$ This quote is taken from a longitudinal investigation into ideological and rhetorical style changes in Dutch politics, for which the PEP-Index is originally developed. Although this research is still in progress, first analyses show that the PEP-index is useful in both the US and in the Netherlands, and therefore probably in other modern representative democracies as well. This suggests that the instrument is suitable for national and international comparison of styles over a longer range of time, as well as for more detailed analysis presented in this chapter; further research has yet to show if this is the case.

While this approach assembles theories from different disciplines, the guidelines offered by Critical Discourse Studies made it possible to avoid eclectic failures such as mixing up seemingly similar concepts (i.e. Weiss \& Wodak, 2003). A considerate interdisciplinary approach not only introduces new and insightful perspectives to the political realm, it also provides an awareness of the multivalence of concepts such as ideology and style.

It might be argued that populism, elitism, and pluralism cannot be split up into sections which allow the styles to be mixed; it is the specific combination of features that makes them what they are. Nevertheless, as politics is an art, as suggested by political and rhetorical theorists (i.e. Ankersmit, 1996; Hariman, 1995; Pels, 2003a)) mixing styles is to be seen as a creative act. Political actors artistically combine theatre costumes of different styles; choosing a populist hat with an elitist gown and pluralist shoes. This sectional view on style provides more meaning than pure, unalterable labels of populism, elitism, and pluralism,

$9 \quad$ Not to be mixed up with the (context dependent) style of American Reverends, like Martin Luther King's, which is a completely different social political style.

10 Original Dutch: “Dit woord 'vooruitstrevend' is thans bij de groote massa zeer in trek. Het streelt het oor van menigen kiezer. Het is de stroop, waarmede men de kiezers als vliegen bij menigten vangt." Translation by author. 
mostly because politicians seldom see themselves as elitist or populist, but they might admit that they have populist or elitist traits.

In this chapter, this approach shows its value through the comprehensive view of the separate style traits and the possibility to compare politicians on such a detailed level. It helps to identify precisely which traits a particular style consists of. This is essential to know, because when it comes to performing on the political stage, it is often the smaller, cursory stylistic detail that makes the difference. 


\section{4 \\ Probing into Populism's Core}

\section{An Analysis of the Deep Semio-linguistic \\ Structure of Populism}

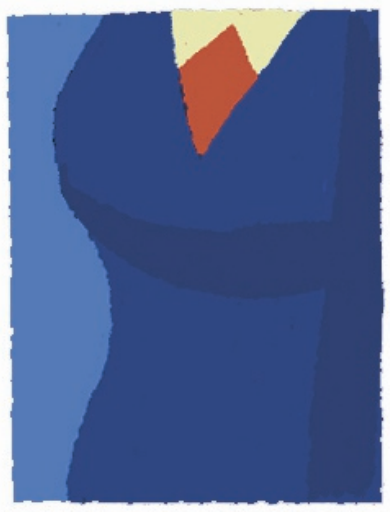

This chapter is a minor revision of: Schoor, C. (2020). Probing into populism's core: An analysis of the deep semio-linguistic structure of populism. Critical Discourse Studies. DOI:

10.1080/17405904.2020.1769698. Parts of this chapter have been presented at the conference: Logics, Critical Explanation, and the Future of Critical Political Theory: Applying Discourse Analysis in Multiple Contexts, May 3 I - June I, 2019. Essex University, Colchester, UK. 
It is not us who speak the language, it is the language that speaks in us. We bathe in language as a social reality: in a sense language is society. Algirdas Greimas, Discussing Language, p.70.

\begin{abstract}
This chapter analyzes populism utilizing the semiotic theory of A.J. Greimas. This structural linguist offers a tool for uncovering links between manifestations of populism and the language structure that makes these manifestations possible in the first place. The (post-) structural analysis in this chapter brings together different approaches to populism, through revealing one shared underlying structure. This core-structure of populism connects three framings of populism that all come with different populist features. The core structure also sheds light on the dispute regarding whether or not a homogeneous people is integral to populism. The underlying structure precisely depicts the logical steps from individualism to populism that Laclau describes in his definition of populism as an act. Whereas Laclau's definition does not include a homogeneous people, the structure reveals a short-cut to populism, which does comprise a homogeneous people. Hence, the deep structure of language facilitates two versions of populism, one with a homogeneous people, and one with a non-heterogeneous, unified people.
\end{abstract}

\title{
I Introduction
}

Many politicians cannot be clearly placed either in or outside of the populist family. Jeremy Corbyn, for instance, is not considered populist in Mudde's broadly used definition (2004, 2017) because his notion of the people is not a homogeneous one. Conversely, Mouffe argues - based on the definition of populism that she developed together with Laclau (Laclau, 2005a; Laclau \& Mouffe, 200I; Mouffe, 20I8a)—that Corbyn can be regarded as a populist, on the grounds that he creates a synergy between various social struggles and assembles these as an us against a them (20I8b, 20I8a, p. 38). Within the Laclauian definition of populism, however, Corbyn's characterization as populist is also discussed. For instance, Prentoulis \& Thomassen (2017) dispute that Corbyn succeeds creating a real unity of heterogenous demands, and Katsambekis and Kioupkiolis (2019, p. 9 of 55) hold Corbyn to 
be a "borderline case" of populism. Maiguashca and Dean (2019) argue that Corbyn's characterization as populist is only possible when the populism concept is stretched "so far as to render it meaningless," defining all oppositional politics as populist (20I9, p. 2 of 5I).

Contested populist cases such as Corbyn's are not restricted to the left, as seen in the case the of right-wing Dutch nativist Thierry Baudet. His party program resembles that of the Dutch populist and right-wing nativist politician Geert Wilders. Like Wilders, Baudet is against immigration, the EU, and "climate nonsense," and wants more money for the security, education, and healthcare of the Dutch people. Unlike Wilders, Baudet presents himself as an elite member, having a doctoral degree and an upper-class image. He stresses the importance of high culture, such as classical music and literature (see Chapter 6 and Rooduijn, 2019). Rooduijn explains Baudet's political performance as a combination of straightforward populist ideas and an elite political style. In line with Mudde's definition of populism as a set of ideas, Rooduijn argues that Baudet's deviation from the populist low does not make him less populist, because a low presentation does not belong to populism's core (c.f., Rooduijn, 20I4). In Ostiguy's definition of populism, however, a low presentation is central to populism (2017) and Baudet's evident use of high culture contests his populism (only his nativism counts as low in Ostiguy's definition). In Moffitt's (2016) definition, Baudet is also only partly populist: he is not populist as he does not display bad manners, but he is populist in how he proclaims a crisis and exploits the antagonism of the people versus the elite. The confusion does not end here; according to Weyland's (2017) definition he does qualify as populist: Baudet often speaks directly for the people, identifying with them, such as in this quote: "So we will finally become the boss of our own country again." (Speech 28, 00:19:00). This populist twist, in which power goes ultimately to the leader and not to the people, differentiates populism from leaderless grassroots movements-movements that are, to make the confusion complete, considered populist by both Gerbaudo (2017) and Aslanidis (20I8).

This chapter contributes to a better understanding of these disputed cases of populism by using the lens of the semiotic theory developed by the structural linguist A.J. Greimas (1970/1987, 1970/199I). Greimas' systematic approach to unraveling the structures behind language offers a tool that can reveal links between the inductive features of populism and two underlying discourse structures. Greimas' method is explained in section 3. Sections 4 and 5 present a Greimassian analysis of populism in opposition to other concepts. The analysis demonstrates that populism, elitism, and pluralism share one core 
structure, intertwining the three concepts in three oppositional dimensions. This core structure is not restricted to populism, elitism, and pluralism; populism in relation to other collectivisms shows the same underlying structure. In the ideational dimension, the opposition is about seeing the people as heterogeneous or not; in the social dimension, it is about being part of the elite or not; and in the presentational dimension, it is about identifying with the people or not.

This structure restricts - not predicts - the possible meanings of populism; different approaches to populism, explored in sections 6 and 7, all have parts (but not necessarily all) of the structure underlying their definitions of populism. The structure displays the steps, described by Laclau, that have to be taken in order to transition from a differential logic into the equivalential logic of populism. Additionally, the map demonstrates an alternative route to populism; a short-cut that leads from individualism to populism in just one step. While Laclau's logically correct route leads to a populism without a homogeneous people, the short-cut does contain a homogeneous people; it transposes an individual logic onto the people and thinks of the people as if it were a person (oneself). This may be not logically correct, but the core structure facilitates the step, for which reason it feels logically correct, allowing a common sense understanding of populism. Hence, the underlying structure at the deepest level of language enables two variants of populism: one containing a homogeneous people, and the other one a united people. What these variants have in common is that both present the people as one, whether they consider it one or not.

Section 8 shows that the core-structure of populism also provides insight into Corbyn and Baudet's respective contested cases of populism; these can be characterized as populist in one dimension, but not-or only partly-in the other two dimensions. Finally, section 9 describes the general conclusions.

\section{Logic Versus Common Sense}

The ongoing debate on the populism concept is often related to whether populism is seen as an ideational, socio-cultural, or political-strategic matter (Kaltwasser et al., 2017). This being a relevant distinction, another difference is just as important: the difference in the method used to analyze populism. Some researchers define populism by using induction-by comparing various populist practices and selecting the ideas that they share as belonging to the populist core (Rooduijn, 20I4). The inductive approach has the advantage that the 
results stay close to the common use of the word populism. For this reason, it is broadly (yet, not unanimously) recognized as a correct definition. Its disadvantage is that it is based merely on intuition; it starts with intuitively selecting populist practices, comparing these, and declaring the shared features to be populism's core. This core is subsequently used to decide whether or not other political practices are populist. Inevitably, this method cannot be more than intuitive, because this is where the induction circle started (c.f., Stavrakakis \& Jäger, 2018).

A second approach defines populism using deduction. This approach seeks factors that predict the rise or decline of populism in society. For instance, populism is explained as a reaction to a crisis, or as economically grounded. The advantage of this approach is that a reasonable explanation for populism is provided based on empirical facts. The disadvantage is that these empirical facts are still based on intuitive features, and that suggested causes can never explain the entire phenomenon, as social phenomena such as populism are too complex to predict.

Lastly, there are the structural approaches; they avoid induction but also reject deduction because this suggests a meaning for populism outside discourse. Alternatively, they "deconstruct" or "retroduct" the underlying logic in discourse. This explains populism rather than predicts (Glynos \& Howarth, 2007; Laclau, 2005a).

Although all approaches together have certainly broadened the academic insight into populism, it has not as of yet resulted in consensus-as shown in the above examples of Corbyn and Baudet. The logical insights into populism are hard to reconcile with the inductively grounded common sense. One might argue that this common understanding is wrong because logic is always right, however, the question is not about right and wrong; all expressions and narratives, including logical ones, are part of discourse-of which we are trying to make sense. In this light, clashes between logic and common sense are problematic because they reveal that not all structures beneath signification have been taken into account.

For instance, Laclau defines all political discourse as populist to some extent, which goes against common sense that some politics are populist and others not. Although Laclau's explanation of populism is compelling, the common-sense meaning must have a reason as well; one of the tasks of academics is to find this. In the case of Laclau's theory, it is promising that researchers are now working on specifications that can differentiate between different populisms, and on the difference between populism and anti-populism. 
(Stavrakakis \& De Cleen, 20I7; Stavrakakis et al., 20I6). However, clashes between populist logic and common sense still occur, as can be seen in the dispute on whether or not the homogeneous people belong to populism (Katsambekis, 2016; Mudde \& Kaltwasser, 20I2; Stavrakakis \& De Cleen, 20I7; Stavrakakis et al., 2016).

Like the above-mentioned approaches, this chapter looks into the differences between variants of populism and between populism and anti-populism. It differs from the above-mentioned articles in its focus, which is not primarily on populism but on political style, encompassing populism, elitism, and pluralism. In this broader focus, it not only looks for the differences, but also for the commonalities of populism with other political styles.

\section{Greimas}

This chapter aims to connect the logic and common sense approaches to populism, by investigating the concept of populism through the lens of the semiotic theory, as developed by the structural linguist A.J. Greimas (1970/1987, 1970/1991). A Greimassian approach for analyzing populism has some similarities with the so-called logics approach to populism (Glynos \& Howarth, 2007), as well as with Laclau's discursive approach, but there is a major difference. Laclau's, Glynos', and Howarth's origins lie in the social sciences, and so do the origins of the concepts they use. Social science concepts such as hegemony and power are important, alongside linguistic concepts that have been adopted by the social sciences, such as signifier and signified. The latter, however, may have linguistic roots but it is its socialpsychological, Lacanian interpretation to which is referred.

Greimas, on the other hand, is a linguist and approaches discourse from a pure language perspective. Though this angle may seem less appropriate for studying politics, Greimas' analysis tools are useful for the social world as well, as the political realm can all be regarded as discourse. Choosing Greimas' lens for studying populism is helpful for two reasons. First, it provides a different scope, which sheds light upon yet unknown aspects of populism. Second, Greimas' tools establish a connection between three discourse levels that have links with the inductive, deductive, and retroductive approaches to populism-and can, therefore, show how these approaches relate to each other.

Greimas' upper discourse-level consists of manifestations, similar to De Saussure's (1916/2015)) language use. Manifestations of the concept populism are visible both in 
context-dependent populist practices and in the popular use of the word populism. The inductive approach is grounded on this level.

All manifestations have an underlying structure; what De Saussure terms the language system. This structure does not exist immanently from its manifestations; nor can it be reduced to them either. It explains its meaning on a more abstract level. Greimas distinguishes two levels to this underlying structure.

The first is the surface structure, which takes the form of action-based narratives. Laclau's (2005a) characterization of populism as an act has the structure of a narrative. Other populism theories can be regarded as narratives as well, such as Canovan's (I999) explanation of populism as coming from a tension inherent to democracy, or Ostiguy's (2017) explanation of populism as flaunting the low. Mudde's (2004) static definition of three core features can also be formulated as a narrative, in which the people claim to take power back from the elite because they express the general will of the people. All narratives include action and time. They can be further analyzed at their action structure using Greimas' actantial model (Greimas, 1970/1987), or-as this chapter does-used for further analysis of the deep discourse structure.

The second structure level, the deep semio-linguistic discourse level, is based on oppositions between words. Here there is no action, just concepts relating to each other. This deep structure restricts the possibilities of the manifestations and narratives of populism. Many populism theories analyze populism in opposition to other concepts. Hence, parts of this deep structure are already mapped, but the whole picture remains a puzzle with missing pieces. To be clear; this deep structure is not static, as it is also part of discourse. As the meanings of concepts at the manifestation level change over time (Culler, 1976; De Saussure, 1916/2015; Skinner, 1999), these changes also affect the deep structure, yet only marginally and at a much slower pace, as it is the deep structure that makes these new manifestations possible in the first place.

In order to analyze the deep structure of language, Greimas devised a tool: the semiotic square. The tool breaks the meaning of a word down into binary oppositions, thereby revealing the underlying logic. The Greimassian square has been criticized as being reductive and invalidating the subjectivity of the interpreter's framework, but this critique has been countered as an overly-narrow reading of Greimas' work (Chandler, 2002, p. I2I; Hébert, 2019, p. II; Parret, 1989; Schleifer, 1987, p. 164). Greimas sees the possibilities for new manifestations as endless, but suggests these manifestations are still produced from a 
limited set of rules (Parret, 1989). Greimas has also suggested that his tools are open for a more flexible application, connecting semiotic squares with each other (Felluga, 20I5, p. 125; Greimas, 1970/1987, p. 60). This chapter applies the semiotic square flexibly, connecting multiple squares to reveal hidden framings. A semiotic analysis never shows the true meaning of populism (which does not exist) but always just one framing of it. Connected squares show other possible meanings, which were neglected or repressed when using one frame instead of another.

\section{The semiotic square of A.J. Greimas \\ On the left, the original square with the word 'white' in opposition to 'black' . On the right, a flexible application of the quare, revealing the framing of a word by placing it in opposition to multiple words, used in different moments of time.}
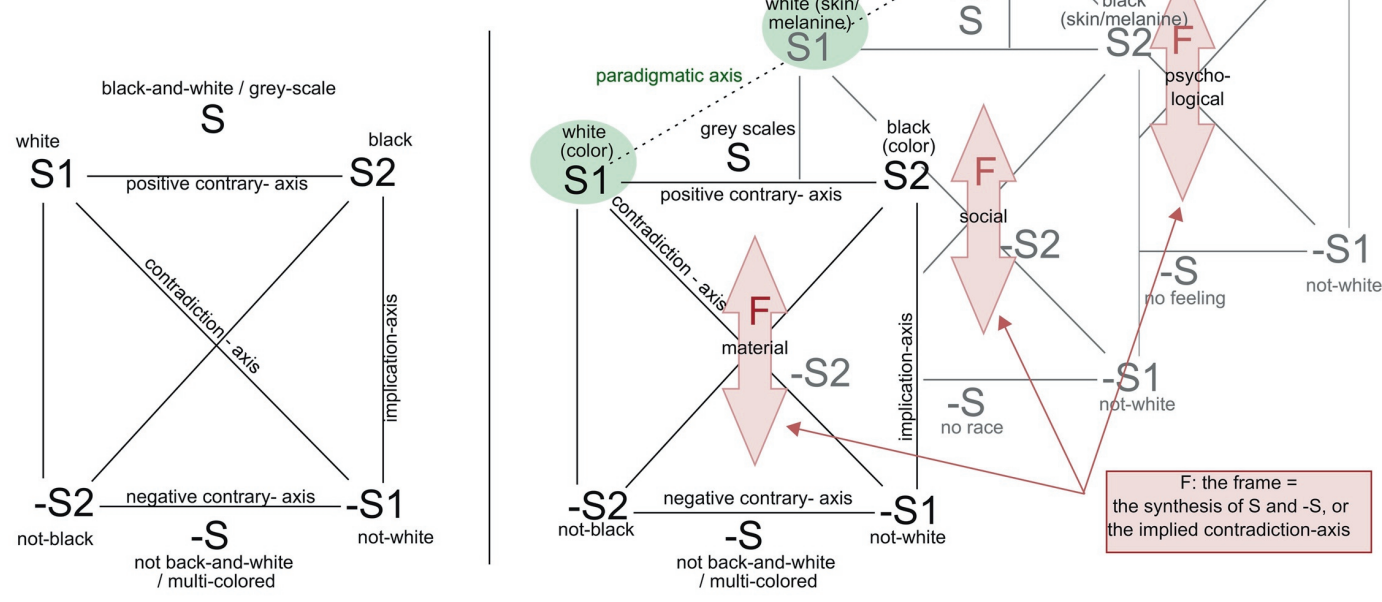

Figure 4.I The semiotic square of A.J. Greimas in a flexible application.

Figure 4.I demonstrates this flexible use of the semiotic square with the opposition whiteblack. White is placed at (SI) of the upper axis of the square (the positive contrary axis), in opposition to black at (S2). Black (S2) implies that it is not-white (-SI) and white (SI) implies that it is not-black (-S2). This results in two secondary oppositions at the diagonal axes: black versus not-black, and white versus not-white. These implied oppositions (SI/-SI and S2/-S2) are broader than the first (SI/S2) because it is not only white that is not-black, but also colors such as blue and red as well. The same applies to not-white: besides black, also other colors are not-white. These two secondary oppositions create a third opposition: 
the negative contrary between not-white and not-black (-SI/-S2). Comparing this with the initial SI-S2 reveals the fourth opposition: the implied opposition of grey scales (S), the synthesis of black and white, and multi-colors $(-S)$, the synthesis of not-black and not-white.

The fourth opposition shows how an interpreter frames white by putting it in opposition to black instead of in opposition to something else. The interpreter is added here as a flexible application of the square (Felluga, 20I5, p. 125; Greimas, 1970/1987, p. 60). Contrasting the same word with different oppositions creates a row of connected semiotic squares. Each square depicts a different framing $(F)$ of white; the synthesis of the implied opposition between $\mathrm{S}$ and $-\mathrm{S}$. White is framed as a material matter (color), a social matter (race), or a psychological matter (feeling). This allows the recognition of differences between connected squares/framings.

\section{Populism Opposed to Elitism and Pluralism}

This chapter focuses on the common usage of the word populism (the manifestation level), as well as on the academic narratives explaining populist practices (the surface discourse structure). At the deepest discourse level of the concept populism, all manifestations and narratives are made possible in opposition with other terms, such as elitism, pluralism, technocracy, individualism, or institutionalism, which are all examined in this chapter. Of course, there are more words opposite to populism. Due to space restrictions, this chapter focuses only on concepts that are needed to explain the core (sections 4 and 5) and relates this core to five populism definitions in the populism literature (sections 6 and 7).

\section{I Populism versus elitism.}

Opposing two concepts is an act that foregrounds certain features of these concepts while neglecting others. The opposition of populism-elitism foregrounds, for instance:

- The elite as an opponent of the people (populism) or as a helper (elitism);

- Political leaders as part of the people (populism) or the elite (elitism);

These features are possible manifestations of a more abstract opposition; some people use them, but not everybody will agree on them. On the left in Figure 4.2, a semiotic square is 
depicted with the elite as helper (elitism) versus the elite as opponent (populism) at SI and S2. This specific opposition is chosen because it is broadly recognized as part of populism (e.g., Aslanidis, 20I6a; Laclau, 2005a; Moffitt, 2016; Mudde, 2017; Weyland, 2017) and elitism (Best \& Higley, 2010; Borchert, 20I0; Engelstad, 20I0; Körösényi, 2010; Mackie, 2009; Schumpeter, 2008). This is mainly to avoid the critique that this analysis is subjective, however, any other opposition-including a contested one-would result in the same structure, as this structure makes all expressions of this opposition possible, not only the uncontested ones.

The semiotic analysis is as follows. Populism and elitism are opposites at the positive contrary-axis of the semiotic square (S2 vs. SI). Populism implies that members of the elite are not the helpers of the people (-S2). Elitism implies that members of the elite are not the opponents of the people (-SI). This results in two diagonal contradictions of the square: populism (S2) vs. not-populism (-S2) and elitism (SI) vs. not-elitism (-SI), and in a third opposition between not-populism and not-elitism. This opposition is broader than the first: not-populism (-S2) can be elitism but can also mean that the elite and the people are not two groups that help or oppose each other. Instead, they are part of the same group. Hence, the constructed opposition between not-populism and not-elitism has a synthesis that the people and the elite are parts of a heterogeneous group. As this is a central feature of pluralism, this concept can be seen as the synthesis of not-populism and not-elitism (-S). With $-\mathrm{S}$ in mind, a shared trait of elitism and populism (S) can be defined as: not a heterogeneous people. To be clear: the people as not-heterogeneous does not necessarily entail a homogeneous nativist people, just as not-black does not mean that something is necessarily white. It can mean a nativist homogeneous people, but can also mean a unified, anti-elitist people as understood by Laclau, or even a people united with the elite, such as in nationalism-as long as they can be seen as one in a minimal sense.

Semiotic analyses of other features of the opposition populism vs. elitism, not depicted here, have the same results. This shows that this structure depicts the analyzed opposition at one abstraction level higher. However, it only works in the same framing, which is revealed by $(F)$. In this case, the framing is ideational: a matter of cognition. The tie between the framing and the specific constellation of pluralism, populism, and elitism works as a mathematical law: if the opposition between populism and elitism results in a common opposite other than pluralism, it means that $\mathrm{F}$ is not ideational, but something else. 


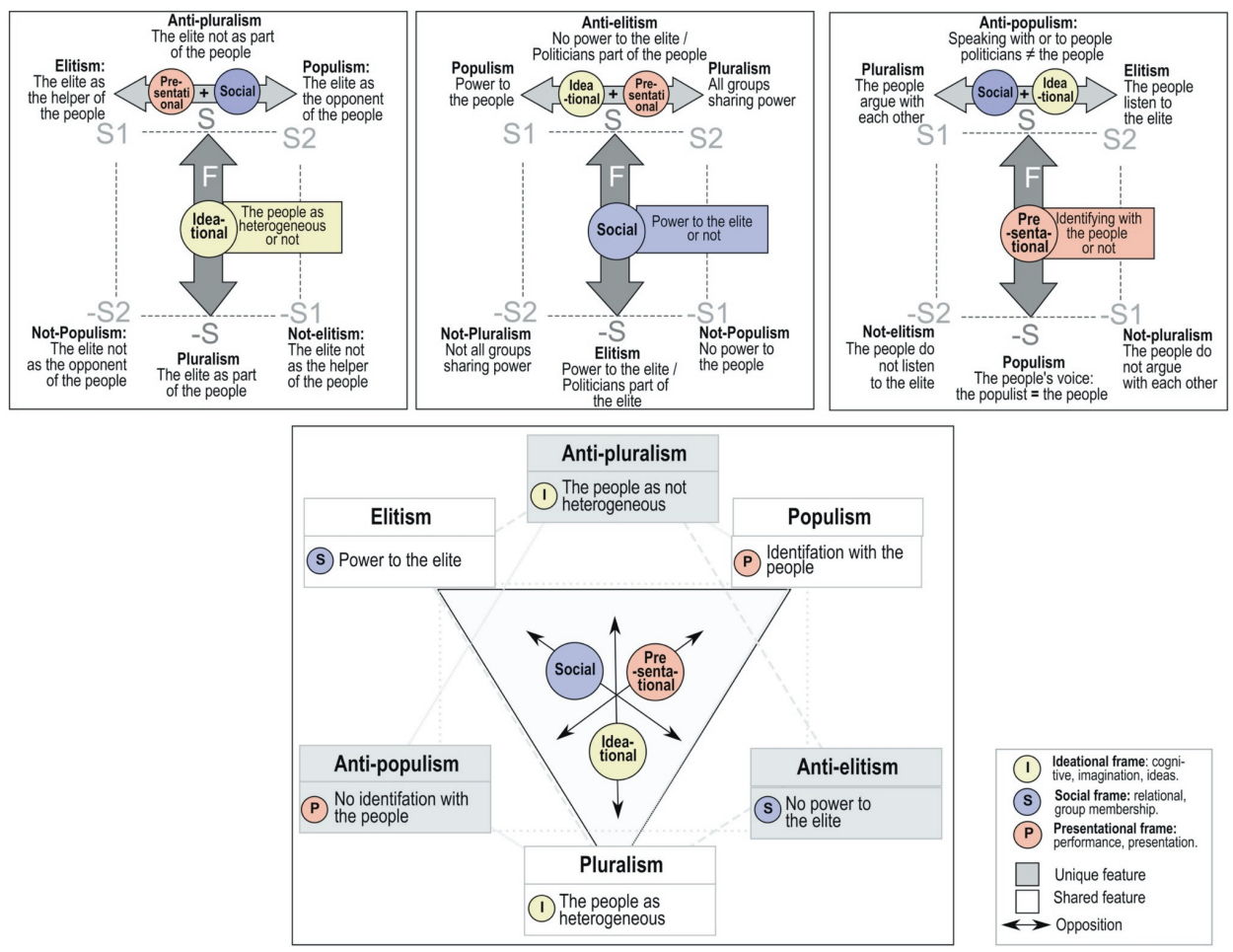

Figure 4.2 Three semiotic analyses of populism, elitism, and pluralism, and the three analyses combined in one core-structure.

\subsection{Populism versus pluralism.}

Opposing populism to pluralism foregrounds features such as:

- Power to the people (populism) versus all groups sharing power (pluralism);

- Proclamation of a crisis (populism) or a nuanced view at the political context (pluralism).

These features come with another frame $(F)$ and hidden opposition (S/-S), as depicted in Figure 4.2 at the upper middle square. The square shows the opposition between power to the people and individuals and groups sharing power at SI and S2: both broadly recognized 
features of populism and pluralism. In this square, populism and pluralism share the characteristic (S) that politicians - whether they claim power to the people or want everybody to share power-do not want the elite to have all power. This feature is opposed to $(-S)$ power to the elite, which is a main feature of elitism. Hence, if populism is opposed to pluralism on the positive contrary axis, it demonstrates elitism as the opposite of what populism and pluralism have in common. The framing $(F)$ is social; it concerns belonging to groups of people, social relations, and power. Elitism implies that politicians belong to the elite, whereas populism and pluralism imply that politicians belong to the people. Again, this meaning of populism only works in a social frame.

\subsection{Elitism versus pluralism.}

Changing the perspective yet again — this time opposing elitism to pluralism at SI and S2reveals a third framing of populism, depicted in Figure 4.2 at the right square. As noted in the literature on pluralism (i.e., Blokland, 20I I) and elitism (Best \& Higley, 20I0; Borchert, 2010; Mackie, 2009; Schumpeter, 2008), this opposition draws the attention at features such as:

- Discussions in society at large (pluralism) versus the people listen to the elite and vote (elitism);

- Politics based on trust (elitism) versus transparency (pluralism).

The square depicts the opposition between discussions in society at large, or more precisely people argue with each other versus people listen to the elite at SI-S2: in pluralism, people stand up for their own rights and are actively involved in politics. Elitists discuss politics with other elite members, while the people watch and vote.

At -SI and -S2, the people do not argue with each other and do not listen to the elite, leading to the definition of $-\mathrm{S}$ as an unmediated relationship between people and politicians; politicians do not need to speak with the people; they instantly know what their people want because they are one with the people. This is a well-known feature of populism in which leaders are the voice of the people. So, in this third semiotic square, populism is the synthesis of the contradiction of elitism and pluralism. Both elitism and pluralism represent and communicate with the people, whereas populists express having an unmediated relationship with the people; they make the people present in the political realm by speaking 
for them. The framing of this opposition is presentational; it is about performance and the question as to whether politicians present themselves as politicians or as the people.

\subsection{Triangular relation.}

Having multiple semiotic squares with populism, elitism, and pluralism at different positions (SI, S2, or -S) —as depicted in Figure 4.2-offers the possibility of linking the squares through the paradigmatic axis, as explained in section 3 (Figure 4.I). Between the three squares, three paradigmatic axes can be drawn, one for populism, one for elitism, and one for pluralism. Putting all connected populisms, elitisms, and pluralisms on top of each other-through a rotation of the squares-results in a triangular model of populism's structure, depicted at the bottom of Figure 4.2.

The three corners of the triangle represent populism, elitism, and pluralism, whereas the sides represent anti-populism, anti-elitism, and anti-pluralism. It is the specific combination of two adjacent sides that defines the corner in-between. For populism, it is the combination of seeing the people as one and defining oneself as a part of the people, implying that populist leaders present themselves as having an unmediated relationship with the people. At its turn, the presentation of an unmediated relationship also defines the other two features. This is because its opposite, the presentation of a mediated relationship, is a defining feature of elitism and pluralism. Hence, three features define the respective cores of populism, elitism, and pluralism, all of which imply each other.

This mutual implication only works from the perspective of the interpreter. Here, the relation between the three dimensions (ideas, social acts, and presentation) is circular; all presentations are also acts and contain ideas, but whereas ideas can theoretically exist just in thought - without being acted or presented — an analyst can only interpret them if they are presented in discourse or action. However, from the perspective of the person who thinks, acts, and speaks, the three dimensions do not imply each other; one can hide thoughts, deliberately choosing not to speak or act upon them. More on this later.

Summarized, the triangular relationship logically requires three dimensions, because the concepts would contradict themselves if the shifting oppositions and coalitions were to occur within just one dimension. The three realms are: 
- Ideational: ideas, cognition, imagination. Here pluralism opposes a united populismelitism in the opposition seeing the people as heterogeneous or not.

- Social: group relations and power. Here elitism opposes a united populism-pluralism in the opposition being part of the elite or not.

- Presentational: the way of presenting, performance, rhetoric. Here populism opposes a united pluralism-elitism in the opposition identifying with (being) the people or not.

\section{Groups, Individuals, and Systems}

The deep structure of language can be imagined as a dense, flexible web in which concepts are simultaneously connected to many other concepts that, directly or indirectly, all influence each other. One concept that strongly interferes with the meaning of populism, elitism, and pluralism, is collectivism as it is the genus to which all three concepts belong. Collectivism directly opposes individualism, and together these two concepts oppose a concept which (in populism theories) is often used as the opposite of populism: technocracy. In this analysis, technocracy is seen as a concept one abstraction level higher than populism. This higher abstraction level also features institutionalism, a concept that Laclau also uses to define populism. The concepts at this abstraction level relate to each other in a similar triangular structure as populism-elitism-pluralism (see Figure 4.3).

Institutionalism figures as the exact opposite of collectivism, as it combines individualism with a belief in systems; the latter is in the real only available in its dystopian version technocracy because systems can never satisfy all individual demands. The 3D visualization in Figure 4.3 makes the relation of the two abstraction levels more tangible. The image shows that institutionalism is situated at the group level without having any group features-which is impossible. This fits with Laclau's characterization of institutionalism as utopian; it can be seen as the utopian opposite of all real collectivisms; populism, elitism, and pluralism. More on this in the next section.

The concepts populism, elitism, and pluralism share the characteristic that they are concepts at the group-level. In the same way that institutionalism is utopian for not integrating a group level into its concept, it is also utopian to have solely features at the group level, such as collectivism in Figure 4.3. The world does not merely consist of groups; individuals relate to groups and use systems to balance group and individual interests. So inevitably, collectivism integrates parts of both the individual and system level into its 


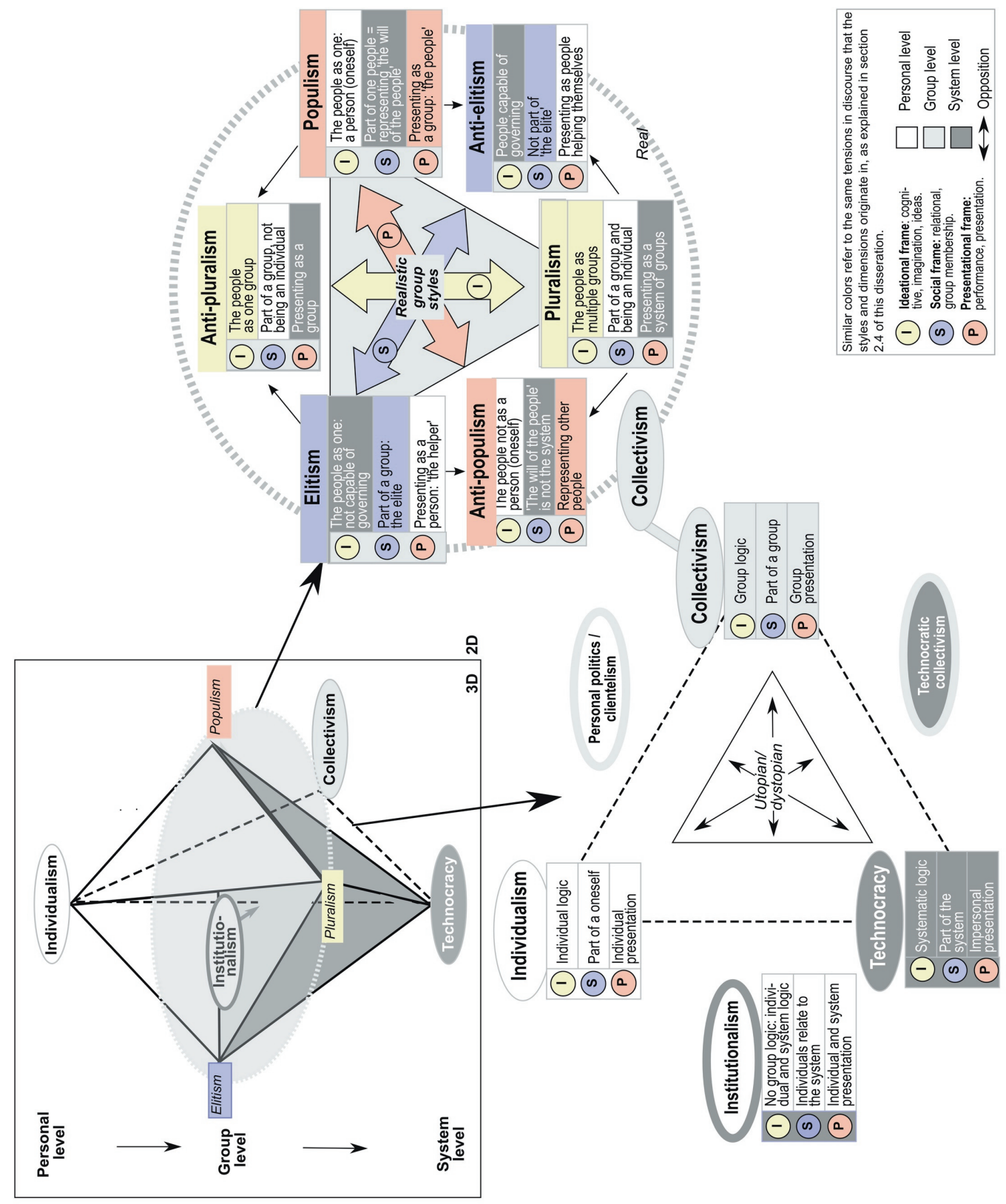

Figure 4.3 Populism as collectivism, in relation to technocracy, institutionalism, and individualism. 
structure. The analysis shows that populism, pluralism, and elitism (and their anti-styles) are all variants of collectivism. They always have one dimension at the group level, one at the system level, and one at the individual level, in a specific pattern. It is the particular combination of levels and dimensions that differentiate them from each other.

In the ideational dimension, pluralism has a full group logic; seeing a group as a collection of individuals that form groups based on their commonalities. Populism, on the other hand, transposes an individual logic onto the group level: it sees the people as a person who acts and thinks as one. Elitism transposes an institutional logic to the group level: the elite governs for the greater good, doing what is best for the country.

In the social dimension, only elitism is fully situated at the group level. Populism combines a group with a system level; being part of the people automatically means representing the will of the people, which equals the system. Pluralism combines a group with an individual level; individuals are part of the people while maintaining their unique individuality.

In the presentational dimension, only populism operates solely at the group level; populists identify with the people, presenting themselves as being the people. Elitism combines a group with an individual level; elitists present themselves as elite members that people can trust; they are not part of the people but act to help the people as elite. Pluralism combines the group with the system level; presenting the system as an objective arbiter between different groups of people.

Summarizing; in addition to the characterization of populism as a combination of 3 dimensions in section 4, this section shows populism as a specific combination of personal, group, and system features in these three dimensions:

- Ideationally, populism combines a group with an individual level: thinking of the people as if it were a person;

- Socially, populism mixes a group with a system level; being part of the people means representing the will of the people; this is the populist system.

- Presentationally, populism operates fully at the group level; populists identify with the people, they are the people in their presentation.

Because the three levels are mixed, all dimensions also become expressions of each other; it is the dominant frame that decides which features are highlighted and which not. 
This structure restricts rather than predicts expressions of populism; the semio-linguistic deep structure describes the ways in which populism can manifest itself. Not all expressions have to use the whole core structure: they can also reflect parts of it, or they can mix parts of populism with elitism or pluralism. For instance, populists who present themselves as saviors of the people logically mix populism with elitism because they place themselves above the people rather than as part of the people. However, if there is another us unifying the people, this can still be considered a coherent populist style.

\section{From Individualism to Populism: One Logical Way and One Shortcut}

This section and the next examine how different approaches to populism, in both academics and common sense, relate to the core structure of populism sketched in sections 4 and 5 starting with Laclau's definition of populism as an "act" (2005a). Laclau explains populism as a reaction to technocracy-the dystopian version of institutionalism. Both technocracy and institutionalism have a differential logic in which the people and the state relate directly to each other, without any groups playing a role. This is visualized at the left side of Figure 4.3; institutionalism, technocracy, and individualism—all opposing collectivism. In Laclau's theory, institutions can never satisfy all individual demands, despite institutionalism's claim that they can. In reality, individual demands get lost in the system. This means that institutionalism inevitably shows itself as a technocracy, in which the system neglects individual needs.

The act of populism starts when individuals realize that their democratic demands are not satisfied. The only way to get satisfaction is by uniting with people who also have unsatisfied demands; though the demands are heterogeneous, the fact that they all remain unsatisfied allows the possibility of equalizing them as one complaint against the people in power. In the figure, this is a move from individualism at the left of the figure towards collectivism in the middle-in Laclau's terms, it is a change from a "differential logic" to a "political or populist logic."

Laclau's populist "act" is not finished with this. As explained in the former section, a pure collectivism is utopian, as groups always consist of individuals, and, therefore, require a system for balancing individual and group interests. So in reality, collectivism always comprises different ways to combine group, individual, and system elements; as in populism, elitism, and pluralism (the triangle on the right of Figure 4.3). On this lower abstraction 
level, individuals adopting a group logic inevitably find themselves at the middle-under position of the triangle - the only variant of collectivism with a group logic-the other two variants respectively have a personal and systematic logic/ideational dimension. In the corestructure it is called pluralism, but this is just a name. Laclau calls it populism to some extent.

In this situation, the multiple demands of small groups must be equalized as one complaint towards the elite. In terms of Figure 4.3, the people must change from pluralism into anti-elitism; unifying the unsatisfied demands under one cause; the elite. Hence, populism in Laclau's definition, projected onto the core structure of Figure 4.3, encompasses only the anti-elitist part of populism, not the anti-pluralist part. From an anti-elitist standpoint, the ideational difference between populism and pluralism is not visible; only the social opposition between the underdog and the powerful, and the rhetorical presentation of the people as one (see the fifth triangle in Figure 4.4). It is still populism but containing only the features that populism shares with pluralism and lacking those that it shares with elitism.

However, this is only valid from the perspective of a person who becomes populist. From an outsider's standpoint (see section 4) the combined logic of being part of the people and presenting oneself as one implies that the people are also ideationally one; perhaps not homogeneous, but at the very least unified so that they can speak as one. Hence, in Laclau's version of populism, the ideational homogenization does happen from the outside, but for insiders the people are still heterogeneous, and homogenization is, at most, temporary.

This clarifies the dispute on whether or not a homogeneous people belongs to populism's core (see section I). The answer is that it depends on whether one looks at populism with an outsider or insider's perspective. Even a group such as Occupy that explicitly expresses its heterogeneity, can-from the outside-still be assessed as one homogeneous group: as, for instance, a chaotic mess or a bunch of lefties, or simply the enemy. At the very moment that a group of individuals starts to use "we," or are referred to as "them," there is at least a kernel of homogenization. This kernel originates in the deepest level of the language system - in the relationship between signifiers; in the difference in between genus and species. In the language system, no individual part (species) of a whole (genus) is exactly the same as the whole; the whole-while consisting of its parts-is also different from it; it has a surplus and lack of meaning. For instance, no actual dog, be it a Cocker Spaniel or a Sausage Dog (species) precisely fits the prototypical genus of a dog, as no species is exactly the same. In the same manner, no individual person (species) precisely fits the genus of the people, and yet, the genus of the people consists of a combination of all 
these different individuals. Hence, the ideational opposition between a heterogeneous and homogeneous people traces back to the formal difference in the language system between species and genus. From the perspective of the species, the people are always heterogeneous, while from the perspective of the genus, there is always a kernel of homogeneity-without it, the genus would have no grounds for its existence.

Apart from this small kernel of homogeneity that lies in every genus, there is yet another linguistic grounds for a homogeneous people to be considered a part of populism. Laclau's process from individualism to populism is not the only available path laid out in the core structure of Figure 4.3. Laclau's way is the logically correct way, that starts with the ideational dimension; changing an individual logic into a group logic. Besides, there is a shortcut that brings one from individualism to populism in a single step; if an individual starts the change towards collectivism with the presentational dimension instead of the ideational, this instantly results in their fitting into the definition of populism provided in Figure 4.3. Keeping an individual logic (ideational dimension) in combination with identifying oneself with the people (presentational dimension) implies that one is also part of the people (social dimension).

So, aside from Laclau's ideational path from individualism to populism, there is a presentational shortcut, that leads directly from individualism to populism. This shortcut involves seeing the people ideationally as oneself, whereas in the logical route the people are only one through implication from the perspective of the outsider, rather than from the view of populists themselves. This entails that a homogeneous people is a possible - but not necessary-result of the discursive act of populism, as much so as a united people; the former begins with the presentational dimension, the latter with the ideational"

I would like to stress that this analysis does not imply any moral justification or rejection of populism: it just shows how language structure facilitates populist reasoning, and that some parts of this reasoning contain a logical fallacy, and others not.

A third possible road from individualism to collectivism starts with the social dimension, changing from seeing oneself as an individual into seeing oneself as part of the people. This road leads to either a homogeneous people, or a unified one. After seeing oneself as part of the people, while keeping one's personal logic there are two possibilities; one is identification with the people, leading to populism with a homogeneous people. The other is realizing that one's personal logic does not apply to the people and, therefore, changing this into a group logic, leading to pluralism. This can further evolve into a Laclauian populism with a unified people. 


\section{Framings of Populism}

This section examines four academic definitions of populism in relation to the core structure of the previous sections. The method used is similar to section 4 ; first, a semiotic analysis reveals the frame of the various oppositions that figure in the definitions. Subsequently, these oppositions are analyzed within the frames of the core structure in order to see how they relate to it. In all four cases, the underlying binary oppositions can be related to the structure of section 4: they may not use the same concepts in opposition to populism, but they rely on or use parts of the same underlying oppositional structures (see Figure 4.4).

Mudde $(2004,2017)$ characterizes populism as pairing up with elitism, together opposing pluralism; this aligns with the ideational frame of the core-structure. Mudde characterizes the difference between populism and elitism as moral, however; morality, as a concept, applies to behavior, not to identity. It is the ideational frame (seeing the people as one) that allows a moral judgement; if the people were not seen as one, a moral judgement would be impossible. Applying morality to groups is, for this reason, not a really moral, but social; dismissing one group of people as not morally fit for government has to do with power. The social dimension here is molded towards the ideational frame. Furthermore, Mudde defines populism as "following the will of the people": this is a social opposition of granting power to the people instead of to the elite. This is made possible, again, by the ideational frame of the people as one. In sum, Mudde uses all three dimensions of section 4, but his main view is ideational, which colors the other features. Morality as a feature of the people is bound to an ideational frame.

Ostiguy (2017) defines populism as "flaunting the low," as opposed to an elitist "flaunting the high." Ostiguy interprets all manners within either a social or a presentational frame. This results in a social-cultural field where the presentational frame is dominant, as well as a politico-cultural field where the social frame is dominant. This way, all ideational features of the core structure are neglected and interpreted as something else. This is not illogical per se: features, and manners in particular, can express multiple dimensions at the same time, and Ostiguy addresses the ideational dimension separately in another analysis. This makes his approach less compatible with the core structure, though it does not defy it either. 

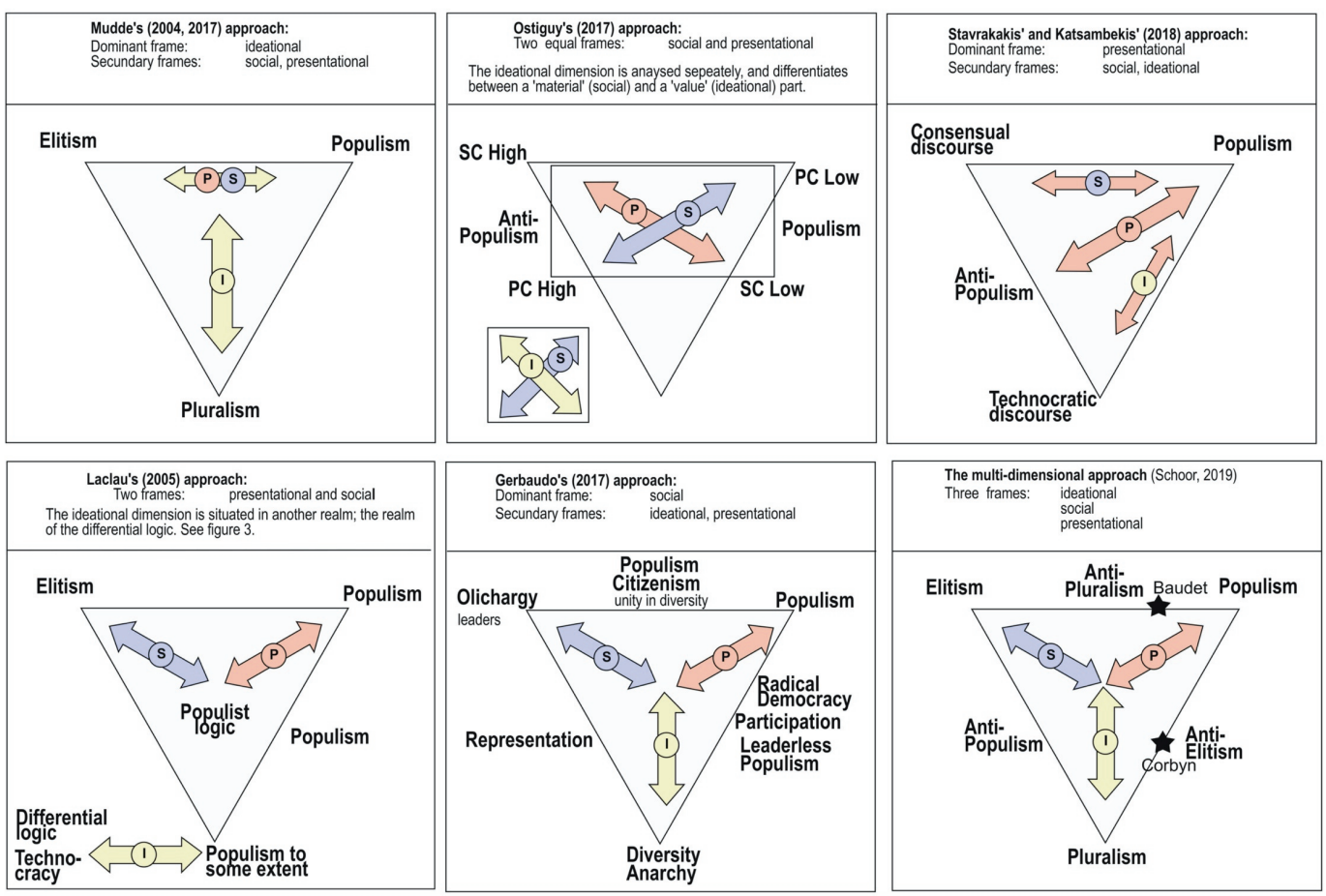

$\leftrightarrow$ Opposition (1) Ideational frame: cognitive, imagination, ideas.

(S) Social frame: relational, group membership.

P) Presentational frame: performance, presentation.

Figure 4.4 The core structure of populism related to different approaches to populism.

Gerbaudo (2017) uses three oppositions that match the three dimensions of the core structure. The ideational opposition is expressed in the difference between a "diverse people" and "Citizenism." The social opposition is visible in the difference between "leaderless, radical democracy" and "oligarchy." The presentational opposition underlies the difference between "representation" versus "participation": participation also allows the people to be present in the political realm, by being directly present as people, rather than through identification with a leader. Hence, Gerbaudo uses the whole core structure, but the concepts at the poles of the oppositions are more extreme than in the oppositions of populism with pluralism and elitism. Perhaps this is a new way in which populism articulates itself in the political realm, or maybe it is just an instable form of populism that will collapse or evolve into more classic populisms, as suggested by Gerbaudo (2017, p. 243).

Stavrakakis and Katsambekis (Stavrakakis \& Katsambekis, 2019) oppose populism to anti-populism. Their main frame is also presentational: whether or not the people are a 
"nodal point," a question which concerns the core-structure opposition between populism and a united elitism-pluralism (presenting oneself as the people or not). Additionally, the "use of technocratic discourse" is opposed to a "personal, populist discourse." This shows a mixed presentational-ideational frame; focusing on language that expresses a system of parts versus a personal whole. Besides, a "consensual discourse" opposed to an "antagonistic, populist discourse" demonstrates a presentational-social frame; the language used to express a cooperation or power struggle. These oppositions all fit neatly into the structure and encompass all dimensions, with the presentational angle coloring the features in the other dimensions.

To conclude this section: each of the above approaches highlights different aspects of populism, and use different opposing concepts; however, they all (partly) rely on the same core structure. This does not mean that all these approaches are compatible; aspects of populism are valuated differently, and different concepts come with different abstraction levels. This leaves much to discuss; this chapter does not pretend to have solved the puzzle of populism, but the introduced core structure maybe of help, as it levels the playing field and makes the used frames visible.

\section{Contested Cases}

The core structure of populism restricts, but not predicts, the possible manifestations of populism. Not every populism will manifest itself in all dimensions, and politicians can combine populist and non-populist elements. This happens in the contested cases of the introduction, Corbyn and Baudet. Speeches from both politicians have been analyzed using a method based on this core structure of populism-elitism-pluralism.

Speech analysis of Corbyn (see Chapter 5) reveals his style as populist in the social dimension. For instance, he presents himself as part of the people: "This was a campaign of ordinary people, like you and me" (Speech 17). Besides, he fights against the elite: "Left to themselves, it is clear what the main Vote Leave vision is for Britain: to be the safe haven of choice for the ill-gotten gains of every dodgy oligarch, dictator or rogue corporation" (Speech 18).

In the ideational dimension, he is mixed populist/pluralist, visible in the above quote in which he depicts the elite as a corrupt homogeny. Additionally, the following quote shows that he depicts the people as heterogeneous (so, not not-heterogeneous): “And Labour was 
the party of unity, bringing generations and communities together, rather than pitting young and old against each other, as the Tories did" (Speech 19).

In the presentational dimension, he often both speaks directly for the people and also expresses his position as with the people; this makes him mixed populist/pluralist. Overall, plotted on the triangular structure in the upper right triangle of Figure 4.4, Corbyn's position is at the anti-elitism side of the triangle, exactly between pluralism and populism. This shows that Corbyn's populism is mostly social. In terms of populism-elitismpluralism, he is best characterized as anti-elitist.

Baudet's populism is different. Speech analysis (see Chapter 6) shows Baudet to be mainly anti-pluralist (see Figure 4.4). Baudet sees the people as a homogeneous group but also mixes populism with elitism; besides being the voice of the people, he also lectures as a professor and strives to build a new elite. This results in a mixed populist-elitist style; a style which seems internally incongruent but makes perfect sense when reviewing the dimensions separately.

Baudet's good manners are elitist in the ideational dimension, expressing the idea that the elite are the helpers of the country, working for the greater good. He combines this with other mixed populist-elitist (anti-pluralist) elements that depict the people as a homogeneous group and express that his own values are not opinions, but the truth. In the social dimension, his good manners can be interpreted as mixed populist-elitist. Not only is Baudet, the politician, a part of the elite (elitist), but the same can also be said for the Dutch people as a whole, or at least according to Baudet; he states that they are descendants of high culture, known for their world-famous painters, writers, and scientists. The not-elite are the non-western, non-white cultures. Hence, Baudet is also part of the (elite) people. This is assessed as populist, which results in a mixed populist-elitist social style. In the presentational dimension, his good manners can be understood as fully populist; they are anti-political class, with the express purpose of standing out in contrast with more mainstream politicians. Due to populist influences, most mainstream politicians in the Netherlands emphasize their status as a normal person, rather than as part of the elite.

The speech analyses of Corbyn and Baudet show that characterizing them as having an anti-elitist and anti-pluralist style, respectively, makes more sense than characterizing them as populist. Both are partly populist and differ substantially from the other, which is evident when looking at their position in the sixth triangle in Figure 4.4. 


\section{Conclusion}

Using Greimas' semiotic tools to probe into populism's core is an abstract exercise; however, the application of it in the analysis of Corbyn and Baudet shows its direct usefulness and confirms the validity of the core structure.

This core structure of populism can be characterized as a combination of viewing the people as not-heterogeneous and political leaders as part of the people. Neither feature is unique to populism, as populism shares the former feature with elitism and the latter with pluralism; it is the combination of these two features that makes populism unique, because it implies a third feature: an (as if) unmediated relationship between political leaders and the people. If the people are one and the populist is part of that unity, the populist has an unmediated knowledge of what the people want.

The core structure of populism can be compared to the grammar of a language; a native speaker will not directly need it, but it can help them to interpret unclear utterances - for instance when a comma changes the meaning of a sentence, or, in the case of the grammar of populism, when politicians mix styles. It also explains how utterances are facilitated by the language structure, be they logically correct or not. In this chapter, the structure shows that a minimally homogenized people-even if only temporary-is part of populism's core. Besides, it demonstrates that the idea of a fully homogeneous people is not a necessary element of populism, and that it contains a logical fallacy, but that it is nevertheless a direct expression of the ideational opposition underlying populism. 


\section{5 \\ Caught Between Populism, Elitism, and Pluralism}

\section{A Method for Political Discourse Analysis}

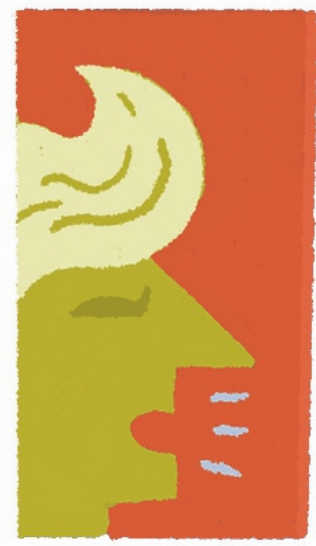

This chapter is a minor revision of: Schoor, C. (in press). Caught between populism, elitism, and pluralism: A method for political speech analysis. In M. Kranert (ed.), Discursive approaches to populism across disciplines: The return of populists and the people. Basingstoke, UK: Palgrave Macmillan. Parts of this chapter have been presented at the conference: Political Discourse - Multidisciplinary Approaches \#2: New discourses of populism and nationalism, June 21-22, 2018. Edinburgh Napier University, Edinburgh, UK. 
We are able to understand the many social and political functions of ideologies only when these fundamental sociocognitive and discursive dimensions of ideologies are made explicit. Teun van Dijk, Ideology and Discourse, p. 24

\begin{abstract}
This chapter outlines a method for comparative political discourse analysis and its application to a set of political speeches of American, British, and Dutch politicians. The method draws on Van Dijk's (1998, 2013) multidisciplinary approach to ideologies and on a semiotic analysis revealing a logical framework behind the concepts of populism, elitism, and pluralism. Populism connects to elitism and pluralism in three dimensions-the ideational, social, and presentational-following the same logic: one of the three concepts always linearly opposes the shared features of the other two. This three-dimensional structure implies that all three phenomena have related features. Together, these features demarcate whether political discourse displays a populist, elitist, or pluralist style, or something in between. Based on this logic, speeches of various politicians can be analysed, plotted on a triangular field, and compared.
\end{abstract}

\title{
I Introduction
}

The question What is populism? is one of the most debated issues in political science. The various existing approaches have recently been (re-) categorized into three mainstream ones: (I) The ideational approach, (2) The political-strategic approach, and (3) The sociocultural approach (Kaltwasser et al., 20I7). The ideational approach views populism as a set of ideas in which politics should follow the general will of the people, and society is divided into two homogeneous and antagonistic groups: the pure people versus the corrupt elite (Mudde, 20I7). The political-strategic approach accentuates the role of the leader and sees populism as a strategy to mobilize the people against the elite group in power (Weyland, 2017). According to Weyland, the ideational approach misses the specific "populist twist"the identification of the people with their leader - that differentiates populism from grassroots politics. Last, the socio-cultural approach views populism as a performative style, 
which taps into "low" instead of "high" cultural expressions (Ostiguy, 2017). This approach investigates populism by looking at the praxis of politicians, rather than their ideas. The populist politician is "performing" the people, mostly in a loud and vulgar way.

The categorization of the approaches to populism into three mainstream ones is helpful. It provides an overview of the immense field that populism research recently has become. Taken together, the three approaches give a more or less complete picture of the phenomenon. However, as with many categorizations, it tends to overemphasize the differences between categories; many approaches fall under more than one mainstream category. For instance, Mudde (2017, p. 29) identifies Laclau's discourse approach to populism as ideational, based on the assumption that ideas and discourse are roughly the same. However, framing Laclau's approach as ideational underestimates his characterization of populism as a strategy: Laclau regards populism as the act of constructing the people as a signifier for dissimilar unsatisfied demands that are equalized as one accusation levelled at the group holding power (Laclau, 2005a, p. 85).

As an alternative, the multidimensional approach presented here offers a categorization that allows overlap. In this approach, populism occurs in three interrelated dimensions: the ideational, the social, and the presentational.

The three dimensions draw on Van Dijk's multidisciplinary ideological theory (I998, 20I3), explained in the next section. A semiotic analysis, summarized in the subsequent section, demonstrates how the three dimensions interact in populism. This analysis assesses populism in direct relation to the concepts of elitism and pluralism. The cohesion between the three concepts follows a strict logic.

- In the ideational dimension (the level of discourse structure), the logical opposition is between regarding the people as a heterogeneous group (pluralism) or not (populism and elitism). This mainly typifies the approach of Mudde (2017).

- In the presentational realm (the level of discourse use), the core opposition is between identifying with the people (populism) or not (elitism and pluralism). This mainly typifies Weyland's (20I7) and partly Laclau's (2005a) and Ostiguy's (20I7) approach.

- In the social realm, the core opposition is between power to the elite (elitism) or not (populism and pluralism). This partly typifies Ostiguy's (20I7) and Laclau's (2005a) approach. 
Most approaches to populism—also ones not mentioned-frame populism in one or two dimensions. The multidimensional approach presented here chooses to validate all three dimensions equally, since the concept is only internally consistent if three dimensions are combined. Additionally, it regards populism in direct relation to pluralism and elitism. This means that not only populism can be assessed; all political discourse can be characterized as a mix of populism, elitism, and pluralism-hence mainstream political styles as well. The approach is explained in the next three sections and applied in a speech analysis in sections thereafter. The last section contains more general conclusions and a discussion.

\section{Multidimensional Approach}

The following sections describe a multidimensional approach to populism that views the phenomenon as consisting of three intertwined dimensions. It partly draws on the discourse approach to ideology of Van Dijk (1998, 20I3). Van Dijk argues that ideology functions as a socially shared mental interface between group discourse and group action. The cognitive dimension of this framework cannot be reduced to the discourse or the social dimension of it; as grammar does not disappear the moment someone does not use a language, ideology, as a socio-cognitive framework, does not disappear when it is not expressed in discourse or social action. Hence, ideology comprises three levels: the cognitive, group, and discourse dimension (1998, pp. 53-58, 2013).

Van Dijk frequently uses an analogy with language and grammar to explain the relation between discourse and cognition (1998, Pp. 32, 53-58, 90, 148-50, 199). This shows that he transposes the Saussurean distinction between language use (parole) and language system (langue) to discourse (Saussure 1916/20I5). In this interpretation, the opposition between discourse and cognition can be understood as referring to discourse use and discourse system; both part of discourse, albeit at different levels of abstraction. In this chapter, I interpret the cognitive, group, and discourse dimension of Van Dijk as (I) the mental discourse structure, expressed in (2) the social world, and in (3) actual discourse use.

Van Dijk's approach to ideology is primarily functional: he focuses on the role ideologies play in society. Where Freeden's (1996) conceptual approach to ideology defines it as a constellation of concepts, Van Dijk defines ideology in its function of structuring group behavior and discourse. According to Van Dijk, ideology's functional structure is 
based on topics such as group membership, activities, goals, norms and values, group relations, and recourses (Van Dijk, 1998, pp. 69-70, 2013, p. 178). Different ideologies vary in their core functions (as they also vary in core concepts, in Freeden's definition); for instance, feminism is primarily a goal ideology, capitalism a resource ideology, and nativism a membership ideology. The topics describe the overall self-image of the group and its relations to other groups.

\begin{tabular}{|c|c|c|}
\hline & Ideologies & Populism \\
\hline Topics & Structured around questions such as: & Answers to those questions: \\
\hline Membership: & $\begin{array}{l}\text { Who are we? Who belongs to } \\
\text { us? Who is a member and who } \\
\text { can join? }\end{array}$ & $\begin{array}{l}\text { We are the people. The elite and others } \\
\text { are not. Who the people and the others } \\
\text { are differs per context. }\end{array}$ \\
\hline Activities: & $\begin{array}{l}\text { What do we (have to) do? What } \\
\text { is our role in society? }\end{array}$ & $\begin{array}{l}\text { We want change. What kind of change } \\
\text { differs per context. }\end{array}$ \\
\hline Goals: & What is the goal of our activities? & $\begin{array}{l}\text { We want change because others/the elite } \\
\text { are corrupt. Which action differs per } \\
\text { context. }\end{array}$ \\
\hline $\begin{array}{l}\text { Norms and } \\
\text { values: }\end{array}$ & $\begin{array}{l}\text { What are the norms of our } \\
\text { activities? What is good or bad } \\
\text { for us? }\end{array}$ & $\begin{array}{l}\text { The people are good. The others are not. } \\
\text { Main values and what should (not) be done } \\
\text { differs per context. }\end{array}$ \\
\hline $\begin{array}{l}\text { Group } \\
\text { relations: }\end{array}$ & $\begin{array}{l}\text { Who are our friends and who are } \\
\text { our enemies? }\end{array}$ & $\begin{array}{l}\text { The people are our friends; the others are } \\
\text { not. The people and the others differ per } \\
\text { context. }\end{array}$ \\
\hline Resources: & $\begin{array}{l}\text { What material or symbolic } \\
\text { resources form the basis of our } \\
\text { (lack of) power and our position } \\
\text { in society? }\end{array}$ & $\begin{array}{l}\text { We don't have power/we are the } \\
\text { underdog. The others have power/are the } \\
\text { elite or protected by them. Which } \\
\text { resources are required differs per context. }\end{array}$ \\
\hline
\end{tabular}

Table 5.I Van Dijk's $(1998,2013)$ cognitive-functional structure of ideologies applied to populism.

Table 5.I compares this functional structure of ideology with populism. The comparison shows that populism's core directly refers to this structure without further specifying it; populism mainly takes the functional structure of an ideology without adding content, as the latter differs per context. As already observed by many others, populism is conceptually too scrawny to be an ideology, not even a thin one (Aslanidis, 2016a; Freeden, 2017; Moffitt \& Tormey, 2014). Nevertheless, it discursively takes over the function of an ideology by labelling the in-group as the good people and the out-group as the corrupt elite. This 
interpretation neatly fits Freeden's characterization of populism as a "phantom ideology" (2017).

Populism having an ideological function entails that it encompasses Van Dijk's three ideological dimensions. To avoid the confusing opposition between cognition and discourse (as, in a post-structuralist interpretation, both are part of discourse) I named the three dimensions:

I The ideational dimension, referring to the mental discourse structure;

2 The social dimension, referring to the social praxis; and

3 The presentational dimension, referring to discourse use.

In the following section, a semiotic analysis of the concept of populism in relation to pluralism and elitism shows how the three dimensions interact in populism.

\section{Semiotic Analysis}

A semiotic analysis of populism in relation to other concepts reveals a logical structure tightly connecting populism to elitism and pluralism. This section provides an overview of these connections.

The ideational dimension is depicted in the lower triangle of Figure 5.I. In this realm, populism unites with elitism: although populism values the people as pure and elitism values them as ignorant or even bad, both concepts regard the people as one group. In this shared feature, the two concepts together are the opposite of pluralism, which views the people as multiple groups and individuals with conflicting interests. As separate concepts, populism and elitism only partly oppose pluralism; the two upper triangles in Figure 5.I show that they also share important features with pluralism. It is only in their commonalities that populism and elitism completely contradict pluralism. The anti-style of pluralism is, therefore, to be found in the common features of populism and elitism. This anti-style is defined as the negation of pluralism, hence as non-heterogeneous. This is broader than homogeneous; it can also be a united group that presents itself as one (see Chapter 4).

The social dimension is depicted in the upper left triangle of Figure 5.I. In this dimension, populism unites with pluralism: in both concepts, politicians are part of the people, regardless of whether the people are a heterogeneous group or not. This common 
feature is the direct opposite of elitism, where politicians are part of the elite. Whereas populism and pluralism both demand no power to the elite, in elitism, power naturally belongs to the elite. Hence, in the social realm, the shared features of populism and pluralism can be regarded as the anti-style of elitism. This anti-style is defined as the negation of elitism, hence as no power to the elite. This can mean power to the people or power to no one.

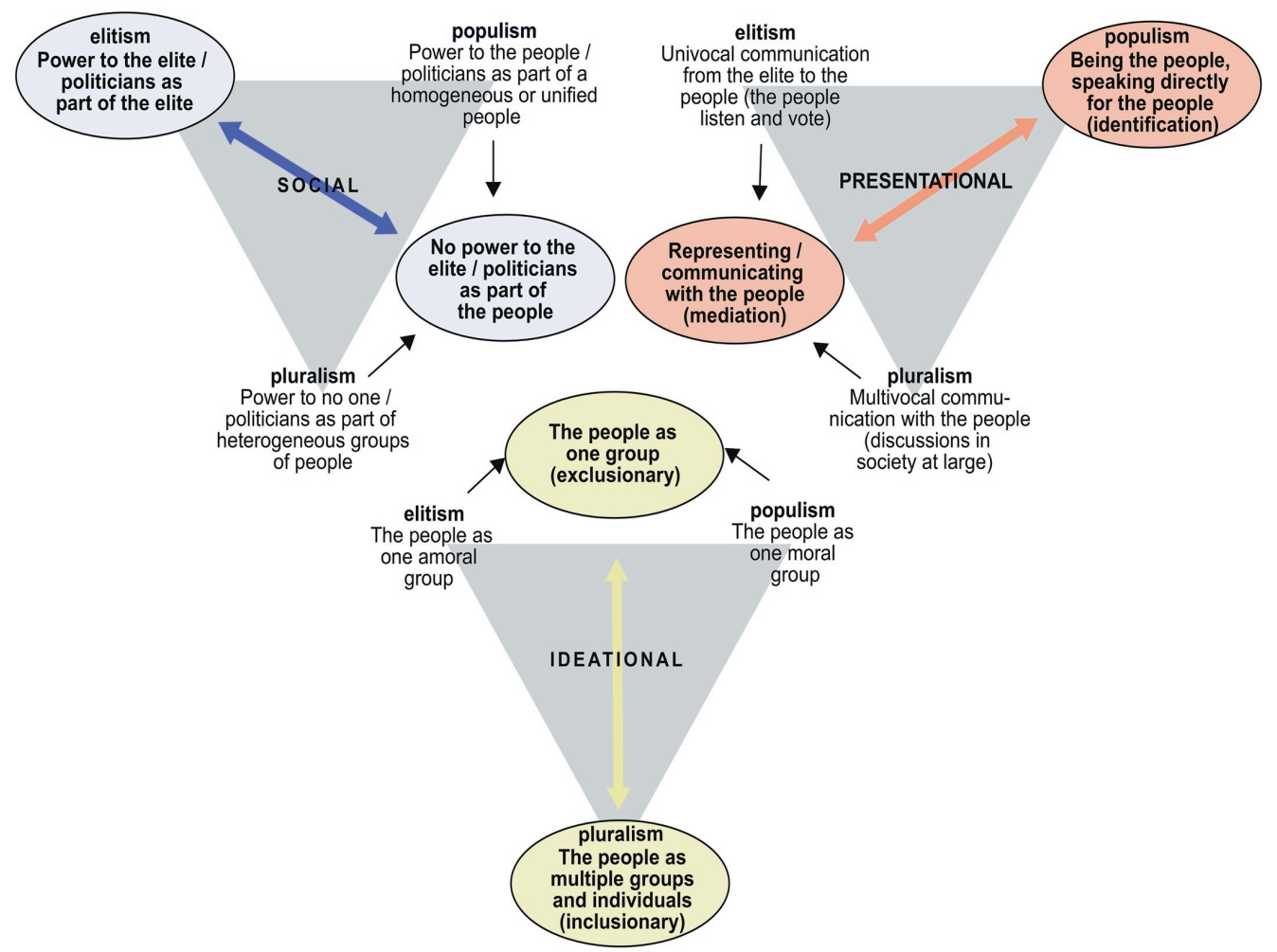

Figure 5.I The concepts of populism, elitism, and pluralism with shifting relationships in three dimensions.

The presentational dimension is depicted in the upper right triangle of Figure 5. I. Here, the shared features of elitism and pluralism are the anti-style of populism. Whereas the populist leader identifies with the people and claims to have an unmediated relationship with them, elitist and pluralist politicians have a mediated relationship with the people; they do not identify with the people, they represent them. In populism, leaders act as if mediation is not required because the populist and the people are one and the same. Obviously, in reality, populists abundantly communicate with the people, but in their communication, they speak 
directly for the people, being the voice of the people. This anti-style is defined as the negation of populism, hence as no identification with the people.

The three dimensions of Figure 5.I broadly match the categorization into three main approaches to populism, with which this chapter opened (Kaltwasser et al., 2017). The oppositions associated with the ideational dimension mainly match Mudde's (2004, 2017) view on populism; Mudde describes elitism as populism's mirror image, while populism and elitism together oppose pluralism. The oppositions in the presentational dimension mainly correspond to Weyland's (20I7) political-strategic approach; Weyland's "populist twist" refers to the identification of the populist with the people. Other approaches mix dimensions. For instance, on the one hand, Laclau (2005a) looks at the phenomenon through the social frame, as anti-elitism. On the other hand, he looks at populism using the presentational frame, seeing it as metaphorically equalising societal demands with the empty signifier of the people. Also Ostiguy's (2017) socio-cultural approach refers to the social dimension and to the presentational dimension. The question relevant to populism research is: how do these dimensions interact? The previous section already mentioned that the ideational realm can be regarded as the mental interface between the other two realms. Although it cannot be reduced to the other two realms, it can only be assessed through them. More concretely:

I. In the presentational realm (discourse use), all expressions contain ideas and acts; however, not all ideas or social practices are expressed.

2. In the social realm (social praxis), practices are based on ideas but not all ideas are acted on.

3. In the ideational realm (discourse system), ideas can exist without being expressed; however, they are only revealed through discourse use and social praxis. This closes the circle of the three realms and makes them indivisible as a study object.

The semiotic analysis confirms that the ideational realm is a separate level; a reduction of levels entails that populism contradicts itself, as in one dimension it fights together with elitism against pluralism and in the other dimensions it does the opposite. This would make populism an inherently contradictory concept, while it is perfectly logical at the three levels separately. Given their entanglement, the three dimensions in Figure 5.I can be combined 
into one framework that encompasses the three connected realms of the political styles, as described in Table 5.2.

\begin{tabular}{|c|c|c|c|}
\hline & Populism & Elitism & Pluralism \\
\hline Ideational & $\begin{array}{l}\text { The people as one } \\
\text { group } \\
\text { (non-heterogeneous) }\end{array}$ & $\begin{array}{l}\text { The people as one group } \\
\text { (non-heterogeneous) }\end{array}$ & $\begin{array}{l}\text { The people as } \\
\text { multiple groups } \\
\text { (heterogeneous) }\end{array}$ \\
\hline Social & $\begin{array}{l}\text { Politicians as part of the } \\
\text { people } \\
\text { (no power to the elite) }\end{array}$ & $\begin{array}{l}\text { Politicians as part of the } \\
\text { elite } \\
\text { (power to the elite) }\end{array}$ & $\begin{array}{l}\text { Politicians as part of the } \\
\text { people } \\
\text { (no power to the elite) }\end{array}$ \\
\hline Presentational & $\begin{array}{l}\text { Being the people } \\
\text { (identification) }\end{array}$ & $\begin{array}{l}\text { Representing the people } \\
\text { (no identification) }\end{array}$ & $\begin{array}{l}\text { Representing the people } \\
\text { (no identification) }\end{array}$ \\
\hline
\end{tabular}

Bold: unique feature | Regular: shared feature | Two features of one style always imply the third, in every order.

Table 5.2 Main features of populism, elitism, and pluralism in one framework.

One style always combines two non-unique features in a unique way. Therefore, it is not the specific features that make the style unique; it is the specific combination of features, as follows:

- Populism regards the people as one body and their leader as part of that body. This implies that this leader has unmediated knowledge of the people because the group is seen as one, which entails that the leader is identical to the people. This does not have to be a nativist homogeneous people; it means homogenized enough to present the members of this group as being essentially the same.

- Elitism regards the people as one more or less homogeneous group, while their leader has a mediated relationship with the people. This implies that elitist politicians are not part of the people, because if they were, they would have had unmediated knowledge of the people, since in a homogeneous group all people are essentially the same.

- In pluralism, leaders are part of the people but do not claim to have unmediated knowledge of the people. This implies that the people are not all the same; they are an assemblage of multiple groups and individuals.

The connection between populism, elitism, and pluralism can be depicted in a triangular framework, as in Figure 5.2. The unique (bold) features of Table 5.2 are transposed to the 
corners of the triangle: they represent the pure styles: elitism, populism, and pluralism. The shared features of Table 5.2 are transposed to the sides of the triangle: they represent the mixed styles. The triangular framework also displays the oppositions between the shared features (the sides) and unique features (the corners): these are depicted in the arrows in the middle of the triangle. The arrows depict the dimensions in which these oppositions occur.

The ideational dimension (cognition, discourse structure):

Main opposition: in-out ${ }^{12}$, between everybody belonging to the people (pluralism) or not everybody belonging to the people (populism and elitism).

Framings: thinking of the people as inevitably divided versus thinking of the people as an imaginary whole.

The social dimension (social praxis and group relations):

Main opposition: up-down, between politicians as part of the people and demanding power to the people (populism and pluralism) versus politicians as part of the elite, restricting power to the elite (elitism).

Framings: thinking of the elite as an opponent of the people (a villain) versus as the helper of the people (a hero).

The presentational dimension (communication, discourse use):

Main opposition: next to-on top of, between standing next to people, representing them (elitism and pluralism) or identifying with/taking the place of the people (populism).

Framings: thinking of politicians as remote from the people versus thinking of a (populist) politician as metaphorically being the people.

12 The spatial oppositions connected with the dimensions "in-out", "up-down" draw on De Cleen (2017) and Stavrakakis and De Cleen (2017) who characterize populism as discourse structured on an "updown" opposition, and nationalism as discourse structured on an "in-out" opposition. The connection with the three dimensions shows that their approach frames populism in the social dimension. It goes beyond the scope of this chapter to discuss this further, see also the last section. 


\section{A Method for Speech Analysis}

The framework explained in section 3 is applied to a speech analysis method that captures political styles in elitist, populist, and pluralist features. The basis of the analysis method is described in Chapters 2 and 3, where political style is defined as "the performance of politicians on the political front stage before an audience”. This definition of political style draws on the multidisciplinary ideological approach of Van Dijk (1998) and on style theories from diverse disciplines (Ankersmit, 1996; Coupland, 2007; Giddens, 199I; Pels, 2003a), more elaborately discussed in Chapters 2 and 3 . Although the method is primarily centered on the discourse of political leaders, it is broadly applicable to political discourse, because political institutions can be regarded as (abstract) political personas, communicating with their potential voters and other political players in a specific voice.

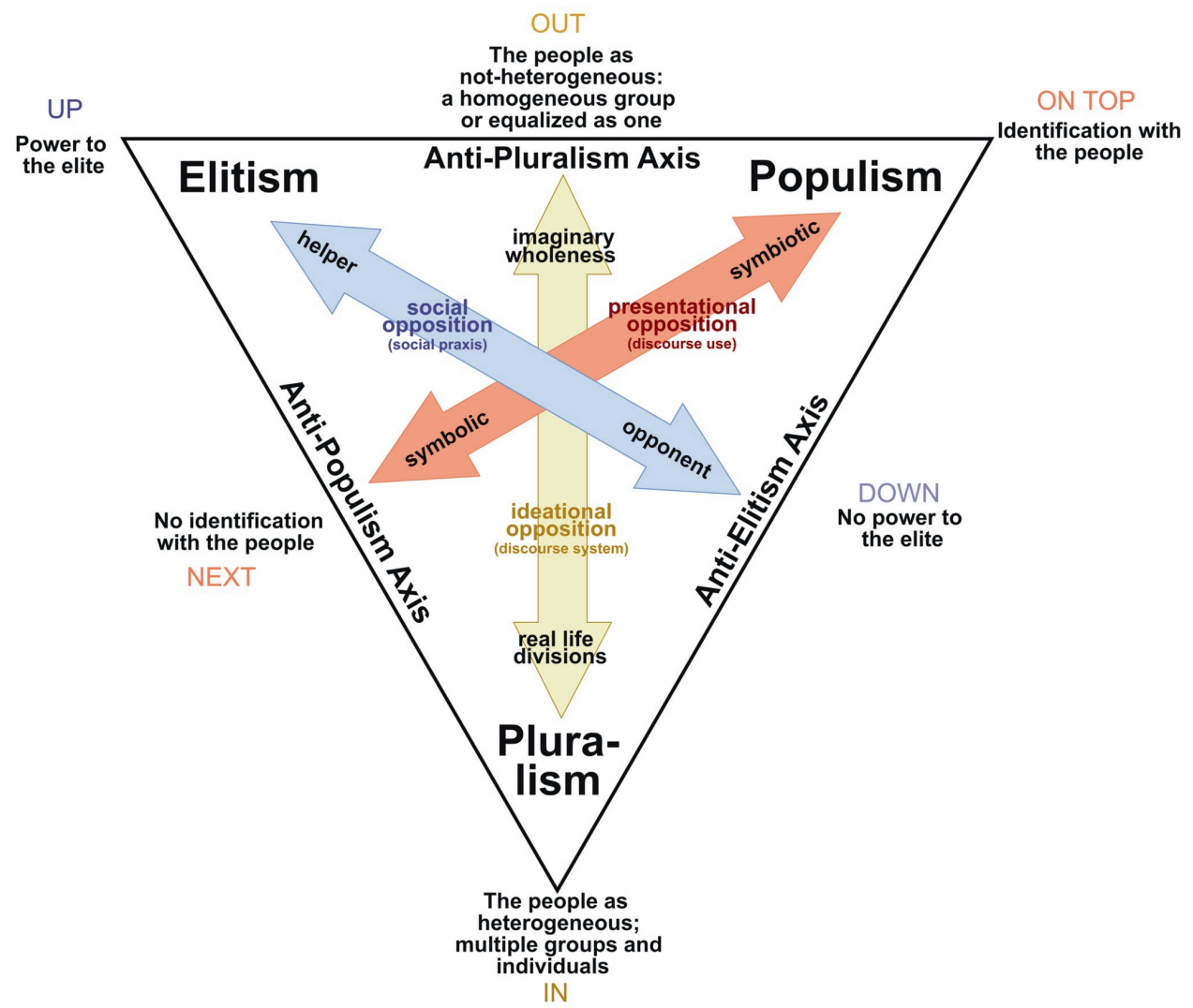

Figure 5.2 The triangular relationship between populism, elitism, and pluralism. 
The three dimensions of political style are tightly interwoven. However, they can be assessed more or less separately when analyzing political discourse. This kind of discourse analysis is complex; it involves all levels of text and context as well as the broader social context. To ensure a systematic analysis, in Chapter 3, I deconstructed political style as consisting of five discursive elements related to the political stage, building on Wodak's (2015) and Goffman's (1956) analyses of the presentation of the (political) self. The elements refer to the aspects of the political stage in which political performances can differ from each other discursively, namely: (I) The people, (2) The elite, (3) Democracy/government, (4) Politics, and (5) The political context (see Chapters 2 and 3). The context-derived labels populism, elitism, and pluralism logically match all five elements and are chosen for this reason. Relating the five elements to the populism literature shows that they all figure in the different approaches, but not one approach contains all five. As this method does not follow one populism theory but combines all, this is not a problem; to the contrary, analyzing the elements separately might in the long run clarify the role of alleged core and peripheral features in populism.

For speech analysis, the descriptions of the three main oppositions that distinguish populism from elitism and pluralism (see Table 5.2 and Figure 5.2) need specifications. Grouped around the five elements of the political stage, more detailed features are defined, based on additional semiotic analyses and on the existing literature on populism (Kaltwasser et al., 2017; Mudde, 2017; Ostiguy, 20I7; Weyland, 2017), elitism (Mackie, 2009; Schumpeter, 2008), and pluralism (Blokland, 20II). The fifteen sub-features are described in Figure 5.3 and in appendix D. The framework captures populism as a relative matter: nothing is populist in itself; something is populist only in relation to the other styles and antistyles, implying that discourse can be more or less populist. It forms the core of a digital analysis instrument, the PEP-index 2.0, an acronym of the initials of Populism, Elitism, and Pluralism.

The instrument is an adaption of an analysis method described in Chapter 3. The main difference between the two versions is the application of the logic described in the previous section, transforming the linear into a triangular scale because the three dimensions of political style are even more entangled than earlier acknowledged. The advantage of the new triangular logic is that it precisely defines what populism is and 


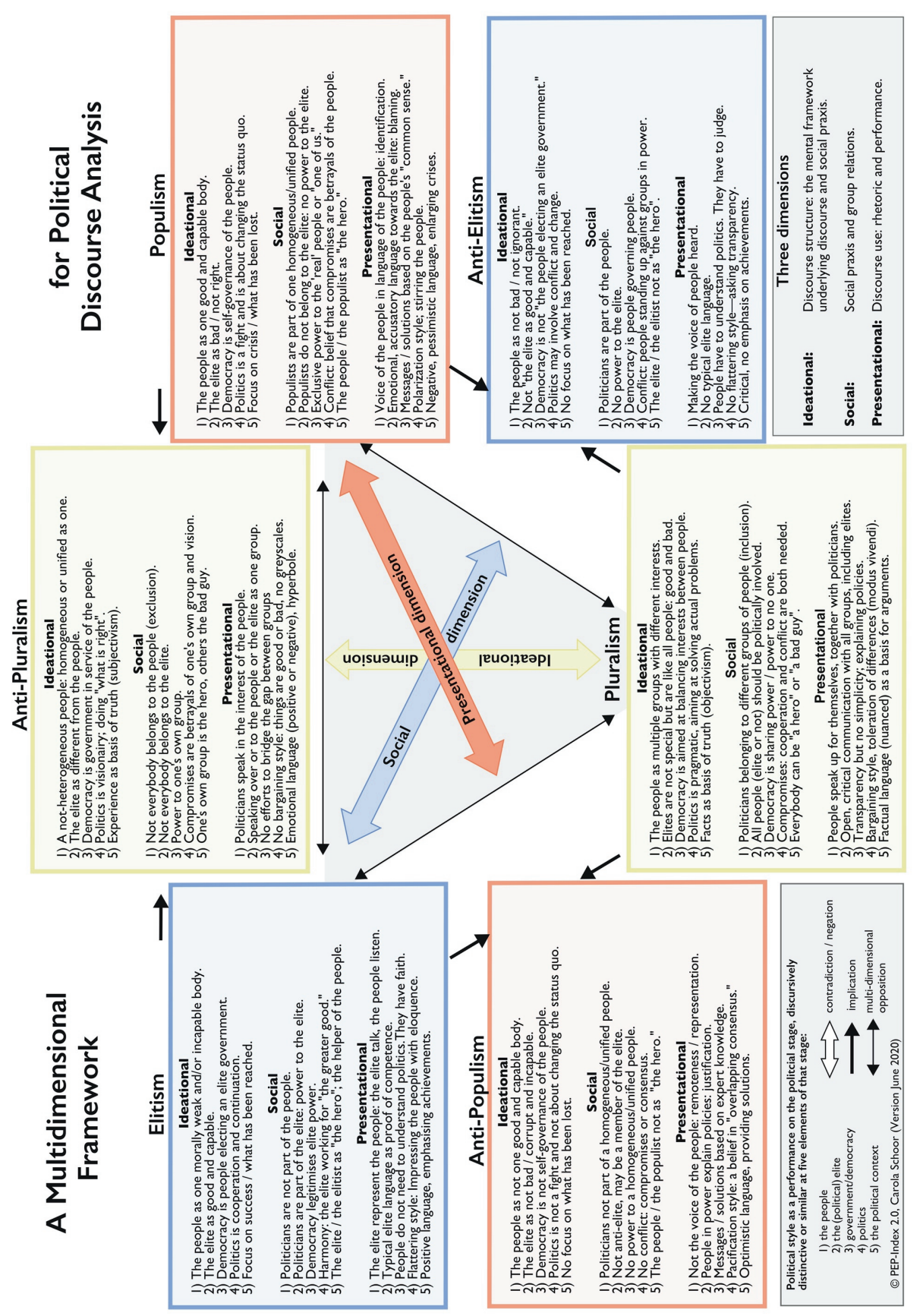

Figure 5.3 Political styles and anti-styles in five elements and three dimensions. 
what populism is not (namely: the shared features of elitism and pluralism). This makes it possible to build an unambiguous analysis instrument to assess whether speech fragments are populist, elitist, pluralist, or not. With the features of figure 5.3, speeches of all politicians-populist or not—can be analyzed on the political style of the fifteen described sub-elements.

\section{The Analysis}

In the following sections, political performances of nine politicians in three countries (the US, the UK, and the Netherlands) are analyzed and compared. Besides political speeches, contributions to (broadcast) political debates are analyzed. The analyzed performances are listed in Appendix A. Quotations in the following sections refer to the numbers in Appendix A. Politicians were chosen that are all regarded as populist to some extent; some are uncontestably seen as populist, others' populism is contested. As the analysis model assesses all political styles, the analysis can shed light on these contestations.

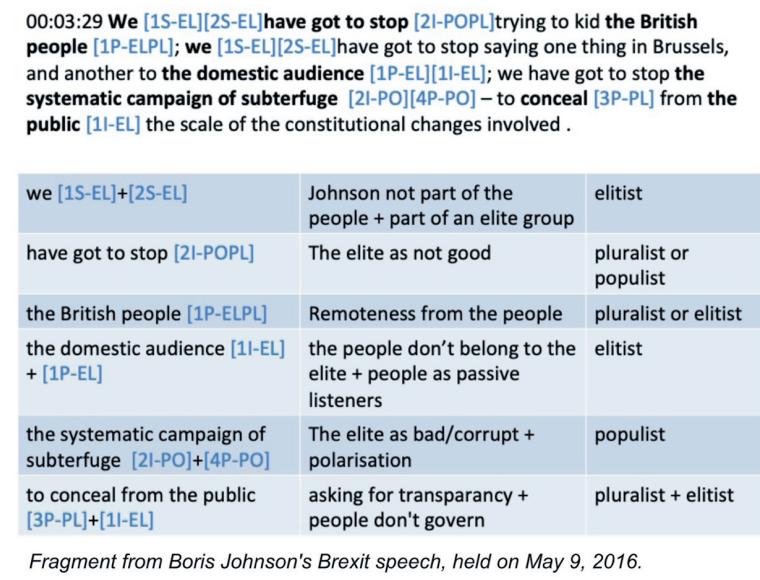
people [1P-ELPL]; we [1S-EL][2S-EL] have got to stop saying one thing in Brussels, and another to the domestic audience [1P-EL][1I-EL]; we have got to stop the systematic campaign of subterfuge $[2 \mathrm{I}-\mathrm{PO}][4 \mathrm{P}-\mathrm{PO}]-$ to conceal $[3 \mathrm{P}-\mathrm{PL}]$ from the public [1I-EL] the scale of the constitutional changes involved .

\begin{tabular}{|c|c|c|}
\hline we $[1 S-E L]+[2 S-E L]$ & $\begin{array}{l}\text { Johnson not part of the } \\
\text { people }+ \text { part of an elite group }\end{array}$ & elitist \\
\hline have got to stop [2I-POPL] & The elite as not good & $\begin{array}{l}\text { pluralist or } \\
\text { populist }\end{array}$ \\
\hline the British people [1P-ELPL] & Remoteness from the people & pluralist or elitist \\
\hline $\begin{array}{l}\text { the domestic audience [1l-EL] } \\
+[1 \mathrm{P}-\mathrm{EL}]\end{array}$ & $\begin{array}{l}\text { the people don't belong to the } \\
\text { elite + people as passive } \\
\text { listeners }\end{array}$ & elitist \\
\hline $\begin{array}{l}\text { the systematic campaign of } \\
\text { subterfuge }[21-\mathrm{PO}]+[4 \mathrm{P}-\mathrm{PO}]\end{array}$ & $\begin{array}{l}\text { The elite as bad/corrupt + } \\
\text { polarisation }\end{array}$ & populist \\
\hline $\begin{array}{l}\text { to conceal from the public } \\
{[3 P-P L]+[1 \mid-E L]}\end{array}$ & $\begin{array}{l}\text { asking for transparancy + } \\
\text { people don't govern }\end{array}$ & pluralist + elitist \\
\hline
\end{tabular}

Figure 5.4 A fragment of a coded speech of Boris Johnson in 2016.

Figure 5.4 gives an example of how speeches are coded with the help of the model depicted in Figure 5.3. It displays a fragment of the 2016 Brexit speech of Boris Johnson (no 9). The example illustrates that the same sentence can contain different styles. For instance, in the displayed fragment Johnson speaks as part of the elite and not of the people. This is elitist at 
the social dimension of the people [IS-EL] and the elite [2S-EL]. At the same time, he critici-zes the elite, which is populist or pluralist at the ideational dimension of the elite [2I-POPL]. The codes are listed and explained in Figure 5.4 and refer to the features in Figure 5.3.

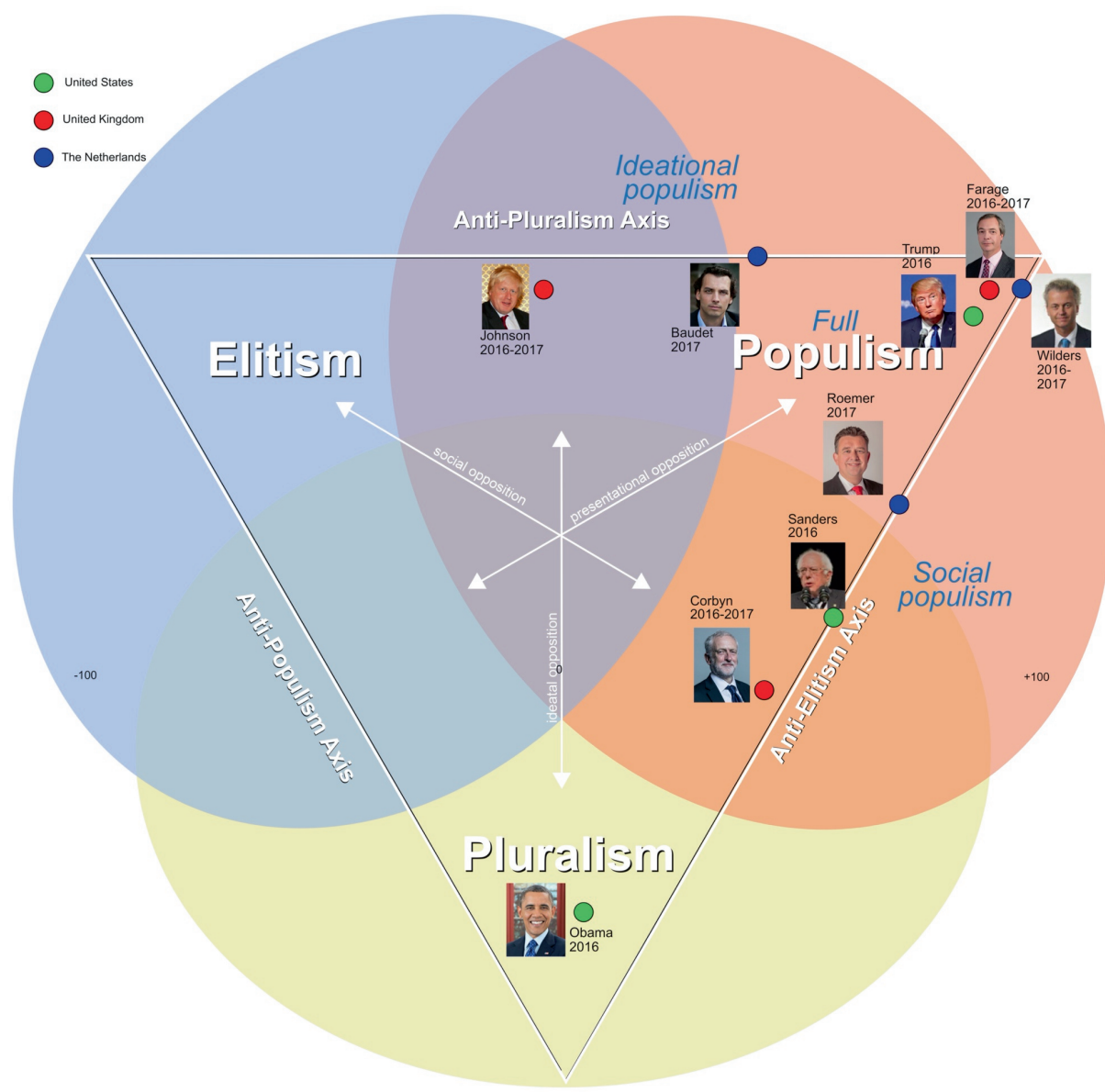

Figure 5.5 The political styles of nine politicians plotted on a triangular field, capturing them as a mix of populism, elitism, and pluralism. The sub-scores are provided in Appendix B

After coding the speech, the PEP-index (using FilemakerPro software) assembles all coded fragments for each sub-element to allow the analyst to assess the overall style of this subelement. An advantage of assessing the fifteen sub-styles individually is that the average 
score is thoroughly considered; all fragments are analyzed twice at the least ${ }^{13}$. Also, the separate sub-scores provide insight into the rationale behind the scores. The overall scores of the analyses are plotted on a triangular framework in Figure 5.5, visualizing the relationship between populism, elitism, and pluralism. The full analyses are too widespread to display; the following sections will discuss fragments that illustrate the overall score. The sub-scores of the style analyses are displayed in Appendix B.

\section{Who is the Real US Populist?}

The 2016 US primary elections were selected for this analysis because two of their participants, Donald Trump (Republican) and Bernie Sanders (Democrat), are generally regarded as populists (Kazin, 2016). Additionally, Barack Obama (Democrat) is included. Although he is mostly not regarded as a populist, he was chosen because he claimed to be the "real" populist instead of Trump:

Now I suppose that makes me a populist. Somebody else, who has never shown any regard for workers, has never fought on behalf of social justice issues, or making sure poor kids get a decent shot in life, or have healthcare; in fact, has worked against economic opportunities for workers and ordinary people. They don't sound like becoming a populist because they just say something controversial in order to win votes. That's not a measure of populism (2, 01 : 10:44).

The analysis will show in which dimension this claim is grounded and where the political styles of Obama, Trump, and Sanders meet. Speeches of these three politicians (listed in Appendix A) were analyzed and compared. ${ }^{14}$ The results of the speech analyses are depicted in Figure 5.5 and the separate sub-scores in Appendix B. Figure 5.5 shows that the three styles are all positioned close to the anti-elitist side of the triangular framework. This means

13 Ideally, this should be done by different analysts to cross-check the analysis. For practical reasons this is not always possible, in which case it is important to make the coding transparent by briefly justifying the codes. The latter method is followed in the here-performed analysis.

14 Trump's and Sanders's speech analyses are more elaborately described in Chapter 3. These descriptions use an earlier version of the method and differ in detail. 
that they can all be regarded as anti-elitist. However, they also differ: Trump is populist, Obama is pluralist, and Sanders is mixed populist-pluralist.

\section{I Obama’s political style.}

In the analyzed speech (Speech I), Obama speaks mostly of the people as an assemblage of different groups and individuals. The people are united but are not one homogeneous group, which is ideationally pluralist:

I see Americans of every party, every background, every faith who believe that we are stronger together-black, white, Latino, Asian, Native American; young, old; gay, straight; men, women, folks with disabilities [II-PL], all pledging allegiance, under the same proud flag, to this big, bold country that we [IS-POPL] love (Speech I, I2:03).

Speaking of the people as "we" reveals that Obama sees himself as part of the people, which is socially populist or pluralist:

We're not a fragile people. We're not a frightful people [IS-POPL]. Our power doesn't come from some self-declared savior promising that he alone can restore order as long as we do things his way. We don't look to be ruled [IS-PO][IPPO][II-PL] (Speech I, 25:35).

In the phrase "We don't look to be ruled," Obama and the people are one against an authoritarian ruler (Trump). Obama speaks directly for the people here, instantly knowing that the people do not want to be ruled; this is presentationally populist. Also, it implies that Obama and the people are currently ruling themselves, when in fact Obama rules the people. This is an evident example of the populist twist, in which the leader and the people are depicted as identical, which is also populist in the presentational realm. However, this twist only occurs when Obama defends his (threatened) pluralist values against Trump because in populism, an authoritarian ruler is accepted if they are one of us, but in pluralism, authoritarianism is never right. Hence, this trait is pluralist at the ideational level. Additionally, Obama expresses elitist elements, speaking of the political elite (Clinton) as good and of the political context (his own policies) as being in progress. In both he 
combines elitism with pluralism because he also advocates change and says that politicians should do better. The sub-scores in Appendix B show that, overall, the pluralist label fits Obama best.

\subsection{Trump’s political style.}

Trump's analyzed speeches (no 7 and 8 ) show that he has a full populist style in all dimensions. For Trump, the people are ideationally one, he is socially one of us, and speaks directly for us in the presentational realm. All three features are visible in this quote:

You see it really in the whole fabric of the community and what are New York values? Honesty and straight-talking. [II-PO] A lot of times people say, oh, you tell it too straight mister Trump. I think that is what we like [IS-PO]. That you think? You see it in our work ethic. We work hard and we are proud. You see it in our family values (...) We are builders. We make things [IP-PO] (Speech 7, 20:30).

Abundantly, Trump uses the populist twist; speaking directly for the people as if he is the people. He regularly shouts, together with his audience, "Build that wall, build that wall, build that wall" and then replies to the public and himself that he is going to build it. This speaking as one voice belongs to the presentational dimension of populism.

\subsection{Sanders' political style.}

Sanders's analyzed speeches (no 3 and 4) show a pluralist ideational style regarding the people, close to Obama's. Both view the people as consisting of multiple groups:

What this campaign is about, is the understanding that when we stand together, black, and white, and Latino and Asian American, and Native American. When we do not allow the Donald Trumps of the world to divide us up, there is nothing we cannot accomplish [II-PL] (Speech 3, I:I7:00).

However, Sanders's style meets Trump's in his populist definition of the elite as one corrupt group. This makes his ideational political style mixed populist-pluralist. Socially, Sanders is 
part of the people, which is also mixed populist-pluralist. Presentationally, Sanders communicates with the people, which is pluralist. However, he also often performs the populist twist, speaking directly for the people, which is populist. He even plays with that, letting the people end his sentences:

What people say, they say "Hey Bernie, you're thinking too biiiig” (accent). Your ideas are just, just...[crowd yelling "Huuuuge”] (Sanders laughing). Yes, your ideas are too Huuuuuuge... I don't think so [IP-PO] (Speech 3, I:57:30).

\subsection{Obama, Trump, and Sanders compared.}

In Figure 5.5, the dimensions of populist styles can be derived from their position in the triangular framework. At the level of sub-scores, the three dimensions are too entangled to get a clear view, However, because populism's meaning differs in each dimension, it can be discerned looking at the overall score. A position near the anti-elite side means that populism is socially enacted, whereas a position near the anti-pluralist side tells us that populism is ideationally imagined. A position in the populist corner means that it is, besides the above, also presented in a populist way.

Hence, while Sanders, Trump, and Obama are all populist if solely looked at within a social frame (i.e., anti-elitist), only Trump is a populist in all three dimensions (social, ideational, and presentational). Sanders is populist in a social frame and mixed populistpluralist in the presentational and ideational dimension. Obama is only populist in a social frame and, partly, in the presentational realm.

\section{Three kinds of populism in the UK}

The Brexit campaign is relevant to an investigation into populist styles because it is broadly recognized that populism played a role in the voting to leave the EU (e.g., Freeden, 2017; Norris \& Inglehart, 2019). This section assesses the amount of populism present in speeches held during and after the UK Brexit campaign in 2016 and 2017: of Nigel Farage (UKIP), Boris Johnson (Conservative Party), and Jeremy Corbyn (Socialist Party). Whereas the first two politicians campaigned to leave the EU, the latter canvassed to remain. However, all 
three are said to have used populist strategies; most obviously the Brexiteers but also Corbyn is discussed as having a populist style (Mouffe, 2018a).

The political styles of UK politicians analyzed here are each based on a Brexit speech for a broad audience held in 2016 (no 12, 15, and 18), and a post-Brexit speech held in 2017 for party members or similar groups (no 13, 16, and 19). The results of the analyses are depicted in Figure 5.5 and the sub-scores in Appendix B. The styles of the speeches during and after the Brexit campaign differed from each other but the general position in the triangular framework stays within the same range: Johnson's style can be characterized as mixed populist-elitist, Corbyn's style as mixed populist-pluralist, and Farage's style as fully populist. ${ }^{15}$

\section{I Farage’s political style.}

Farage's populist style is expressed in the combination of seeing the people as one homogeneous group - the pure people who know what is right - and Farage being part of that group, instantly knowing what is right and what the people feel and want, as visible in this quote:

We have given away our basic rights, our basic freedoms, our basic concept of parliamentary democracy [IS-PO][IP-PO][3I-PO]. All of that has been sold and given away on a lie that unless we're part of this club that they won't do business with us [2I-PO][3I-PO]. Not only we will do business with that club, but we will also remember, once we've left, who we are as a people [II-PO], and who our friends are around the world (Speech 12, 00:09:14).

Farage is clearly anti-elite, as he mocks others for their elite background. He himself is part of the common people-which is populist or pluralist-displaying his common background: working as a trader and with a common mother who is proud that her son appears at a famous stage, as in: "My mum's really proud l've appeared at the Palladium you know" [ISPOPL] (Speech 12, 00:02:30). And in:

15 The differences between the 2016 and 2017 speeches are part of an ongoing investigation into style developments of British politicians from 2015 onwards, which will be reported on in a separate article. 
And unlike Clegg and Blair and Cameron and Mandelson and all of them, unlike all of them, who've come straight from university into research into politics and never done a proper day's work in their lives. Unlike them, unlike them, I've spent twenty years working in global trading business [2S-PO][2I-PO][IS-POPL] (Speech I2, 00:06:50).

In the end, his membership of the people is assessed as populist and not pluralist because he excludes others from belonging to the people, as in this quote:

So the point is that open-door immigration, even to those who are not really particularly interested in politics, or self-government, or sovereignty, every one of us [IS-PO] can see how fundamentally society has changed over the course of the last twelve years (Speech 12, 00:20:30).

\subsection{Johnson's political style.}

Johnson's speeches (no 15 and 16) display him as an obvious part of the elite, flaunting his aristocratic background in response to accusations that he was a liberal cosmopolitan and "had no right to vote leave":

I am a child of Europe. I am, as I say, a liberal cosmopolitan. My family is genetically equivalent to a UN peacekeeping force. I can read novels in French, I can even read a novel in Spanish, I can sing the Ode to Joy in German [someone shouts: do it then]. I will, and if they keep accusing me of being a Little Englander, I will. [Starts singing] “Freude, schöne Götterfunken” [2S-EL][2P-EL] (Speech I5, 00:34:27).

In both speeches analyzed, Johnson refers to the people as "they"; a homogeneous group that he is not a part of. In the speech to the Conservative Party, he even speaks of the people as an animal (a lion, the symbol of England) and himself as the lion tamer, which can be regarded as exceptionally elitist:

We are not the lion. We do not claim, like some others, to be the lion. That role is played by the people of this country. But it is up to us now-in the traditional non- 


\section{CHAPTER 5}

threatening, and genial, self-deprecating way of the British-to let that lion roar [ISEL][2S-EL] (Speech 16, 28:0I).

Besides, Johnson uses many populist elements, such as attacking the European elite, viewing democracy as unfair, polarizing, and regarding the political context as being in crisis:

The independence of this country is being seriously compromised. It is this fundamental democratic problem - this erosion of democracy-that brings me into this fight [3I-PO][4I-PO][4P-PO] (Speech I5, 00:04:37).

We were told that we would be able to stop the Eurozone countries from using the EU institutions to create a fiscal and political union. We got nothing; instead, we gave up our veto [2I-PO] (Speech 15, 00:1 I:13).

His Brexit speech contains more populist elements than his post-Brexit speech, suggesting that populism is used as a political-strategic instrument to mobilize the people. This is populist in the presentational realm. However, even though Johnson often uses populist, polarizing language, he never says that he and the people are one. He speaks of "we Britain," referring to the people and the elite together forming a coalition against the other, European elite. In this sense, Johnson is mixed populist-elitist or anti-pluralist. ${ }^{16}$

\subsection{Corbyn's political style.}

Johnson's and Farage's anti-pluralism is directly opposed to Corbyn's style (Speeches 18 and 19). He sees the people as different groups and individuals:

And Labour was the party of unity, bringing generations and communities together, rather than pitting young and old against each other, as the Tories [II-PL] (Speech 19, 17:20). 
In this quote, Corbyn recognizes the differences between generations and communities, signifying that they are not one by nature but need to be united. This entails that Corbyn does not regard the people as a homogeneous group; he is pluralist in the ideational dimension of element (I), the people. The following quote shows that he sees himself as part of the people, which is populist or pluralist in the social dimension of element (I) The people:

My principles come from my mum and dad and the way they brought me up and the principles they gave me. They come from my family, they come from the community I live in and I am very proud to represent in Finsbury Park. They are my roots and they ground everything I do [IS-POPL] (Speech 19, 2017, 13:10).

Corbyn is not only part of the people but also accusatory towards the elite, associating them with oligarchs. This is populist in the social dimension of Element I the people, and at the ideational dimension of element (2) The elite:

Left to themselves, it is clear what the main Vote Leave vision is for Britain: to be the safe haven of choice for the ill-gotten gains of every dodgy oligarch, dictator or rogue corporation [2I-PO] [IS-PO] (Speech 18, 12:37).

Corbyn's style during the Brexit campaign is, other than Johnson's, slightly less populist than afterwards. This is mostly due to the difference between defending the status quo and the political elite during the Remain campaign and attacking the government and proclaiming a crisis in 2017. Overall, Corbyn's style is socially populist and presentationally and ideationally mixed populist-pluralist. His style comes close to Sanders's style but is slightly less populist, mostly as a result of his defense of the status quo during the Remain campaign. His post-Brexit speech has almost the same overall score as Sanders's.

\subsection{Farage, Johnson, and Corbyn compared.}

While Johnson, Corbyn, and Farage are all populist in their own way, they are so in different dimensions. As visualized in Figure 5.5, Johnson combines populism with elitism. He is mainly anti-pluralist. This is populist in the ideational dimension. Corbyn, on the other hand, 
combines populism with pluralism. He is mainly anti-elitist. This is populism in the social dimension. Farage combines both variants of populism. He is both anti-pluralist and antielitist. This makes him fully populist in three dimensions. Apart from being socially and ideationally a populist, Farage is also fully populist in the presentational dimension, in which he speaks as if he is the people. In this dimension, Corbyn and Johnson are only partly populist-using populist language without directly speaking for the people.

\section{Three Full Populists in The Netherlands}

In the Netherlands, there is a long tradition of two kinds of populism: right-wing populism of the Freedom Party (PVV) and left-wing populism of the Socialist Party (SP) (Lucardie, 2008). Recently, a second right-wing populist party has entered the political stage: Forum for Democracy (FvD). Speeches of the three populist leaders during the 2017 elections (Geert Wilders-PVV, Emile Roemer-SP, and Thierry Baudet-FvD) are analyzed to compare their populisms (no 20 to 26). The three political styles, depicted in Figure 5.5 and in Appendix B, all score within the full populist range of the triangle of Figure 5.5. Still, there are differences.

\section{I Wilders' political style.}

Wilders scores as being most populist of the three. He combines his perception of the people as one homogeneous group (ideational populism) with his membership and allegiance to that group (social populism) into a full populist style, including being the people's voice (presentational populism):

My friends, this year will be the year of the people! The year in which the voice of the people is finally heard ${ }^{17}$ [IS-PO][IP-PO][II-PO] (Speech 2I, 20:10). The people don't believe this government. (...) The people don't believe that this gov-ernment wants the best for Netherlands ${ }^{18}$ [II-PO][IP-PO][2P-PO][2S-PO]( Speech 20, 40:20).

17 Original in German: "Meine Freunde, dieses Jahr wird das Jahr des Volkes sein! Das Jahr, wo die Stimme des Volkes endlich gehört wird!"

18 Dutch: "Nederland trapt daar niet in. ... De mensen geloven niet dat het kabinet het goede met Nederland voor heeft." 


\subsection{Baudet's political style.}

The second politician analyzed, Baudet, portrays himself as a conservative and nationalist, bringing back old values and being proud of Dutch history and culture. He often agrees with Wilders's standpoints, but deems him too aggressive and uncooperative. Although Baudet's style is clearly populist and very much against the current political elite, the speech analysis shows that he does not endorse anti-elitism: Baudet is even building "a new elite," which means that he is only opposed to the current group holding power, which he calls "the party cartel":

We are going to train a new elite; we are going to replace and defeat the current leaders $^{19}$ [3I-EL][2I-PO][5S-PO]( Speech 24, I0:38).

The speech analysis locates him at the anti-pluralism side. Baudet combines fully ideational populism (seeing the people as one good, homogeneous group) with partially social populism (being a member of the people and the elite) and a fully populist presentation style (the populist twist of being the people and of speaking on behalf of the people). The latter is visible in this quote, in which the "us" refers to Baudet and the people together as one against the political elite:

Politicians don't trust us anymore. Politicians have the idea that the moment that we get a say in anything, we would take the most idiotic decisions ${ }^{20}$ [2I-PO][3I-PO] (Speech 25, 11.40 ).

\subsection{Roemers' political style.}

The style of the third Dutch politician analyzed, the socialist Roemer, is positioned at the anti-elitist side of the triangular framework of Figure 5.5. Socially, Roemer is a populist, denouncing the elite as wrong. Ideationally, Roemer is a pluralist, in his definition of the

19 Dutch: "We gaan een nieuwe elite opleiden; we gaan de huidige leiders vervangen en verslaan."

20 Dutch: "De politiek vertrouwt ons niet meer. De politiek heeft het idee dat zodra we ook maar iets te zeggen krijgen, de meest idiote beslissingen zouden nemen." 
people: he sees the people as consisting of multiple groups and individuals. He is, nevertheless, populist in his definition of the elite as corrupt. Presentationally, he speaks in the language of the people about what the people think and feel, which is populist or pluralist. However, he does not say that all people want the same; only that most people do, which is mixed populist-pluralist. Hence, he expresses the voice of the people but does not become the people entirely:

But we also stood by the people working in healthcare, who were continually hit. At those moments, I stand beside them, for them, and with them, in parliament to make sure that the voice of the street is heard here too. ${ }^{21}$ [IP-PL][IS-PL][3S-PL] (Speech $23,00: 46: 00)$

\subsection{Wilders, Baudet, and Roemers compared.}

The three Dutch populist politicians all have a fully populist style. Nevertheless, this gives room to express three different political sounds. Wilders is fully populist in all three dimensions. Baudet is fully populist in the ideational and presentational dimension; in the social dimension he is mixed populist-elitist. Roemer is fully populist in the social dimension; in the presentational and ideational realm, he is mixed populist-pluralist.

The next section will discuss the differences and similarities between the nine analyzed political styles from a larger distance and consider suggestions for populism theory in general.

\section{Discussion and Conclusion}

The triangular framework presented here captures political styles in a logical field that offers an unambiguous choice between what populism is and what it is not: non-populism is specifically defined as the shared features of elitism and pluralism. An advantage of this approach is that populist and non-populist political styles can be assessed as gradations of

Original Dutch: "Maar we stonden ook aan de zijde van die mensen in de zorg die continu gepakt werden. Want dan sta ik naast hen, voor hen en met hen, in de Kamer om te zorgen dat het geluid van de straat hier te horen is." 
populism, pluralism, and elitism. In this way, all political discourse-mainstream or populist - can be compared. Another advantage is that speeches from different contexts can be related to each other at a more abstract level. Moreover, it brings different approaches of populism together, opening doors to a broader understanding of populism.

The distinct sub-scores of the three dimensions (see Appendix B) come close to the overall score, indicating that the three dimensions are, indeed, too entangled to separate ${ }^{22}$. This was to be expected, as they can only be known through each other. Because the meaning of populism is different in the three dimensions, the overall score reveals which dimension is dominant in the construction of this particular discourse: a position near one side of the triangular scale tells us which dimension a style reflects: ideational, social, or presentational. A position near a corner means a combination of dimensions.

The distinct sub-scores of the five elements (see Appendix B) show a larger deviation than the three dimensions, but not in a specific pattern. An explanation is that every political style consists of a unique combination of style elements that are influenced by personal and contextual factors, such as the background of a politician, the audience, or a referendum that is taking place.

The analysis in this chapter suggests one emerging pattern particularly worthy of investigating further: in the US, the UK, and the Netherlands, left-centered populists (Sanders, Corbyn, and Roemers) are all situated at the populist-pluralist (anti-elitist) side. This suggests that they mainly express populism in the social dimension: being part of the people and claiming power for the people. Additionally, right-centered populists (Johnson, Baudet) are situated at the elitist-populist (anti-pluralist) side. This means that they mainly express populism as an idea; that the people are a moral homogeneous group. Populists that combine left and right features (Trump, Farage, and Wilders) are close to the populist corner, combining the two axes. This means that they express populism in all three dimensions: ideational, social, and presentational. Complementing this analysis with more (non-Western) countries would reveal whether this spread across the triangular framework is broadly visible. This would provide direction to discussions on whether exclusive politics is an immanent part of populism or whether it is originated in ideologies populism is often

Only, in the Brexit speeches the dimension-scores are more spread, suggesting that the presentation in these speeches does less match with the ideas and social allegiance. This can be an effect of the referendum but would need further investigation. 
combined with, such as nativism or nationalism (i.e., De Cleen, 2017; Mudde \& Kaltwasser, 2012; Stavrakakis \& De Cleen, 20I7; Stavrakakis \& Katsambekis, 20I4). It goes beyond the scope of this chapter to discuss this in the depth it deserves.

The speech analysis tool offers the opportunity to compare different political contexts with each other. In doing so, it affords a better understanding of populism as a global phenomenon. It also offers the opportunity to analyze populism in relation to antipopulism (Stavrakakis \& Katsambekis, 2019). Third, as emphasized by Mudde (2017), an empirically sound definition of populism is crucial to researching populism. The logic behind this method offers a Sartori-proof basis for analysis, with definitions based on clear yes-orno answers that avoid concept stretching (Pappas, 2016; Sartori, 1970; Van Kessel, 2014). These yes-or-no answers do not mean that populism cannot be mixed with other styles, but only that it is clear which part of this mix is populist and which part is not. Obama may say that "he is the real populist and not Trump"; an analysis dissecting Obama's style into three dimensions shows that the label populist is only applicable where populism overlaps with pluralism, in the social dimension. This may give him an argument to claim the title populist, but the analysis demonstrates that the label pluralist fits Obama much better.

In the end, however, also the here presented approach offers no stable answer to the question of what populism is. Politicians often mix styles and the boundary between mixed forms of populism, pluralism, and elitism is always subjective; a matter of framing. An important task of academics is to be mindful of these framings. The multidimensional approach presented in this chapter can be of help with that. 


\section{6 \\ Where the Real People Meet the Real Elite}

\section{Exploring Mixes of Populism with Elitism}
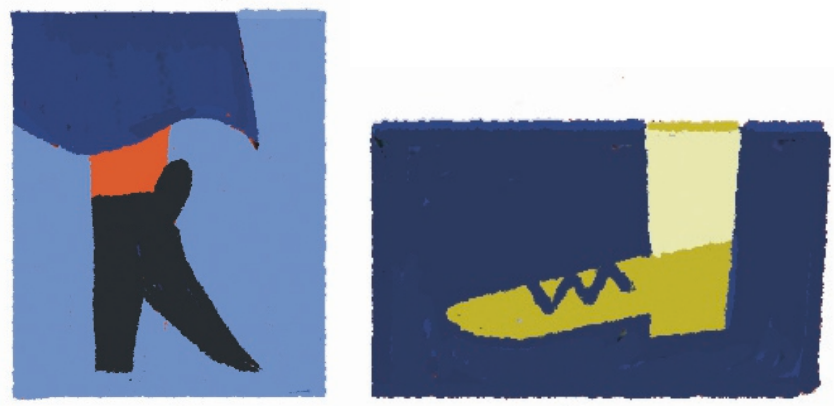

This chapter is a minor revision of: Schoor, C. (2019). Where the real people meet the real elite:

Exploring mixes of populism with elitism. Populism, 2(2), 184-206. DOI: I0.I I63/25888072-0202I032 
[Populism] is at best a phantom ideology,

a specter that can be draped over pressing

and intricate socio-political issues

in order to blur and to conceal.

Michael Freeden, After the Brexit referendum, p 10

\begin{abstract}
This chapter clarifies how elitist elements are integrated into populist discourse by analyzing political speeches using this incongruent style. First, it introduces a method to identify populist, elitist, and pluralist discourse based on a shared logic, defining populism at an intercontextual level. Second, speeches by Donald Trump (US), Boris Johnson (UK), and Thierry Baudet $(\mathrm{NL})$ are analyzed in their contexts to clarify their political styles and are then compared to see where these styles meet. The populism-elitism mix goes well with nationalism. Coalitions are created between the people and the "good" elite to fight the "bad" elite. Furthermore, the mix has rhetorical-strategic advantages, such as profiling oneself as unique on the political field. Overall, the blend shows political significance, justifying thoughtful academic consideration alongside the broad attention for full populism.
\end{abstract}

\title{
I Introduction
}

During a rally in Minnesota in June 2018, Donald Trump declared that he, and not his opponents, should be referred to as "the elite":

You ever notice they always call the other side "the elite"? The elite. Why are they elite? I have a much better apartment than they do. I'm smarter than they are. I'm richer than they are. I became President, and they didn't (Speech I0, 00:46:5I) ${ }^{23}$

The quote, which quickly traveled over the internet, left many populism researchers puzzled, as seen at On Populism, a Facebook group of populism researchers: "Confused: 
Time to drop the anti-elitism part of populism?" (Yankova-Dimova, 2018) If Trump, a paragon of populism, declares to be elite, what does this imply for the minimal definition of populism? This definition outlines populism as a set of ideas in which politicians speak in the name of a pure and homogeneous people against a corrupt elite, arguing that politics should follow the general will of the people instead of elite inclinations (Mudde, 20I7, Pp. 27-47).

Trump's speech would be better understood in a relative view on populism, such as the approach of Jagers and Walgrave (2007, pp. 319-45), who measure populism in gradations. Applying their theory to Trump's speech would deny the above quote a populist label, classifying it as mainstream. Due to many other populist speech elements, the overall style would still be characterized as populist, albeit less dense. However, the utterance is certainly not mainstream: declaring that one is more elite than "the other side" implies a strong populist division between us and them. This recalls Laclau's view on populism, which defines it as a discursive act to construct an internal divide in society between the people and the group in power (Laclau, 2005a; Stavrakakis \& Katsambekis, 20I4). However, this definition does not entirely fit either: although Trump indeed creates an internal divide in society, the constructed internal frontier lies between the people together with one elite group and a second, opposed elite group.

Another option is marking the quote as elitist because, in Schumpeter's definition of elitism, different elite groups compete with each other for leadership over the people (Mackie, 2009; Schumpeter, 2008), which applies to this quote. Labeling this fragment as elitist and other fragments as populist would characterize the speech as mixed populistelitist - a combination that is not evident. It not only contradicts the ideational definition of populism that defines populism and elitism as opposites (Mudde, 2004); it also contests the interpretation of populism as tapping into a "low" sociocultural style because elitists are more inclined to use "high" sociocultural expressions (Ostiguy, 2017). How does this incongruent combination of populism and elitism work? What purposes does it serve?

In this chapter, I aim to provide a better view of the mixed populist-elitist political style. With political style, I refer to the entire performance of politicians, consisting of three parts: first, the ideational part, expressing ideas; second, the social part, expressing social alliances, choosing political friends and enemies; and third, the rhetorical part, aiming to persuade people who are not friends yet (see Chapter 3).

To define politicians' political styles, I analyzed speeches of multiple politicians in three political contexts: the United States (US), the United Kingdom (UK), and the 
Netherlands (NL). The styles of three politicians who demonstrated a blend of populism and elitism are more elaborately analyzed: Donald Trump (US), Boris Johnson (UK), and Thierry Baudet (NL). The speech analyses are performed using a method examining political discourse as a mix of populist, elitist, and pluralist features. The approach acknowledges that populism expresses itself differently in every political context but claims that these expressions become globally comparable by defining each populism relative to expressions of elitism and pluralism. This method is grounded in a semiotic analysis, described in section 2. Section 3 describes a framework based on the revealed logic and its application in the method used. Sections 4, 5, and 6 display the speech analyses and discuss how the three politicians integrate populism with elitism. Section 7 presents a discussion of general conclusions.

\section{A Semiotic Analysis of Populism, Elitism, and Pluralism}

This section discusses a semiotic analysis, revealing the logic behind the concepts of populism, elitism, and pluralism. Before embarking on the semiotic analysis, the concepts of populism, elitism, and pluralism are briefly defined.

In elitism, the people are considered as incapable of governing themselves for various, context-dependent reasons: they are deemed to be insufficiently educated, morally weak, or too emotional. For these or other reasons, it is argued that they should have only passive democratic rights, restricting active governing to the elites of a country (Mackie, 2009; Schumpeter, 2008). This inequality is democratically justified by the argument that people have the right to dismiss leaders.

Currently, in a Western democratic context, elitist conceptions of democracy are regarded as obsolete, and most Western democracies are characterized as pluralist (Blokland, 20I I). Pluralism defines the people as a heterogeneous assemblage of individuals and groups of people. In pluralism, elite groups are viewed as just another group of people with their own interests. Competing groups share power, based on the agreement that a group or leader supported by a majority governs temporarily. Nevertheless, elitism has not been abolished altogether since in most pluralist democracies, elite members still have more access to power than ordinary people. This is a major complaint of populist politicians.

Populism is mostly seen as a set of ideas in which the pure people fight against the corrupt elite and in which democracy equals obeying the general will of the people (Mudde, 
2017). Others view populism as a political strategy to mobilize the masses against the corrupt elite. In this strategy, leaders act on behalf of the people, identifying themselves with them (Weyland, 2017). A third approach looks at populism as a sociocultural style in which the populist, like an actor, "performs" the people, mostly in a loud and vulgar way (Ostiguy, 2017). The following semiotic analysis demonstrates that these three approaches to populism are all linked, relating to elitism and pluralism in one logical structure.

The semiotic analysis provides abstract conceptual knowledge. It does not give answers about real populisms in real politics; these have to be found by analyzing these contexts, guided by this knowledge, just as grammar helps with learning a language.

Semiotics is based on structural linguistics and asserts that the relationship between words and reality is arbitrary: the meaning of a word is determined through its difference from other words. To explore these differences, structural linguist A. J. Greimas (1970/1987) devised the semiotic square, a tool to systematically break up contrary words into binary oppositions, exposing the logic behind the oppositions. Greimas saw this logic as an immanent structure behind language. However, poststructuralism has convincingly argued that this logic is part of discourse as well. In reaction to this critique, Greimas and others have affirmed that a poststructuralist use of the square is very well possible (Parret, 1989). The semiotic square has also been critiqued for being reductive, not validating the possibility of new meanings arising from new contexts (Chandler, 2002; Hébert, 2019). A poststructuralist adaptation of the square that connects different meanings in linked semiotic squares addresses this critique. To analyze populism, a linkage of squares has proven to be very useful for revealing hidden framings of the concept. This analysis explores many oppositions of populism to other concepts found in the populism literature. Only the ones relevant for the revealed logic are depicted.

First, a semiotic analysis of populism in opposition to elitism is performed (Figure 6.I, Semiotic square I). This opposition focuses the attention on aspects such as "seeing the people as morally good" versus "seeing the people as morally weak" and "capable of selfgovernment" versus "not capable of self-government." Despite their differences, the two concepts also share features: both regard the people as one group to which not everybody belongs - at least the elite does not belong to the people, but often other groups are excluded too (exclusionary politics). This shared feature is the direct opposite of seeing the people as a collection of groups to which everybody belongs (inclusionary politics, pluralism). Thus, if populism is seen as the opposite of elitism, then pluralism is the 
contradiction of what populism and elitism have in common. This contradiction is an ideational matter. This semiotic square typically depicts Mudde's definition of populism (Mudde, 2004).

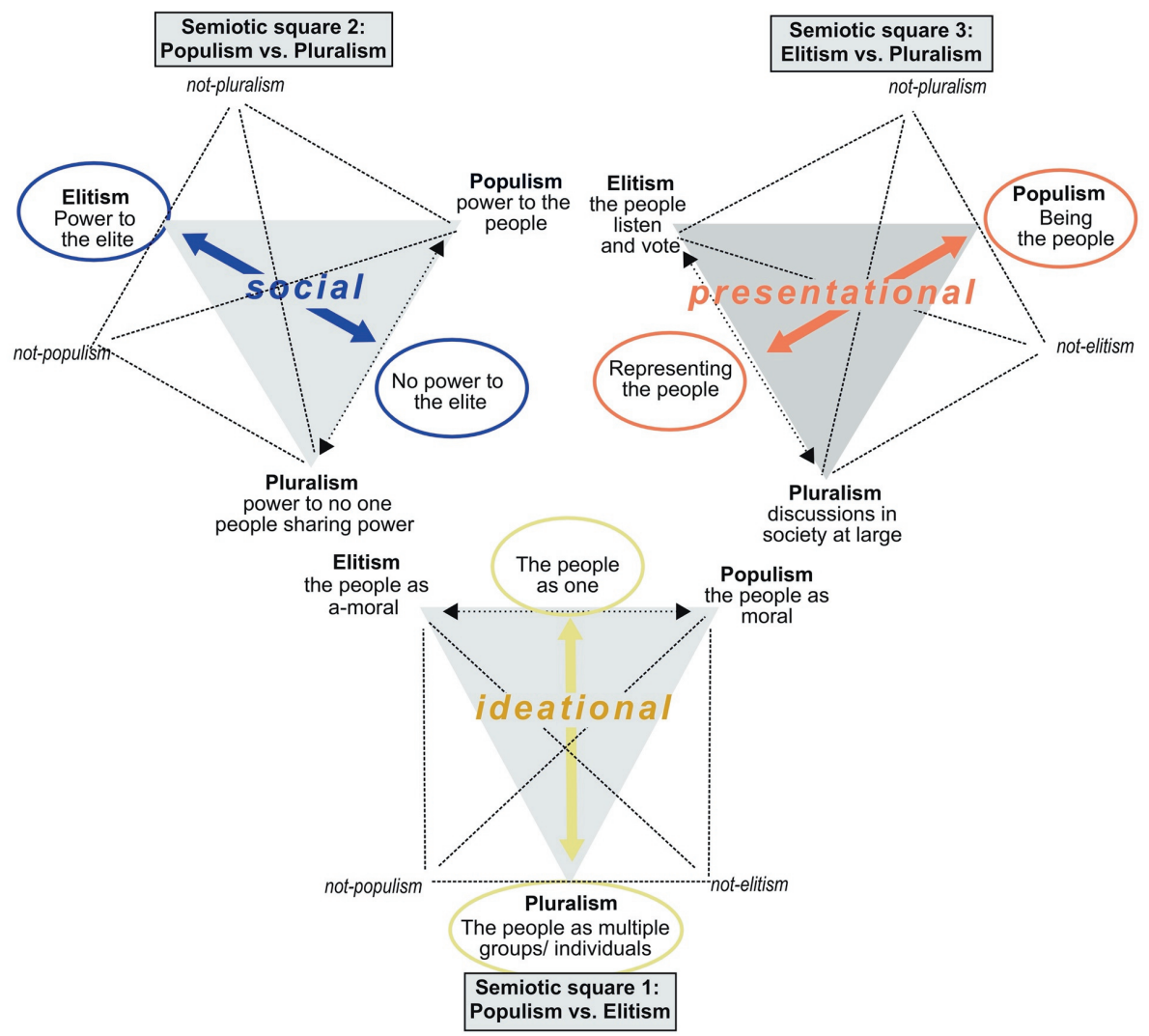

Figure 6.I A semiotic analysis of the concepts populism, elitism, and pluralism.

This definition of populism is just one possible framing, however. Another framing is revealed in Semiotic square 2 of Figure 6. I, which analyzes populism in opposition to pluralism. ${ }^{24}$ This opposition foregrounds other features, such as "the people being one" versus "the people as multiple groups" or "the populist speaking on behalf of the people" versus "the pluralist representing people." The two concepts have in common that they other. 
claim power for the people. This is opposed to elitism, which claims power for the elite. Hence, in Square 2, populism and pluralism merge at a more abstract level, opposing elitism together. This contradiction is social. This square partly characterizes Ostiguy's approach to populism, defining it as a socio(cultural) matter: by using typical (low) cultural language, populist (but also pluralist) politicians express that they are part of the people and not part of the elite, implying that their power is also power of the people.

Again, this semiotic square displays just one framing of populism. Another frame is uncovered in Semiotic square 3 of Figure 6.I, analyzing pluralism in opposition to elitism. This opposition sheds light on aspects such as "the people actively involved in politics" versus "the people only passively involved." Notwithstanding this difference, pluralists and elitists share the feature of representing the people and not speaking directly on behalf of them. The latter is a known feature of populism, in which the leader is identical with the people, not representing but being the people. This square typically depicts Weyland's "populist twist," in which the populist takes the place of the people and acts on their behalf (Weyland, 200I, 2017, p. 54). The oppositions are a presentational matter.

The logic depicted in the three semiotic squares of Figure 6.I can be formulated as the following rule:

Populism, elitism, and pluralism share one logic, dictating that the joint features of two concepts contradict the third.

Inescapably, this happens in three dimensions; if it occurred in the same dimension, populism would partly contradict itself. The three dimensions (ideational, social, and presentational) broadly align with the three main approaches to populism mentioned earlier in this section (Kaltwasser et al., 2017; Mudde, 2017; Ostiguy, 2017; Weyland, 2017). They also match the three parts of political style mentioned in the introduction and Chapter 3 of this dissertation.

In the populism literature, populism is also opposed to other concepts, such as liberalism, technocracy, or pragmatism (Canovan, 1999; Moffitt, 2016; Pappas, 2016). These 
oppositions are explored as well and can all be related to the logical framework. They are not depicted here because that would require too much space. ${ }^{25}$

\section{A Triangular Framework for Political Analysis}

The three semiotic squares discussed in section 2 are integrated into one triangular framework, as depicted in Figure 6.2. Because the semiotic analysis defines populism in relation to elitism and pluralism within the language system, the framework is applicable in all contexts in which these three concepts, or their equivalents, are meaningful. This is the case in many languages; the concepts are widespread because their etymological roots are Latin.

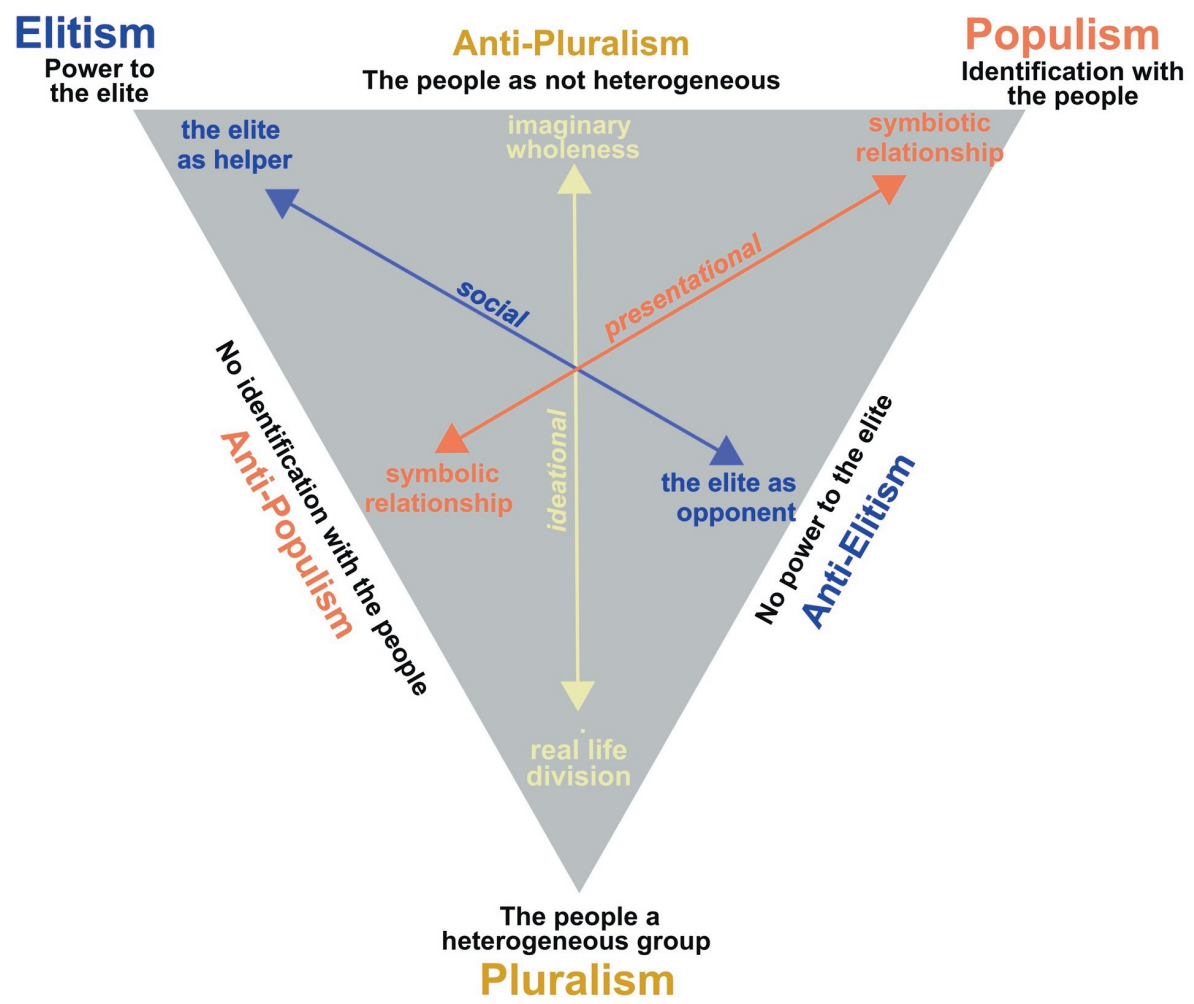

Figure 6.2 A triangular framework, depicting the logical ties between populism, elitism, and pluralism at three levels. 
The corners of the triangle represent the pure styles: populism, elitism, and pluralism. The sides represent the mixed styles, defined as the anti-styles of the style at the opposite side of the triangle. The middle of the triangle represents a blend of all three styles. More specifically:

- The mixed elitist-populist style is logically the anti-style of pluralism. Separately, populism and elitism only partly oppose pluralism (and each other); it is in their shared features that populism and elitism linearly oppose pluralism. This opposition is an ideational (cognitive) matter: between acknowledging that the people are divided (pluralism) or not (populism and elitism). In the latter, an imaginary wholeness of the people replaces a realistic acknowledgment of people not being all the same.

- The mixed populist-pluralist style is logically the anti-style of elitism. This opposition is social and views the elite either as the helper of the people (elitism) or not (pluralism and populism). Elitism claims power for the elite with the support of the people; antielitism claims direct power for the people(s).

- The mixed pluralist-elitist style is logically the anti-style of populism. This opposition is presentational. One side (pluralism and elitism) acknowledges that politicians have a symbolic relationship with the people-they represent the people. The other side (populism) speaks on behalf of the people as if they are the people instead of representing them from a distance. It goes without saying that this symbiotic relationship is imaginary.

Although all styles partly overlap (see Table 6.I), the binary opposition between the style and its anti-style gives a Sartorian yes or no answer to what populism (elitism, pluralism) is and is not (Sartori, 1970). This makes this logical framework broadly useful for social research on populism and political style. 


\begin{tabular}{|l|l|l|l|}
\hline $\begin{array}{l}\text { Presentationa } \\
\text { I }\end{array}$ & $\begin{array}{l}\text { Elitism } \\
\text { No identification with } \\
\text { the people } \\
\text { (Representation) }\end{array}$ & $\begin{array}{l}\text { Po identification with } \\
\text { the people } \\
\text { (Representation) }\end{array}$ & $\begin{array}{l}\text { Identification with the } \\
\text { people (Presentation) }\end{array}$ \\
\hline Ideational & $\begin{array}{l}\text { The people not as } \\
\text { heterogeneous } \\
\text { (Exclusionary) }\end{array}$ & $\begin{array}{l}\text { The people as } \\
\text { heterogeneous } \\
\text { (Inclusionary) }\end{array}$ & $\begin{array}{l}\text { The people not as } \\
\text { heterogeneous } \\
\text { (Exclusionary) }\end{array}$ \\
\hline Social & $\begin{array}{l}\text { Power to the elite } \\
\text { (Politicians part of the } \\
\text { elite) }\end{array}$ & $\begin{array}{l}\text { No power to the elite } \\
\text { (Politicians part of the } \\
\text { people) }\end{array}$ & $\begin{array}{l}\text { No power to the elite } \\
\text { (Politicians part of the } \\
\text { people) }\end{array}$ \\
\hline $\begin{array}{l}\text { Bold : unique feature | Regular: shared feature | Two features of one style imply the } \\
\text { third, in every order. }\end{array}$
\end{tabular}

Table 6.I Main features of populism, elitism, and pluralism in relation to each other.

This logical structure has been applied to an analysis instrument to assess political styles in speeches. The instrument builds on a method described in Chapter 3. The main innovation is a triangulation of the formerly linear scale, following the logic explained above. The method recognizes three dimensions based on the semiotic analysis. They align with the three ideological dimensions of Van Dijk, used in the former version of the method (Van Dijk, 1998). Subsequently, each dimension is divided into five style elements in which politicians can differentiate from each other on the political stage (see also Chapter 3):

I The people (pure whole / amoral whole // not whole),

2 The elite (pure whole / amoral whole // not whole),

3 Democracy/government (power to the people / power to the elite // no power to one group),

4 Politics (conflict / harmony // compromises and overlapping consensus), and

5 The political context (focus on crisis / focus on success // focus on facts).

The five elements figure in various populism definitions, although it is argued that (5), the proclamation of a crisis, and (4), a polarization style, do not belong to the core of populism but are context-dependent expressions (Rooduijn, 20I4). Nevertheless, all five elements can be regarded as core elements of political style, which is broader. To assess the distinct roles of separate style elements, the speech analysis method accommodates analyzing the scores of each element separately, validating possible differences. The speeches are first coded according to the detailed features of the analysis instrument. The computer assembles all coded fragments under the fifteen sub-elements (five elements at three levels) to let the 
analyst interpret them in relation to each other and to the context. Subsequently, average political (sub)styles can be plotted on a triangular field based on the triangle in Figure 6.2.

With the help of this method, speeches of Donald Trump, Boris Johnson, and Thierry Baudet held between 2016 and 2019 are analyzed. Their styles are discussed in the following sections and depicted in Figure 6.3. Styles of competing politicians are depicted as well (based on speeches I- 3 I in Appendix A) These styles primarily function to discuss the populist-elitist style in its political context and are not examined further.

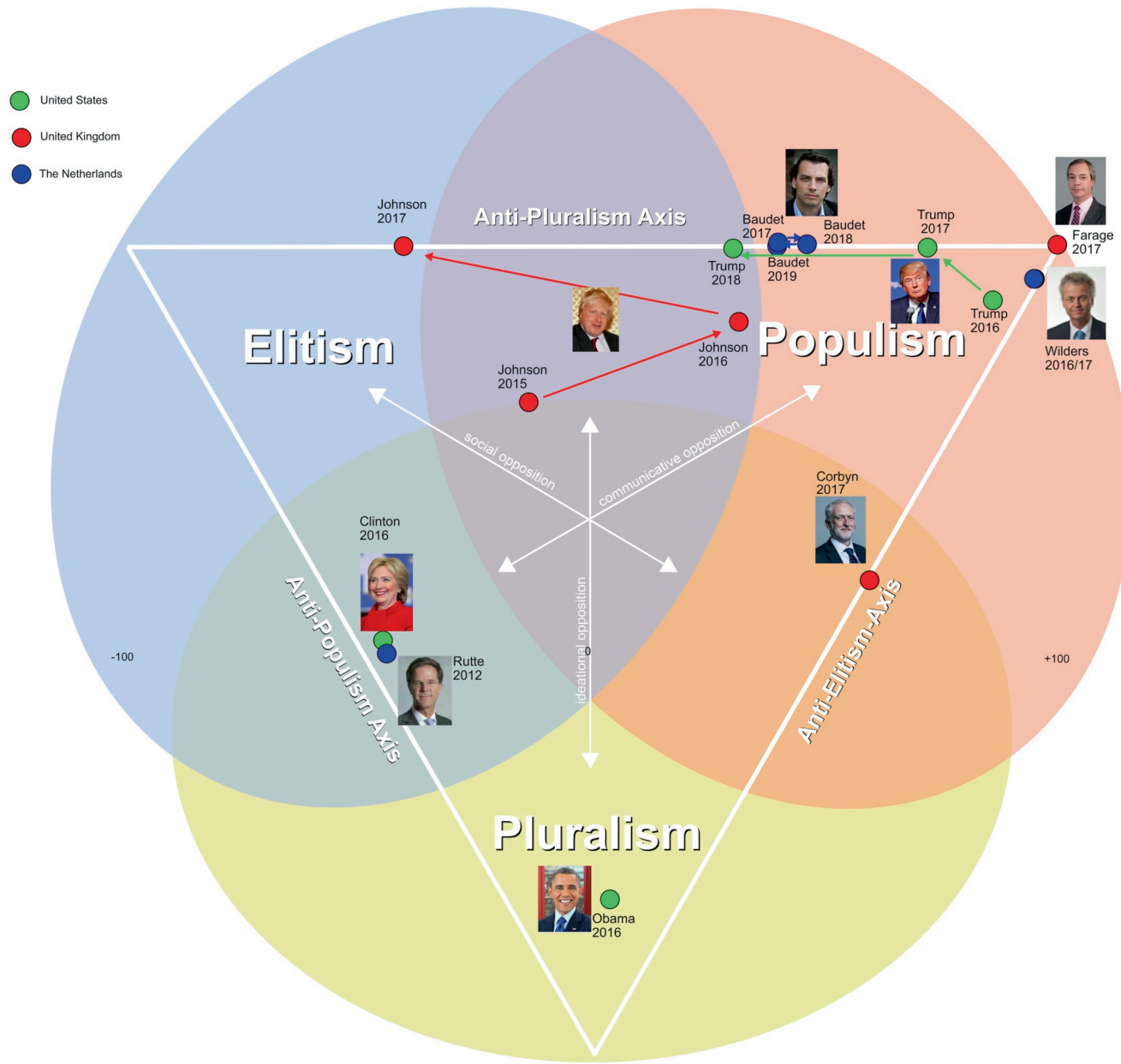

Figure 6.3 The political styles of speeches plotted on a triangular framework based on the logic between populism, elitism, and pluralism 


\section{Donald Trump: A People's President for an Elite People}

In the US, Donald Trump surprisingly won the presidential elections in 2016 with a clear populist performance - a style that he has maintained during his presidency. Trump's populist style is broadly acknowledged and is confirmed by the analysis of speeches held in 2016, 2017, and 2018, presented in this chapter (Speeches no 7, 8, 9 and 10) ${ }^{26}$. The analysis also shows a development: as displayed in Figure 6.3, his style slowly moves toward elitism. In 2016, the style is populist with a small pluralist touch. In 2017, it becomes fully populist, and in 2018 , it is characterized as mixed populist-elitist. This section looks at this development in more detail.

The pluralist touches in 2016 can be interpreted as a response to the electoral environment, as they have disappeared in 2017 and 2018. Populism, on the other hand, is a constant factor in Trump's style. In 2016, 2017, and 2018, Trump underscores his belonging to a homogeneous people, mainly through using a populist "we" in combination with nationalist ideology-expressing a shared love for America, the flag, American football, traditional American food, and American history:

We're standing on the shoulders of great American patriots who put down the railroads, built up the highways, and dug out the most amazing Panama Canal, losing thousands of lives in doing it (Speech 10, 00:56:03).

In all speeches, Trump displays himself as part of the good and real people while he is also a billionaire. Within the American context, this is plausible because of the promise of the American dream: everybody can make their way up in society. The fact that Trump is part of the new rich, ostentatiously showing off his wealth and power, and not part of the polite and well-mannered old elite, enhances his image as a self-made man, originally belonging to the people. It recalls Ostiguy's characterization of populism as tapping into low socialcultural expressions (Ostiguy, 2017), which, in the semiotic approach of this dissertation, refers to the social level of political style: it is used to show oneself as part of the people.

\footnotetext{
${ }^{26}$ Numbers refer to the speeches listed in Appendix A.
} 
Trump's attitude toward the elite is less consistent. In 2016, he is part of the wealthy one percent billionaire class that others call the elite. However, he actively denies being elite, saying that he "used to belong to the bosses, but not anymore" and depicting himself as a “worker" (Speech 8, 00:I I:59, 00:53:45). In 2017, his attitude toward the elite stays the same: although he is undeniably part of the elite (social level), his language (presentational level) and his ideas and values (ideational level) remain populist. For instance, he does not directly endorse the Republican candidate in the special senate election in Alabama but only-in a populist manner-attacks his Democratic opponent. Only element (5), the political context, changes into half elitist. He still refers to the context as a "disaster" or "huge crisis" (populist), but he also claims success. Success is the logical opposite of a crisis, hence not populist. Because the utterances are also highly aggravated, they are assessed as elitist (looked at with more nuance, they could also be pluralist). The style change away from populism is inherent to his new role as president: if Trump maintains that the entire political context is a disaster, this would be partly his fault.

The small style changes toward elitism in 2017 further evolve in 2018 , resulting in a total of thirty percent elitist-style elements and a mixed populist-elitist style. This shift is mostly because of two elements. The first is, as in 2017, the claim of political success. Second, Trump no longer depicts the elite as entirely bad. There is still a bad elite (“Crooked Hillary”), but Trump now also endorses a "good” elite: the Republican candidates he rallies for. In contrast to the 2017 Pensacola rally, he now elaborately praises the Republican candidates, who are established politicians that clearly belong to the political elite. Also, Trump no longer denies his own elite membership, as shown in the quote with which this chapter opens.

The question arises of how Trump combines being part of the people with his elite membership. The 2018 Minnesota speech shows three ways in which this happens. First, Trump makes the people part of his success. This way, the people govern themselves (populist) through his elite rule (elitist):

And all over Asia-[applause]—and all over Asia they're celebrating the great achievement that we made because you were the ones that put me here. We made - that we made all over Asia. So you should be very proud of yourselves for what took place. (Speech 10, 00:18:10). 
Second, when Trump speaks in a remote (non-populist) "they" about the people or in another way uses an elitist style-which happens regularly - he often abruptly changes his style into a populist one. For instance, while praising a Republican candidate for his work, he mentions that this candidate loves ice hockey-which expresses closeness to the people. Or when he claims success, he immediately attacks the "fake" media for not recognizing this. Trump seems to tune the tone of his speech: when he expresses distance from the people, he compensates for this with a populist remark.

A third way in which Trump reunites the people with the elite is by analogy. In the following fragment, the people are denied their status as real people (they are called "the deplorables") in the same manner that Trump is denied his status as real elite. Therefore, in their shared relation to the "other side," they are the same:

And believe me, our people are the smartest and the hardest working. Smarter than anybody, and the hardest working. You know, a little thing I was talking about today. You ever notice they always call the other side - and they do this on - "the elite'? The elite. Why are they elite? I have a much better apartment than they do. I'm smarter than they are. I'm richer than they are. I became President, and they didn't. And I'm representing the greatest, smartest, most loyal, best people on Earth, the deplorables. Remember that? The deplorables. (Speech 10, 00:46:28)

The fragment, a part of which was displayed in the introduction of this chapter, reverses the status of the elite and the people: the people are now the elite (in other speeches in 2018 and 2019, even the super elite) together with Trump, and the old elite members are defined as fake elite. Apart from what this says about Trump's personality-it suggests a deep frustration about not being recognized by the old elite- there is more to this reversion. Trump draws a new line in the political field: between the so-called "real" elite together with the "real" people and the non-people (immigrants) together with the non-elite (Democrats), allowing him to maintain his populist style while being president. 


\section{Boris Johnson: Letting the People "Roar"}

Since the referendum in 2016, British politics has been dominated by the discussion of whether Britain should leave the EU. Boris Johnson, a conservative politician, was one of the main pro-Brexit players during the referendum campaign in 2016. His Brexit message has broadly been interpreted as nationalist and populist, but simultaneously, he presented himself as an Etonian and a liberal cosmopolitan with ancestry related to European royaltyan elite background that he likes to mock. The speeches analyzed here, held in 2015, 2016, and 2017 (Speeches 14, 15, and 16) confirm Johnson's mixed elitist-populist style: to different extents, his speeches mix elitism with populism. They are on average more elitist than populist (see Figure 6.3) and demonstrate two substantial shifts in political style over time.

First, his style during the 2016 Brexit campaign is strikingly more populist than before or after. This is mostly due to two of the five style elements. In elements 4 Politics, and 5 The political context, his style shifts from mixed populist-elitist in 2015 to mostly populist in 2016 and back to mixed populist-elitist in 2017. In all three speeches, he speaks in a populist style of politics as a fight and uses strong, aggravated language that polarizes the debate, with words such as "deeply skeptical," "subterfuge," "seriously compromised," and “very worrying” (Speech 15: 00:01:06, 00:03:29, 00:04:37, 00:07:27). In 20I5 and 2017, however, besides populist-style elements, he also emphasizes in an elitist style that politics is cooperation: for instance, Britain is a "team player" (Speech 16, 00:16:15), and the Conservatives are "bringing people together" (Speech 14, 00:05:37). The idea that "politics is cooperation" is absent in the Brexit campaign speech. In element 5 The political context, the same pattern is visible: in 2015 , Johnson abundantly claims successes as the mayor of London (elitist), and in his 2017 speech, he also focuses, as Minister of Foreign Affairs, on progress and success. In his Brexit campaign speech, success claims are absent: he solely proclaims a crisis. The crisis also figures in the 2015 and 2017 speeches but much less dominantly so. The shift from elitism to populism and back can be understood as related to the referendum campaign. The clear yes or no question of the referendum automatically implicates a polarization of the debate, and it is to be expected that elements 4 and 5 are most affected by this. Another possible factor is a change in political role: in 2015 and 2017, Johnson is in a governing position as mayor and secretary of state, whereas in 2016, he is in 
parliament. In the latter role, one is supposed to be critical of the government. However, since his party is governing, the referendum is a more plausible explanation.

A second style shift in Johnson's political style is that it becomes less pluralist. Most saliently, this movement away from pluralism is visible in style elements I The people, 2 The elite, and 4 Democracy; pluralist features are only present in 2015. The above reasons cannot completely explain this because the change continues after 2016. Looking closer at the speeches, it becomes clear that Johnson's partly pluralist conception of the people in 2015 has changed into a homogeneous one in 2016 and 2017. The group is good (populist at the ideational level) but does not govern itself (elitist at the ideational level). Therefore, Style element I The people, is mixed populist-elitist at the ideational level. Johnson is not part of the people; he is part of the elite, so at the social level, Style element I is elitist. This elite works together with the people, as in this fragment:

We are not the lion [symbol of England]. We do not claim, like some others, to be the lion. That role is played by the people of this country. But it is up to us now-in the traditional non-threatening, and genial, self-deprecating way of the British-to let that lion roar. (Speech 16, 00:28:01)

This quote, from 2017 , is very much elitist, as it not only depicts the people as a remote entity but even uses a metaphor of the people as a captured animal controlled by man. One explanation for this movement toward anti-pluralism is that it reflects a change in Johnson's worldview: apparently, Johnson's ideas have become more anti-pluralist. Another explanation is political-strategic. The ongoing struggle over Brexit in 2017 forces Johnson to maintain that the British people are one; saying that the people want Brexit is more persuasive than saying that slightly more than half of voters want Brexit.

Average scores at the ideational, social, and presentational dimensions confirm the strategic/rhetorical explanation, only in reverse. The scores show that in 2015, Johnson's presentation is much more pluralist than the ideational and social dimensions. In 2017 , the three dimensions come much closer, suggesting that Johnson's ideas have not become more anti-pluralist over the years but that his social allegiances and presentation have. His ideas have been mainly elitist (and anti-pluralist) all along. 


\section{Thierry Baudet: Showing Off with Superiority}

Dutch democracy has been shaken up by populist tendencies during the last decades, most visibly by the presence of Geert Wilders's Freedom Party since 2004. In 2017, a new populist party entered politics, rapidly gaining influence: the Forum for Democracy. Its leader, Thierry Baudet, is a young (former) academic with a doctorate in law. He got involved in politics through a referendum campaign against an EU treaty with Ukraine in 2016, which he won. The EU, however, did not withdraw the treaty but accepted it with a side letter from the Netherlands. This "undemocratic decision" led Baudet to start a political party, just a few months before the parliamentary elections in March 2017. Its program is mainly right-wing, nationalist/nativist, anti-EU, anti-politician, and anti-immigrant. Baudet won two of the one hundred fifty parliamentary seats, and his party has moved up in the polls since. In March 2019, in the combined provincial and senate elections, Baudet won twenty percent of the vote; in the scattered political landscape of the Netherlands (with thirteen political parties in parliament), his party even became the largest in the Dutch senate.

The analyzed Baudet speeches, from 2017 to 2019 (Speech 24, 25, 26, 27 and 28) demonstrate an unmistakable mixed populist-elitist style, just staying within the pure populist range, as visible in Figure 6.3. His average score comes close to Trump's, and like Trump, he expresses himself as part of the people and part of the elite. But there is one significant difference: Trump mostly taps into low cultural expressions, displaying his wealth and power in a loud and vulgar way. Baudet mostly taps into high cultural expressions, using intellectual language, loving literature and classical music, and even moving his grand piano with him into parliament after his election. In Ostiguy's definition, only Baudet's nativism can be regarded as low (Ostiguy, 2017, p. 8I). His victory speech in March 2019 contains references to Hegel, and his maiden speech in parliament starts with a few sentences in Latin.

This raises questions about Ostiguy's (2017) definition of populism as tapping into low culture: how does Baudet's clear populist message combine with his display of high culture? A closer look at the separate style elements shows how Baudet assembles his particular style. The mix mostly occurs in four of the five style elements. His style at Element 5 The political context, stays solely populist: he depicts in highly aggravated language the situation in the Netherlands as an extreme crisis, "a perfect storm" created by the elite, 
causing the total destruction of Dutch culture and Dutch people. At the same time, the other style elements combine populism with elitism.

In Element I The people, Baudet has a fully populist idea of the people as whole and good, excluding immigrants and the political elite; the mixed populist-elitist style only occurs at the social and presentational levels. For instance, he speaks in a populist "we" on behalf of the people but also portrays himself as far better than "people who haven't read a book in their entire life" (Speech 28, 00:02:22). He states that "we are one Dutch people" while referring to high culture such as Rembrandt and Spinoza. He reconciles the two by describing the Dutch (and European) culture and its people as high class. Hence, like Trump, he connects an elite people with an elite leader.

In Element 2 The elite, Baudet's average style is mixed populist-elitist at all levels. He is extremely anti-political establishment, depicting politicians as incapable and solely interested in their own interests (populist) (Speech 27, 00:21:55). However, he also presents himself and his party as "the new elite," there to replace the old, corrupt elite (elitist) (Speech 24, 00:10:38). The two different styles do not contradict each other because competing elite groups are a component of elitism.

In Element 3 Democracy, there is a movement from pure populism toward mixed populism-elitism. The ideational level stays populist in three speeches, passionately condemning current democracy as flawed and defending the binding referendum. On the social and presentational level, his style is more mixed. Socially, Baudet depicts his party as a movement directly coming from the people, but his presentation contradicts this: parts of his speeches resemble lectures, in which he explains as a professor how the country should be ruled in a remote, elitist way.

The same contradiction is visible in Element 4 Politics. On the one hand, Baudet sees politics as "a war" against the corrupt elite (populist): "If all these matters hadn't happened, I would never have entered politics. But we have been called to the battlefront. Because we have to. Because our country needs us" (Speech 28, 00:1 I:46). But he also sees it as cooperation with other parties (elitist):

Madness, madness, what are we thinking? We have to end that. (...) Unfortunately, we cannot end it with the rhetoric of Geert Wilders. Because that rhetoric is too destructive; it is not unifying enough to gain a foothold in the Netherlands. It is like 
shouting from the sidelines, channeling resentments that, subsequently, have nowhere to go. (Speech 25, 00:28.21)

After his electoral victory in 2019, his determination to cooperate will be tested. Baudet says that he is prepared to cooperate with all parties (Speech 28, 00:21:06). However, he also proclaims to be against making compromises. Compromises are not needed, according to Baudet, because he is right, and other parties will just have to agree. Cooperation therefore mainly consists of other parties following "his flagship of the Renaissance." (Speech 24, 00:12:00). This narrative contains a large amount of wishful thinking or shows that Baudet is not really interested in cooperation.

The political styles of Baudet's speeches (held in 2017, 2018, and 2019) approach each other relatively closely-closer than Trump's and Johnson's speeches. This can be explained by the unchanged nature of Baudet's political situation during the assessed period, whereas Trump's and Johnson's political situations changed. Baudet's style did not have to adapt to a different purpose fitting a new situation. The main purpose was establishing his position in the Dutch political field. For this, he had to differ from mainstream parties but also from an established populist party, the Freedom Party of Geert Wilders. On the one hand, Baudet profiles himself as being more cooperative than Wilders (elitist). Against Prime Minister Rutte, he claims to be smarter, a real elite, and exposes Rutte as fake elite, calling him an "economic nitwit." (Speech 28, 00:03:16). At the same time, the political context is a "disaster" (populist), and democracy and the political elite are corrupt (populist). Hence, with his populist-elitist style, Baudet creates his unique selling point: he is more likely than Wilders to realize his promises by cooperating in a government-in the Netherlands, governing always means cooperation. At the same time, he is, like Wilders, not part of the political establishment.

Since Baudet has gained more political power, the consistency of his style will be tested. Inconsistencies, however, can be compensated for by his nationalist ideology. As all political styles analyzed in this chapter show, this ideology goes well with the populist-elitist style. It unites the elite and the people with the help of a second concept: the nation. 


\section{Conclusion and Discussion}

This chapter demonstrates that Donald Trump, Boris Johnson, and Thierry Baudet combine populism with elitism as their political styles. The usage of their styles fluctuates in time and serves different purposes.

While Trump's style was predominantly populist before he was elected president of the US in 2016, speeches held in 2017 and 2018 show a slow movement toward elitism. As president, Trump continues to create a populist internal frontier within American society. However, the opposition is no longer between the people and the elite and immigrants; the new divide is between the real people together with the real elite and the bad elite and immigrants. This shift allows him to embrace his elite role as president while remaining part of the real people.

In the UK, Boris Johnson's political style between 2015 and 2017 shows two changes: one from mixed elitism-pluralism to full anti-pluralism and one from elitism to populism and back. The populist move can be interpreted in light of the polarization effect of the referendum, whereas the movement toward anti-pluralism partly can be understood as strategically- rhetorically motivated: within the ongoing Brexit debate, it is much more persuasive to state that the (non-pluralist) people voted as one for Brexit than that only slightly more than half of the people voted for Brexit. Besides, the analysis shows that Johnson's presentational style before Brexit was more pluralist than his ideas and that the elitist-populist style is more internally coherent.

In the Netherlands, Thierry Baudet consistently has a mixed populist-elitist style, combining a plain populist message with an intellectual elite image. The style combines well with Baudet's nationalist and nativist message. Moreover, it has the strategic benefit of positioning him advantageously in the political field: as different from mainstream politicians and from the dominant populist player in the Netherlands, Geert Wilders.

The style analysis suggests directions toward more general conclusions, which would need further investigation.

- The success of all three politicians indicates that the combination of populism with elitism is rhetorically powerful. An explanation is that the style combines the advantages of an elite identity, which is traditionally associated with a governing role, with the membership of a large group. Social psychology has shown that the fact that one belongs 
to a group (white or black, American or British, or just group A or B) already has the effect of favoring in-group members over out-group members (Ellemers \& Haslam, 2012; Turner \& Reynolds, 2012). For political style, it follows that there are electoral benefits to styling one's political identity as belonging to a large group. Additionally, being part of both an elite group and the people appeals to even more voters-people who do not identify themselves with the real people might be attracted by a persona with an elite identity.

- As the three politicians combine a populist-elitist style with nationalist ideology, it is worth investigating this combination further. Nationalism does not need to be combined with populism-elitism. There are ample examples of politicians combining full populism with nationalism, and pluralists express nationalist ideas as well, uniting the plural peoples under one flag, as, for instance, Barack Obama (Speech I, 12:03:00). On the other hand, it is plausible that populism-elitism has to be combined with another uniting principle. Nationalism and nativism can have that function, or just anti-pluralism might be enough. Even the use of certain unifying metaphors, such as speaking of the people as a family or a herd, could work.

- Similarly, the relationship between authoritarian populism and populism-elitism is worth investigating further. The analysis shows that Trump, an authoritarian populist, uses elitist elements to establish his authority, but reversely, not all populist-elitists can be characterized as authoritarian-Boris Johnson is not an authoritarian but a liberal. The difference between Johnson and Trump, with the former more elitist than populist and the latter more populist than elitist, possibly has to do with this. Further exploration can clarify this relationship.

- The construction of an elite people, as done by Trump and Baudet, is the point where the mix defies democratic boundaries. A populist definition of the people as "good" and "capable" stays neatly within democratic limits. It even is, as argued by many populism researchers, a correcting mechanism in democracies becoming less democratic. Also, an elitist definition of the elite as "elite leaders chosen by the people" is democratically justified as long as this elite is accessible to new people, as, for instance, in a meritocracy; the people are free to choose whomever they see as best. However, suggesting that people choose their best leader also means "being the best people" is demagoguery - it is a fallacy in the classical definition of Aristotle- "presenting things as the same that are not." In a populist presentational style (see section 3), this fallacy is 


\section{CHAPTER 6}

implied: populist leaders present themselves as the people, entailing that if the leader is elite, the people are as well. In classical Athens, Aristotle attempted to fight these kinds of fallacies in his Rhetoric (Aristotle, trans. 1984; Chapter 7). His work may offer further direction for handling this.

To end this chapter with an optimistic conclusion, over the last decades, populism research has been devoted to resolving the puzzle of what populism is, leading to the substantial growth of insights into populism. The semiotic analysis performed in this dissertation would have been impossible without them; it is the result of analyzing many oppositions that have been put forward in the populism literature. The framework that emerges from this analysis can be of help in further solving the populism puzzle, as it brings together the three main approaches to populism and explains how they interact (Kaltwasser et al., 2017). Of course, this abstract conceptual knowledge does not provide answers about real populism in real politics. Nevertheless, as shown in the analyses in this chapter, the logical structure can be helpful in understanding and comparing different contextual meanings of populism. 


\title{
7 \\ Political Metaphor, a Matter of Purposeful Style
}

\author{
On the Rational, Emotional, and Strategic \\ Purposes of Political Metaphor
}

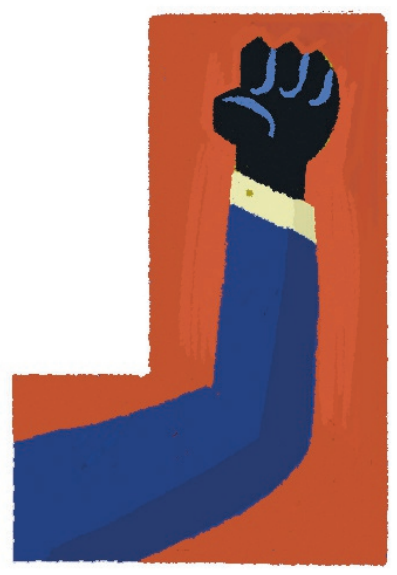

This chapter is a minor revision of: Schoor, C. (20I5). Political metaphor, a matter of purposeful style: On the rational, emotional, and strategic purposes of political metaphor. Metaphor and the Social World 5(I), 82-I0I. DOI: I0.1075/msw.5.I.05sch 
... listen to my simile, and you'll

appreciate all the more how

greedy for images I am.

Plato, The Republic, VI, 487e.

\begin{abstract}
In this chapter, I returned to Aristotle's original definition of metaphor in order to set up a framework for the analysis of political metaphors with a focus on rhetorical style. Style is significant, because using a political metaphor is performing a political speech-act, and an important purpose of that speech-act, besides persuasion, is establishing a political identity and style. I first designated the exact position of Aristotle's theory within conceptual metaphor theory, in order to avoid a lack of coherence between classical and conceptual metaphor theory. In the combination of the two theories, I was able to define three styles of purposeful political use of metaphor: a ratio-based, an emotion-based, and a strategy-based usage of (conceptual) metaphor. Examples of the three metaphor types show how they can be identified in political discourse. The framework can be helpful in further political analysis to assess what the role of rhetorical/presentational style is in political processes.
\end{abstract}

\title{
I Introduction
}

The repetition of "I have a dream" in Martin Luther King's famous speech; Margaret Thatcher's turning of the negatively-intended nickname "Iron Lady" into something to be proud of; Barack Obama's allusions to the American Dream: these examples all show that political persuasion is not a matter of conceptual metaphor or metaphorical thought alone. Most often, metaphors are used in combination with other rhetorical strategies such as repetition, inversion or hyperbole, which makes it necessary to combine conceptual metaphor analysis with classical rhetoric, as has been argued by Jonathan Charteris-Black (2005, p. 29, 2009, pp. 99-100).

The need to look further than the conceptual level of metaphor in discourse was also expressed by Gerard Steen when he proposed to acknowledge three dimensions of metaphor: he argued that besides the conceptual and language dimension, the communicational dimension should be taken into account. A metaphor used for special communication purposes is different from a metaphor that is unintentionally used. According 
to Steen, this would "reinstate the traditional distinction between metaphor as a tool for rhetoric versus metaphor as a tool for more general concerns of language and thoughts" (Steen, 2008, p. 238).

So rhetoric is back in metaphor theory, but the application of classical rhetoric in combination with conceptual metaphor analysis is not evident, as during the last few decades many scholars have emphasized the contradiction between conceptual metaphor theory and the classical view on metaphor. Although this contradiction has been revealed as a misreading of Aristotle (see section 3), the supposed inaccuracy of classical metaphor theory is still in the air, and at the very least the two theories suffer from a lack of coherence.

For example, in his analysis of political speeches, Charteris-Black uses all the classical definitions of rhetoric except that of metaphor. In a list of classical rhetorical tropes, the description of metaphor is tacitly replaced by a new one, which is clearly inspired by modern notions on metaphor (20l4, p. 46). This may very well serve its analytical purpose, but it also raises questions such as: if Aristotle's conception of metaphor is a fallacy, then why should his other rhetorical concepts be correct? Or, conversely, if Aristotle's metaphor concept is not a fallacy, then why replace it? Most probably, Aristotle's description of a metaphor just gives an answer to a different question than the questions modern metaphor theorists are concerned with. Changing the frame in which the concept of metaphor is placed also means changing the questions that are answered, so it might be meaningful to see what question it is that Aristotle's description of a metaphor gives an answer to.

In this chapter, I will return to Aristotle's original definition of metaphor. To avoid inconsistency, I will first designate the exact position of this definition within conceptual metaphor theory and see where the two theories meet. At their meeting point, three kinds of rhetorical purpose of metaphor will be distinguished: a reason-based, an emotion-based, and a strategy-based persuasive purpose. Focussing further on the political use of metaphor, this framework is more useful than previous frameworks because it offers a determination of rhetorical style. Style is important, because using a political metaphor is performing a political speech-act, and - besides persuasion - an important purpose of that speech-act is establishing a political identity and style. For example, a politician can choose to use highly provocative metaphors or very sophisticated ones, with the aim of establishing different political identities and addressing different opponents and/or supporters. This chapter acknowledges three rhetorical political styles, based on what is (for the public) the main 
obvious use of a political metaphor. This distinction is important for further political analysis, to assess what the role of rhetorical style is in political processes.

\section{Rhetoric and the Debate on Metaphor in Discourse}

For a long time, classical rhetoric was absent from the academic discussion on metaphor. Since the 1980s, many researchers have considered metaphor first and foremost as a conceptual process, traces of which could be found in language (Lakoff \& Johnson, 1980). Steen has recently argued that metaphor is also a matter of language and communication (2008) and accordingly proposed a threefold distinction of metaphor usage: metaphor in thought, metaphor in language, and metaphor in communication. To distinguish a metaphor in language and thought from a metaphor in communication, Steen proposed to look at the deliberate or non-deliberate use of a metaphor. When a metaphor was produced deliberately and/or conceived as a deliberate metaphor, there would be a special communication function. When it was used non-deliberately, it would be mere language and thought.

In response to Steen, Raymond Gibbs stated that the distinction between metaphor in thought, language, and communication is indeed important, but that deliberate metaphors are not as deliberate as they seem and do therefore not essentially differ from other metaphorical language use (Gibbs, Jr., 20II). Another reaction came from Charteris-Black, who stated that the notion of "deliberateness" focuses too much on the intentions of the sender of the message, which is an uncertain area to enter; a researcher can never know for sure what the intentions of the sender are and even the sender himself may not be fully aware of his intentions at the moment of speaking (Charteris-Black, 20I2). In the case of persuasive language, Charteris-Black proposed the term "purposeful" instead of "deliberate," as this would characterize persuasive language as a "speech-act" (performing an action by speaking, Austin, 1962), and focus on the whole action of persuasion. For persuasive texts at least, this would be a better term, since persuasive language is always uttered with a purpose or a plan, with an effect on the audience in mind. Even when the purpose was not deliberately intended, it would still be purposeful language if the effect was persuasive (Charteris-Black, 2012, p. 17).

Charteris-Black does not differentiate between political language and other persuasive language. Nevertheless, the purpose of a political speech-act differs from other 
persuasive speech-acts; besides a persuasive purpose, there is also the purpose of establishing a political identity. With the choice of language, a politician takes a position within the political field, chooses his political friends and opponents, and establishes power (Martin, 2013, p. 10). So, politicians rarely if ever aim at persuasion alone; they have to make enemies as well as friends, as they want to represent a group of people, and these people need to be able to identify themselves with a politician. This makes politics, in essence, a creative activity, affected by style and taste (Ankersmit, 1996, p. 54). What is persuasive for one section of the public can be extremely repulsive for another.

To define this rhetorical political style, Aristotle is an interesting source, since he was concerned with the difference between the emotional rhetorical style of the Sophists and the more rational rhetorical style he himself endorsed. His distinction between three means of persuasion - logos (the plain argument), ethos (the character of the speaker) and pathos (the emotional appeal on the audience) (Aristotle, trans. 1984, Rhet I377b2 I) - offers a good starting point for an analysis of style, as different use of these means distinguished a Sophistic style from a deliberative style. However, the link between these three notions and conceptual metaphor is not very clear. So first, these classical notions need to be integrated into modern metaphor theory.

\section{Aristotle's View of Metaphor: Not a Fallacy After All}

The role of Aristotle in modern metaphor theory has mainly been the part of the father of metaphor, which, due to new insights, is now considered out-of-date. At least this is the way in which George Lakoff and Mark Johnson referred to Aristotle in the afterword of their highly influential Metaphors We Live By, writing: "There are four major historical barriers to understanding the nature of metaphorical thought and its profundity, and these amount to four false views of metaphor. In the Western tradition, they all go back at least as far as Aristotle" (2003, p. 244). Likewise, other important conceptual metaphor theorists such as Andrew Ortony (1993, p. 3) and Zoltán Kövecses (2002, p. viii) have disassociated themselves from Aristotle, as did - much earlier - I.A. Richards and Max Black, the founders of the interaction theory on metaphor in which metaphor is treated as active language use (Black, 1954, p. 284; Richards, 1936, p. 89).

This out-of-date stamp, however, has been more a matter of framing than anything else. During the last few decades, academics have convincingly shown that the supposed 
fallacies of Aristotle are based on misreading, and that ancient and modern metaphor theories are not opposed, but rather in many ways complementary (Eco, 1983; Kirby, 1997; Mahon, 1999; Nussbaum \& Putnam, 1992; Ricoeur, 2003). New interpretations of the Rhetoric and the Poetics support the insight that their traditional interpretation has been narrowed during the centuries. In fact, Aristotle did recognize the abundant use of metaphor in normal language, but the focus of the Rhetoric and the Poetics is restricted to the rhetorical and poetic production of metaphor. While these specific uses also involve cognitive processes such as learning and the creation of new meaning (Eco, 1983; Mahon, 1999; Ricoeur, 2003), there is more to learn about Aristotle's ideas on metaphor in normal language and thought in other works. By comparing Aristotle's ideas on language (in On Interpretation) with the passages Aristotle wrote on metaphor, John Kirby made it plausible to argue that Aristotle endorsed what now would be called a "semiotic view on metaphor," which would clearly assign a cognitive function to the phenomenon (Kirby, 1997, p. 535). Furthermore, Martha Nussbaum and Hillary Putnam (1992) showed by examining On the Soul that Aristotle's so-called "separation of body and mind" is based on a misreading as well. This separation forms the essence of a supposed fundamental difference between modern and classical metaphor theory, but Nussbaum and Putnam (1992) show that Aristotle was not so much concerned with the question of the body-mind relation, but rather with the question of identity: what makes a tree a tree and a human a human, even if they change forms. It is only in relation to this question that Aristotle puts form above matter, mind above body (for example, in stating that the soul is what distinguishes a living human being from a corpse), not in any other. Apart from this, Aristotle's view on the soul is in fact very bodily: "The soul is not an 'it' housed in a body, but a functional structure in and of matter" (1992, I. 94I). Additionally, Nussbaum (1996) shows that (bodily) emotions have an important cognitive function in Aristotle's work: they become a way of "knowing" that something is important or true (Nussbaum, 1996, p. 309). So, the modern idea of bodily thought fits quite well within Aristotle's ideas after all.

Of course, there is a substantial distance between Aristotle and modern metaphor theory, but the above readings of Aristotle's ideas on language, thought, and metaphor justify the conclusion that there is no major contradiction between classical and modern views of metaphor. The two are concerned with different aspects of the phenomenon, but that does not make them incompatible. To fully appreciate Aristotle's view on metaphor, however, it is important to understand Aristotle's work as an answer to questions that were urgent in 
400 BC. Since there is no such thing as a timeless idea, as the philosopher Quentin Skinner (1969) has argued, the modern reader has to be careful, as the theory should be understood in the context of ancient Greece.

\section{Aristotle's Metaphor as an Answer to Flattery and Deceit}

An important clue to Aristotle's vision of metaphor can be discerned when he states in the Rhetoric that metaphors are abundantly used "by everybody in conversation" (Rhet I 404b35) ${ }^{27}$ : it shows that Aristotle differentiates between multiple dimensions of metaphor usage, and it is the purpose for which a metaphor is used that makes the difference. If the purpose is normal conversation, everybody is capable of producing metaphors. But when it comes to a rhetorical purpose, "metaphors must be drawn from things that are related to the original thing, and yet not obviously so related - just as in philosophy also, an acute mind will perceive resemblances even in things far apart" (Rhet I4I2a I0-12). To see similarities in things that are different, a mind of the same caliber as a philosopher is required, with insight into logical relations and the capability of making syllogisms (a strict form of logical thinking). For sure, this is a different requirement than for the production of metaphors in conversation, of which everybody is capable. Metaphors used poetically or rhetorically demand a thoughtful mind, and although the two uses have much in common (c.f. Rhet I404b28), they differ substantially in purpose. Where the purpose in the Poetics is defined as "catharsis" (the purification and purgation of emotions), in the Rhetoric the purpose is "an action-guiding decision” (c.f. Oksenberg Rorty, 1996, p. 2I).

Aristotle did not consider every rhetorical use of metaphors to be positive. This was a reaction to a rhetorical practice in ancient Greece in which rhetoric was purely used as a weapon in debate, and was thought to have overwhelming power (e.g., Ricoeur, 2003, p. 10). Aristotle rejected this kind of rhetorical practice, and tried to distinguish real persuasion from the sophistic practice of flattery, threat, and deceit. Since rhetoric was used in assemblies and courts, there was, according to Aristotle, no scientific proof needed of the truth, as in science; because politics had to do with the future, one could never be certain of the truth. However, it was possible to discover the best possible solution through

\footnotetext{
27 If not mentioned otherwise, references to Aristotle are to the revised Oxford translation (Aristotle, trans. 1984).
} 
deliberation. Rhetoric should therefore lead to the most reasonable and probable decision. Because of this reasonable fundament, there is (unlike in later rhetorical theory) an important linkage of rhetoric with logic (Oksenberg Rorty, 1996, p. I,8; Ricoeur, 2003, p. 10). It is significant here that the first sentence of the Rhetoric states that it is the counterpart of Dialectic (Aristotle's logical treatises) (Rhetl354al). Also, the definition of metaphor in the Poetics (of which the latter part is omitted in most citations) should be understood in this light. It shows clearly the subordination of metaphor to Aristotle's logical categories: "Metaphor consists in giving the thing a name that belongs to something else; the transference either from genus to species, or from species to genus, or from species to species, or on ground of analogy" (Poet |457b7-9).

So, rhetoric should result in real persuasion based on philosophy and logic, and not on sophistic flattery and deceit. Aristotle saw different means to guarantee this. The first one is that logos - the plain argument-must be the leading principle. Certainly, also emotions (pathos) and the character of the speaker (ethos) are important, but only in order to help the audience to be persuaded of the reasonable and probable (e.g. Carey, 1996, p. 399). It is only because the audience is affected by other means than the logos that Aristotle needs the rhetorical means of ethos and pathos (Rhet I404a). Nevertheless, a rhetorician should always ensure that there is valid reasoning behind an emotional figure when he chooses to use it; otherwise it would not be genuine persuasion but deceit.

Unfortunately, logos cannot always be trusted. Reasoning and arguments, as well as emotions, can be fallacious. Arguments should be based on real "enthymemes" (the rhetorical shorter variant of a syllogism, the procedure for logical thought), but sometimes they are not (Rhet I400b34). This happens, for instance, when something is presented as a cause when it is not, or when what counts for the parts is presented as counting for the whole as well, which is not necessarily true (Rhet I40 la24-b30). This kind of deceit can only be revealed by genuine reasoning and logic.

In short, in the frame of a reasonable rhetoric, as opposed to a sophistic and manipulative one, it makes sense that the use of metaphor was restricted to a rational use. This restriction did not mean that Aristotle thought that this was the only way a metaphor could be produced. On the contrary; sophistic rhetoric was full of wrong emotional metaphors, and that is why these restrictions were necessary. 


\section{Aristotle's Metaphor in Relation to Imagination and Thought}

To understand the function of metaphor in Aristotle's work better, it is helpful to look at his concept of phantasia (imagination). Although the production of good (i.e. rational) rhetorical metaphors was primarily and necessarily a rational process, the appreciation of the metaphor by the audience had much to do with phantasia, and this had to be anticipated during the production of the metaphor (Oksenberg Rorty, 1996, p. 23).

Looking more closely at the concept of phantasia or imagination in On the soul (434a6-7), Aristotle distinguished two types of imagination: there is "sensitive imagination" which is present in all animals, and "calculative imagination" 28 which only animals that are calculative possess, i.e. humans (c.f. Frede, 1992; Oksenberg Rorty, 1996, p. 19). Where sensitive imagination refers to unconscious imaginative thought as in dreams or when drunk, calculative imagination involves some sort of rational activity resulting in a strategy, such as the combination of images and a goal. For example, when you speak of "a golden dawn" it makes you want to get out of bed early. Although the sensitive type of imagination also contains a desire, it is more instinctive, like appetite or lust (Oksenberg Rorty, 1996, Pp. 1923) and involves no calculative strategy.

So, the production of metaphor had to anticipate the fact that the audience comprehends the metaphor in an imaginative, emotional way. A rhetorician could expect to evoke one of two types of imagination in the audience: either sensitive or calculative, both of which could be false or good. Not all emotions were considered to be right, and neither were all calculations. Only philosophy and genuine reasoning could assess whether the evoked emotion would lead to a good decision and action. It was nevertheless always uncertain whether the audience was actually going to experience the anticipated emotion; this would depend on the belief of the audience that the metaphor was telling the truth. According to Aristotle, images do not automatically come with emotions, as the emotions come from the belief that the image is (or could be) real (Nussbaum, 1996, p. 208); watching a movie with a murderer in it is not really frightening, only the belief that this murderer is

\footnotetext{
28 Although the Oxford edition (1984) uses the translation 'deliberative imagination' I prefer Oksenberg Rortie's translation as 'calculative imagination' (1996, p. 20). In Aristotle's writings on deliberation, the word 'deliberative' is often used with the meaning of 'reasonable' and 'non-sophistic'. This has nothing to do with calculative imagination and using the term here would therefore be confusing.
} 
actually somewhere in your house is. This would mean that only persuasive images (that are believed to be true) would come with emotions. In this light, it is clear that an orator should conceal his calculative strategy: if the public knew that there was a rhetorical strategy behind an apparent spontaneous speech, this would diminish the belief in the truth and the persuasive power of metaphor. In a similar way, the strategia (the military leadership in ancient Greece) used metaphors to sell their military plans to the people (Rhet I $4 \mid$ Ia), but they never revealed their exact military strategy. This had to stay concealed in order to be effective.

\section{Where Aristotle Meets Conceptual Metaphor Analysis}

How does this all relate to conceptual metaphor analysis? In order to draw an accurate picture, I will start with Lakoff's most recent description of conceptual metaphor (2008). He describes it as the simultaneous activation of two neural circuits in the brain. These neural circuits (also known as mental spaces) become connected with each other through simultaneous activation: "what fires together, wires together." The result is a "blended mental space" where two or more concepts are directly linked through neural binding, and as a result a metaphorical, embodied meaning is created. For example, when a child gets a warning that fire is dangerous, in their mind the two concepts become linked, along with the feeling that they experience. The next time the child hears the word fire, they will automatically also think of danger and feel anxiety. This metaphor concept is represented in Figure 7.I, in the circle labeled CMT (Conceptual Metaphor Theory), situated in the upper rectangle that represents thought.

Although Aristotle did not of course speak of neural circuits and embodied thought, his idea of phantasia (imagination) resembles very much the concept of a mental space. Aristotle calls it "a motion that does not happen without sense-perception but comes to be as the result of the activity of sense-perception" (428b I I-I5, trans. Frede, I992, I. 4334). This means that phantasia is an action or a process, like a mental space in conceptual metaphor theory. It establishes the connection between the intellect and its sensible objects (c.f. Frede, 1992, I. 4424), and, most importantly, "without phantasia there can be no thought" (427b I6, trans. Frede, 1992, I. 432I). In the figure, imagination is therefore placed next to the CMT-blended space in the domain of thought. Since Aristotle acknowledges two different types of imagination, it follows that there should be also two different types of 
mental space and, consequently, two types of conceptual metaphor: a sensitive type and a calculative type. This is also portrayed in Figure 7.I.

The division between sensitive and calculative imagination calls to mind the distinction between metaphors in the discussion on deliberate or purposeful use of metaphor referred to earlier (c.f. Charteris-Black, 20I2; Gibbs, Jr., 20I I; Steen, 2008). The sensitive type resembles non-purposeful or non-deliberate metaphor, as there is a direct referral to the senses without any deliberate or purposeful calculation, as in dreams or when drunk. Besides, sensitive imagination encompasses non-metaphorical concepts, as do mental spaces (Lakoff, 2008, p. 30). The calculative type of imagination resembles purposeful conceptual metaphors; it requires a calculated combination of imaginations and a rational activity, such as the combination of two images, which results in a purposeful goal or desire, a calculated strategy. Where sensitive imagination results in un-purposeful metaphors in language (left lower rectangle), calculative imagination results in purposeful communication (right lower rectangle).

As shown in the figure, there are different types of purposeful metaphor, such as poetical and rhetorical metaphors. When it comes to rhetorical metaphors, Aristotle approved only one subtype: the metaphor that is subservient to rational judgment (the right lower circle), in contrast with sophistic metaphors in which emotion is unrestricted (the left lower circle). To assess this, the blended space (in thought) has to be expanded with an extra dimension: deliberation. Deliberation evaluates the imagination according to rational standards and judges whether there is a rational argument that supports its desire or plan. In Figure 7.I, deliberation and rational thought are also placed in the domain of thought. The arrow that starts here indicates the impact of rational thought on calculative imagination and metaphor. Since sensitive imagination also has impact on calculative imagination, there is another arrow going from sensitive imagination (with its un-purposeful metaphors) to calculative imagination (with its purposeful metaphors). 


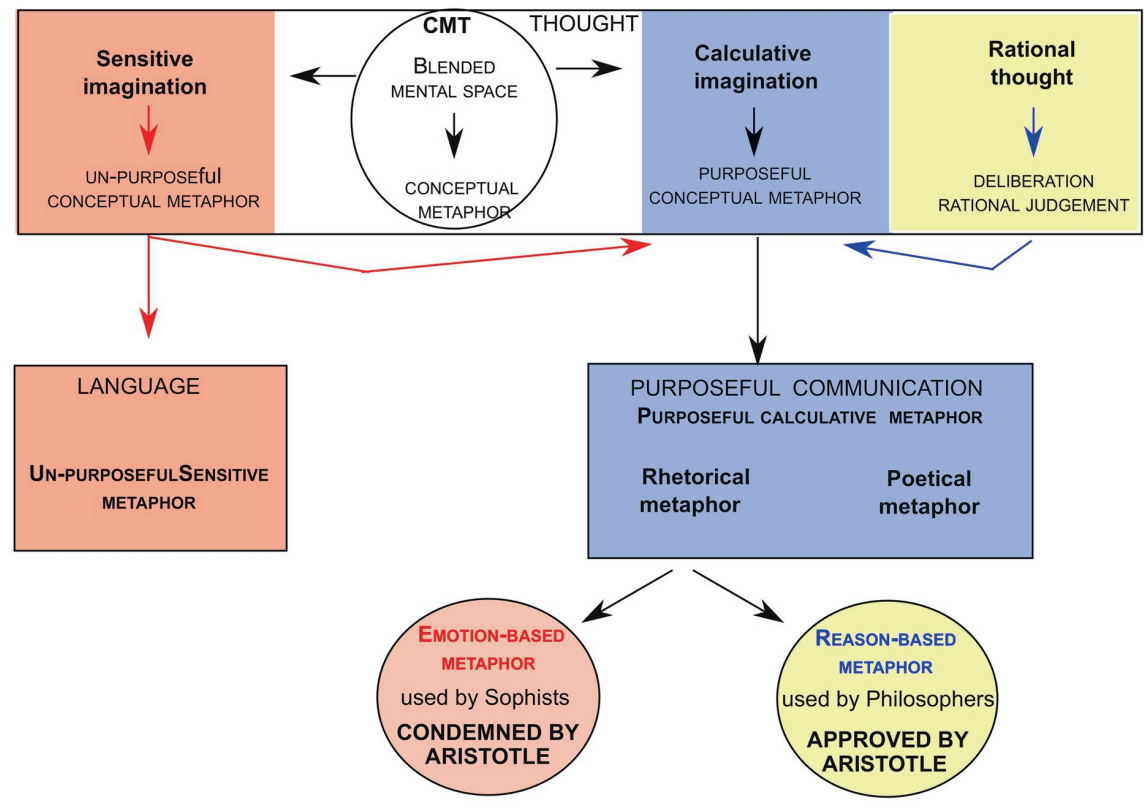

Figure 7.I Where Aristotle meets Conceptual Metaphor Theory (CMT).

Aristotle would strongly disapprove of the kind of metaphors in which sensitive imagination is foremost, as he did with other Sophistic language. In today's political philosophy this normative aspect of Aristotle is disputed. Not only public reason must have its part in democracy, but also partiality, passion and even prejudice, for which rhetoric would offer room (Fontana, Nederman, \& Remer, 2004; Garsten, 2006). Still, the question as to whether the metaphor has a rationale stays relevant in the context of political style. As mentioned before, politics is determined by the taste and style of politicians, in which voters can recognize themselves - or not (c.f. Ankersmit, 1996). A deliberative style, which was supported by Aristotle, would address a different public than a more sophistic style. In this context it would be preferable to replace the value-loaded terms that Aristotle used (deliberative vs. sophistic) with more neutral equivalents, such as reason-based vs. emotionbased metaphor. 


\section{Application in Political Metaphor Analysis}

Now that I have outlined where classical and modern metaphor theories meet, I will use this meeting point for a combined application of the two theories in political metaphor analysis. In doing this, I have to consider the fact that it was not Aristotle's purpose to describe all possible usages of metaphors: he only wrote extensively about metaphor in which the logos (the rational argumentation) was foremost because that was the metaphor type he wanted to teach to his students. More indirectly he wrote about metaphors in which the pathos (the emotional persuasion) is predominant, in the slipstream of his attack on Sophistic language. However, there is a third type of metaphor that Aristotle implied; the metaphor in which the ethos is privileged.

Ethos is described as affirming trust in the sender, and along with text elements that depict the sender of a political message as a wise or good person, this purpose is directly linked with rhetorical communication itself; a rhetorical strategy has to be concealed to be effective. A sender would not seem reliable if it were obvious that he had a purposeful rhetorical strategy and the strategic purpose should therefore stay unmentioned and invisible - like the military strategies mentioned earlier. To cover-up the strategic purpose, people are led to believe that there is an emotional or rational purpose for the persuasion in question. However, this does not mean that there are no strategic metaphors besides the ones that show the trustworthiness of the speaker. Concealment is only needed with your own strategic communication purpose, while revelation of the strategic purpose of your opponent (or the suggestion of a strategic purpose) is the best way to torpedo that strategy.

Summarized (as portrayed in Figure 7.2), it is possible to distinguish three types of purposeful political metaphors: reason-based, strategy-based and emotion-based. Although all metaphors will to some extent serve all three purposes, there is in most metaphors one purpose most visible to the public. The upper part of the figure shows the three domains of thought that Aristotle distinguished: sensitive imagination, calculative imagination, and rational judgment (upper ovals in the figure). Calculative imagination can lead to purposeful political metaphor (middle oval), but is influenced by both sensitive imagination (in which emotions are leading), and by argumentation (in which reason is leading). If emotions (pathos) are the main visible purpose in the political metaphor, it can be characterized as an emotion-based political metaphor; if deliberation (logos) is the most noticeable purpose, it is a reason-based political metaphor; and if revealing or concealing of strategy (ethos) is the 
predominant purpose to the public, it is a strategy-based political metaphor (lower circles). With these three styles, the link between conceptual metaphor and Aristotle's means of persuasion (logos, ethos, and pathos) becomes clear (see Figure 7.2). I will illustrate this with some examples.

First, however, it is important to clarify that there are two levels concerned here, which might be confusing: the level of purposeful use of conceptual metaphors and the level of the classical rhetorical figures. In the latter, a metaphor exists along with figures such as allusions, similes, metonyms, and so on. Where classical rhetoric makes a clear distinction between these figures of speech, on the conceptual level a metaphor is much more broadly defined; something is a metaphor if it expresses a metaphorical relation between two cognitive domains, if there is a sort of "analogical thinking" (c.f. Dedre Gentner, Bowdle, Wolff, \& Boronat, 200I, Pp. 199-200, 243). Although CMT does make a distinction between metaphor and metonymy, this distinction is at the most a relative matter, as metonymy is often the base of a conceptual metaphor (Dirven, 2002). Generally spoken, a conceptual metaphor can take the form of a classical metaphor, but also the form of a metonymy, a simile, an allusion, or another figure of speech. All these classical figures can therefore also be characterized as purposeful metaphors (either emotion-, strategy- or reason-based), but only if they express an analogical thought.

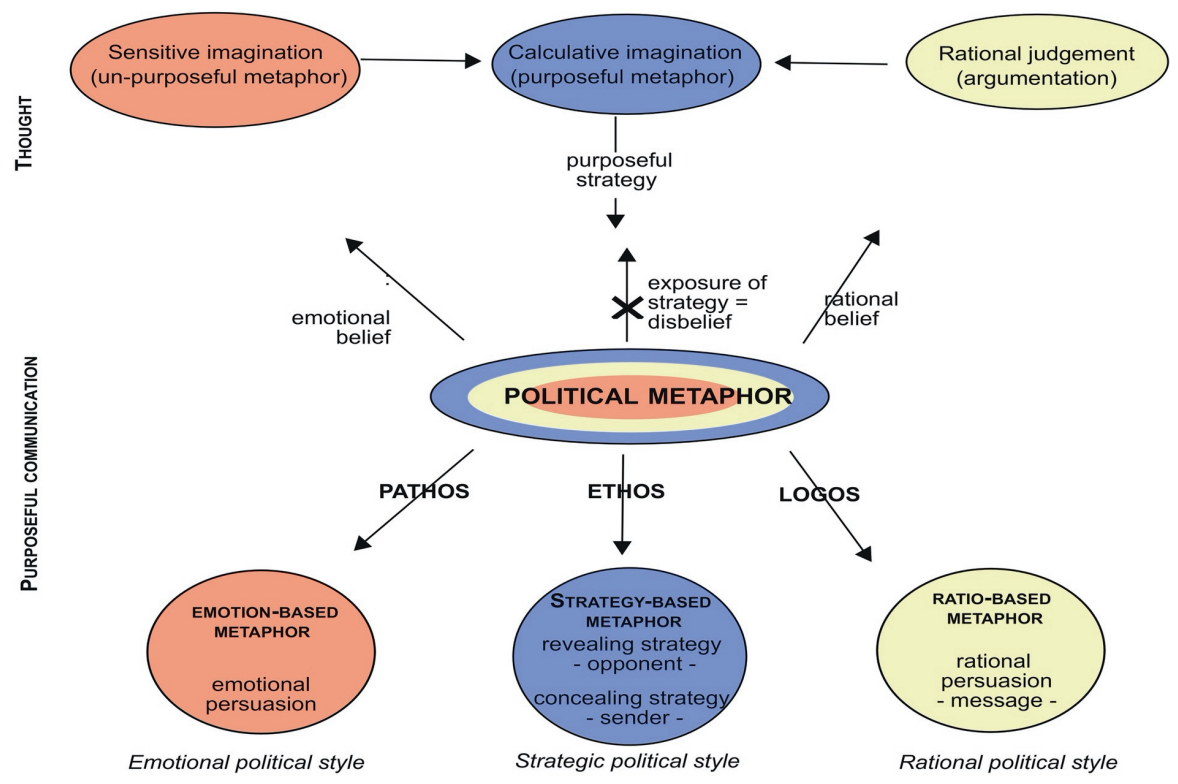

Figure 7.2 Three purposes for political metaphor. 


\section{I Emotion-based metaphor.}

A good example of an emotion-based metaphor can be found in the allusion (a figure of speech in which there is an evocation of another context) to the Kristallnacht for the window-breaking by members of the Occupy movement. This allusion provoked a fierce debate in the US media at the beginning of 2014. It started with a letter by Tom Perkins published in The Wall Street Journal, in which he "would call attention to the parallels of Nazi Germany to its war on its 'one percent,' namely its Jews, to the progressive war on the American one percent, namely the 'rich"' (Perkins, 20I4). The conceptual metaphor behind this simile is PROGRESSIVES ARE NAZIS. This is an emotion-based purposeful metaphor and it is primarily meant as an expression of Tom Perkins' feeling of being threatened, as Perkins explained later when he made an apology on Bloomberg television:

I used the word because during the occupy of San Francisco by the Occupy Wall Street Crowd, they broke the windows in the Wells Fargo Bank, they marched up to our automobile strip on Van Ness Avenue and broke all the windows on all the luxury car dealerships, and I saw that, I remembered that, the police just stood by frozen, and I thought, well, this is how Kristallnacht began, so that word was in my mind. (Kopan, 2014)

That Perkins made an apology for this comparison shows that he had to admit it did not hold against rational refutation, as pointed out in The Economist: "Nazis wanted to exterminate Jews and progressives want the richest Americans to pay slightly more taxes than they are paying now. That may be a good or a bad idea, but it is not genocide" (Night of broken metaphors, 20I4). Although there are apparent similarities, such as broken windows and violence against a minority, these ostensible parallels do not justify other parts of the analogy. Therefore, the major part of the public assessed this conceptual metaphor not as reason-based (the argumentation behind it is not probable but rather highly controversial) but primarily emotion-based. Normally the debate about this kind of emotion-based use of metaphor stays focussed on the question of whether the analogy is appropriate or not. The focus on the three metaphor types makes it possible to see beyond this level and look at other purposes: besides the rational purpose of making a reasonable comparison, which did not turn out so well, the metaphor is a purposeful expression of an emotion, as Mr. Perkins 
genuinely felt threatened. Furthermore, it is important to be aware that there are also strategic purposes involved. To get an insight into these strategic purposes, it is necessary to consider the context; in this case, it is meaningful that Mr. Perkins has a direct interest in the political debate on raising taxes for the rich, as he turns out to be a billionaire himself.

\subsection{Strategy-based metaphor.}

A good example of a strategy-based metaphor comes from the Dutch populist Geert Wilders, who has complained that EU-politicians "fill their pockets with high salaries and perks" (Wilders, 2012). The metaphor is a literal translation of a Dutch proverb, in which pocket filling means that someone is taking money in an illegitimate way (the proper translation would be lining their own pockets). The image is clear: a pocket is a private container, filled with money, in the same way that a bank account is often depicted as a container. In other words: Wilders suggests that other politicians are not involved in European politics for the greater good, but for their own gain, and that the EU only exists for the benefit of the politicians themselves. In this way, he does not need to combat the arguments of his opponents, he simply dismisses their strategy, and at the same time he is making his main political point that the EU integration project should be terminated. So in this example, the strategic metaphor enhances Wilders' strategic political purpose. There are also emotional and rational aspects to this metaphor, as it rouses the emotions against the politicians in question and it is underpinned by salary figures.

\subsection{Reason-based metaphor.}

An example of a reason-based metaphor is present in a comparison made in The New York Times, in an article on Russian President Vladimir Putin's policy of basing his economy on oil and gas income: “The Stone Age didn't end because we ran out of stones. It ended because we invented bronze tools, which were more productive" (Friedman, 20I4). The analogy on which this comparison was based showed that Putin was betting on the wrong horse in basing the Russian economy mainly on the export of oil and gas. Recent developments in renewable energy are remarkable, and it is to be expected that solar and wind energy will soon become not only better for the environment, but more efficient than hydrocarbon energy sources as well. The purpose of this comparison is - at least partly - rational 
persuasion, as it tries to explain a complicated economic subject in a compelling way. Although the analogy is not valid in all respects (for example, the invention of bronze implements was not motivated by the threat of a future lack of stones), it is still justified because it is proportional and explains clearly the argument at stake. But, notwithstanding its rational character, there is also an emotional and strategic purpose, as Putin is framed as being stuck in the Stone Age. For a broader perspective on this, again the context must be considered, in this case Friedman's background. If he had ties with Ukraine or was a stakeholder in competing oilfields, he would have a strategic interest in evoking negative emotions towards Putin. But since Friedman is a Pulitzer Prize-winning independent journalist, and seems not to have a direct interest in the matter, his trustworthiness is strong and the visible strategic purpose of this metaphor is relatively small. Russian readers, on the other hand, might say that he does have an interest here, because the newspaper in which he was published is American and therefore against Putin, which would make the persuasive basis as a whole less convincing for the Russian reader.

\subsection{Interaction between purposes and metaphors.}

These examples illustrate that the three purposes of metaphors are in direct interaction with each other. There are a few remarks to be made here. First, the purposes are not mutually exclusive. For example, a strong rational purpose does not imply that the emotional purpose is automatically weak. For instance, in this quote: "Putin's legitimacy depends on keeping Russia and the world addicted to oil and gas" (Friedman, 2014). The underlying conceptual metaphor OIL USE IS ADDICTION contains a strong emotional value - an addiction is bad and can even be fatal - but here, most of the audience will assess it as a reason-based metaphor because it is broadly accepted as true that we cannot do without oil despite the fact that it is bad for the environment. Nevertheless, this does not make the word addiction less emotional. Additionally, the use of the word keeping depicts Putin as a drug dealer, which reveals that the metaphor also has a strong emotional purpose with regard to Putin; as the drug-dealing element is an addition to the metaphor of being addicted, it is not subservient to the rational purpose. So, the two different purposes may influence each other, but they are not interdependent.

Secondly, an analyst should be aware of the history of a metaphor. For example, the OIL-AGE IS STONE-AGE metaphor had been coined long before Friedman employed it, by other 
senders and for other purposes. Sheikh Zaki Yamani, the Saudi oil minister during the Arab oil boycott of the United States, had already used it in the seventies and it has been picked up by others since then. Knowing the background of this sender enhances the rational persuasive power of the metaphor; if there is one person who has no strategic interest at all in an end to the Oil age, it is the Saudi oil minister, so, the reasoning is, he must have had other (in this case rational) purposes in using this metaphor (c.f. "The end of the oil age," 2003). So, metaphor purposes are closely connected to the context and to earlier use of the metaphor. In the analysis of an isolated political speech, it is almost never possible to give consideration to these contextual influences. It is therefore important to analyze political utterances in a wider political context.

As shown in the examples, it is possible to distinguish the purposes that are behind the use of a political metaphor by examining the text within its context, paying attention to conceptual metaphor, rhetorical figures, and the wider political context. Furthermore, it is possible to distinguish the rhetorical style of a politician by analyzing a number of their texts: if most of the metaphors they employ are subservient to rational argument and are used to make an argument more vivid, a politician deploys a rational rhetorical style; if most metaphors give full space to the expression of an emotion, even if there is a conflict with the rational argument, an emotional style is dominant; and, if metaphors are primarily used for the concealment of the political strategy of the speaker or the revelation of the strategy of the opponent, a politician is said to have a strategic rhetorical style. This distinction is important for further political analysis, to assess what the role of rhetorical style is in political processes.

\section{Contribution to Discussion}

Since this chapter was focused on metaphor usage for building a political identity and style, it does not cover all political metaphor purposes. Other purposes, such as winning elections, seeking political endorsement for a position, or calling people to action, are not considered; however, it would be possible to examine whether the rhetorical style of the same politician stays constant or alters when their political purposes change.

In this chapter, conceptual metaphor analysis is extended with the aspect of deliberation or rational judgment. This extension validates the central place of deliberation in politics and would be justified for this reason alone. A counterargument would be that 
according to CMT there is no such thing as pure rational deliberation, since conceptual metaphors play their part everywhere in language and thought. According to Lakoff, persuasion takes place at the unconscious, metaphorical level (Lakoff, 2004, p. 17). But this is not a black and white issue. Accepting the notion that all language and thought are loaded with values and emotions does not mean that the rational part of a metaphor cannot make any difference. It is still possible that, although an exclusively rational thought does not exist, one utterance is more rational than another and that this has a persuasive effect. Rational arguments work together with emotional language in the ingenious interplay that constitutes persuasion.

Another new element in this chapter is the distinction between emotion-based, reason-based, and strategy-based purposeful metaphors. This triad is directly linked with Aristotle's pathos, logos, and ethos, which offers the advantage of a coherent combination of modern and classical metaphor theory. Furthermore, the triad sheds new light on some assumptions in former metaphor research; for example, the assumption that the presence of more metaphors in a text would automatically mean that this text is also more subjective (e.g., Postma, 20I I, p. 36). The distinction of the three types of rhetorical metaphor shows that this is not necessarily true, as a reason-based metaphor is in principle as objective as a rational argument (although the reason-based metaphor is likely more emotional than the argument, but that is a different matter). To really see if a text is more subjective, additional analysis would be needed; only more emotion-based metaphors would indicate that a text is more subjective, since there is no rational inter-subjective argument behind this type of metaphor.

This chapter shows furthermore that the purpose of metaphors is too tied up with the context to be understood separately from it. This context encompasses both time (earlier use) and political arena (reaction at the political situation) and both should be taken into account in political metaphor analysis. Although it will not be easy to reveal strategic purposes of a sender, which, as has been shown, are by nature concealed, it is not impossible; it is not necessary to look into the senders' head, as the purposes should be somewhere in the political discourse (c.f. Charteris-Black, 20I2, p. 4). However, automated computer-led data analyses are not suitable for this kind of metaphor research, since they cannot reckon with the context. As a helping hand, search engines such as Google can be effective, for example in the detection of prior uses of a metaphor. Also large data corpora which allow access to the transcripts of political debates, are interesting research sources. 
However, although computers can be helpful, in the end it always comes down to the analytical skill of the analyst.

\section{Conclusion}

The return to Aristotle's questions has been illuminating in the discussion on purposeful metaphor. Aristotle offers a useful perspective on purposeful rhetorical style, as he was primarily concerned with the question of the difference between rational and emotional persuasion, between Sophistic and deliberative use of language. His theory, combined with conceptual metaphor theory, has led in this chapter to the distinction between emotionbased, strategy-based, and reason-based purposeful metaphors. This division is vital for political metaphor analysis, as it gives an insight into the underlying purposes of a metaphor as well as the role metaphors play in politics. In addition, it offers a way to determine the rhetorical style of politicians by analyzing the metaphors they use, which is important for the further clarification of political processes. And finally, perhaps not the principal goal of this chapter but nevertheless noteworthy; this chapter restores to Aristotle the credit he deserves; that of the father of metaphor who is - like most fathers - maybe a bit oldfashioned, but definitely not out-of-date. 


\section{8 \\ The People as Heroes, Animals, or the Country?}

\section{Metaphor in Populist and Non-Populist Political Discourse}
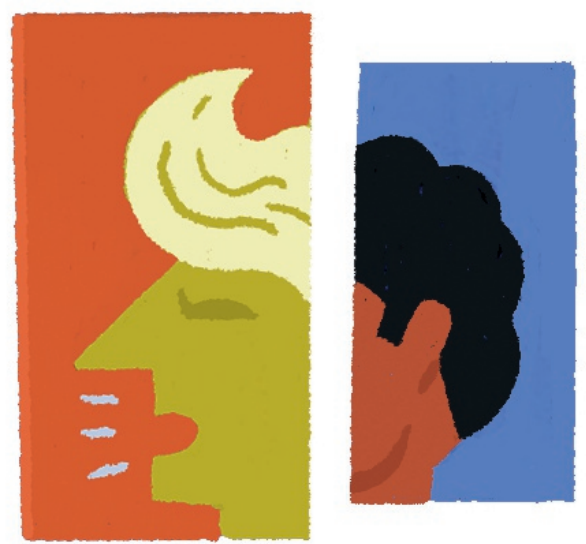

This chapter is a minor revision of: Schoor, C. (2020). The people as heroes, animals, or the country? Metaphor in populist and non-populist political discourse. In: Metaphor in political conflict. Populism and discourse. C. Llamas Saíz and Ruth Breeze. (Eds.) Pamplona, SP: EUNSA. PP. 83-I I0. Parts of this chapter have been presented at the conference: In the name of the people: representing the people in twenty-first century politics, November 22-24, 2018 , University of Navarra, Pamplona, Spain. 
For the politician should resemble the man

who, as we have often seen in Africa,

seated on a huge and unsightly elephant,

can guide and rule the monster,

and turn him whichever way he likes

by a mere sign, without any violence.

Cicero, De Re Publica, book II.

\section{Abstract}

This chapter presents a comparative metaphor analysis of three politicians' speeches with a different political style, in order to clarify differences in the metaphors by relating them to the political style of the speeches. The speeches are selected from a set of US, UK, and Dutch political speeches, and have already been analyzed in terms of populism, elitism, pluralism, or a mix of these (see Chapters 5 and 6). The three selected speeches typically express one style in full; populist - Geert Wilders (NL); elitist - Boris Johnson (UK); and pluralist - Barack Obama (US). The analysis focuses on metaphors connected with key concepts of political style, such as the people,' the (political) elite, government, and politics. Besides thematic differences - for instance, the war-metaphor is applied differently in the populist speech - the analysis shows a different accent in the main purpose of the metaphors.

\section{Introduction}

From Aristotle to conceptual metaphor theory, the consensus is that metaphor impacts substantially on political communication (e.g., Aristotle, trans. 1984; Charteris-Black, 20I I; Musolff, 2017). As populism is on the rise as a global phenomenon (e.g., Norris \& Inglehart, 2019), and is often characterized as a political style (Canovan, 2002; Moffitt, 2016), the question arises how metaphors contribute to a populist political style. Do populist politicians employ metaphors differently from non-populist politicians? If so, does this have rhetorical advances, or are there other reasons for a populist usage of metaphor? For instance, populism is often associated with emotional politics, which might be reflected in the purpose with which metaphors are employed. 
These questions can be explored by comparing the metaphors used in speeches of populist politicians with metaphors of politicians who are not considered populists. This chapter presents such an analysis on the limited scale of three speeches. An in-depth analysis of one populist, one elitist, and one pluralist speech demonstrates how these three political styles are expressed in different metaphors. Subsequently, by comparing the metaphors used in the three speeches for the same elements, boundaries of metaphor usage become visible. Besides, this chapter looks for patterns in the function of these metaphors in the speeches, to identify if there is also a specific purpose for those metaphors.

The political speeches analyzed in this chapter have already been assessed on their political style in previous research, in which speeches of politicians originating from three countries were compared: the US, the UK, and the Netherlands (see chapters 5 and 6). The speech analysis-method used differentiates between populist, pluralist, and elitist political styles, as explained in the next section. The selected political speeches typically express one of these three styles in full. The populist discourse analyzed is from two speeches by the Dutch politician Geert Wilders. The elitist speech was delivered by the British politician Boris Johnson, whereas Barack Obama gave the pluralist speech. All speeches date from 2016 and 2017.

Section 2 briefly describes the method used to define the political style of the speeches, together with the theoretical background concerning political style and populism. Section 3 explains the methods used for metaphor identification and analysis. The actual metaphor analyses are portrayed in sections 4, 5, and 6. In section 7, the three metaphor practices are compared, leading to the general conclusion and discussion.

\section{Political Style and Populism Theory}

Political style can be defined as a stylized political performance on the political front stage, purposed to fill the "aesthetic referential gap" with a political identity (see chapters 2 and 3 ). As argued by Ankersmit, politicians are never identical to the people that they represent, for which reason there is always an aesthetic referential gap between the voter and the representative (Ankersmit, 1996; Pels, 2003a). In order to connect with their own group of people, politicians stylize their performance into a unique political identity, so that people can recognize this politician as their representative. This political identity is not principally different from any other person's, as identities are never fixed and stable but dependent on 
the people and spaces with which they are surrounded (Butler, 1988; Goffman, 1956). However, because politicians' professional survival depends on their popularity, their style is essential for their political life. A political style can be dissected into three dimensions: politicians express their ideas (ideational dimension), they have to connect with similar people (social dimension), and persuade people that do not think alike yet (presentational dimension) (see Chapter 3).

To be able to assess the political style of politicians comparably, political style has been split up into five focus elements, based on the position that politicians take on the political front stage. On this stage, politicians compete with each other while being observed by an audience. The political stage consists of five discursive elements on which politicians can express their political identity as unique, apart from their political standpoints: I The people, 2 The political elite, 3 Democracy/government, 4 Politics, and 5 The political context (see Chapter 3). For instance, politicians can speak about the people or the elite (Elements I and 2) as a homogeneous or a heterogeneous group, as good or bad, competent or incompetent to govern. They can present the government or democracy (Element 3) as corrupt or as good, fake or respectable. Politicians can speak about politics (Element 4) as a fight, or as cooperation. Also, they can proclaim that the political context as a whole (Element 5) is in crisis or in progress.

The metaphor analysis in this chapter focuses on these five political style elements. This links metaphor use directly to political style and can shed light on the role that metaphor plays in stylized politics, such as populism. Populism does not stand on its own; it directly relates to pluralism and elitism (e.g., Mudde, 20I7; J.-W. Müller, 20I6). A semiotic analysis, described in Chapter 4, more precisely explores the relationship between populism, elitism, and pluralism. This analysis shows that populism, elitism, and pluralism share one grammar of meaning. In this grammar, the common features of two of the three concepts always linearly contradict the third, as follows:

- Pluralism views the people as a heterogeneous group, whereas populism and elitism see the people as non-heterogeneous (homogeneous or equalized as one through populism). This is a cognitive matter (ideational dimension).

- In elitism, politicians are part of the elite and want power for the elite, whereas populism and pluralism claim power for the people and politicians are part of the people. This is a matter of group relations (social dimension). 
- In populism, political leaders posit a (quasi) unmediated relationship with the people; they present themselves as if they are the people, whereas elitist and pluralist politicians present a mediated relationship with the people they represent. This is a rhetorical matter (presentational dimension).

The three-dimensional oppositions can be visualized as a triangular framework, with populism, elitism, and pluralism at the corners and their anti-styles at the opposite sides of the triangle (see Figure 8.I). Three corners and opposite sides visualize the oppositions in the three dimensions.

For a political style analysis, the three-dimensional structure of populism entails that the same text has to be analyzed using three different lenses for the five elements, as the same element can express another style in different dimensions. For instance, a sentence such as "We, as a people, feel betrayed" is mixed populist/pluralist in the social dimension because it speaks of the people as "we." At the same time, it is populist in the presentational dimension because it expresses an (as if) unmediated knowledge of the people. Ideationally it is mixed populist/elitist because it depicts the people as a homogeneous group. Overall, the average of the three is a full populist style. However, most politicians are found to have less consistent styles (see chapters 5 and 6); the three dimensions can be seen as building blocks with which political styles are assembled. In one element, the three dimensions never differ extremely from each other, as the ideational dimension is only knowable through discourse use and social action (the other two dimensions), so they overlap for a large part. However, over the five style elements, they do show variation.

For instance, many (left-wing) populist politicians combine a pluralist view of the people (Element I) with a populist view of the elite (Element 2). Only a few politicians show a full style; many politicians tend to mix two styles (so, populism/elitism, pluralism/elitism, or populism/pluralism). This is visible in Figure 8. I, which shows the overall score of multiple speech analyses. The circles demarcate which of these analyzed speeches are selected for examination on metaphor usage in this chapter; Obama is selected because he had a clearcut pluralist style, Johnson's 2017 speech is selected because it showed a clear-cut elitist style, and Wilders is chosen from other full populists because he was Dutch, which kept the nationalities of the politicians balanced. Although Johnson is often characterized as a populist, the figure shows that his three speeches analyzed all combine elitism with populism (in Chapter 6, a more elaborate explanation of Johnson's elitist-populist style mix). Only his 
2016 Brexit speech is assessed as more populist than elitist; the two other speeches both fall within the full elitist range. This justifies classifying him as an elitist, albeit with populist traits. Johnson's populism can mostly be explained by the Brexit referendum campaign or involves shared features of populism and elitism (namely anti-pluralist features). His 2017 speech is chosen for further analysis because it most clearly had a fully elitist style.

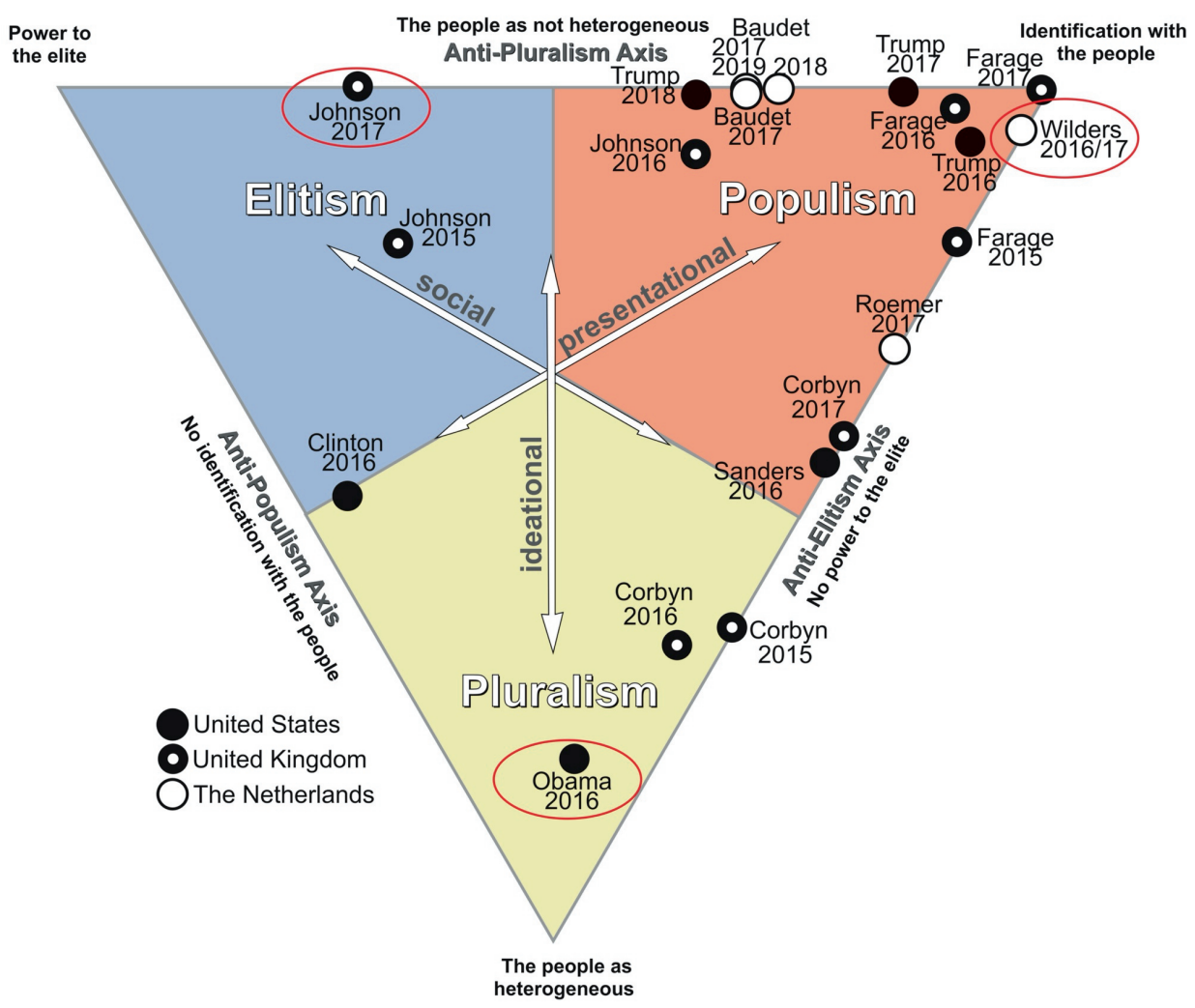

Figure 8.I Twenty speeches (listed in Appendix A) analyzed on political style. The three circled speeches are further analyzed on metaphor usage.

More detailed descriptions of the political style analyses in Figure 8.I are given in chapters 5 and 6. The main focus was on the content of the speeches. The general presentation played a role in this, including metaphors, but without a special focus on these. The metaphor analysis presented in this chapter is performed in addition to the style analysis and solely focused on the metaphors used. 
In the analysis on which Figure 8.I is based, the political style of each politician was relatively defined within its own political context. After having defined multiple political styles originating in different contexts, it becomes feasible to study populism at an inter-contextual level, as the definition of political style is formulated at a higher abstraction level.

Comparisons are only meaningful at this higher abstraction level. For instance, one of Boris Johnson's metaphors for the people is "the lion," which directly relates to the British symbol of the lion for the British nation. This metaphor has the same traditional connotation in the Netherlands because the lion is also a Dutch symbol for the nation, but in the US, this metaphor is less likely to occur in this context, because it does not figure as a national symbol - its equivalent would be an eagle. So, on this level, a comparison is not meaningful. Nevertheless, focusing on political style, the lion is meaningful because it refers to the people depicted as a circus animal that follows the will of the lion tamer. This makes it an elitist metaphor - as a domesticized animal, that is, a metaphor category at another abstractionlevel.

\section{Metaphor Theory}

In Conceptual Metaphor Theory, a metaphor is defined as a "cross-domain mapping," or as the connection that is created between two domains of experience by using one domain to signify the other (Kövecses, 2017; Lakoff, 1993). The two domains are often referred to as the source and target domain; the source-domain is the provider of the metaphorical image that is used for the semiotic structure of the target-domain. Additionally, blending theory highlights that this transmission of meaning is not merely a transmission: in the confrontation of the source and the target domain, a "blended space" is created that generates a new meaning (Dancygier, 2017; Fauconnier \& Turner, 2008). As already suggested by Ricoeur $(1978,2003)$, this new meaning is more than the sum of the meanings of the two domains and encompasses more than language: it involves the whole experience, encompassing thought, emotion, language, as well as physical experiences.

In this conceptual sense, populism, as a political performance, is a metaphorical process in itself: populist politicians metaphorically signify the people; they make the people present in the political realm through metaphorical identification rather than through symbolic representation. The people and the populist leader blend into one conceptual space in which the populist becomes an embodied people, directly speaking for them. Through this 
blend, populists claim to be the only ones that genuinely speak on behalf of the people, as they do not represent them, but are the people. In the construction of this blend, the whole personality of the politician plays a part, as expressed in appearance, attitude, language, register, and dialect. This being said, the following analysis focuses on the specific role of metaphor occurring in language for the construction of the populist blend.

For the use of metaphor in language, the distinction between communicative, linguistic, and conceptual metaphor is relevant (Steen, 2008). The distinction puts the focus on the function of metaphors; conceptual metaphors have a cognitive function; they reflect a way of thinking, in which a more abstract matter has been conceptualized with the help of a more concrete domain. This does not necessarily involve language. If a conceptual metaphor is expressed in language, it is called a linguistic metaphor. Linguistic metaphors in Steen's definition are not used deliberately; they can be seen as traces of metaphorical thinking in language. They are differentiated from communicative metaphors, which are linguistic metaphors that are deliberately used with a communicative purpose. Communicative metaphors are not merely cognitive traces in language; they have a communicative function besides the cognitive one.

Politicians not only deliberately use communicative metaphors to communicate their political style; they also use them unintentionally to express their style. Both types of metaphors are purposeful for the political identity they perform (see Chapter 7). Hence, both linguistic and communicative metaphors are relevant for political style, as well as the underlying conceptual metaphors. In political communication, metaphors often form larger units, clustered around themes. Dependent on the size of the clusters, these themes are called "systematic metaphors" (Maslen, 2017) or “metaphor scenarios” (Musolff, 2016, 2017).

This analysis looks for all types of metaphors, with a special focus on clusters of metaphors that are used to express a political style. The method to identify the metaphors is close reading. The method originates from literary studies; established in the nineteen-thirties by I. A. Richard, a literary scholar who is also known for his metaphor theory, it is a renowned approach of analyzing literary texts. It involves paying close attention to how texts with a literary purpose are produced by using linguistic strategies (Herrnstein Smith, 2016; Richards, 1936). Close reading has been applied to political metaphor by Charteris-Black $(2012,2014)$ and mostly aims at communicative metaphors used with a persuasive purpose. However, politics does not only involve persuasion; as mentioned in section 2, political style 
has three functions; besides persuasion, it involves the social connection with people and the expression of thought. So, not only communicative metaphors but also linguistic and conceptual metaphors are relevant. To ensure that less salient linguistic and conceptual metaphors were not missed, the MIP metaphor identification procedure was applied, as described by the Pragglejazz group (2007).

In all three speeches, all metaphors were identified first. As there was no quantitative goal, these were not counted; the focus was on identifying different kinds of metaphors. After the identification, metaphors that referred to the five target-domains mentioned in section 2 were analyzed. If those metaphors formed clusters with other metaphors, these metaphors were also included in the analysis.

A special focus was on metaphor scenarios; these can be regarded as mini-narratives that include a solution to a problem. They not only express thought; they mostly convey strategic or emotional implications. For instance, the lion metaphor mentioned is not only an expression of seeing the people as incapable of governing themselves, but it also implies a solution, as freeing the lion would be dangerous. Thus, the metaphor implies that it is good that the people do not govern themselves, and that the elite is needed to guide the people. This implication contrasts with the metaphor that depicts the people as slaves; in this scenario, setting the people free is implied as a goal, as slavery is generally seen as extraordinarily immoral and unlawful. There are mainly three functions of metaphors and metaphor-scenarios in a narrative: as described in Chapter 7, they can have a strategic, rational, or an emotional function, or a combination of the three. The analysis will assess the purpose of the metaphors used in the speeches and see if and how the speeches differ.

\section{Obama: The People as America}

Barack Obama delivered the speech analyzed here in 2016 during the Democratic Convention, in which Hillary Clinton's candidacy for the presidential elections officially was announced (Speech I). The main purpose of the speech was an endorsement for Clinton, which meant that Obama also denounced her Republican opponent, Donald Trump. In Chapter 5, the political style of the speech is assessed as pluralist. Summarized, this means that Obama speaks of himself as being part of the people (this is mixed populism/pluralism in the social realm); additionally, he does not see the people or the elite as one, homogenized group, but as individuals and smaller groups, like Latinos, blacks, and whites, that compete 
with each other but also unite as Americans (this is pluralist in the ideational dimension). Moreover, he does not directly speak for the people; on the contrary, he emphasizes that he communicates with the people, representing and helping them (this is mixed pluralism/elitism in the presentational realm). The scores on the three dimensions average out to a full pluralist profile. The metaphor analysis presented below is performed separately from the style analysis in Chapter 5. It focuses on the metaphors used for the five key elements of political style, as mentioned in section 2 .

\section{I The people.}

Obama often refers to the audience and himself (you, we) as "the people," as in this fragment:

I think it's fair to say this is not your typical election. It's not just a choice between parties or policies -- the usual debates between left and right. This is a more fundamental choice; about who we are as a people, and whether we stay true to this great American experiment in self-government. (I, 00:08:50)

It expresses that he views himself and the participants of the Democratic Convention as (part of) the people, which can be seen as metaphorical or as literal. The audience is part of the American people, and the speech was broadcast all over the country, so Obama literally addressed the people of the United States. However, this expression is metaphorical as well in relation to another metaphor in the speech; Obama often refers to the audience as the country, as in: "Hello, America!" In this way, he also identifies the people with the country. This schematic metaphor is supported by the conceptual metaphor of AMERICA/THE COUNTRY AS A PERSON/GROUP OF PERSONS, but also as the result of the cooperation between people, as in the following fragments: "America is already great. America is already strong. And I promise you, our strength, our greatness, does not depend on Donald Trump” (I, 00:23:44). And in: “America has never been about what one person says he'll do for us. It's about what can be achieved by us, together" (I, 00:27:10). In this chain of metaphors, Obama uses the metaphor of the country as a signifier for the people: everybody in America, black, white, Latino, man, woman, can identify with America. It is an inclusive metaphor for the people and perfectly fits Obama's pluralist view of the people. 


\subsection{The elite.}

Obama does not directly refer to the target domain of the elite because he does not recognize it as a separate category; in pluralism, everybody is part of the people. However, Obama does speak of politicians that normally can be regarded as part of the political elite: Clinton and Trump. As shown in the following example, he sees POLITICIANS AS CHAMPIONS, or, in the case of Trump, as a fake champion: "I came to realize that her unbelievable work ethic wasn't for praise; it wasn't for attention -- that she was in this for everyone who needs a champion” (Over Clinton) (I, 00: I4:50), and: “Does anyone really believe that a guy who's spent his 70 years on this earth showing no regard for working people is suddenly going to be your champion?"(Over Trump) (I, 00:20:23). Politicians are the champions of groups of people; they have won the contest to represent the people. The champion metaphor fits with Obama's view that politicians are part of the people, instead of the elite; it is a very meritocratic view of the elite. People become a champion by hard work, and not, like Trump, by being born rich.

\subsection{Politics and democracy/government.}

The champion metaphor is part of the metaphor scenario that Obama uses for POLITICS AS A CHALLENGE or a contest to create a better world, as in these fragments: "It's precisely this contest of ideas that pushes our country forward" (I, 00:09:22), "We are challenged to do better; to be better" (I, 00:II:08), and "After the worst recession in 80 years, we fought our way back." (I, 00:05:22). It is not a fight of the people against the elite, as in populism; it is a fight in which everybody cooperates - in a competitive way - for a better world.

Obama depicts DEMOCRACY AS AN INSTRUMENT to use for GOVERNING. The latter is the WORK that has to be done for the country: "Democracy works, America, but we got to want it -not just during an election year, but all the days in between" (I, 00:3 I:I2), and: "America has never been about what one person says he'll do for us. It's about what can be achieved by us, together, through the hard and slow, and sometimes frustrating, but ultimately enduring work of self-government." (I, 00:27:10) 


\subsection{The political context as a whole.}

When Obama speaks of the political context, he keeps the distance of a neutral observer. He speaks of it as a book or as a report, a statistical graph that is going up or down. The CONTEST scenario is also visible, in sentences such as "we fought our way back" after the financial crisis: "We've seen deficits come down, $40 \mathrm{l}(\mathrm{k}) \mathrm{s}$ recover, an auto industry set new records, unemployment reaches eight-year lows, and our businesses create 15 million new jobs" (I, 00:05:22), and: "We opened up a new chapter with the people of Cuba..." (I, 00:06:32)

\begin{tabular}{|c|c|c|c|c|c|}
\hline $\begin{array}{l}\text { Purposes of } \\
\text { Obama's } \\
\text { metaphors }\end{array}$ & $\begin{array}{l}\text { People } \\
\text { metaphors }\end{array}$ & $\begin{array}{l}\text { Elite } \\
\text { metaphors }\end{array}$ & $\begin{array}{l}\text { Politics } \\
\text { metaphors }\end{array}$ & $\begin{array}{l}\text { Government } \\
\text { /democracy } \\
\text { metaphors }\end{array}$ & $\begin{array}{l}\text { Political context } \\
\text { metaphors }\end{array}$ \\
\hline \multirow[t]{2}{*}{$\begin{array}{l}\text { Ideational } \\
\text { (cognitive) }\end{array}$} & $\begin{array}{l}\text { Framing } \\
\text { America as } \\
\text { strong } \\
\text { (opposed to } \\
\text { Trump's } \\
\text { frame of } \\
\text { America as } \\
\text { not great) }\end{array}$ & $\begin{array}{l}\text { Reframing } \\
\text { people vs. } \\
\text { elite into } \\
\text { people and } \\
\text { their } \\
\text { champions } \\
\text { (no internal } \\
\text { divide) }\end{array}$ & $\begin{array}{l}\text { Framing politics } \\
\text { as working on a } \\
\text { better world. } \\
\text { Elections as a } \\
\text { contest; } \\
\text { politicians as } \\
\text { competing who } \\
\text { does this best. }\end{array}$ & $\begin{array}{l}\text { Framing } \\
\text { governing as } \\
\text { hard work for } \\
\text { the people, and } \\
\text { democracy as an } \\
\text { instrument for } \\
\text { that work. }\end{array}$ & $\begin{array}{l}\text { Framing the } \\
\text { context as a } \\
\text { book or as a } \\
\text { graph that is } \\
\text { going up. } \\
\text { Obama as a } \\
\text { reader/observer }\end{array}$ \\
\hline & \multicolumn{5}{|c|}{$\begin{array}{l}\text { Reframing Trump's populist frame (people vs. elite) into a pluralist frame (getting } \\
\text { political results together) }\end{array}$} \\
\hline \multirow[t]{2}{*}{$\begin{array}{l}\text { Emotional } \\
\text { (social) } \\
\text { I+S }\end{array}$} & $\begin{array}{l}\text { Expressing } \\
\text { optimism, } \\
\text { strength. } \\
\text { Empowermen } \\
\text { t, "we can do } \\
\text { it" }\end{array}$ & $\begin{array}{l}\text { Evoking } \\
\text { positive } \\
\text { feelings for } \\
\text { Clinton/aversi } \\
\text { on of Trump }\end{array}$ & $\begin{array}{l}\text { Engaging the } \\
\text { people in a } \\
\text { positive } \\
\text { movement: "we } \\
\text { can do it" }\end{array}$ & $\begin{array}{l}\text { Evoking } \\
\text { admiration: } \\
\text { politicians are } \\
\text { hard-working } \\
\text { and helpers }\end{array}$ & $\begin{array}{l}\text { Evoking positive } \\
\text { feelings and } \\
\text { trust: it is going } \\
\text { well. }\end{array}$ \\
\hline & \multicolumn{5}{|c|}{$\begin{array}{l}\text { Engaging the people in a positive movement: "We can do this" together with } \\
\text { politicians }\end{array}$} \\
\hline \multirow[t]{2}{*}{$\begin{array}{l}\text { Strategic } \\
\text { (presentatio } \\
\text { nal) } \\
I+S+P\end{array}$} & $\begin{array}{l}\text { Unify the } \\
\text { people - } \\
\text { reframing the } \\
\text { political } \\
\text { debate }\end{array}$ & $\begin{array}{l}\text { Reframing the } \\
\text { political } \\
\text { debate, } \\
\text { winning votes } \\
\text { for Clinton }\end{array}$ & $\begin{array}{l}\text { Putting focus on } \\
\text { political results } \\
\text { and experience, } \\
\text { which is } \\
\text { advantageous for } \\
\text { Clinton }\end{array}$ & $\begin{array}{l}\text { Putting the } \\
\text { focus on the } \\
\text { amount of work } \\
\text { and effort that } \\
\text { governing takes }\end{array}$ & $\begin{array}{l}\text { Focus on } \\
\text { changing things } \\
\text { for the better } \\
\text { (from a positive } \\
\text { feeling, not } \\
\text { negative) }\end{array}$ \\
\hline & \multicolumn{5}{|c|}{$\begin{array}{l}\text { Putting the focus on the hard work that politicians do. Showing Clinton as fit for the } \\
\text { job - as she is known as experienced and a hard worker. }\end{array}$} \\
\hline
\end{tabular}

I: Ideational dimension-- S: social dimension -- P: Presentational dimension

Table 8.I Purposes of Obama's metaphor usage. 


\subsection{Purposes}

Obama's primary purpose of his metaphors is the (re)framing of the debate (see Table 8.I). He often opposes his frame to the way that Trump views the world. Ideationally, he tries to reframe Trump's populist frame in his own pluralist frame. On the emotional level, he aims at empowering the people by expressing his belief in them. Strategically, he aims at letting the people choose for political experience and results (so, for Clinton), instead of choosing for the antagonism of the people against the elite. All three purposes entail reframing of the debate, which has to be seen as the main purpose of Obama's metaphors used in this speech.

\section{Johnson: The People as Animals or Slaves}

The speech by Boris Johnson was held at the British Conservative Party Conference, October 2017 (Speech 10). Johnson spoke in his role as Secretary of State for Foreign Affairs, and the primary purpose of this speech was the presentation of his foreign policy, and more generally, his Brexit-agenda, a year after the Brexit referendum had resulted in a vote to leave the EU. As the government was in negotiation with the EU on a Brexit-deal, this speech can also be seen as a popularity contest between Johnson, leader of the hardBrexit line, and Theresa May, representing a soft-Brexit policy.

As already mentioned in section 2 , the political style of this speech is assessed as mainly elitist in Chapter 6. Ideationally, Johnson sees the people as one (mixed populist/elitist). Socially, Johnson is part of the elite (elitist) but also fighting with the people against another elite (mixed elitist-populist). Presentationally, he identifies with the elite, but also with the people and the elite together against the EU (mixed elitist/populist). Hence, Johnson's elitism has some populist traits, but the average score remains within the full elitist reach. The metaphor analysis presented below is an addition to the style analysis.

\section{I The people}

Unlike Obama, Johnson does not refer to himself as the people: the people are always "they." When Johnson uses "we," he mostly refers to Britain or the country; to the elite and the people together. The metaphors that Johnson uses for the people are either 
domesticized animals or slaves; this depends on the elite members he relates the people to. His opponents - the socialist party and the EU bureaucrats in Brussels - are slaveholders or traders, with the people as slaves: "The shadow leader and shadow chancellor are seriously proposing to put place the British people back in bondage." (10, 00:09:50)

In contrast, Johnson and his fellow elite members relate to the people as a lion tamer to a lion, or as cattle and owner of the cattle. Johnson and his fellow elite members treat the people well, whereas the slaveholders abuse the people: "We are not the lion. [symbol of England] We do not claim, like some others, to be the lion. That role is played by the people of this country. But it is up to us now - in the traditional non-threatening, and genial, selfdeprecating way of the British - to let that lion roar." (10, 00:28:0I)

Comparing the people with an animal usually is an insult, but it does not have to feel this way because it is a traditional metaphor for the people. For instance, in Christianity, it is common to refer to the people as flock and to Christ as the Shepherd. The difference is that in the latter all people are flock, and in Johnson's metaphor only the people are animals and the elite not.

\subsection{The elite}

Johnson's metaphors for the elite are twofold: the good elite (he and his fellow Tories) are depicted as elite members with a positive image; a pharaoh, a guide (of the people), the winner of the game, a lion tamer, or a doctor who find cures. These are all images of natural leaders or helpers of the people: "Like the pharaohs of upper and lower Egypt, they are double hatted ministers" (10,00:0 I:46), and: "I believe we will eventually find a cure for the psychological contaminate on of radical Islamist extremism. Just as we have eradicated smallpox and polio.” (10, 00:21:36)

The bad elite (Corbyn, Labor politicians, and the media) are associated with elite members who abuse the people, or even worse, shown as zombies who are a threat to the people: "It (socialism) is back from the grave - its zombie fingers straining for the levers of power, and that is why we cannot rest" (10,00:10:50), and: "The shadow leader and shadow chancellor are seriously proposing to put place the British people back in bondage" (10, 00:09:50). 


\subsection{Politics and democracy/government}

Johnson depicts politics as a game, and himself as a winner: "And the only way to win the future is not to retreat from the world, not to abandon globalization but to play our part, as we always have, in making the world safer and freer." (10,00:12:36) Democracy is not something that the people already have; it is a goal that has to be reached, the destination of the travel that Brexit is: "the path to democracy and freedom.” Besides, Johnson speaks about politics as a competition between countries that Britain leads and wins. Mostly, this happens when he speaks of foreign policy - so this is more related to this content than to his political style, but it also fits into his view on politics as a contest.

\begin{tabular}{|c|c|c|c|c|c|}
\hline $\begin{array}{l}\text { Purposes } \\
\text { Johnson's } \\
\text { metaphors }\end{array}$ & $\begin{array}{l}\text { People } \\
\text { metaphors }\end{array}$ & $\begin{array}{l}\text { Elite } \\
\text { metaphors }\end{array}$ & $\begin{array}{l}\text { Politics } \\
\text { metaphors }\end{array}$ & $\begin{array}{l}\text { Government } \\
\text { /democracy } \\
\text { metaphors }\end{array}$ & $\begin{array}{l}\text { Political } \\
\text { context } \\
\text { metaphors }\end{array}$ \\
\hline $\begin{array}{l}\text { Ideational } \\
\text { (cognitive) I }\end{array}$ & $\begin{array}{l}\text { Framing the } \\
\text { people as not } \\
\text { capable of } \\
\text { governing, } \\
\text { and not free }\end{array}$ & $\begin{array}{l}\text { Framing the } \\
\text { Conservatives } \\
\text { as competent } \\
\text { leaders and } \\
\text { others (Labor, } \\
\text { EU) as abusers }\end{array}$ & $\begin{array}{l}\text { Framing } \\
\text { politics as a } \\
\text { game and } \\
\text { himself as a } \\
\text { winner and a } \\
\text { strategic } \\
\text { player }\end{array}$ & $\begin{array}{l}\text { Democracy } \\
\text { as a travel } \\
\text { destination, a } \\
\text { goal + as } \\
\text { freedom }\end{array}$ & $\begin{array}{l}\text { Framing the } \\
\text { context as an } \\
\text { international } \\
\text { competition + } \\
\text { as a film or } \\
\text { graph (going } \\
\text { up) that one } \\
\text { sees }\end{array}$ \\
\hline
\end{tabular}

Framing politics as a game that Johnson wins and the people follow.

\begin{tabular}{|c|c|c|c|c|c|}
\hline $\begin{array}{l}\text { Emotional } \\
\text { (social) I+S }\end{array}$ & $\begin{array}{l}\text { Bonding with } \\
\text { elite } \\
\text { members, } \\
\text { being better } \\
\text { than the } \\
\text { people }\end{array}$ & $\begin{array}{l}\text { Evoking } \\
\text { positive } \\
\text { feelings for } \\
\text { conservatives } \\
\text { and mocking } \\
\text { labor }\end{array}$ & $\begin{array}{l}\text { Expressing } \\
\text { confidence; } \\
\text { daring the } \\
\text { audience to } \\
\text { be bold }\end{array}$ & $\begin{array}{l}\text { Evoking the } \\
\text { desire for } \\
\text { freedom and } \\
\text { the feeling of } \\
\text { being } \\
\text { imprisoned }\end{array}$ & $\begin{array}{l}\text { Positive } \\
\text { feelings: Britain } \\
\text { leads the } \\
\text { world, is } \\
\text { successful, can } \\
\text { stand on its } \\
\text { own }\end{array}$ \\
\hline
\end{tabular}

Expressing confidence and a daring attitude. Evoking desire for Brexit.

\begin{tabular}{l|l|l|l|l|l} 
& $\begin{array}{l}\text { Showing } \\
\text { eloquence }- \\
\text { political } \\
\text { power play }\end{array}$ & $\begin{array}{l}\text { Gaining } \\
\text { support by } \\
\text { showing } \\
\text { eloquence and } \\
\text { knowledge }\end{array}$ & $\begin{array}{l}\text { Showing } \\
\text { competence } \\
\text { to win the } \\
\text { game, gaining } \\
\text { support }\end{array}$ & $\begin{array}{l}\text { Gaining } \\
\text { support for a support for } \\
\text { hard Brexit }\end{array}$ & $\begin{array}{l}\text { Gaining } \\
\text { (Presentational) } \\
\text { I+S+P }\end{array}$
\end{tabular}

Gaining support through eloquence and competence, and through framing politics as a game that fits his bold attitude. Presenting himself as successful.

I: Ideational dimension-- S: social dimension -- P: Presentational dimension

Table 8.2 Purposes of Johnson's metaphor usage. 


\subsection{The political context}

Like Obama, Johnson speaks about the context as a graph that goes up (due to the government), or as a film that you watch. Like Obama's book metaphor, this suggests distance and the neutrality of an observer: “... has seen inequality not rise but fall (...) to the lowest levels for three decades” (10,00:1 I:42). He also refers to the political context as a journey that has been made, and from which one comes back. Besides, problems can be handled with a "Swiss army knife," which refers to the military, but also to adventurous journeys in which such knives are a necessity. Problems are things you can cut with a knife, or nuts to be cracked. Mostly, however, the political context is a competitive game, played by countries and politicians: "We lead the world in bio-science and fin-tech..." (10, 00:25:54)

\subsection{Purposes}

With his metaphor usage, Johnson creates a purposeful narrative structured around the goal to gain support for himself as a leader (see table 8.2). First, politics is framed as a competitive game, a game that requires guts and a bold attitude to win. Subsequently, Johnson portrays himself as having the right character and leader capacities to win this game; he has guts and knows how to play. He stimulates the people to be daring and confident and go for a hard Brexit. Supporting him means a winning game for all spectators. A daring attitude, for which he is famous, will be rewarded, and a less daring attitude, like for instance that of Theresa May's soft Brexit policy, will not. He mostly gains support through eloquence and showing proficiency as a leader.

\section{Wilders: The People as Heroes, Liberating the Country}

The Dutch politician Geert Wilders held the two speeches analyzed during the six months before the Dutch elections in March 2017; one on a European platform in January 2017 (Speech 2I), and the other in September 2016 (Speech 20), on a yearly debate in Dutch parliament, the General Assessments, which is broadcasted and always gets a lot of media attention. Because the platforms differ, the speeches can be seen as complementary; they contain many identical sentences and parts of sentences, but the first speech is aimed at a broader public, whereas the second speech is directed towards a public that is already on 
the same wavelength as Wilders. The overarching goal is winning support for his party and for sister parties in Europe.

In my previous political style analysis, the speeches were assessed as fully populist in all three dimensions; Wilders speaks of the people as a good homogeneous group and the elite as a bad homogeneous group (ideationally populist); Wilders is part of the people (socially populist or pluralist), and he speaks directly for the people (presentationally populist). This results in an average score of a full populist political style. The following metaphor analysis is complementary to the style analysis, which is more elaborately reported on in Chapter 5.

\section{I The people}

Like Obama, Wilders speaks of the people as "we," and he often equates the people with the country. The difference is that in Wilders' speech the people are not only metaphorically the country, they are also the rightful owners of the country: "We are the Netherlands, and this is our country" $(22,00: 02: 45)$. Wilders' country is the private property of the native Dutch inhabitants. Immigrants are associated with terrorists and thieves who threaten to take away the country from its rightful owners:

"We will reclaim it [our country]. From today onwards. We will no longer allow that our women and daughters are harassed by you; that our neighborhoods are terrorized; our stores robbed; that the elderly no longer dare to go for a walk at night; (...) That the Netherlands gets destroyed. We no longer accept that.” (22, 00:02:50)

Wilders depicts the people as asleep, not aware of the danger of losing their country. They have to wake up: "We are losing our country. Forever, if we don't wake up very soon" (22, 00:00:08), and: "If we do nothing, if we do nothing, then we cease to exist." (21, 00:10:30).

Fortunately, according to Wilders, many people are waking up; these people, the supporters of Wilders and other European right extremist parties, are "awake," and the saviors of the country and the people: "They are blind to the truth, but we are not!" (2I, 00:06:17), or: "The people in Western countries are waking up" (21, 00:21:25), and: "You are the heroes and saviors of Europe. I thank you for that." (2I, 00:18:36) 


\subsection{The elite}

Wilder's elite is blind, drunk, a coward, and looking the other way: unable and unwilling to see the danger that the people are losing their country. They are "gamblers" (they gamble with the people's rights), or too anxious to act: "This is only possible if we do away with - as we do now - political cowardness and looking away from problems" (22, 00:42:06). The elite has abandoned the people, which is why the people have to wake up. They cannot trust the elite to defend them: "Because the people should not be left behind. We, we here altogether, we are the hope of the people. And we will never disappoint them. Never" (2I, 00:13:00).

\subsection{Politics}

Wilders often speaks about politics in war metaphors. He fights a "capitulation culture" (22, 00: I I:38); Political parties are "arch enemies" (22, 00:1 I:45); We are going to "conquer the country back" (2I, 00:20:00); We "fight back" (22, 00:03:26). The goal of this war is to free the people and rescue the country. Politicians such as Wilders are the instrument in this liberation. As in: "My friends! This year will be the year of the people. (...) The year of the liberation” (2I, 00:20:10). And: "The people in Western countries wake up. (...) They want their freedom back. They want their sovereign nations back. And we, the European Patriots, we will be their instrument. Long lives Freedom.” (21, 00:22:07) Or: "History calls upon us to save Europe. To save our own humanistic, Jewish-Christian culture and civilization, our freedoms, our nations, the future of our children.” (2I, 00:16:30)

\subsection{Democracy/government and political context}

Just as politics is "the liberation of the people," so the democracy is the means through which the people can liberate themselves, by voting for Wilders: "This year is the year of the people (...) The year of a democratic and peaceful political revolution in Europe" (2I, 00:20:10), and: "In two months,' in March, we will give the Dutch people the opportunity to liberate the Netherlands!” (21, 00: 02:47). For Wilders, not only politics is war, the whole context is (against Islam). It is: "a dark tunnel" (2I, 00:14:30) or a "black summer of the Jihad" (2I, 00:20:43). But there is light at the end of the tunnel: Wilders sees a "patriotic 
spring" (2I, 00:02:10). He dreams of a future in which "Islam is just a nightmare that has passed" $(22,00: 43: 34)$.

\subsection{Purposes}

The main purpose of Wilders' metaphor usage is polarization, the construction of a boundary between the people and foreigners that want to steal the country from its rightful owners (see Table 8.3). His WAR metaphor does not allow friendly cooperation between politicians from different parties. These are "arch enemies" who have given the country away to foreigners, leaving the rightful owners of the country empty-handed.

\begin{tabular}{|l|l|l|l|l|l|}
$\begin{array}{l}\text { Purposes } \\
\text { Wilders' } \\
\text { metaphors }\end{array}$ & $\begin{array}{l}\text { People } \\
\text { metaphors }\end{array}$ & $\begin{array}{l}\text { Elite } \\
\text { metaphors }\end{array}$ & $\begin{array}{l}\text { Politics } \\
\text { metaphors }\end{array}$ & $\begin{array}{l}\text { Government } \\
\text { /democracy } \\
\text { metaphors }\end{array}$ & $\begin{array}{l}\text { Political } \\
\text { context } \\
\text { metaphors }\end{array}$ \\
\hline $\begin{array}{l}\text { Ideational } \\
\text { (cognitive) }\end{array}$ & $\begin{array}{l}\text { Framing native } \\
\text { Dutch as the } \\
\text { rightful owners } \\
\text { of the country }\end{array}$ & $\begin{array}{l}\text { Framing other } \\
\text { political parties } \\
\text { as bad and } \\
\text { unwilling }\end{array}$ & $\begin{array}{l}\text { Framing } \\
\text { politics as } \\
\text { war, and the } \\
\text { country as } \\
\text { occupied }\end{array}$ & $\begin{array}{l}\text { Democracy as Framing } \\
\text { freedom and } \\
\text { change }\end{array}$ & $\begin{array}{l}\text { political } \\
\text { events as } \\
\text { war }\end{array}$ \\
\hline
\end{tabular}

The people as in war with enemies, fighting for freedom and abandoned by the elite

\begin{tabular}{l|l|l|l|l|l|}
\hline $\begin{array}{l}\text { Evoking fear of } \\
\text { loss/support } \\
\text { for his policy }\end{array}$ & $\begin{array}{l}\text { Evoking strong } \\
\text { negative } \\
\text { emotions } \\
\text { (social) }\end{array}$ & $\begin{array}{l}\text { Evoking } \\
\text { against the elite } \\
\text { I+S }\end{array}$ & $\begin{array}{l}\text { emotions of } \\
\text { being in a } \\
\text { war, under } \\
\text { attack }\end{array}$ & $\begin{array}{l}\text { Positive, } \\
\text { expressing joy fear and } \\
\text { and success anger }\end{array}$ \\
& & & &
\end{tabular}

Evoking negative emotions: fear, anger, loss, war. And positive feelings of success.

\begin{tabular}{|c|c|c|c|c|c|}
\hline $\begin{array}{l}\text { Strategic } \\
\text { (Presenta- } \\
\text { tional) } \\
\text { I+S+P }\end{array}$ & $\begin{array}{l}\text { Polarization: } \\
\text { Constructing a } \\
\text { boundary } \\
\text { between the } \\
\text { people/others }\end{array}$ & $\begin{array}{l}\text { Polarization: } \\
\text { constructing a } \\
\text { boundary } \\
\text { between the } \\
\text { people /elite }\end{array}$ & $\begin{array}{l}\text { Placing } \\
\text { oneself in the } \\
\text { underdog } \\
\text { position }\end{array}$ & $\begin{array}{l}\text { Encourage } \\
\text { people to join } \\
\text { the success }\end{array}$ & $\begin{array}{l}\text { Gaining } \\
\text { support } \\
\text { through } \\
\text { negative } \\
\text { emotions }\end{array}$ \\
\hline
\end{tabular}

Polarization, taking the underdog position and presenting himself as successful.

Note: I: Ideational dimension-- S: social dimension -- P: Presentational dimension

Table 8.3 Purposes of Wilders' metaphor usage. 


\section{Conclusion and Discussion}

This chapter shows contrasts and commonalities between the metaphors used in a populist, elitist, and pluralist speech. In all the speeches, the metaphors are used as a persuasive framing strategy. Johnson's depiction of politics as a daring game makes him look like a good choice, as he is known for his bold character. Obama's depiction of politics as a challenge that requires hard work implies Clinton is a good fit, as she is known for her hard work and perseverance. Wilders depiction of politics as a war fits his polarization strategy. It shows that all three speakers succeed in creating a metaphorical environment that fits their rhetorical goals best.

Besides this rhetorical use, the metaphors contribute to the political style of the politicians; either a populist, or elitist, or pluralist style. Exploring populist speeches in direct contrast with contradictory styled speeches is fruitful; it not only shows what populist metaphors look like but, more importantly, what they do not look like. Understanding what populism is-not is crucial because politics is a creative process, and new expressions of populism are endless. However, all new metaphors are restricted by the boundaries of what populism is-not. In order to delineate those boundaries more precisely, the differences and similarities in metaphor usage in the analyzed speeches will now be considered more closely.

First, all three speeches depict politics as a fight. This aligns with observations in other metaphor research that politics is commonly depicted with the conceptual metaphor of FIGHTING or WAR (Flusberg, Matlock, \& Thibodeau, 20I8; Lakoff, 20I4; Musolff, 2016). However, this analysis highlights the point that not all metaphorical wars are the same. Only in the populist speech is politics portrayed as a fully-fledged, literal war, relating to the populist antagonism between the people and the elite. This fits with the observation that populist politicians often use war metaphors for politics in general (Flusberg et al., 2018, p. 6). In the elitist speech, politics is also depicted as war, but this happens in combination with the metaphor of politics as a COMPETITIVE GAME; this is a "fight" as well, even "a battle of ideas," and it refers to the conventional, ubiquitous metaphorical application of the war metaphor for argument and game (Dancygier, 2017), and not to a literal war. The difference with a literal war is that outside politics, the participants in the fight can still be friends; after all, it is only a game.

The pluralist speech analyzed also depicts politics as a game, but not a competitive sports game with a clear winner and loser; politics is A CHALLENGE or A CONTEST in which all 
participants work together. It is often a "fight" and sometimes even a "battle," but there is not one winner or loser; everybody gains in the end and remains friends even during the game. This differentiation between WAR metaphors suggests that, for instance, Bush's "war on terror," and Nixon's "war on drugs" are not primarily populist. These "wars" refer to a challenge on which all people work together. This is a pluralist use of the war metaphor. On the other hand, the emotional weight of the WAR metaphor adds to a populist social style; however, this is, at most, partly populist because the ideational part is pluralist (detailed features of political styles in appendix D). Analysis of the speeches by Bush and Nixon can enlighten us as to which style they predominantly use.

Second, the speech analysis suggests that metaphorically speaking of the people as "captured animals" and of politicians as their "caretakers" or "tamers" is typically elitist, so non-populist. In both populism and pluralism, this metaphor is unthinkable because it shows the speaker to be not part of the people. Speaking of the people as "we" is not specifically tied to one style (it can be populist or pluralist), and speaking of the people as "the nation" is even possible in all styles, as it can refer to the people, or to the people and the elite together. Only not speaking of the people as "we," but consistently as "they," or even as "animals" can be characterized as typically elitist as it expresses the elitist feature of the people as an audience that does not govern.' This confirms that Johnson is better characterized as an elitist than as a populist, as he consistently refers to the people as "they".

Third, in the populist speech, the people are depicted as the rightful owners of a country. It expresses the people as being one homogenized group, and can, for this reason, be seen as an expression of populism. However, it is questionable whether it is typically populist because elitism also sees the people as one homogenized group. The metaphor is possibly more tied to nativism or nationalism because these concepts unite the people with the elite; however, this needs further investigation.

Fourth, the analysis shows that, as suggested by Van Leeuwen (2019), simply counting the number of references to the people does not suffice for measuring populism in political text or talk. Van Leeuwen already showed that grammatical differences matter for the people centrism in a text; additionally, this analysis shows that metaphorical differences can result in a completely different style. Hence, it is the way in which these references are made, that make the difference between populism and other political styles.

Fifth, the analysis suggests a link between the three styles and the three means of persuasion described by Aristotle: ethos, pathos, and logos (Aristotle, trans. 1984). The main 
purpose of the elitist speech (Johnson) is to gain support by showing eloquence and a good character - ethos in Aristotle's rhetoric. The main purpose of the pluralist speech (Obama) is reframing Trump's populist frame into a pluralist one - which has to do with how you think, or the logos. Wilders' populist main purpose was polarization, which is a matter of pathos. In theory, the link is logical. In elitism, the people have to trust the elite based on their good character (ethos) because they are themselves not able to govern. In pluralism, the people judge policies on the content (logos), because everybody should be involved in politics to prevent power abuse. In populism, politicians are considered good if they are one of us, which is based on a feeling (pathos). Notwithstanding this theoretical link, a straightforward connection between populism and pathos seems to be too simple as all three means of persuasion (ethos, logos, and pathos) are used in all speeches to support the main purpose. In order to understand in more detail how this works, further research is needed.

To conclude, the in-depth analysis of a populist, elitist, and pluralist speech has been insightful. Particularly the differences in the use of the WAR metaphor and the means of persuasion (pathos, ethos, logos) would be worth exploring further. As Musolff (2016) suggests, a corpus analysis could confirm whether the observed patterns are more broadly detectable. The amount of populist discourse that is being produced at this moment gives us ample material to work with. 


\section{9 \\ Conclusion}

Political Style, a Matter of Framing

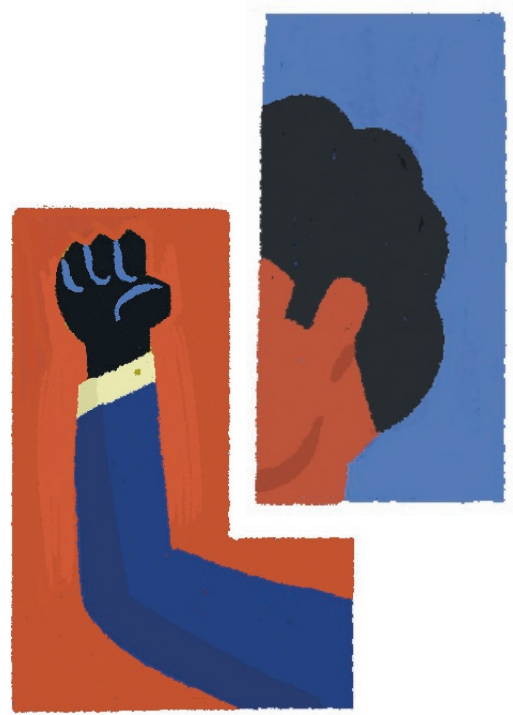


Reframing is changing the way the public sees the world.

It is changing what counts as common sense.

George Lakoff, Don't Think of an Elephant, p.xv

\begin{abstract}
This concluding chapter discusses the overall conclusions of this dissertation against the background of the academic literature on the topic. Being interdisciplinary, this dissertation contributes to various academic discussions. Conceptually, it contributes to the political style concept, the populism concept, and the concept of political metaphor. Methodologically, it adds a new speech analysis method to the existing tools for political discourse analysis. In terms of political analysis, this dissertation adds to our understanding of current political developments. The five topics are subsequently discussed in the following five sections.
\end{abstract}

\title{
I Contributions to the Political Style Concept
}

In the literature, the political style concept was severely underdeveloped, and an important part of this dissertation consist of building up a theory of political style for the use of political analysis. This section discusses three main developments of this theory in relation to the existing literature on political style.

\section{I.I Three-dimensional style.}

Traditionally, political style has been seen mainly as rhetoric, which emphasizes the persuasive function of political style (Cicero, trans. 2012; Hariman, 1995). This broadly equates to the presentational dimension of political style in this dissertation. At the end of the 20th century, Ankersmit and Pels highlighted the various relational aspects of political style (Ankersmit, 1996; Pels, 2003a). Their approach broadly translates to the social dimension in this dissertation; when it recognizes aspects from other dimensions, these aspects comply with the social function of political style. More recently, Koenis (2014) has defined political style as a manner of solving political problems. This approach highlights ideational elements of style (framing) as well as social elements (policies). Besides, Moffitt 
and Tormey have defined political style as a performance (Moffitt, 2016; Moffitt \& Tormey, 2014). This definition acknowledges features in three dimensions but specifically highlights the social and ideational parts that are visible from the presentational dimension.

Hence, all existing approaches partly cover the topic of political style. The style concept in this dissertation claims that, in order to gain a profound understanding of political performances, the analyst must consider the three dimensions separately; as the expression of ideas, a social act, and a performance on the political stage. This is because each dimension highlights and hides different aspects of political style. Only by consciously and deliberately changing the angle of analysis, can aspects be revealed that would otherwise have stayed out of sight.

An example of an expression having divergent meanings in three dimensions is the elite image of the Dutch populist politician Thierry Baudet. Generally, good manners are seen as contradictory to populism (Moffit, 2016; Ostiguy, 2017). One way to explain this apparent contradictory performance is to consider political style separate from ideas. This interpretation does not deem Baudet's style populist, only his ideas (Rooduijn, 2019). This interpretation is grounded in the broadly acknowledged ideational approach of populism (i.e., Mudde, 2017). As an alternative, this dissertation suggests a three-dimensional interpretation of Baudet's political manifestation of good manners, as follows:

- His good manners are elitist in the ideational dimension, expressing the idea that the elite are the helpers of the country, working for the greater good. In the ideational dimension, Baudet combines his elitist manners with populist or mixed populist-elitist (anti-pluralist) style elements; for instance, depicting the people as a good homogeneous group (populist) and expressing that his own values are not opinions, but the real truth (populist-elitist). This results in an average mixed populist-elitist ideational style profile.

- In the social dimension, his good manners can be interpreted as mixed populist-elitist. Not only is Baudet himself a part of the elite (elitist), but he claims that the same can be said for the Dutch people as a whole; the Dutch being descendants of high culture, known for their world-famous painters, writers, and scientists. The not-elite are the notwestern, not-white cultures. Hence, with his culturally educated image, Baudet expresses to be part of this (elite) people. This is assessed as populist, which results in an average mixed populist-elitist social style profile. 
- In the presentational dimension, his good manners can be understood as fully populist. Due to populist influences, most mainstream politicians in the Netherlands emphasize their status as a normal person, rather than as part of the elite. Baudet's elite image is, therefore, entirely anti-political class, with the express purpose of contrasting mainstream politicians.

A more detailed analysis in Chapter 6 shows Baudet's style as more populist than elitist, yet still evidently a mix of the two. This is highly compatible with his right-wing, nationalist, and nativist agenda. The mixed profile describes his ideas better than a purely populist one. Hence, comprehending the entire performance of the politician adds to our insight into current political presentations. Of course, there can be reasons for limiting a research focus to just one dimension, but one should be aware that this is a restriction.

\section{I.2 Left-right-center politics and political style.}

By analyzing multiple speeches in three political contexts-the US, the UK, and the Netherlands-a pattern emerged that is worthy of investigating further: in all three contexts, left-centered populists are situated at the populist-pluralist (anti-elitist) side. This suggests that they mainly express populism in the social dimension: being part of the people and claiming power for the people. Additionally, right-centered populists are situated at the elitist-populist (anti-pluralist) side. This means that they mainly express populism as a set of ideas; for instance, that the people are a more or less homogeneous moral group. Populists that combine left and right features are close to the populist corner, combining the two sides. This means that they express populism in all three dimensions: ideational, social, and presentational. Lastly, analyzed mainstream politicians are positioned at the pluralist-elitist side of the triangular framework.

Complementing this analysis with political style analyses in more (Western and nonWestern) countries would reveal whether this spread across the triangular framework can be more widely observed. If this is indeed the case, it provides an explanation for the socalled horse-shoe model. This model is proposed as an alternative for a straight line depicting the political spectrum between left- and right wing politics (Koenis, 20I4; Pels, 2003b; Taylor, 2006). In a straight line model, the extreme-left and right are positioned the furthest away from each other, expressing that they are fundamentally different. Alternatively, the 
horseshoe model expresses that extreme-left and extreme-right wing politics, besides their differences, also often resemble one another.

Explanations for the horseshoe are diverse. Pels characterizes the two ends as more stylized politics than the content-centered middle (Pels, 2003b). Koenis points at the difference between culture relativism - seeing distinctive cultures as principally different-at the ends of the horseshoe and culture universalism - accentuating universal values -in the middle (Koenis, 20I4, p. 125). Taylor sees the middle of the horseshoe as connected with elitism because politicians occupying the center often hold power; the two ends can be seen as left and right-wing populism (Taylor, 2006, p. I I8). Although these explanations explain why the extreme right and left are simultaneously different and similar, they do not explain how this apparent paradox works. This is why others question the validity of the horseshoe conceptualization; they argue that the extreme left and right are too far apart to be even slightly associated with each other (Choat, 2017)

Projecting the triangle onto the horseshoe explains the logic behind the apparent paradox of proximity and distance of the far right and left. First, the projection in Figure 9.I suggests that combined elitism-pluralism forms the center of the horseshoe, instead of pure elitism as suggested by Taylor. Mixed elitism-pluralism depicts the current centrist political style better than elitism alone; the academic literature agrees that pluralism, in combination with unintentional elitism, has been the dominant political organization form in most Western countries throughout the latter half of the $20^{\text {th }}$ century (Blokland, 20I I; Dahl \& Stinebrickner, 2002; Lijphart, 1968). Also, Koenis' and Pels' differentiations between the center and the ends of the horseshoe (universalism versus relativism and stylized versus content-centered politics, respectively) correspond with features of mixed elitism-pluralism versus populism, as visible in the description of the speech analysis method in appendix $D$.

Second, the triangular framework answers to Choat's objection to the horseshoe model. Where the horseshoe suggests a meeting point of the extreme left and right at the end of the horseshoe, the triangular framework depicts this meeting point as not only a merging point but also a radical shift in view. The corners of the triangular framework show radical turning points in the main framing of the political context. This comprehensively explains the simultaneous differences and similarities of the extreme right and left; although right- and left-wing populism both share the same style elements in three dimensions, their main frame is fundamentally different. The left mainly sees the world through the social lens and demands a fair share. The right, on the other hand, views society mainly through the 
ideational lens, claiming that their vision of society-a vision based on the dominant (hence traditional) framings in language- -is the real truth. Although the populist left and right share the same framings of the three dimensions (the people as one, no power to the elite, and identification with the people), the two secondary dimensions are framed differently towards the main dimension, which results in a fundamentally dissimilar political style. For instance, it leads to the difference between a one homogeneous people, and a one, unified people (more on this in section 2.3 and 2.4 ).

The question might arise as to why the meeting points at the other two corners of the triangle are not as salient as the one between extreme right and left. The other two corners also mark fundamental changes of frame, and it is expected that this would be visible in a salient change of style. This is not the case because, here, the presentational dimension is involved, a dimension concerned with cooperation instead of opposition. The empathic character of the presentational frame makes its difference from other framings less visible.

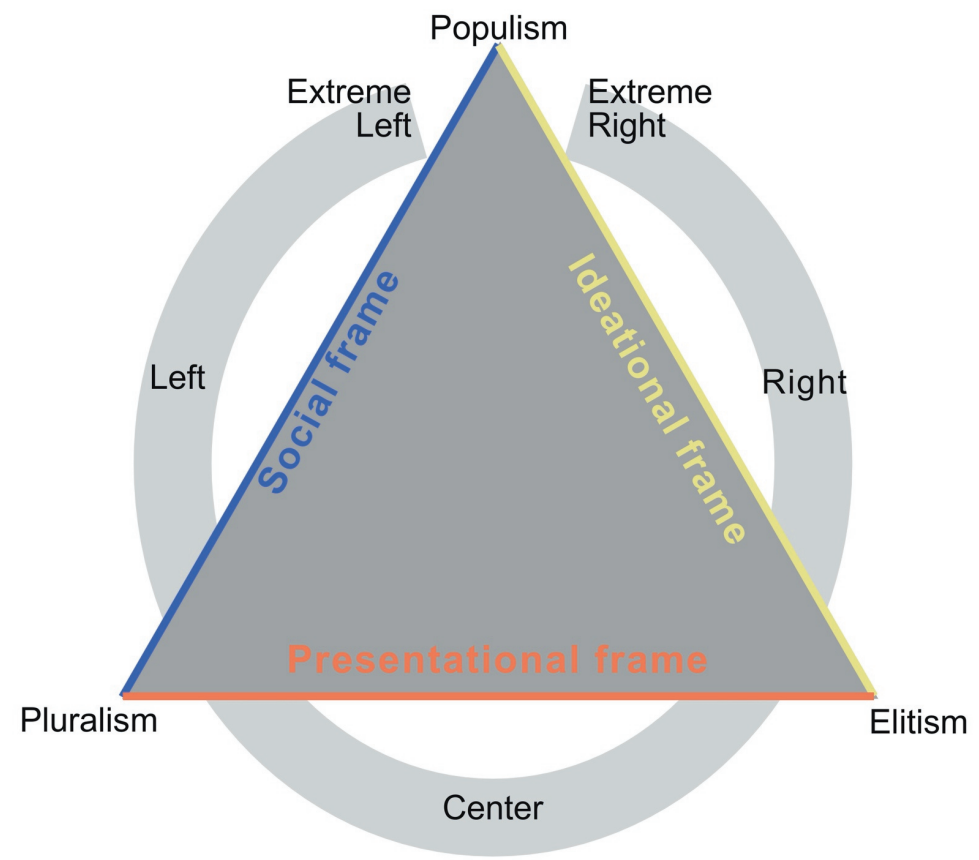

Figure 9.I The triangular framework projected onto the horseshoe model. 


\section{I.3 Mixing personal, group and systematic styles.}

This dissertation contributes to the concept of political style by analyzing it as a combination of a group style, personal style, and systematic style (see Chapters 2 and 4). At its core, a political style is a group style, as it is used to connect with a group of people (Ankersmit, 1996). However, a pure group style is utopian, as groups always consist of individuals, and therefore necessitate systems that can reconcile group and individual interests. Hence, mixes of group, personal, and systematic styles naturally emerge as realistic versions of a political (group) style. As depicted in Figure 9.2, populism, elitism, and pluralism-as well as their anti-styles - are the logically possible constellations that evenly spread a group, system, and personal component over the three dimensions of political style. They precisely complement each other and are, for this reason, a useful set of connected concepts with which to consider politics.

\section{Personal style}

Utopian: Individualism Dystopian: Egoism

\section{Group style}

Utopian: Collectivism Dystopian:Tribalism

\section{Systematic \\ style}

Utopian: Institutionalism Dystopian: Technocracy
(I) Individual logic
(s) Relating to other
S individuals
(P) Individual
(I) Group logic
(I) (heterogeneous)
(S) Part of /relating
to a group
P Group
presentation

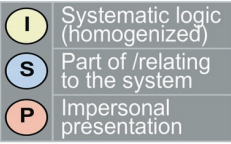

Realistic:

one dominant group style framing

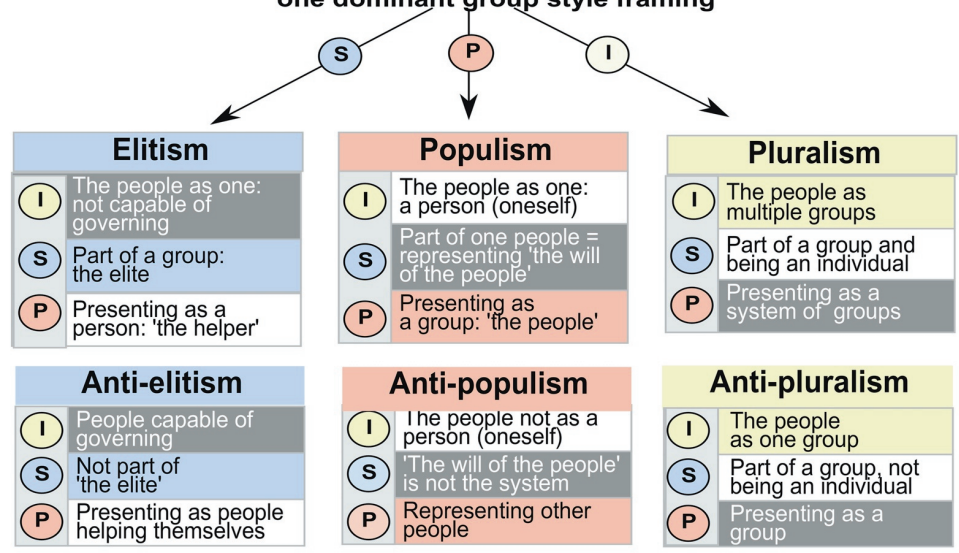

Figure 9.2 Populism, elitism, and pluralism as three realistic group styles, each mixing personal, group, and systematic style features. 
The six styles together form a closed system of political styles; they cover, within a closed space, all logically possible styles. However, as all analytical lenses are restricted, so is the lens chosen for this dissertation. For instance, by focusing on groups styles, this dissertation does not consider styles that are predominantly personal or systematic. In the same way that a group style incorporates personal and systematic elements, a personal or systematic style can carry elements from other styles. This appears to be the case with ideologies such as liberalism and fascism (both incorporating group and systematic elements within a mainly personal style) and communism (incorporating group and personal elements within a mainly systematic style). This means that in another closed space, other styles figure as the logical opposites of populism. Further analysis is required on the identification of the various concepts that figure in these.

The focus of this dissertation also does not consider unbalanced combinations within one style, such as two systematic parts and one group. Such combinations are, for instance, visible in a populist autocracy or an oligarchy. These phenomena fall beyond the scope of this dissertation, but they are certainly worth investigating further. For instance, such study could potentially answer the question of where populism changes from a democratic into a nondemocratic phenomenon, such as in a populist autocracy.

\section{Contributions to the populism concept}

In this dissertation, I critically engage with the arguments of various other scholars on the nature of populism. I want to emphasize that the analyses conducted in this dissertation would have been impossible without their work. The framework that I built is raised on the shoulders of their insightful analyses.

\section{I The nature of populism.}

The question of as to whether populism is a political style, a strategy, or a set of ideas/ideology has been elaborately debated in the populism literature, however, up till now, without an evident conclusion (e.g., Aslanidis, 2016b; Freeden, 2017; Gidron \& Bonikowski, 2013; Moffitt \& Tormey, 20I4; Mudde, 2017; Ostiguy, 2017; Pappas, 2016; Weyland, 2017). In light of the political style theory developed in this dissertation, this is not surprising. There is no main category, as the proposed categories of ideas, style, and strategy evidently 
correspond to the three dimensions in which populism occurs. These dimensions are circularly related; therefore, populism is inevitably all three at the same time. However, as the dimensions also contradict each other, populism never expresses itself in all dimensions at the same time; this would be an internally incoherent political style. Recently, the various existing approaches have been (re)categorized into three mainstream ones: (I) the ideational approach, (2) the political-strategic approach, and (3) the socio-cultural approach (Kaltwasser et al., 2017). This categorization does not pose the question of which approach fits populism best; all approaches contribute to our insight into populism in their own manner, which is a more fruitful perspective.

Researchers adhering to the ideational approach often argue that populist expressions in the social and presentational realm are merely an expression of populist ideas (Hawkins et al., 20I2, pp. 3-4; Mudde, 20I7; Rooduijn, 20I3, p. I63). However, not all aspects of populism are visible from a one-dimensional perspective, be it ideational, social, or presentational. More concretely: framing populism as a set of ideas, hides the commonalities between populism and pluralism; framing it as a strategy, hides the commonalities of populism and elitism; framing it as a rhetorical matter, hides the commonalities that it shares with both. Opposing populism to other concepts, such as technocracy or pragmatism, does not solve this problem either; other opposing concepts also regard the subject from the point of view of one leading dimension, and each dimension partly excludes the other dimensions' meanings.

Some approaches to populism use a mix of two dimensions. For instance, Laclau (2005a, 2005b) and Ostiguy (2017) view populism from both the social and presentational perspective. This is still not enough: only through making the three different framings visible by using shifting perspectives can populism be defined more completely. This is what I propose in this dissertation.

\subsection{The missing link between various populism approaches.}

The core structure underlying the constellation of populism, elitism, and pluralism is depicted in Figure 9.3. The structure can be summarized by one rule: the shared features of two of the three concepts will always contradict the third. This rule works as a grammar for the three concepts. No matter which features figure in the comparison between the three concepts - be they broadly accepted or contested - this logical rule is applicable, as this logic 
is the reason that these features can be considered potentially populist in the first place. By analyzing many features in the populism, elitism, and pluralism literature, this logic has been revealed.

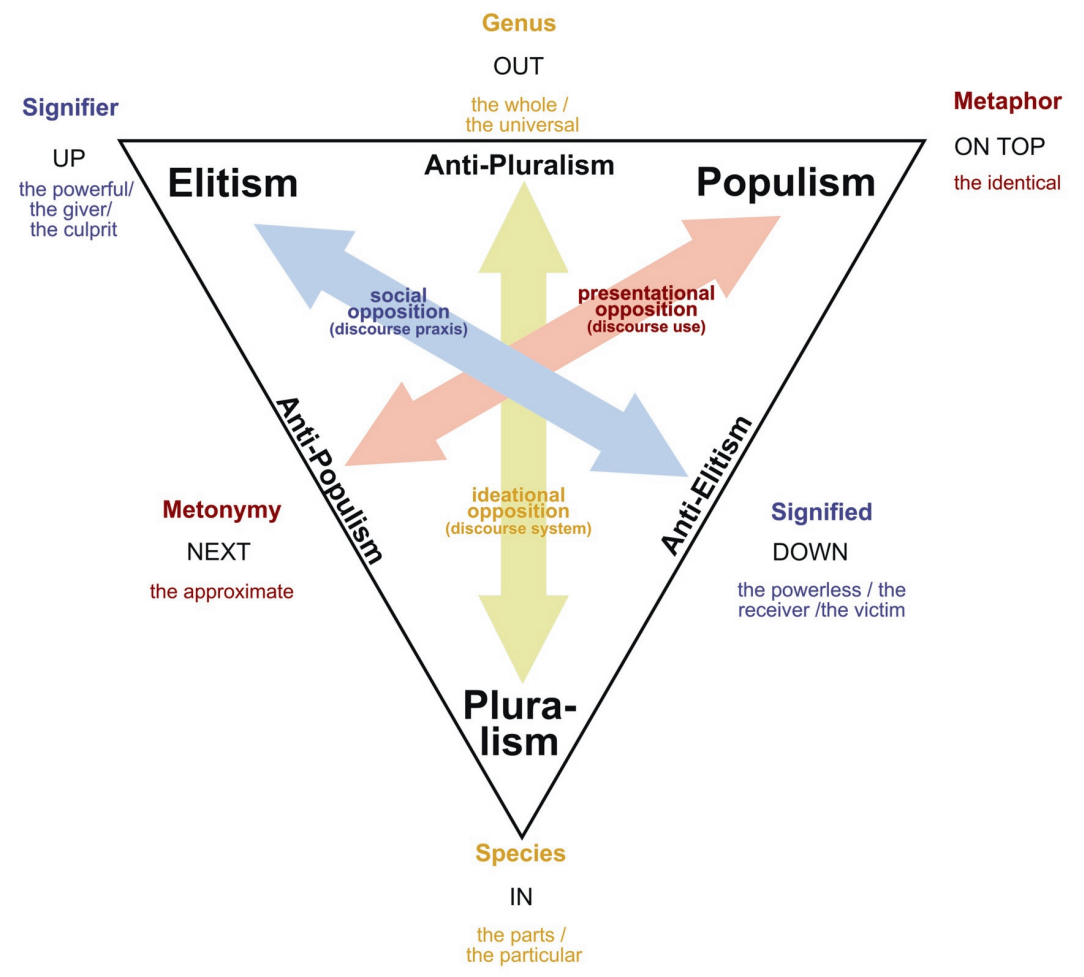

Figure 9.3 The semio-linguistic structure underlying populism.

This logic is elaborately discussed elsewhere in this dissertation. Examined here is the extent to which this framework is new. As explained in Chapter 4, practically all parts of populism's core-structure had already been mapped. Mudde had described the ideational dimension of this structure in his classical article the Populist Zeitgeist (Mudde, 2004). Aside from this, Hawkins mentioned several of the overlapping features of populism and pluralism (Hawkins et al., 20I2). Furthermore, Weyland's "populist twist" refers to the presentational feature of populism (Weyland, 2017). The social and presentational dimensions of populism were partly mapped by Ostiguy (2017) and by Laclau (2005a), etcetera. What lacked was the insight into how all this knowledge of populism links together. This is what this dissertation contributes to the literature: the underlying structure that connects the different approaches. On a more 
abstract level, as explained in Chapters 2 and 4, the labels populism, elitism, and pluralism can be replaced by other concepts-what is key is the oppositions they represent between:

- The opposition signifier-signified / the powerful versus the underdog: a social opposition

- The opposition species-genus / inclusive versus exclusive politics: an ideational opposition

- The opposition metonymy-metaphor / representing people versus being the people: a presentational opposition

The opposition between signifier-signified is social, as it concerns the relation between language and the thing to which language refers. This always involves power, as it is the powerful subject who decides which name (signifier) is given to a powerless signified object; though the signifier never accurately represents the object, the signified has no power to change that. The second opposition, between species and genus, is ideational (and not social) because it does not involve the link between language and the real world, but instead the relation between signifiers. It is purely located in language system and is, for this reason, an ideational matter. Because the ideational dimension is circularly related to the other dimensions (in the end, the language system is also part of discourse and open for change based on language use), it incorporates a power and presentational element, but only indirectly so. Lastly, the opposition between metaphor and metonymy (identifying with the subject, instead of approaching it) is rhetorical and belongs, for this reason, to the presentational dimension.

As visible in Figure 9.3, the three oppositions can also be characterized using the spatial oppositions in-out, up-down, and next to-on top of. These spatial labels are inspired by De Cleen's and Stavrakakis' (De Cleen, 20I7; Stavrakakis \& De Cleen, 20I7) use of the spatial oppositions up-down and in-out. The scholars define the up-down opposition as a characteristic of populism, whereas they see the in-out opposition as a characteristic of nationalism and nativism. They therefore claim that these two oppositions serve to differentiate populism from nationalism/nativism; in populism, discourse in predominantly structured around the up-down axis, whereas in nationalist discourse the in-out axis is pivotal. It is indeed true that in the social dimension populism differs from nationalism and nativism; in this dimension, populism is structured around the up-down opposition of the powerful against the underdog, whereas nativism and nationalism are not. This does not mean, however, that populism is not also structured around the in-out opposition. The two 
oppositions do not exclude each other, as they occur in different dimensions: the up-down in the social dimension, and the in-out in the ideational dimension. In the ideational dimension, populism finds itself on the same side as nationalism and nativism; they are all exclusive to some extent, as also as posited by Mudde and Kaltwasser (2012). Populists must exclude at least some people from their group; otherwise there would be no antagonism, no us versus them. In this sense, populism is similar to nationalism and nativism; they are all exclusive, albeit of different groups and in different gradations. Hence, in the opposition of exclusive versus inclusive, they are not opposed to each other but find themselves on the same side; both opposed to pluralism. Pluralism includes all groups and individuals: the elite, immigrants, anybody.

For the question where nationalism differs from populism it is, indeed, not very helpful "to label both the exclusion of national outgroups (...) and the populist exclusion of 'the elite' a matter of 'exclusion”' (De Cleen, 2017, p. II of 23). Alternatively, maybe it is helpful to focus the attention separately to the three dimensions in which populism and nationalism occur. The wider focus may provide new insights; for instance, the fact that populism and nationalism easily get entangled (Palonen, 2018) can be explained by their similarity in the ideational dimension.

Finally, the presentational opposition between next to and on top of is constitutive to populism, or, in linguistic terms, the difference between a metonymic versus metaphorical relationship with the people. Populists identify themselves with the people; they metaphorically make the people present in the political domain via their political performance. This opposes populism to both elitism and pluralism; in the latter two styles, politicians have a metonymic relationship with the people. They represent the people in the political domain, instead of making them immediately present.

\subsection{A non-heterogeneous people as part of populism.}

This dissertation also contributes to the academic discussion concerning whether or not a homogeneous people and exclusive politics is an inherent part of populism (De Cleen, 2017; Mudde \& Kaltwasser, 20I2; Stavrakakis \& De Cleen, 20I7; Stavrakakis \& Katsambekis, 20I4). An analysis of the populism-elitism opposition using the semiotic square of Greimas (1970/1987), exposes in 4 steps the underlying opposition of a heterogeneous (S) versus a non-heterogeneous people ( S) (see Figure 9.4). Logically, the opposition is not, as often 
assumed, between heterogeneous and a homogeneous people. Such an opposition contains a fallacy; the same fallacy found in equaling not-white with black, or not-alive with dead: the former terms are broader than the latter. Black, dead, and homogeneous are not just the opposites of white, alive, and heterogeneous; they all constrain the opposition to one meaning. The logically correct opposition of heterogeneous is non-heterogeneous: this includes not only the concept of homogeneous, but also those of equalized as one or unified.

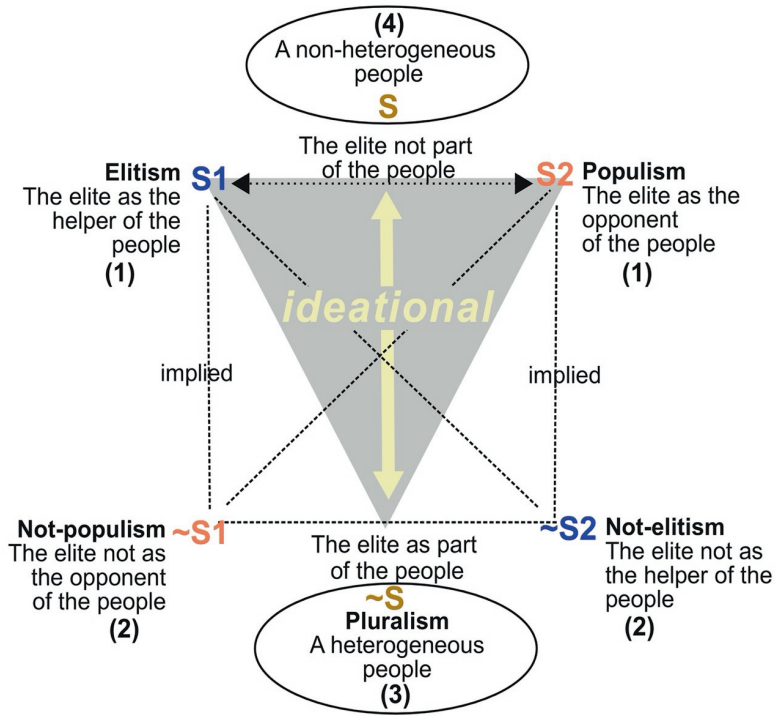

Step 1: Placing populism in opposition to eltism highlights some features and hides others; only features that match a shared underlying logic apply. Analyzing many features mentioned in the populism literature (as here, the elite as opponent or helper of the people) reveales this logic.

Step 2: The semiotic square systematically uncovers binary oppositions beneath opposite concepts, as follows: S1 and S2 both can be opposed to its negations $\sim \mathrm{S} 1$ and $\sim \mathrm{S} 2$. This constructs a second opposition, between $\sim \mathrm{S} 1$ and $\sim \mathrm{S} 2$, at the bottom of the square. This opposition is broader than the original one.

Step 3: In the broader meaning of the second opposition, the two concepts $\sim \mathrm{S} 1$ and $\sim \mathrm{S} 2$ unite in $\sim \mathrm{S}$.

Step 4: $S$ is defined as the opposite of $\sim S$. As more concepts apply to the meaning of 'nonheterogeneous', it cannot be further specified. It includes a homogeneous people as well as a unified people, equalized as one.

Figure 9.4 A Greimassian analysis of the opposition between a heterogeneous versus a nonheterogeneous people.

The deep structure of language restricts manifestations of populism and elitism to a nonheterogeneous people. It does not predict that a homogeneous people is part of populism; as long as the people are one in any sense (be it unified, homogeneous, or homogenized through populist or elitist rhetoric), it can ideationally count as populist (or elitist). On the other hand, it is too strong to state that the idea of a homogeneous people is alien to populism, as argued by scholars following Laclau. They reason that if the people are already homogeneous, they do not need to be unified by populism, for which reason an upfront homogeneous people must originate in the ideologies with which populism is combined, such as nationalism or nativism. Indeed, populism as an act partly defies populism as an idea, 
however, this does not mean that they are not both possible manifestations of the concept populism. At least, the structure underlying the concept allows both.

As outlined by Laclau (2005a), the logical route from individualism to populism takes multiple steps, steps that ultimately lead to a unified people that were not originally homogeneous. In Laclau's route to populism, the individual logic first changes into a group logic (ideational dimension); next, the elite is recognized as the common cause of heterogeneous unsatisfied demands (social dimension), based on which the signifier of the people is discursively constructed as a complaint against the people in power (presentational dimension). The latter two steps imply a non-heterogeneous people. This can be homogeneous from the perspective of the observer, but for the populist self, the people are unified, not homogeneous.

This route, however, is not the only path from individualism to populism. Alternatively, there is a short-cut in the underlying semio-linguistic structure that takes advantage of the fact that populism combines a group logic with a personal logic in the ideational dimension (see Figure 4.3). Ideationally, populism sees the people as a person (oneself). For this reason, it feels logically correct that one would keep one's personal logic in the transition from individualism to populism. If this process starts with the presentational dimension instead of the ideational (which remains personal), the social dimension automatically becomes populist as well, as this feature is implied by the other two (more elaborately, see Chapter 4). This short-cut takes someone in one step from individualism to populism. This process includes a homogeneous rather than unified people, because the people were never seen as multiple in the first place. This populist route is not based on the act of unification, as according to Laclau's definition of populism, but on the act of identification with the people and the retention of one's personal logic as an individual.

In sum, a homogeneous people is not integral to populism, but it is a possible expression process takes even less effort than the logical, unifying variant of populism. It explains why populism is often, but not always, combined with right-wing ideas.

\subsection{An inter-contextual definition.}

By using this relative definition of populism — understood in relation to elitism and pluralism-all political styles are assessed within their own contexts. This responds to Laclau's characterization of populism as inherently context-dependent; as an act of unifying 
the unsatisfied demands that exist in a specific context (Laclau, 2005a). Nevertheless, Greimas (19070/1987) states that the deep semio-linguistic structure of language restricts the logic behind the contextual manifestations. It follows, then, that styles become comparable on an inter-contextual level after they have been established within their context. With this, the analysis tool heeds Van Kessel's (20I4) warning not to mix features of populism that refer to different abstraction levels, as exemplified in Sartori's (I99I) catdog concept. To stay within the cat-dog analogy: first cats are compared with cats, and dogs with dogs to see what kind of pet these individual cats and dogs are (for instance social or solitaire, aggressive or friendly). After this, it becomes possible to compare friendly cats with friendly dogs, and aggressive cats with aggressive dogs - which in turn enhances the insight into the general differences between cats and dogs.

\subsection{Three political acts.}

The core idea that lays the foundation of this dissertation is the recognition of the three discursive dimensions - ideological, social, and presentational-at work within political style, as explained in Chapters 2 and 4. Though characterizing ideological thought as part of discourse is broadly accepted,, ideas/ideologies themselves are not regularly granted a separate dimension within discourse. Mostly, they are seen as being materialized in discourse and therefore lacking any immanent existence, as this would add content or truth to ideas and thus place them outside discourse. For this reason, Althusser restricts ideology to its materialization in discourse use (Althusser, 197//2008). This dissertation, however, claims otherwise. My research finds that although ideas exist only within discourse, they materialize according to their own logic-a logic that originates in the discourse structure, as termed by De Saussure (1916/20I5). This, then, does not add pre-given content or truth to an idea.

This ideational logic exists immanently from the other two logics, as the three logics contradict each other to some extent. In this contradiction, an excess of meaning is present (more elaborately, see Chapter 2). Acknowledging the structural character of the ideational dimension within discourse can help to clarify certain discussions on populism, such as the emotional dispute between Laclau and Žižek (Laclau, 2006; Žižek, 2006b, 2006a). The two scholars discussed populism, based on theories of (amongst others) Marx, Hegel, and Lacan. The discussion evidently goes beyond the linguistic scope of this dissertation. Nevertheless, relating the controversy to linguistics helps to understand what is at stake. Linguistically 
speaking, Laclau and Žižek refer to the question of whether or not the discourse used to create a populist equivalential chain (in the social and presentational dimension) is already pre-structured in the discourse system (ideational dimension) or not. According to Žižek, capitalism is such a super structure and a populist struggle (in discourse use) will never structurally change capitalism as a system, as the ideational dimension restricts the discourse used to what is acceptable within the capitalist system. Laclau contests this; he asserts that Žižek misunderstands Lacan and that he adds the context-dependent content of capitalism to the purely formal Lacanian Real (Laclau, 2005a, p. 234).

Laclau states that the construction of the people is a purely performative act, however, the linguistic analysis in this dissertation asserts that Žižek has a point: a people is not constructed out of nothing, but out of existing dominant framings within discourse (Žižek, 2006a). The content of these dominant framings maybe context dependent, but the logic which they are based on is structural (see Chapters 2 and 4); it is the logic that accepts words as universal truths rather than as framings. Unconsciously, people often use the frames that they want to fight, and if this happens this fight is doomed to fail. For instance, a person can argue that the country needs its tax, and that "tax relief" is not a good idea. This argument, however, contains an internal contradiction because the word relief already frames tax as something negative. Using the word tax relief in a pro-tax argument makes it less persuasive (Lakoff, 2004). Only through revealing that dominant framings within the ideational dimension of discourse are in fact framings rather than truths, can the system be made (somewhat) open for change (see Chapter 2).

This entails that, besides the rhetorical construction of an external enemy-which is the discursive (presentational) act of populism - another discursive act is needed in politics: the deconstruction of an internal enemy. This enemy consists of our own thoughts and language, built up from dominant framings and contradicting our own political goals. This is not a populist act, but a pluralist one, as it is grounded in the recognition that a subject is not one or whole but split and constructed through discourse. The language structure underlying populism, elitism, and pluralism shows that pluralism is grounded in the split nature of the subject and society, whereas both populism and elitism express an imaginary wholeness of the subject and society (see Figure 9.3). So, in order to change a society, politics necessarily comprises a pluralist act, besides the Laclauian populist act.

If there is a pluralist and a populist act needed in politics, it is only logical that an elitist act is also required. The required elitist act is that people are not in politics for their own gain, but 
instead to help others. Although elitism is often critiqued for being the opposite, the intention of elitism is altruistic; people who have a better position in society are obliged to help the less fortunate by working "for the greater good." This good intention is an underestimated aspect of elitism. The altruistic act of elitism-people helping other people-is a third unmissable political act, because it is the only way to achieve peace between individuals and groups of people after the populists and pluralist fights have been fought. Hence, all three political styles are needed in a democracy; populism as much as elitism and pluralism.

\section{Contribution to the Political Metaphor Concept}

Metaphor is central to the populist phenomenon, even more profoundly than I had expected when starting this project. It was the salient use of metaphor by the populist politician Geert Wilders-employing terms such as "a tsunami of refugees" and "a headrag tax"- that had sparked my interest in the topic in the first place (Schoor, 20I I). This question had mainly concerned the manifestation level of language. However, in the process of developing a political style theory, it showed that metaphor plays an important part in populism on all three of Greimas' (1970/1987) levels of language: the manifestation level, the surface semiolinguistic structure, and the deep semio-linguistic structure of language.

On the manifestation level of language, the speech analysis performed in Chapter 8 elucidates the role of metaphor in populism and other political styles. The three dimensions play a part here in terms of the purpose of the language used. These purposes have repercussions for the types of metaphors used by populists. For instance, the analysis in Chapter 8 shows that the POLITICS IS A FIGHT metaphor is used differently in populism than in elitism and pluralism. In the elitist speech, politics is competitive game in which the winner takes all. In the pluralist speech, politics is a contest, a challenge in which all people work together and win. In the populist speech, politics is a fully-fledged war. These metaphors precisely express the core values of elitism, pluralism, and populism. They can, for this reason, be regarded as typical for these styles.

On the surface structure level of language, or the populist narrative, populist politicians are themselves a main metaphor for the people. Populists very explicitly do not present themselves as politicians: they act metaphorically as the people themselves, speaking directly on their behalf. With their performance, populists make their version of the people 
metaphorically present in the political realm. This demonstrates the necessity of the entire political performance- and not just the ideas it expresses- to a fuller comprehension of populism.

Regarding the deep structure of language, the core structure underlying populism traces back to the three main linguistic oppositions explained in chapters 2 and 4 . Here, metaphor as linguistic principal is central to populism: it uses direct (metaphorical) identification with the people, instead of the adjacent (metonymic) relationship between people used by non-populists.

The relation between language, populism, and metaphor offers a new angle from which to analyze the role of metaphor in political framing. Lakoff emphasized the importance of metaphor for framing (Lakoff, 1995, 2004, 2014). According to Lakoff, Republicans think of the country as a family with an authoritative father, whereas Democrats conceptualize it as a family with nurturing parents (Lakoff, 2004, p. 6). The analyses in this dissertation suggest that Lakoffs identification of two main metaphorical family frames in US politics requires elaboration. Speech analysis in Chapter 3 shows that a democrat such as Bernie Sanders often speaks of the people as "brothers and sisters". Hence, at least a third familyrelated metaphorical frame is being used in US politics; that of the children as equals with absent parents. There are many observable variants of this scenario, visible in common phrases such as the brotherhood of men, and the brothers and sisters of the revolution. Another variant is the orphans-frame: in the Netherlands, politician Pim Fortuyn called the people orphans, ones who had done away with their parents in the sixties and were now in need of a father and mother (Fortuyn, 2002). More family related political frames are identified by Augé. She showed that English, Spanish, and French media not only used the nurturing mother as a political frame; also the strict mother and victimized mother regularly occurred (Augé, 2019). Musolff also identified two family metaphors in European media: alongside the usual children-parent metaphor scenario, he also defined a marriage-divorce metaphor (Musolff, 2016, p. 3I). The variety of family metaphors is not surprising; using metaphors is a creative process, and there is always the possibility of reframing the family in yet another way. This entails that, at the manifestation level, it is difficult — if not impossible — to link metaphor usage to political style. However, linking metaphors to this dissertation's framework allows us to discern patterns in metaphor use at another level of abstraction.

For instance, it is apt to place the Republican authoritarian father at the right side of the horseshoe/left-right triangle (Figure 9.I), and the Democratic nurturing parents in the 
center, below the triangle of Figure 9.I. The rebellious children can be placed at the left side, as well as the victimized mother, and so forth. Though there is an endless possibility of new metaphors for expressing political framings, some metaphor scenarios are typical for a certain frame, which makes them unsuitable for use in other frames. This is, for instance, the case with the war metaphor scenario, as demonstrated in Chapter 8. All political frames allow the depiction of politics as a fight. However, depicting it as a war is not possible in a pluralist or elitist frame, as its typical populist view of politics directly contradicts these styles.

Lastly, as described in Chapters 2 and 8, this dissertation points at a theoretical connection between three metaphor purposes and the three dimensions of political style. Style and metaphor theories suggest relationships between populism, pathos, and emotionbased metaphor, between elitism, ethos, and strategy-based metaphor, and between pluralism, logos, and ratio-based metaphor, as explained in Chapter 8. However, the link does not reveal itself candidly in political discourse - which always contains all three types of metaphor-as the three dimensions are inseparable. However, the main purposes of the three speeches analyzed in Chapter 8 do in fact reflect this pattern. The amount of speeches analyzed is too limited to allow us to draw conclusions based on this pattern; more analyses are needed in order to explore this further.

\section{Contribution to Political Analysis Methods}

The analysis tool developed here is an improvement upon existing tools, as it is based on a Satori-proof answer to the question of whether or not something is populist (elitist, pluralist), but at the same time avoids creating contested cases. Sartori demanded social research categories that would generate clear yes or no answers (Sartori, 1970, 1991). The logic of the tool never pits populism entirely against pluralism or elitism; precisely in its overlap with one style is populism the opposite of another. This results in a stepwise yes-no procedure that can be used to define a political style: is a speech fragment populist or not? If not: is this fragment elitist or not? If not: it is pluralist. If fragments cannot be identified as having one style-even with clear categories, political discourse is not always unambiguous - they can at least be identified as having one anti-style, which consists of the shared features of two other styles. 
The ability to generate yes/no categories that align with the common-sense understanding of populism is of great value for social research into populism. One might argue the merit of existent yes/no categories, such as those based on two broadly accepted minimal definitions of populism by Mudde (2017) and the Essex School (e.g., Stavrakakis \& Katsambekis, 20I4), respectively. Indeed, separate from each other, they do work; however, when considered together they leave many contested cases, such as Jeremy Corbyn, who is considered populist according to one minimal definition, but not the other (see Chapter 4, section I). The populism definition in this dissertation helps to assess these contested cases, as it precisely shows how a style is assembled. For instance, Corbyn displays a mixed populistpluralist style, fully populist in the social dimension but only partly in the ideational and presentational dimensions. Using clear yes/no categories does not entail that someone is either populist or not: instead, the layered form of the model allows forms of populism that are mixed with elitism or pluralism.

Other scholars have constrained the populist category in their construction of yes-no categories. For instance, Pappas (2016) defines populism as “democratic illiberalism," as opposed to liberalism. This yes-no category is indeed relevant in today's European democratic contexts. Nevertheless, Papas creates a large group of newly contested cases by denying the populist label to all Northern liberal populist parties, such as the Dutch Freedom Party and the Danish People's Party. This goes against the common-sense meaning of populism, in which these parties are regarded as populist (Moffitt, 20I7). In the framework presented in this dissertation, democratic illiberalism' is more broadly identified as antipluralism, which is mixed populism-elitism, while the northern liberal populists such as Geert Wilders are regarded as fully populist (see Chapter 5). This assessment is better in line with other definitions of populism.

Apart from the elimination of contested cases, the PEP index holds the advantage over other analysis methods that it is capable of assessing all political styles-populist as well as mainstream. It does not ask the question what is populist, it asks what is, in this specific political context, relatively populist, elitist, or pluralist? Together, the three styles cover all possibilities in a logical field of what style a political performance can have. 


\section{Contribution to the Literature on Current Politics}

This dissertation also contributes to the understanding of recent political developments, most prominently the current global rise of populism (Moffitt, 2016; Norris \& Inglehart, 2019). The speeches analyzed in the context of this dissertation may only provide small contributions; nevertheless, little pieces can be of great help in gaining insight into this complex political situation. In this section, I summarize a few insights gathered from the 67 speech analyses conducted.

In the United States, the analysis of speeches of Trump, Sanders, Clinton, and Obama have illuminated both differences and similarities between the politicians. Whereas Sanders has a mixed populist-pluralist style, Trump has a full populist style. Clinton has a mixed pluralist-elitist style, and Obama's style falls between Clinton and Sanders; he is fully pluralist. A closer look at Clinton and Sanders shows that, despite both being Democrats, their difference in style is larger than that of Sanders and Trump. The two Democrats mostly differ in their conception of politics: one seeing it as conflict, the other seeing it as collaboration.

In addition to this, I analyzed Trump's style in speeches spread over a three-year timespan, which made it possible to evaluate how his style developed from populist to mixed populist-elitist. By analyzing his style in comparison to similar mixed populist-elitist stylesBoris Johnson in the UK and Thierry Baudet in the Netherlands-I was able to illuminate how elitist elements are integrated into a populist discourse. This style combination had hardly been explored until now.

While Trump's style was predominantly populist before he was elected president of the US in 2016, his speeches delivered in 2017 and 2018 show a slow movement toward elitism. As president, Trump continues to create an internal (populist) frontier within American society. However, the opposition is no longer between the people and the elite and immigrants; the new divide is between the real people (together with the real elite) and the bad elite and immigrants. This shift allows him to embrace his elite role as president while remaining part of the real people.

In the UK, Boris Johnson's political style between 2015 and 2017 shows two changes: one from mixed elitism-pluralism to full anti-pluralism, and one from elitism to populism and back. The populist move can be interpreted in light of the polarizing effect of the referendum, whereas the movement toward anti-pluralism can partly be understood as 
strategically-rhetorically motivated: within the ongoing Brexit debate, it is much more persuasive to state that the (non-pluralist) people voted as one for Brexit than that just over half of the people voted for Brexit. Besides, the analysis shows that Johnson's presentational style before Brexit was more pluralist than his ideas and that the elitist-populist style is more internally coherent; the separate styles of the dimensions come closer together in 2017 than in 2015 and 2016.

In the Netherlands, Thierry Baudet has consistently held a mixed populist-elitist style, combining a plain populist message with an elite, intellectual image. The style combines well with his nationalist and nativist message. Moreover, it has the strategic benefit of positioning him advantageously in the political field: different from both mainstream politicians and the dominant populist player in the Netherlands, Geert Wilders.

Lastly, a comparison of a fully populist speech with both fully elitist and pluralist speeches has contributed to the insight into the various metaphors used in different political styles. The analysis shows that simply counting the number of references to the people is insufficient for measuring populism in political text or talk. Van Leeuwen (2019) showed already that grammatical differences matter for the people centrism in a text; additionally, this dissertation shows that metaphorical differences can result in a completely different style. Hence, it is the way in which references to the people are made, that distinguishes populism from other political styles.

The conducted speech analyses can be complemented with numerous new analyses, ones that can be compared with the previously analyzed speeches. This provides ample opportunities for international political comparisons. A few are already underway, such as an analysis of Johnson's political style before, during, and after the Brexit referendum in comparison with Jeremy Corbyn's and Nigel Farage's style (Schoor, 2019). Only Farage's style has remained somewhat over the course of the Brexit campaign; both Corbyn's and Johnson's show major style shifts. Also, the differences between populist and non-populist styles in current Dutch politics are under analysis, by complementing the style analyses of right- and left wing populists in this dissertation with analyses of mainstream politicians in the Netherlands. 


\section{The Politics of Style}

The relevance of political style has shown itself through the analyses in this dissertation. The layered expressions of style enable politicians to express much more than a simple statement or opinion in the limited timeslot of a media presentation. They express not only what they stand for, but also who they are, and who they fight for. The concepts developed in this dissertation provide a handle for analyzing the entire performance of politicians in a comprehensive way.

The performed analyses show that most politicians express a coherent style (or antistyle); a style in which all parts contribute to their political message. More analyses are needed in order to gain a deeper insight into the meaning of political style. For instance; the relation between populism-elitism-pluralism and right-left-center politics; the relation between political role and style; the relation between political circumstances, such as referendums and elections, and style. All these questions can be further investigated with the tools developed in this dissertation. With the developed concepts and analysis tool, this dissertation has leveled the playing field of political style analysis. Now, it is time to explore the field even more thoroughly. 



\section{APPENDICES}




\title{
Appendix A: Speech List
}

\author{
Analyzed Speeches in PEP-index 2.0
}

\section{The USA:}

I. Obama, B. “The Democratic Convention Speech,” Philadelphia, July 27, 2016. https://www.c-span.org/video/?4I 2847-I0I/president-obama-remarks-democraticnational-convention

2. Obama, B. "Press conference," Canada, June 29, 2016. https://obamawhitehouse.archives.gov/photos-and-video/video/2016/06/29/presidentobama-participates-trilateral-press-conference (partially analyzed)

3. Sanders, B. "The Washington Square Rally,” New York, April I3, 2016. https://www.youtube.com/watch?v=s9NjVjG2lql

4. Sanders, B. “The Penn State Rally,” Pennsylvania, April 19, 2016. https://www.cspan.org/video/?408383-I/bernie-sanders-campaign-rally-university-park-pennsylvania

5. Clinton, H. "Manhattan Rally,” New York, April 18, 20I6. https://www.cspan.org/video/?408350-I/hillary-clinton-getoutthevote-rally

6. Clinton, H. "Scranton Rally," Scranton PA, April 22, 2016. https://www.cspan.org/video/?408560-I/hillary-clinton-campaign-event-scranton-pennsylvania

7. Trump, D. “The Buffalo Rally,” Buffalo, April 18, 2016. https://www.cspan.org/video/?40835 I-I/donald-trump-campaign-rally-buffalo-new-york

8. Trump, D. “The Wilkes-Barre Rally,” Wilkes-Barre, April 25, 2016. https://www.cspan.org/video/?408686-I/donald-trump-campaign-rally-wilkesbarre-pennsylvania

9. Trump, D. “The Pensacola Rally,” Pensacola, FL, December 8, 20I7, video, https://www.c-span.org/video/?43819I-I/president-trump-holds-rally-pensacola-florida;

10. Trump, D. “The Minnesota Rally,” Rochester, MN, June 20, 2018, video, https://www.cspan.org/video/?452500-I/president-trump-campaigns-republicans-rochester-minnesota.

\section{The UK:}

I I. Farage, N. "The 2015 UKIP Conference Speech” September 25, 20I5. https://www.cspan.org/video/?328350-I/uk-independence-party-conference-nigel-farage-speech

I2. Farage, N. “The 2016 Peterborough Brexit Campaign Speech,” March 17, 2016. https://www.youtube.com/watch?v=RDdDS2NZOI4 
I3. Farage, N. “The 2017 Conservative Political Activism Conference," February 24, 2017. https://www.c-span.org/video/?424395-4/nigel-farage-2017-conservative-political-actionconference

14. Johnson, B. “The 2015 Conservative Party Conference Speech,” Manchester, October 6, 2015, video, https://www.youtube.com/watch?v=j2jJQumLfg8

I5. Johnson, B. “The 2016 Brexit Campaign Speech,” May 9, 2016. https://www.youtube.com/watch?v=4ViQNeZRK3w

16. Johnson, B. “The 2017 Conservative Party Conference Speech,” October 3, 2017. https://www.youtube.com/watch?v=YMKURiCcUNI

17. Corbyn, J. “The 2015 Labor Conference Speech,” September 29, 2015. https://www.youtube.com/watch?v=qHGEnYCh/YM

18. Corbyn, J. “The 2016 Brexit Remain campaign,” April 14, 2016. https://www.youtube.com/watch? $v=t 6 a 2 s E c-B W E$

19. Corbyn, J. “The 2017 Labor Conference Speech,” September 27, 2017. https://www.youtube.com/watch?v=bKpCwTEJ77A

\section{The Netherlands:}

20. Wilders, G. "Parliamentary Speech,” The Hague, September 2I, 2016. https://www.youtube.com/watch?v=m-dq2xy80cs

21. Wilders, G. “ENF Congress Speech,” Koblenz, January 21, 2017. https://www.youtube.com/watch?v=QhEAB9dyUpU

22. Roemer, E. “The Party Congressional Speech,” January I4, 2017. https://www.sp.nl/nieuws/2017/01/emile-roemer-we-maken-sp-groot-en-rutte-klein

23. Roemer, E. "Final Election Television Debate," March I4 2017. https://www.youtube.com/watch?v=jTQLq_9NIrU

24. Baudet, T. “The Founding Speech,” Amsterdam, January 14, 2017. https://www.youtube.com/watch?time_continue=I\&v=JvIRApuld-o

25. Baudet, T. “The Rotterdam Rally,” Rotterdam, March 9, 2017. https://www.youtube.com/watch?v=EuPSQOltuxl

26. Baudet, T. “The Maiden Speech,” The Hague, March 28, 2017. https://zoek.officielebekendmakingen.nl/h-tk-201620I7-60-9.html 
27. Baudet, T. “The Venlo Rally,” Venlo, June II, 20I8, video, https://www.facebook.com/forumvoordemocratie/videos/fvd-invenlo/I58450764834/607/

28. Baudet, T. “The Senate Victory Speech,” March 20, 2019, video, https://www.youtube.com/watch?v= ABtSOHdI2s

29. Rutte, M. "Debat over de regeringsverklaring 2012 deel I", The Hague, November I3, 2012, https://zoek.officielebekendmakingen.nl/h-tk-20I220I3-22-3.html

30. Rutte, M. “Debat over de regeringsverklaring 2012 deel 2", The Hague, November I4, 2012, https://zoek.officielebekendmakingen.nl/h-tk-20I220I3-22-6.html

3I. Zandt, P. “Debat over de regeringsverklaring 1946, deel I ”, The Hague, July 9, 1946 https://repository.overheid.nl/frbr/sgd//9461/0000074966/I/pdf/SGD_1946I_00000I5.pdf

\section{Analyzed speeches in PEP-index 0}

\section{The Netherlands:}

32. Wagenaar, G. (CPN), “Debat over de regeringsverklaring 1946, deel I”, The Hague, July 9, 1946. P. 56 onwards. https://repository.overheid.nl/frbr/sgd//9461/0000074966/I/pdf/SGD_19461_00000I5.pdf

33. Wagenaar, G. (CPN), “Debat over de regeringsverklaring 1946, deel 2”, The Hague, July 10, 1946. p. 82 onwards.

https://repository.overheid.nl/frbr/sgd//9461/0000074967/I/pdf/SGD_19461_00000I6.pdf

34. Wagenaar, G. (CPN), “Interpellatiedebat onrust uitzending dienstplichtigen naar Indonesie", The Hague, September, 25, 1946. p.38 onwards.

35. Van der Goes van Naters, M. (PvdA) “Debat over de regeringsverklaring 1946. Deel I”, The Hague, July 9, 1946. P 58 onwards. https://repository.overheid.nl/frbr/sgd//9461/0000074966/I/pdf/SGD_1946I_00000I5.pdf

36. Van der Goes van Naters, M. (PvdA) “Debat over de regeringsverklaring 1946, deel 2”, The Hague, July 10, 1946, p. 84 onwards. https://repository.overheid.nl/frbr/sgd//946I/0000074967/I/pdf/SGD_1946I_00000 I6.pdf

37. Schouten, J.(ARP). ) “Debat over de regeringsverklaring 1946, deel I”, The Hague, July 9 , 1946. P. 48 onwards.

https://repository.overheid.nl/frbr/sgd//9461/0000074966/I/pdf/SGD_1946I_00000I5.pdf 
38. Schouten, J.(ARP). ) “Debat over de regeringsverklaring 1946, deel 2”, The Hague, July 10, 1946. P. 77 onwards. https://repository.overheid.nl/frbr/sgd/19461/0000074967/I/pdf/SGD_19461_0000016.pdf

39. Beel, L. (KVP). “Regeeringsverklaring 1946,”, The Hague, July 05, 1946 p. 45 onwards. https://repository.overheid.nl/frbr/sgd/I9461/0000074965///pdf/SGD_1946I_00000I4.pdf

40. Beel, L. (KVP). “Debat over de regeringsverklaring 1946, deel 2”, The Hague, July 9, 1946. P. 74 onwards https://repository.overheid.nl/frbr/sgd//9461/0000074966/I/pdf/SGD_19461_0000016.pdf

4I. Koekoek, H. (BP). “Debat over de regeringsverklaring I97I, deel I”, The Hague, August 4, 197I. P. 213 onwards.

https://repository.overheid.nl/frbr/sgd/I97I/0000222I50/I/pdf/SGD_197I_0000I25.pdf;

42. Koekoek, H. (BP). “Debat over de regeringsverklaring 197I, deel 2”, The Hague, August 5, 1971, p 253 onwards https://repository.overheid.nl/frbr/sgd/I97I/000022215I/I/pdf/SGD_197I_0000126.pdf

43. Den Uyl, J. (PvdA). “Debat over de regeringsverklaring I97I, deel I”, The Hague, August 4, 197I, p I54 onwards https://repository.overheid.nl/frbr/sgd//971/0000222I50/I/pdf/SGD_1971_0000125.pdf;

44. Den Uyl, J. (PvdA). “Debat over de regeringsverklaring 197I, deel 2”, The Hague, August 5, 1971, p 236 onwards https://repository.overheid.nl/frbr/sgd//971/000022215I/I/pdf/SGD_1971_0000126.pdf

45. Van Mierlo, H. (D66). "Debat over de regeringsverklaring 197I, deel I”, The Hague, August 4, I97I, p. 160 onwards https://repository.overheid.nl/frbr/sgd//971/0000222/50/I/pdf/SGD_197|_0000125.pdf

46. Van Mierlo, H. (D66). "Debat over de regeringsverklaring 197I, deel 2”, The Hague, August 5, 197I, p. 239 onwards https://repository.overheid.nl/frbr/sgd/I971/0000222I5I/I/pdf/SGD_197I_0000126.pdf

47. Wiegel H. (VVD). "Debat over de regeringsverklaring 197I, deel I”, The Hague, August 4, 197I, p. 172 onwards https://repository.overheid.nl/frbr/sgd//971/0000222/50/I/pdf/SGD_197I_0000125.pdf

48. Wiegel H. (VVD). “Debat over de regeringsverklaring 1971, deel 2”, The Hague, August 5, 197I, p.243 onwards https://repository.overheid.nl/frbr/sgd//971/000022215I/I/pdf/SGD_1971_0000126.pdf

49. Biesheuvel, B. (ARP). “Regeringsverklaring 197I”, The Hague, August 3, I97I, p. 138 onwards https://repository.overheid.nl/frbr/sgd/I97I/0000222/49/I/pdf/SGD_197I_0000124.pdf 
50. Biesheuvel, B. (ARP). "Debat over de regeringsverklaring 197I, deel 2", The Hague, August 5, 197I, p. 218 onwards https://repository.overheid.nl/frbr/sgd//971/0000222I5I/I/pdf/SGD_197I_0000126.pdf

5I. Bolkestein, F. (VVD) “Debat over de regeringsverklaring 1994, deel I”, The Hague, August 31, 1994, p. 5836 onwards https://repository.overheid.nl/frbr/sgd/I9931994/0000003679/I/pdf/SGD_19931994_0001090.pdf;

52. Heerma, E. (CDA) “Debat over de regeringsverklaring 1994, deel I”, The Hague, August 31 , 1994, p. 5816 onwards https://repository.overheid.nl/frbr/sgd//9931994/0000003679/I/pdf/SGD_19931994_0001090.pdf;

53. Kok, W. (PvdA) “Regeringsverkalring 1994”, The Hague, August 31, 1994, p. 5805 onwards. https://repository.overheid.nl/frbr/sgd/I9931994/0000003679/I/pdf/SGD_19931994_0001090.pdf;

54. Kok, W. (PvdA) “Debat over de regeringsverklaring 1994, deel 2”, The Hague, September I, 1994, p. 5836 onwards https://repository.overheid.nl/frbr/sgd/I9931994/0000003680/I/pdf/SGD_19931994_0001091.pdf

55. Rosemuller, P (GL). “Debat over de regeringsverklaring 1994, deel I”, The Hague, August 31, 1994, p. 5845 onwards https://repository.overheid.nl/frbr/sgd//9931994/0000003679/I/pdf/SGD_19931994_0001090.pdf;

56. Marijnissen, J. (SP). “Debat over de regeringsverklaring 1994, deel I”, The Hague, August 3I, 1994, p. 5865 onwards https://repository.overheid.nl/frbr/sgd//9931994/0000003679/I/pdf/SGD_19931994_0001090.pdf;

57. Marijnissen, J. (SP). “Debat over de regeringsverklaring 1994, deel 2”, The Hague, September I, 1994, p. 5923 onwards https://repository.overheid.nl/frbr/sgd/I9931994/0000003680/I/pdf/SGD_19931994_0001091.pdf

58. Marijnissen, J. (SP). “Algemene Politieke Beschouwingen 1994”, The Hague, September 2I, 1994. P 94 onwards.

https://repository.overheid.nl/frbr/sgd//9941995/0000000297/I/pdf/SGD_1994/995_000028I.pdf

59. Wilders, G. (PVV). "Debat over de regeringsverklaring 2012, deel I", The Hague, November 13, 2012, p.07 onwards. https://zoek.officielebekendmakingen.nl/h-tk-20I220I3-22-3.html 60. Wilders, G. (PVV). “Debat over de regeringsverklaring 2012, deel 2”, The Hague, November 14, 2012, P 63 onwards. https://zoek.officielebekendmakingen.nl/h-tk-20122013$\underline{22-6 . h t m l}$ 
6I. Roemer, E. (SP) “Debat over de regeringsverklaring 2012, deel I”, The Hague, November 13, 2012, p. 27 onwards. https://zoek.officielebekendmakingen.nl/h-tk20I220I3-22-3.html

62. Roemer, E. (SP) “Debat over de regeringsverklaring 2012, deel 2”, The Hague, November 14, 2012, p. 64 onwards. https://zoek.officielebekendmakingen.nl/h-tk20122013-22-6.html

63. Roemer, E. (SP) “Verslag van de Informateurs 20I2, deel 2”, The Hague, Oktober 3I, 2012 p. 4 I onwards https://zoek.officielebekendmakingen.nl/h-tk-20122013-I7-6.html

64. Pechtold, A. (D66) “Debat over de regeringsverklaring 2012, deel I”, The Hague, November 13, 2012, p. 5 I onwards. https://zoek.officielebekendmakingen.nl/h-tk20122013-22-3.html

65. Samson (PvdA) "Verslag van de Informateurs 2012, deel I”, The Hague, Oktober 3I, 2012 p. 18 onwards. https://zoek.officielebekendmakingen.nl/h-tk-20I220I3-I7-2.html

66. Samson (PvdA) "Debat over de regeringsverklaring 20I2, deel I", The Hague, November 13, 20I2, p. 30 onwards. https://zoek.officielebekendmakingen.nl/h-tk-20I220I3-22$\underline{3 . h t m l}$

67. Samson (PvdA) “Debat over de regeringsverklaring 20I2, deel 2", The Hague, November 13, 2012 , p. 66 onwards. https://zoek.officielebekendmakingen.nl/h-tk-20I220I3-226.html 


\section{Appendix B: Subscores}

Sub-scores of the analyzed speeches in PEP-index 2

Elements:

I - The people;

2 - The elite;

3 - Democracy/government;

4 - Politics; and

5 - The political context.

Dimensions:

I - Ideational;

S - Social; and

P - Presentational.

Scores:

po $=$ populism $\quad$ poel $=$ mixed populism-elitism

el = elitism $\quad$ elpl $=$ mixed elitism-pluralism

$\mathrm{pl}=$ pluralism $\quad$ popl $=$ mixed populism-pluralism

$\mathrm{X}-\mathrm{Y}$ scores: the total and sub scores are converted into positions on a $\mathrm{X}-\mathrm{Y}$ isosceles triangular field. The triangle has Populism, Elitism, and Pluralism at its corners, with:

Populism: $\quad Y=+86,6$ and $X=+100$

Elitism: $\quad Y=+86,6$ and $X=-100$

Pluralism: $\quad \mathrm{Y}=-86,6$ and $\mathrm{X}=0$ 


\section{The USA:}

\begin{tabular}{|c|c|c|c|c|c|c|c|c|c|c|}
\hline \multicolumn{11}{|c|}{ Obama, 20I6, speech I } \\
\hline \multirow{2}{*}{$\begin{array}{l}\text { Dimensions } \\
\text { Total score }\end{array}$} & \multirow{2}{*}{\multicolumn{5}{|c|}{$\begin{array}{l}\text { Elements } \\
\text { pluralist }\end{array}$}} & \multicolumn{3}{|c|}{ Styles (\%) } & \multicolumn{2}{|c|}{ X-Y position } \\
\hline & & & & & & $13 \%$ & $7 \%$ & $80 \%$ & +7 & -52 \\
\hline Sub-scores & $\mathrm{I}$ & 2 & 3 & 4 & 5 & po & el & $\mathrm{pl}$ & $\mathrm{X}$ & $\mathrm{Y}$ \\
\hline I Ideational & $\mathrm{pl}$ & elpl & $\mathrm{pl}$ & popl & $\mathrm{pl}$ & $10 \%$ & $10 \%$ & $80 \%$ & 0 & $-51,9$ \\
\hline S Social & popl & $\mathrm{pl}$ & popl & $\mathrm{pl}$ & $\mathrm{pl}$ & $20 \%$ & & $80 \%$ & 0 & $-51,9$ \\
\hline P Presentational & popl & $\mathrm{pl}$ & $\mathrm{pl}$ & $\mathrm{pl}$ & elpl & $10 \%$ & $10 \%$ & $80 \%$ & 20 & $-51,9$ \\
\hline
\end{tabular}

Table BI

\begin{tabular}{|c|c|c|c|c|c|c|c|c|c|c|}
\hline \multicolumn{11}{|c|}{ Sanders, 20I6, speeches 3 en 4} \\
\hline \multirow{2}{*}{$\begin{array}{l}\text { Dimensions } \\
\text { Total score }\end{array}$} & \multirow{2}{*}{\multicolumn{5}{|c|}{$\begin{array}{l}\text { Elements } \\
\text { populist/pluralist }\end{array}$}} & \multicolumn{3}{|c|}{ Styles (\%) } & \multicolumn{2}{|c|}{$X-Y$ position } \\
\hline & & & & & & \multirow{2}{*}{$\begin{array}{l}57 \% \\
\text { po }\end{array}$} & \multirow[b]{2}{*}{ el } & \multirow{2}{*}{$\begin{array}{l}43 \% \\
\mathrm{pl}\end{array}$} & \multirow{2}{*}{$\begin{array}{l}+57 \\
\times\end{array}$} & \multirow{2}{*}{$\begin{array}{l}+12 \\
Y\end{array}$} \\
\hline Sub-scores & I & 2 & 3 & 4 & 5 & & & & & \\
\hline II Ideational & popl & po & popl & popl & popl & $60 \%$ & & $40 \%$ & +60 & +17 \\
\hline IS Social & popl & popl & $\mathrm{pl}$ & po & po & $60 \%$ & & $40 \%$ & +60 & +17 \\
\hline IP Presentational & popl & popl & $\mathrm{pl}$ & po & popl & $50 \%$ & & $50 \%$ & +50 & 0 \\
\hline
\end{tabular}

Table B2

\begin{tabular}{|c|c|c|c|c|c|c|c|c|c|c|c|}
\hline \multicolumn{12}{|c|}{ Clinton 2016, speeches 5 en 6} \\
\hline \multirow{3}{*}{$\begin{array}{l}\text { Dimensions } \\
\text { Total score } \\
\text { Sub-scores }\end{array}$} & \multirow{2}{*}{\multicolumn{5}{|c|}{$\begin{array}{l}\text { Elements } \\
\text { elitist/pluralist }\end{array}$}} & \multicolumn{4}{|c|}{ Styles (\%) } & \multicolumn{2}{|c|}{ X-Y position } \\
\hline & & & & & & \multirow[b]{2}{*}{ po } & \multirow{2}{*}{\begin{tabular}{|l|}
$43 \%$ \\
el \\
\end{tabular}} & \multirow{2}{*}{$\begin{array}{l}43 \% \\
\mathrm{pl}\end{array}$} & \multirow{2}{*}{\begin{tabular}{|l|}
$13 \%$ \\
con \\
\end{tabular}} & \multirow{2}{*}{$\begin{array}{l}-43,3 \\
X\end{array}$} & \multirow{2}{*}{$\begin{array}{l}+3,85 \\
Y\end{array}$} \\
\hline & I & 2 & 3 & 4 & 5 & & & & & & \\
\hline II Ideational & $\mathrm{pl}$ & el & elpl & elpl & elpl & & $50 \%$ & $50 \%$ & & -50 & 0 \\
\hline IS Social & con & el & $\mathrm{pl}$ & elpl & elpl & & $40 \%$ & $40 \%$ & $10 \%$ & -40 & $+5,8$ \\
\hline IP Presentational & con & elpl & elpl & elpl & elpl & & $40 \%$ & $40 \%$ & $10 \%$ & -40 & $+5,8$ \\
\hline
\end{tabular}

Table B3 


\begin{tabular}{|l|l|l|l|l|l|l|l|l|l|l|l|}
\hline Trump, 2016, speeches 7 en 8 \\
\hline Dimensions & \multicolumn{2}{l|}{ Elements } & \multicolumn{3}{l|}{ Styles (\%) } & \multicolumn{2}{l|}{ X-Y position } \\
\hline Total score & \multicolumn{2}{l}{ populist } & & & & $90 \%$ & $3 \%$ & $7 \%$ & +87 & +75 \\
\hline Sub-scores & I & 2 & 3 & 4 & 5 & po & el & pl & X & Y \\
\hline I Ideational & popl & po & po & po & po & $90 \%$ & & $10 \%$ & +90 & +69 \\
\hline S Social & po & poel & popl & po & po & $80 \%$ & $10 \%$ & $10 \%$ & +70 & +69 \\
\hline P Presentational & po & po & po & po & po & $100 \%$ & & & +100 & +87 \\
\hline
\end{tabular}

Table B4

\begin{tabular}{|c|c|c|c|c|c|c|c|c|c|c|}
\hline \multicolumn{11}{|c|}{ Trump 20I7, speech 9} \\
\hline \multirow{2}{*}{$\begin{array}{l}\text { Dimensions } \\
\text { Total score }\end{array}$} & \multirow{2}{*}{\multicolumn{5}{|c|}{$\begin{array}{l}\text { Elements } \\
\text { populist }\end{array}$}} & \multicolumn{3}{|c|}{ Styles (\%) } & \multicolumn{2}{|c|}{$\mathrm{X}-\mathrm{Y}$ position } \\
\hline & & & & & & $87 \%$ & $13 \%$ & & +73 & +87 \\
\hline Sub-scores & I & 2 & 3 & 4 & 5 & po & el & $\mathrm{pl}$ & $\mathrm{X}$ & $\mathrm{Y}$ \\
\hline II Ideational & po & po & po & po & poel & $90 \%$ & $10 \%$ & & +80 & +87 \\
\hline IS Social & po & poel & po & po & poel & $80 \%$ & $20 \%$ & & +60 & +87 \\
\hline IP Presentational & po & po & po & po & poel & $90 \%$ & $10 \%$ & & +80 & +87 \\
\hline
\end{tabular}

Table B5

\begin{tabular}{|c|c|c|c|c|c|c|c|c|c|c|}
\hline \multicolumn{11}{|c|}{ Trump 2018, speech 10} \\
\hline \multirow{2}{*}{\begin{tabular}{|l|} 
Dimensions \\
Total score
\end{tabular}} & \multicolumn{5}{|c|}{ Elements } & \multicolumn{3}{|c|}{ Styles (\%) } & \multicolumn{2}{|c|}{ X-Y position } \\
\hline & \multicolumn{5}{|c|}{ Populist/elitist } & $67 \%$ & $33 \%$ & & +33 & +87 \\
\hline Sub-scores & I & 2 & 3 & 4 & 5 & po & el & $\mathrm{pl}$ & $\mathrm{X}$ & $\mathrm{Y}$ \\
\hline II Ideational & po & poel & po & poel & poel & $70 \%$ & $30 \%$ & & +40 & +87 \\
\hline IS Social & po & poel & poel & poel & poel & $60 \%$ & $40 \%$ & & +20 & +87 \\
\hline IP Presentational & poel & poel & po & po & poel & $70 \%$ & $30 \%$ & & +40 & +87 \\
\hline
\end{tabular}

Table B6 


\section{The UK:}

\begin{tabular}{|c|c|c|c|c|c|c|c|c|c|c|}
\hline \multicolumn{11}{|c|}{ Farage 2015 , speech II } \\
\hline \multirow{2}{*}{$\begin{array}{l}\text { Dimensions } \\
\text { Total score }\end{array}$} & \multirow{2}{*}{\multicolumn{5}{|c|}{$\begin{array}{l}\text { Elements } \\
\text { populist }\end{array}$}} & \multicolumn{3}{|c|}{ Styles (\%) } & \multicolumn{2}{|c|}{ X-Y position } \\
\hline & & & & & & $80 \%$ & & $20 \%$ & +80 & +52 \\
\hline Sub-scores & I & 2 & 3 & 4 & 5 & po & el & $\mathrm{pl}$ & $\mathrm{X}$ & $\mathrm{Y}$ \\
\hline II Ideational & popl & po & po & popl & po & $80 \%$ & & $20 \%$ & +80 & +52 \\
\hline IS Social & popl & po & popl & po & po & $80 \%$ & & $20 \%$ & +80 & +52 \\
\hline IP Presentational & po & po & po & po & $\mathrm{pl}$ & $80 \%$ & & $20 \%$ & +80 & +52 \\
\hline
\end{tabular}

Table B7

\begin{tabular}{|c|c|c|c|c|c|c|c|c|c|c|}
\hline \multicolumn{11}{|c|}{ Farage 2016 , speech 12} \\
\hline \multirow{2}{*}{$\begin{array}{l}\text { Dimensions } \\
\text { Total score }\end{array}$} & \multirow{2}{*}{\multicolumn{5}{|c|}{\begin{tabular}{|l|} 
Elements \\
populist
\end{tabular}}} & \multicolumn{3}{|c|}{ Styles (\%) } & \multicolumn{2}{|c|}{ X-Y position } \\
\hline & & & & & & \multirow{2}{*}{$\begin{array}{l}87 \% \\
\text { po }\end{array}$} & \multirow[b]{2}{*}{ el } & \multirow{2}{*}{$\begin{array}{l}\mathrm{I} 3 \% \\
\mathrm{pl}\end{array}$} & \multirow{2}{*}{\begin{tabular}{|l|}
+87 \\
$X$ \\
\end{tabular}} & \multirow{2}{*}{\begin{tabular}{|l|}
+64 \\
$Y$
\end{tabular}} \\
\hline Sub-scores & I & 2 & 3 & 4 & 5 & & & & & \\
\hline II Ideational & popl & po & po & po & po & $90 \%$ & & $10 \%$ & +90 & +69 \\
\hline IS Social & po & po & po & po & po & $100 \%$ & & & +100 & +87 \\
\hline IP Presentational & popl & popl & po & po & popl & $70 \%$ & & $30 \%$ & +70 & +35 \\
\hline
\end{tabular}

Table B8

\begin{tabular}{|c|c|c|c|c|c|c|c|c|c|c|}
\hline \multicolumn{11}{|c|}{ Farage 2017 , speech 13} \\
\hline \multirow{2}{*}{$\begin{array}{l}\text { Dimensions } \\
\text { Total score }\end{array}$} & \multirow{2}{*}{\multicolumn{5}{|c|}{$\begin{array}{l}\text { Elements } \\
\text { populist }\end{array}$}} & \multicolumn{3}{|c|}{ Styles (\%) } & \multicolumn{2}{|c|}{$\mathrm{X}-\mathrm{Y}$ position } \\
\hline & & & & & & $100 \%$ & & & +100 & +87 \\
\hline Sub-scores & I & 2 & 3 & 4 & 5 & po & el & $\mathrm{pl}$ & $\mathrm{X}$ & $\mathrm{Y}$ \\
\hline II Ideational & po & po & po & po & po & $100 \%$ & & & +100 & +87 \\
\hline IS Social & po & po & po & po & po & $100 \%$ & & & +100 & +87 \\
\hline IP Presentational & po & po & po & po & po & $100 \%$ & & & +100 & +87 \\
\hline
\end{tabular}

Table B9 


\begin{tabular}{|c|c|c|c|c|c|c|c|c|c|c|}
\hline \multicolumn{11}{|c|}{ Johnson 2015, speech 14} \\
\hline Dimensions & \multicolumn{5}{|c|}{ Elements } & \multicolumn{3}{|c|}{ Styles (\%) } & \multicolumn{2}{|c|}{$\mathrm{X}-\mathrm{Y}$ position } \\
\hline Total score & \multicolumn{5}{|c|}{ Elitist } & $23 \%$ & $57 \%$ & $20 \%$ & -33 & +52 \\
\hline Sub-scores & I & 2 & 3 & 4 & 5 & po & el & $\mathrm{pl}$ & $X$ & $\mathrm{Y}$ \\
\hline II Ideational & elpl & poel & poel & poel & el & $30 \%$ & $60 \%$ & $10 \%$ & -30 & +69 \\
\hline IS Social & elpl & elpl & el & poel & el & $10 \%$ & $70 \%$ & $20 \%$ & -60 & +52 \\
\hline IP Presentational & poel & elpl & $\mathrm{pl}$ & poel & poel & $30 \%$ & $40 \%$ & $30 \%$ & -10 & +35 \\
\hline
\end{tabular}

Table BI0

\begin{tabular}{|c|c|c|c|c|c|c|c|c|c|c|}
\hline \multicolumn{11}{|c|}{ Johnson 2016 , speech 15} \\
\hline Dimensions & \multicolumn{5}{|c|}{ Elements } & \multicolumn{3}{|c|}{ Styles (\%) } & \multicolumn{2}{|c|}{$\begin{array}{l}X-Y \\
\text { position }\end{array}$} \\
\hline Total score & \multicolumn{5}{|c|}{ Populist-elitist } & $63 \%$ & $30 \%$ & $7 \%$ & +33 & +75 \\
\hline Sub-scores & I & 2 & 3 & 4 & 5 & po & el & $\mathrm{pl}$ & $\mathrm{X}$ & $\mathrm{Y}$ \\
\hline II Ideational & poel & poel & poel & po & po & $80 \%$ & $15 \%$ & $5 \%$ & +40 & +87 \\
\hline IS Social & poel & poel & poel & po & poel & $60 \%$ & $40 \%$ & & +20 & +87 \\
\hline IP Presentational & poel & poel & popl & po & popl & $60 \%$ & $20 \%$ & $20 \%$ & +40 & +52 \\
\hline
\end{tabular}

Table BII

\begin{tabular}{|c|c|c|c|c|c|c|c|c|c|c|}
\hline \multicolumn{11}{|c|}{ Johnson 2017, speech 16} \\
\hline \multirow{3}{*}{$\begin{array}{l}\text { Dimensions } \\
\text { Total score } \\
\text { Sub-scores }\end{array}$} & \multirow{2}{*}{\multicolumn{5}{|c|}{$\begin{array}{l}\text { Elements } \\
\text { Elitist-populist }\end{array}$}} & \multicolumn{3}{|c|}{ Styles (\%) } & \multicolumn{2}{|c|}{$\mathrm{X}-\mathrm{Y}$ position } \\
\hline & & & & & & \multirow{2}{*}{\begin{tabular}{l|}
$30 \%$ \\
po
\end{tabular}} & \multirow{2}{*}{\begin{tabular}{|l|}
$70 \%$ \\
el
\end{tabular}} & \multirow[b]{2}{*}{$\mathrm{pl}$} & \multirow{2}{*}{$\begin{array}{l}-40 \\
x\end{array}$} & \multirow{2}{*}{$\begin{array}{l}+87 \\
Y\end{array}$} \\
\hline & I & 2 & 3 & 4 & 5 & & & & & \\
\hline II Ideational & el & poel & poel & poel & el & $30 \%$ & $70 \%$ & & -40 & +87 \\
\hline IS Social & el & el & poel & poel & el & $20 \%$ & $80 \%$ & & -60 & +87 \\
\hline IP Presentational & poel & el & poel & poel & poel & $40 \%$ & $60 \%$ & & -20 & +87 \\
\hline
\end{tabular}

Table BI2 


\begin{tabular}{|c|c|c|c|c|c|c|c|c|c|c|}
\hline \multicolumn{11}{|c|}{ Corbyn 2015, speech 17} \\
\hline \multirow{2}{*}{$\begin{array}{l}\text { Dimensions } \\
\text { Total score }\end{array}$} & \multirow{2}{*}{\multicolumn{5}{|c|}{\begin{tabular}{|l} 
Elements \\
Pluralist-populist
\end{tabular}}} & \multicolumn{3}{|c|}{ Styles (\%) } & \multicolumn{2}{|c|}{ X-Y position } \\
\hline & & & & & & \multirow{2}{*}{\begin{tabular}{|l|l|}
$37 \%$ \\
po
\end{tabular}} & \multirow{2}{*}{\multicolumn{2}{|c|}{\begin{tabular}{l|l|} 
& $63 \%$ \\
el & $\mathrm{pl}$
\end{tabular}}} & \multirow{2}{*}{$\begin{array}{l}+37 \\
X\end{array}$} & \multirow{2}{*}{\begin{tabular}{|l|}
-23 \\
$Y$ \\
\end{tabular}} \\
\hline Sub-scores & 1 & 2 & 3 & 4 & 5 & & & & & \\
\hline II Ideational & plpo & po & plpo & plpo & po & $70 \%$ & & $30 \%$ & +70 & +35 \\
\hline IS Social & $\mathrm{pl}$ & $\mathrm{pl}$ & $\mathrm{pl}$ & $\mathrm{pl}$ & po & $80 \%$ & & $20 \%$ & +20 & -52 \\
\hline IP Presentational & $\mathrm{pl}$ & $\mathrm{pl}$ & $\mathrm{pl}$ & plpo & plpo & $80 \%$ & & $20 \%$ & +20 & -52 \\
\hline
\end{tabular}

\section{Table BI3}

\begin{tabular}{|c|c|c|c|c|c|c|c|c|c|c|}
\hline \multicolumn{11}{|c|}{ Corbyn 2016 , speech 18} \\
\hline \multirow{3}{*}{$\begin{array}{l}\text { Dimensions } \\
\text { Total score } \\
\text { Sub }\end{array}$} & \multirow{2}{*}{\multicolumn{5}{|c|}{$\begin{array}{l}\text { Elements } \\
\text { Pluralist-populist }\end{array}$}} & \multicolumn{3}{|c|}{ Styles (\%) } & \multicolumn{2}{|c|}{ X-Y position } \\
\hline & & & & & & \multirow{2}{*}{$\begin{array}{l}30 \% \\
\text { po }\end{array}$} & \multirow{2}{*}{$\begin{array}{l}3 \% \\
\mathrm{el}\end{array}$} & \multirow{2}{*}{$\begin{array}{l}67 \% \\
p l\end{array}$} & \multirow{2}{*}{$\begin{array}{l}+27 \\
X\end{array}$} & \multirow{2}{*}{\begin{tabular}{|l|}
-29 \\
$Y$ \\
\end{tabular}} \\
\hline & 1 & 2 & 3 & 4 & 5 & & & & & \\
\hline II Ideational & $\mathrm{pl}$ & po & po & elpl & popl & $50 \%$ & $10 \%$ & $40 \%$ & +40 & +17 \\
\hline IS Social & $\mathrm{pl}$ & popl & $\mathrm{pl}$ & $\mathrm{pl}$ & popl & $20 \%$ & & $80 \%$ & +20 & -52 \\
\hline IP Presentational & $\mathrm{pl}$ & popl & $\mathrm{pl}$ & popl & $\mathrm{pl}$ & $20 \%$ & & $80 \%$ & +20 & -52 \\
\hline
\end{tabular}

Table BI4

\begin{tabular}{|c|c|c|c|c|c|c|c|c|c|c|}
\hline \multicolumn{11}{|c|}{ Corbyn 2017 , speech 19} \\
\hline \multirow{2}{*}{$\begin{array}{l}\text { Dimensions } \\
\text { Total score }\end{array}$} & \multicolumn{5}{|c|}{ Elements } & \multicolumn{3}{|c|}{ Styles (\%) } & \multicolumn{2}{|c|}{ X-Y position } \\
\hline & \multicolumn{5}{|c|}{ Populist/pluralist } & $60 \%$ & & $40 \%$ & +60 & +17 \\
\hline Sub-scores & $\mathrm{I}$ & 2 & 3 & 4 & 5 & po & el & $\mathrm{pl}$ & $x$ & $\mathrm{Y}$ \\
\hline II Ideational & $\mathrm{pl}$ & po & popl & popl & po & $60 \%$ & & $40 \%$ & +60 & +17 \\
\hline IS Social & po & po & popl & popl & po & $80 \%$ & & $20 \%$ & +80 & +52 \\
\hline IP Presentational & $\mathrm{pl}$ & po & $\mathrm{pl}$ & popl & popl & $40 \%$ & & $60 \%$ & +40 & -17 \\
\hline
\end{tabular}

\section{Table BI5}


The Netherlands:

Wilders 20I6-20I7, speech 20 and 21

\begin{tabular}{|c|c|c|c|c|c|c|c|c|c|c|}
\hline \multirow{3}{*}{\begin{tabular}{|l|} 
Dimensions \\
Total score \\
Sub-scores \\
\end{tabular}} & \multirow{2}{*}{\multicolumn{5}{|c|}{$\begin{array}{l}\text { Elements } \\
\text { Populist }\end{array}$}} & \multicolumn{3}{|c|}{ Styles (\%) } & \multicolumn{2}{|c|}{$X-Y$ position } \\
\hline & & & & & & \multirow{2}{*}{$\begin{array}{l}97 \% \\
\text { po }\end{array}$} & \multirow[b]{2}{*}{ el } & \multirow{2}{*}{$\begin{array}{l}3 \% \\
\mathrm{pl}\end{array}$} & \multirow{2}{*}{$\begin{array}{l}+97 \\
\times\end{array}$} & \multirow{2}{*}{$\begin{array}{l}+81 \\
Y Y\end{array}$} \\
\hline & I & 2 & 3 & 4 & 5 & & & & & \\
\hline II Ideational & po & po & po & po & po & $100 \%$ & & & +100 & +87 \\
\hline IS Social & po & po & po & po & po & $100 \%$ & & & +100 & +87 \\
\hline IP Presentational & po & po & po & po & popl & $90 \%$ & & $10 \%$ & +90 & +69 \\
\hline
\end{tabular}

Table BI6

\begin{tabular}{|c|c|c|c|c|c|c|c|c|c|c|}
\hline \multicolumn{11}{|c|}{ Roemer 2017, speech 22 and 23} \\
\hline \multirow{3}{*}{$\begin{array}{l}\text { Dimensions } \\
\text { Total score } \\
\text { Sub-scores }\end{array}$} & \multirow{2}{*}{\multicolumn{5}{|c|}{$\begin{array}{l}\text { Elements } \\
\text { Populist/pluralist }\end{array}$}} & \multicolumn{3}{|c|}{ Styles (\%) } & \multicolumn{2}{|c|}{$\mathrm{X}-\mathrm{Y}$ position } \\
\hline & & & & & & \multirow{2}{*}{$\begin{array}{l}70 \% \\
\text { po }\end{array}$} & \multirow{2}{*}{\begin{tabular}{|l|} 
\\
el
\end{tabular}} & \multirow{2}{*}{$\begin{array}{l}30 \% \\
\mathrm{pl}\end{array}$} & \multirow{2}{*}{$\begin{array}{l}+70 \\
X\end{array}$} & \multirow{2}{*}{\begin{tabular}{|l|}
+35 \\
$Y$
\end{tabular}} \\
\hline & $\mathrm{I}$ & 2 & 3 & 4 & 5 & & & & & \\
\hline II Ideational & $\mathrm{pl}$ & popl & po & plpo & po & $60 \%$ & & $40 \%$ & +60 & +17 \\
\hline IS Social & $\mathrm{pl}$ & po & po & po & po & $80 \%$ & & $20 \%$ & +80 & +52 \\
\hline IP Presentational & popl & po & $\mathrm{pl}$ & po & po & $70 \%$ & & $30 \%$ & +70 & +35 \\
\hline
\end{tabular}

Table BI7 


\begin{tabular}{|c|c|c|c|c|c|c|c|c|c|c|}
\hline \multicolumn{11}{|c|}{ Baudet 2017, speech 24,25 and 26} \\
\hline \multirow{3}{*}{$\begin{array}{l}\text { Dimensions } \\
\text { Total score } \\
\text { Sub-scores }\end{array}$} & \multirow{2}{*}{\multicolumn{5}{|c|}{$\begin{array}{l}\text { Elements } \\
\text { Populist/elitist }\end{array}$}} & \multicolumn{3}{|c|}{ Styles (\%) } & \multicolumn{2}{|c|}{ X-Y position } \\
\hline & & & & & & \multirow{2}{*}{\begin{tabular}{|l|}
$70 \%$ \\
po
\end{tabular}} & \multirow{2}{*}{$\begin{array}{l}30 \% \\
\text { el }\end{array}$} & \multirow[b]{2}{*}{$\mathrm{pl}$} & \multirow{2}{*}{$\begin{array}{l}+40 \\
\times\end{array}$} & \multirow{2}{*}{$\begin{array}{l}+87 \\
Y\end{array}$} \\
\hline & I & 2 & 3 & 4 & 5 & & & & & \\
\hline II Ideational & po & poel & po & poel & po & $80 \%$ & $20 \%$ & & +60 & +87 \\
\hline IS Social & poel & poel & po & poel & po & $70 \%$ & $30 \%$ & & +40 & +87 \\
\hline IP Presentational & poel & poel & poel & poel & po & $60 \%$ & $40 \%$ & & +20 & +87 \\
\hline
\end{tabular}

\section{Table BI8}

\begin{tabular}{|c|c|c|c|c|c|c|c|c|c|c|}
\hline \multicolumn{11}{|c|}{ Baudet 2018 , speech 27} \\
\hline \multirow{2}{*}{$\begin{array}{l}\text { Dimensions } \\
\text { Total score }\end{array}$} & \multirow{2}{*}{\multicolumn{5}{|c|}{$\begin{array}{l}\text { Elements } \\
\text { populist/pluralist }\end{array}$}} & \multicolumn{3}{|c|}{ Styles (\%) } & \multicolumn{2}{|c|}{ X-Y position } \\
\hline & & & & & & \multirow{2}{*}{$\begin{array}{l}73 \% \\
\text { po }\end{array}$} & \multirow{2}{*}{$\begin{array}{l}27 \% \\
\text { el }\end{array}$} & \multirow[b]{2}{*}{$\mathrm{pl}$} & \multirow{2}{*}{$\begin{array}{l}+47 \\
X\end{array}$} & \multirow{2}{*}{\begin{tabular}{|l|}
+87 \\
$Y$ \\
\end{tabular}} \\
\hline Sub-scores & I & 2 & 3 & 4 & 5 & & & & & \\
\hline II Ideational & po & po & po & po & po & $100 \%$ & & & +100 & +87 \\
\hline IS Social & poel & poel & poel & poel & po & $60 \%$ & $40 \%$ & & +20 & +87 \\
\hline IP Presentational & poel & poel & poel & poel & po & $60 \%$ & $40 \%$ & & +20 & +87 \\
\hline
\end{tabular}

Table BI9

\begin{tabular}{|c|c|c|c|c|c|c|c|c|c|c|}
\hline \multicolumn{11}{|c|}{ Baudet 2019, speech 28} \\
\hline \multirow{2}{*}{$\begin{array}{l}\text { Dimensions } \\
\text { Total score }\end{array}$} & \multicolumn{5}{|c|}{ Elements } & \multicolumn{3}{|c|}{ Styles (\%) } & \multicolumn{2}{|c|}{$\mathrm{X}-\mathrm{Y}$ position } \\
\hline & \multicolumn{5}{|c|}{ populist/pluralist } & $70 \%$ & $30 \%$ & & +40 & +87 \\
\hline Sub-scores & I & 2 & 3 & 4 & 5 & po & el & $\mathrm{pl}$ & $\mathrm{X}$ & $\mathrm{Y}$ \\
\hline II Ideational & po & poel & po & poel & po & $80 \%$ & $20 \%$ & & +60 & +87 \\
\hline IS Social & poel & poel & poel & poel & po & $60 \%$ & $40 \%$ & & +20 & +87 \\
\hline IP Presentational & poel & poel & poel & po & po & $70 \%$ & $30 \%$ & & +40 & +87 \\
\hline
\end{tabular}

\footnotetext{
Table B20
} 


\begin{tabular}{|c|c|c|c|c|c|c|c|c|c|c|}
\hline \multicolumn{11}{|c|}{ Rutte 2012 , speech 29 and 30} \\
\hline \multirow{3}{*}{$\begin{array}{l}\text { Dimensions } \\
\text { Total score } \\
\text { Sub-scores }\end{array}$} & \multirow{2}{*}{\multicolumn{5}{|c|}{\begin{tabular}{|l|} 
Elements \\
Elitist/pluralist \\
\end{tabular}}} & \multicolumn{3}{|c|}{ Styles (\%) } & \multicolumn{2}{|c|}{ X-Y position } \\
\hline & & & & & & \multirow{2}{*}{$\begin{array}{l}3 \% \\
\text { po }\end{array}$} & \multirow{2}{*}{$\begin{array}{l}47 \% \\
\text { el }\end{array}$} & \multirow{2}{*}{$\begin{array}{l}50 \% \\
\mathrm{pl}\end{array}$} & \multirow{2}{*}{\begin{tabular}{|l|}
-43 \\
$X$ \\
\end{tabular}} & \multirow{2}{*}{\begin{tabular}{|l|}
0 \\
$Y$
\end{tabular}} \\
\hline & I & 2 & 3 & 4 & 5 & & & & & \\
\hline II Ideational & elpl & el & el & el & $\mathrm{pl}$ & & $70 \%$ & $30 \%$ & -70 & +35 \\
\hline IS Social & $\mathrm{pl}$ & el & elpl & elpl & elpl & & $50 \%$ & $50 \%$ & -50 & 0 \\
\hline IP Presentational & popl & $\mathrm{pl}$ & $\mathrm{pl}$ & el & $\mathrm{pl}$ & $10 \%$ & $20 \%$ & $70 \%$ & -10 & -35 \\
\hline
\end{tabular}

Table B2I

\begin{tabular}{|c|c|c|c|c|c|c|c|c|c|c|}
\hline \multicolumn{11}{|c|}{ Zandt I946, speech 3I } \\
\hline \multirow{3}{*}{$\begin{array}{l}\text { Dimensions } \\
\text { Total score } \\
\text { Sub-scores }\end{array}$} & \multirow{2}{*}{\multicolumn{5}{|c|}{$\begin{array}{l}\text { Elements } \\
\text { Elitist-populist }\end{array}$}} & \multicolumn{3}{|c|}{ Styles (\%) } & \multicolumn{2}{|c|}{ X-Y position } \\
\hline & & & & & & \multirow{2}{*}{$\begin{array}{l}37 \% \\
\text { po }\end{array}$} & \multirow{2}{*}{\begin{tabular}{|l|}
$43 \%$ \\
el \\
\end{tabular}} & \multirow{2}{*}{$\begin{array}{l}20 \% \\
\mathrm{pl}\end{array}$} & \multirow{2}{*}{$\begin{array}{l}-7 \\
X\end{array}$} & \multirow{2}{*}{$\begin{array}{l}+52 \\
Y\end{array}$} \\
\hline & I & 2 & 3 & 4 & 5 & & & & & \\
\hline II Ideational & el & po & $\mathrm{pl}$ & poel & poel & $40 \%$ & $40 \%$ & $20 \%$ & 0 & +52 \\
\hline IS Social & el & poel & poel & poel & poel & $40 \%$ & $60 \%$ & & -30 & +69 \\
\hline IP Presentational & elpl & po & poel & poel & popl & $50 \%$ & $30 \%$ & $20 \%$ & +10 & +35 \\
\hline
\end{tabular}

Table B22 


\section{Appendix C: Inductive versus Structural features of populism}

\begin{tabular}{|c|c|c|c|}
\hline \multicolumn{2}{|c|}{$\begin{array}{l}\text { The } 5 \text { elements and } 3 \text { dimensions of } \\
\text { the core structure of political style }\end{array}$} & \multirow{2}{*}{$\begin{array}{l}\text { Populist features in the } \\
\text { PEP-index (appendix D) } \\
\text { The people as one good } \\
\text { and capable body. }\end{array}$} & \multirow{2}{*}{$\begin{array}{l}\text { Rooduijn's (20I4) inductive } \\
\text { features of populism (bold: } \\
\text { belonging to populism's } \\
\text { core) } \\
3 \text { Homogeneity of the } \\
\text { people } \\
5 \text { Exclusionism }\end{array}$} \\
\hline I The people & Ideational & & \\
\hline & Social & $\begin{array}{l}\text { Populists are part of one } \\
\text { homogeneous/unified } \\
\text { people. }\end{array}$ & $\begin{array}{l}\text { I People-centrism } \\
5 \text { Exclusionism }\end{array}$ \\
\hline & Presentational & $\begin{array}{l}\text { Voice of the people in } \\
\text { language of the people: } \\
\text { identification. }\end{array}$ & $\begin{array}{l}5 \text { Exclusionism } \\
7 \text { Simplistic language } \\
8 \text { Direct Communication } \\
\text { Style } \\
\text { I2 Loosely mediated } \\
\text { relationship }\end{array}$ \\
\hline \multirow[t]{3}{*}{2 The political elite } & Ideational & The elite as bad / not right. & 2 Anti-Elitism \\
\hline & Social & $\begin{array}{l}\text { Populists do not belong to } \\
\text { the elite: no power to the } \\
\text { elite. }\end{array}$ & $\begin{array}{l}2 \text { Anti-Elitism } \\
\text { I0 Image of the outsider } \\
\text { I } 2 \text { Loosely mediated } \\
\text { relationship }\end{array}$ \\
\hline & Presentational & $\begin{array}{l}\text { Emotional, accusatory } \\
\text { language towards the elite: } \\
\text { blaming. }\end{array}$ & $\begin{array}{l}2 \text { Anti-Elitism } \\
\text { 10 Image of the outsider }\end{array}$ \\
\hline \multirow[t]{3}{*}{$\begin{array}{l}3 \text { Democracy I } \\
\text { government }\end{array}$} & Ideational & $\begin{array}{l}\text { Democracy is self- } \\
\text { governance of the people. }\end{array}$ & 4 Direct Democracy \\
\hline & Social & $\begin{array}{l}\text { Exclusive power to the real } \\
\text { people or one of us. }\end{array}$ & $\begin{array}{ll}4 & \text { Direct Democracy } \\
\text { II } & \text { Centralization of leader }\end{array}$ \\
\hline & Presentational & $\begin{array}{l}\text { Messages / solutions based } \\
\text { on the people's "common } \\
\text { sense." }\end{array}$ & $\begin{array}{l}7 \text { Simplistic language } \\
8 \text { Direct Communication } \\
\text { Style }\end{array}$ \\
\hline \multirow[t]{3}{*}{4 Politics } & Ideational & $\begin{array}{l}\text { Politics is a fight and is } \\
\text { about changing the status } \\
\text { quo. }\end{array}$ & 9 Polarization \\
\hline & Social & $\begin{array}{l}\text { Conflict: belief that } \\
\text { compromises are betrayals } \\
\text { of the people. }\end{array}$ & 9 Polarization \\
\hline & Presentational & $\begin{array}{l}\text { Polarization style; stirring } \\
\text { the people. }\end{array}$ & 9 Polarization \\
\hline \multirow[t]{3}{*}{5 Context } & Ideational & $\begin{array}{l}\text { Focus on crisis / what has } \\
\text { been lost. }\end{array}$ & $\begin{array}{l}6 \text { Proclamation of a } \\
\text { crisis }\end{array}$ \\
\hline & Social & $\begin{array}{l}\text { The people / the populist } \\
\text { as "the hero." }\end{array}$ & $\begin{array}{l}2 \text { Anti-Elitism } \\
10 \text { Image of the outsider }\end{array}$ \\
\hline & Presentational & $\begin{array}{l}\text { Negative, pessimistic } \\
\text { language, enlarging crises. }\end{array}$ & $\begin{array}{l}6 \text { Proclamation of a } \\
\text { crisis }\end{array}$ \\
\hline
\end{tabular}

Table Cl 


\section{Appendix D: Six Political Styles Relatively Defined}

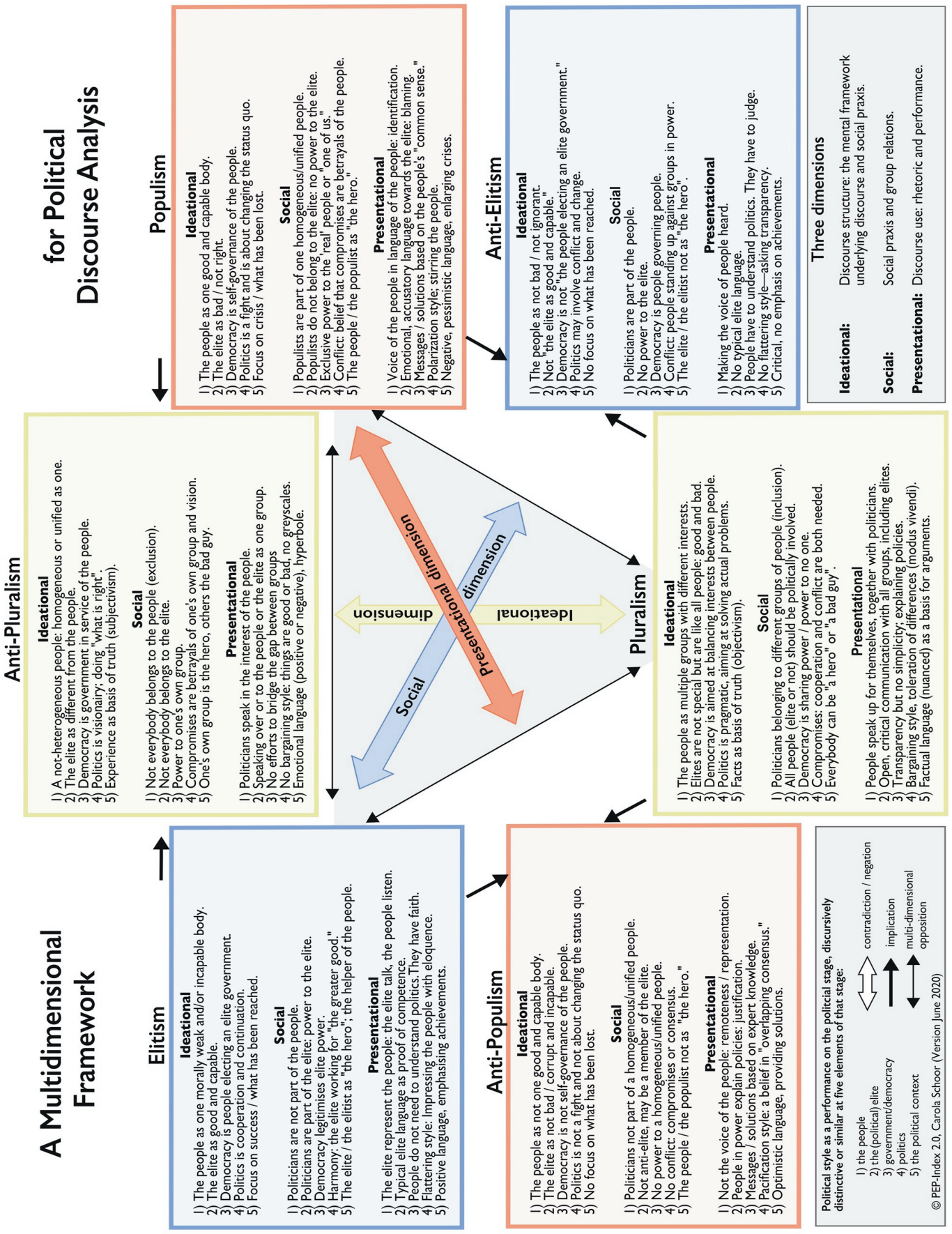

Appendix D Figure D/ Six Political Styles Relatively Defined 


\section{REFERENCES}


Aerts, R. (2003). Emotie in de politiek: Over politieke stijlen in Nederland sinds 1848.

[Emotion in politics: On politcial styles in The Netherlands since 1848.] In C. C. van Baalen, W. Breedveld, J. W. I. Brouwer, P. G. T. W. van Griensven, J. J. M. Ramakers, \& W. P. Secker (Eds.), Jaarboek Parlementaire Geschiedenis (pp. 12-25). Nijmegen, NL: Centrum voor Parlementaire Geschiedenis.

Akkerman, A., Mudde, C., \& Zaslove, A. (2014). How populist are the people? Measuring populist attitudes in voters. Comparative Political Studies, 47(9), I324-I353. doi:

I0.II77/00I04|40I35I2600

Althusser, L. (197I/2008). Ideology and ideological state apparatus. In On ideology (pp. I-60). London, UK: Verso.

Althusser, L. (I97I/20I4). On the reproduction of capitalism: Ideology and ideological state apparatuses. London, UK: Verso.

Ankersmit, F. (1996). Aesthetic politics: Political philosophy beyond fact and value. Stanford, CA: Stanford University Press.

Ankersmit, F. (2000). Politieke stijl: Schumann en Schiller. [Politcial Style: Schumann and Schiller.] In D. Pels \& H. Te Velde (Eds.), Politieke Stijl. Over presentatie en optreden in de politiek. (PP. 15-42). Amsterdam, NL: Spinhuis.

Ankersmit, F. (2003). Democracy's inner voice: Political style as unintended consequence of political action. In J. Corner \& D. Pels (Eds.), Media and the restyling of politics:

Consumerism, celebrity and cynicism. (pP. 19-40). London, UK: Sage Publications. doi: $10.4135 / 978 \mid 446216804 . n 2$

Aristotle. (trans. 1984). The complete works of Aristotle: The revised Oxford translation. (J. Barnes, Ed.). Princeton, NJ: Princeton University Press.

Aslanidis, P. (2016a). Is populism an ideology? A refutation and a new perspective. Political Studies, 64(I S), 88-104. doi: 10.1 I I I/I467-9248.12224

Aslanidis, P. (2016b). Populist social movements of the great recession. Mobilization: An International Quarterly, 2 I(3), 30I-32I. doi: I0. I78I3/I086-67Ix-20-3-30 I

Aslanidis, P. (2017). Avoiding bias in the study of populism. Chinese Political Science Review, 2(3), 266-287. doi: 10.1007/s4 I I II-0I7-0064-0

Aslanidis, P. (2018). Populism as a collective action master frame for transnational mobilization. Sociological Forum, (33), 443-464. doi: 10.1 I I I/socf. 12424 
Augé, A. (2019). How metaphor scenarios can reveal socio-cultural and linguistic variations of meaning: a crosslinguistic perspective on the "NURTURING PARENT" and the "STRICT FATHER" frames. Metaphor and Symbol, 34(4), 209-228. doi:

I0.1080/10926488.2019.1683949

Austin, J. L. (1962). How to do things with words. (J. O. Urmson \& M. Sbisà, Eds.) (2nd ed.). Cambridge, MA: Harvard University Press.

Bachrach, P. (197I). Introduction. In P. Bachrach (Ed.), Political elites in a democracy (PP. I-I2). New York, NY: Atherton Press.

Bachrach, P. (1980). The theory of democratic elitism: A critique. Lanham, MD: University Press of America.

Baumgartner, F. R., Linn, S., \& Boydstun, A. E. (2010). The decline of the death penalty: How media framing changed capital punishment in America. In B. J. Schaffner \& P. J. Sellers (Eds.), Winning with words: The origins and impact of political framing. New York, NY: Routledge, Taylor and Francis.

Best, H., \& Higley, J. (20I0). Introduction: Democratic elitism reappraised. In H. Best \& J. Higley (Eds.), Democratic Elitism: New Theoretical and Comparative Perspectives (pp. I-22). Leiden, NL: Brill. doi: I0.I I63/ej.9789004 I79394.i-230.6

Black, M. ( 1954). Metaphor. The Aristotelian Society, 55, 273-294.

Blokland, H. (20I I). Pluralism, democracy and political knowledge. Surrey, UK: Ashgate.

Bonikowski, B., \& Gidron, N. (2016). The populist style in American politics: Presidential campaign discourse, 1952-1996. Social Forces, 94(4), I593-I62I. https://doi.org/10.1093/sf/sov120

Borchert, J. (2010). "They ain't making elites like they used to": The never ending trouble with democratic elitism. In H. Best \& J. Higley (Eds.), Democratic elitism : New theoretical and comparative perspectives (pp. 23-4I). Leiden, NL: Brill. doi:

I0.1 I 63/ej.9789004 I79394.i-230.12

Bourdieu, P. (1985). The social space and the genesis of groups. Theory and Society, I4(6), 723-744. doi: 10.1007/BF00174048

Bowdle, B. F., \& Gentner, D. (2005). The career of metaphor. Psychological Review, I/2(I), 193-2 16. doi.org: 10.1037/0033-295X.I 12.1.193

Butler, J. (1988). Performative acts and gender constitution: An essay in phenomenology and feminist theory. Theatre Journal, 40(4), 519. doi: 10.2307/3207893

Butler, J. (1993). Critically queer. GLQ, I(I), I7-32. doi: I0.12I5/I0642684-I-I-I7 
Canovan, M. (1999). Trust the people! Populism and the two faces of democracy. Political Studies, 47(I), 2-16. doi: 10.1 III/I467-9248.00184

Canovan, M. (2002). Taking politics to the people: Populism as the ideology of democracy. In

Y. Mény \& Y. Surel (Eds.), Democracies and the Populist Challenge (pp. 25-44).

Basingstoke, UK: Palgrave Macmillan.

Carey, C. (1996). Rhetorical means of persuasion. In A. Oksenberg Rorty (Ed.), Essays on

Aristotle's Rhetoric. Berkely, CA: University of California Press.

Chandler, D. (2002). Semiotics: The basics. London, UK: Routledge.

Charteris-Black, J. (2005). Politicians and rhetoric: The persuasive power of metaphor.

Basingstoke, UK: Palgrave Macmillan.

Charteris-Black, J. (2009). Metaphor and political communication. In A. Musolff \& J. Zinken

(Eds.), Metaphor and discourse (pp. 97-I I5). Basingstoke, UK: Palgrave Macmillan. doi: 10.1057/9780230594647_7

Charteris-Black, J. (20I I). Politicians and rhetoric: The persuasive power of metaphor (2nd ed.). Basingstoke, UK: Palgrave Macmillan.

Charteris-Black, J. (20I2). Forensic deliberations on "purposeful metaphor." Metaphor and the Social World, 2(I), I-2I. doi: I0.1075/msw.2.I.0Icha

Charteris-Black, J. (2014). Analysing political speeches: Rhetoric, discourse and metaphor.

Basingstoke, UK: Palgrave Macmillan. doi: 10.1080/10926488.2016.1223462

Choat, S. (2017). 'Horseshoe theory' is nonsense - the far right and far left have little in common. Retrieved September 21, 2019, from https://theconversation.com/horseshoetheory-is-nonsense-the-far-right-and-far-left-have-little-in-common-77588

Chouliaraki, L., \& Kissas, A. (2018). The communication of horrorism: A typology of ISIS online death videos. Critical Studies in Media Communication. doi:

I0.1080/15295036.2017.1393096

Cicero, M. T. (trans. 20I2). Brutus, or the history of eloquence. In Cicero's Brutus and the Orator (pp. 5-78). Unknown: CreateSpace Independent Publishing Platform.

Corner, J. (2003). Mediated persona and political culture. In J. Corner \& D. Pels (Eds.), Media and the restyling of politics: Consumerism, celebrity and cynicism (pp. 67-84). London, UK: Sage Publications Ltd.

Corner, J., \& Pels, D. (2003). Introduction: The restyling of politics. In Media and the restyling of politics. Consumerism, celebrity and cynicism. (pp. I-I8). London, UK: Sage Publications. 
Coupland, N. (2007). Style: Language variation and identity. New York, NY: Cambridge University Press.

Crosby, R. K. (2019). Pauline Hanson, personality, and electoral fortunes. In Grant, B, T. Moore, \& T. Lynch (Eds.), The rise of right-populism. (pp. 103-142). Singapore: Springer. doi.org/I0.1007/978-98|-13-2670-7_6

Culler, J. (1976). Saussure. London, UK: Fontana/Collins.

Dahl, R. A. (I97I). Further reflections on "The elitist theory of democrcay." In P. Bachrach (Ed.), Political Elites in a Democracy (pp. 93-I I5). New York, NY: Atherton Press.

Dahl, R. A. (196I/2005). Who governs? Democracy and power in an American city (2nd ed.). New Haven, CT: Yale University Press.

Dahl, R. A. (1956/2006). A Preface to democratic theory. Expanded edition. Chicago, IL: Chicago University Press.

Dahl, R. A., \& Stinebrickner, B. (2002). Modern political analysis. eBook: Pearson.

Dancygier, B. (2017). Figurativeness, conceptual metaphor, and blending. In E. Semino \& Z. Demjén (Eds.), Routledge handbook of metaphor and language (pP. 29-4I). London, UK: Routledge, Taylor and Francis. doi: 10.4324/978I3 I5672953.ch2

De Cleen, B. (2017). Populism and nationalism. In C. R. Kaltwasser, P. Taggart, P. O. Espejo, \& P. Ostiguy (Eds.), The Oxford handbook of populism (pp. 342-362). New York, NY. doi: 10.1093/oxfordhb/9780198803560.013.18

De Haan, I. (2000). Stijl, vorm, ontwerp: Nadeel en nut van het stijlbegrip voor de politiek. [Style, form, design: Disadvantage and advantage of the style concept for politics]. In D. Pels \& H. te Velde (Eds.), Politieke Stijl: Over presentatie en optreden in de politiek. Amsterdam, NL: Spinhuis.

De Liagre Böhl, H. (20I3). Consensus en polarisatie: De kwaliteit van de democratie 19452000 [Consensus and polarization: The quality of the democracy]. In R. Aerts, H. De Liagre Böhl, P. De Rooy, \& H. Te Velde (Eds.), Land van kleine gebaren: Een politieke geschiedenis van Nederland I 780-20I2 (pp. 285-349). Amsterdam, NL: Boom.

De Saussure, F. (20I5). Course in General Linguistics. London, UK: Forgotten Books.

Den Hollander, J. (2000). Over koude en warme politiek. Distantie bij Plessner en Luhmann. [On cold and warm politcs: Distantion in Plessner's and Luhmann's work]. In D. Pels \& H. te Velde (Eds.), Politieke Stijl. Over presentatie en optreden in de politiek. (Pp. I07-I27). Amsterdam, NL: Spinhuis. 
Dirven, R. (2002). Introduction. In R. Dirven \& R. Pörings (Eds.), Metaphor and metonymy in comparison and contrast (pp. I-38). Berlin, DE: Mouton De Gruyter.

Eco, U. (1983). The scandal of metaphor: Metaphorology and semiotics. Poetics Today, 4(2), 217-257.

Edelman, M. (1988). Constructing the Political Spectacle. Chicago, IL: University of Chicago Press.

Ekström, M., Patrona, M., \& Thornborrow, J. (20I8). Right-wing populism and the dynamics of style: A discourse-analytic perspective on mediated political performances. Palgrave Communications, 4(83). doi: 10.1057/s4I599-0I8-0132-6

Ellemers, N., \& Haslam, S. A. (20I2). Social identity theory. In P. A. M. Van Lange, A. W. Kruglanski, \& E. Tory Higgins (Eds.), Handbook of theories of social psychology (pp. 379398). London, UK: Sage Publishing.

Engelstad, F. (20I0). Democratic elitism: Conflict and consensus. In H. Best \& J. Higley (Eds.), Democratic Elitism: New Theoretical and Comparative Perspectives (pp. 60-76). Leiden, NL: Brill.

Fauconnier, G., \& Turner, M. (2008). Rethinking metaphor. In R. W. Gibbs Jr. (Ed.), The Cambridge handbook of metaphor and thought (Vol. 3I, pp. 53-66). New York, NY: Cambridge University Press. Doi: 10.1017/CBO97805II816802.005

Felluga, D. F. (2015). Critical theory: The key concepts (Routledge Key Guides). New York, NY: Routledge. doi: 10.4324/978I3।57/8873

Fitzgerald, S. (2015). Is there a role for spectators in democratic politics? A reflection on the theatre metaphor in Green's “Ocular democracy.” Constellations, 22(2), 302-3 I3.

Flaming0999. (2019). Just a Reminder. Retrieved September 9, 2019, from https://twitter.com/Flamingo999/status/ I I 71001659453005826 ?s=20

Fligstein, N., \& McAdam, D. (2012). A Theory of fields. New York, NY: Oxford University Press.

Flusberg, S. J., Matlock, T., \& Thibodeau, P. H. (2018). War metaphors in public discourse. Metaphor and Symbol, 33(I). doi: I0.1080/10926488.2018.1407992

Font, N., Graziano, P., \& Tsakatika, M. (2019). Varieties of inclusionary populism? SYRIZA, Podemos and the Five star movement. Government and Opposition, 2 I (I). doi: 10.1017/gov.2019.17 
Fontana, B., Nederman, C. J., \& Remer, G. (2004). Introduction: Deliberative democracy and the rhetorical turn. In B. Fontana, C. J. Nederman, \& G. Remer (Eds.), Talking democracy: Historical perspectives on rhetoric and democracy (Pp. I-25). University Park, PA: The Pennsylvania State University Press.

Fortuyn, P. (2002). De verweesde samenleving. [The orphanized society.] Uithoorn, NL: Karakter Uitgevers.

Frede, D. (1992). The Cognitive role of phantasia in Aristotle. In M. C. Nussbaum \& A. Oksenberg Rorty (Eds.), Essays on Aristotle's De anima (pp 279-296). Oxford, UK: Clarendon Press.

Freeden, M. (1996). Ideologies and political theory: A conceptual approach. Oxford, UK: Oxford University Press.

Freeden, M. (2003). Ideology: A very short introduction. New York, NY: Oxford University Press.

Freeden, M. (2017). After the Brexit referendum: Revisiting populism as an ideology. Journal of Political Ideologies, 22(I), I-I I. Doi: 10.1080/I35693 I7.2016.12608I3

Friedman, T. L. (20I4). Putin and the laws of gravity. The New York Times. Retrieved from https://www.nytimes.com/2014/03/26/opinion/friedman-putin-and-the-laws-ofgravity.html

Garsten, B. (2006). Saving persuasion: A defense of Rhetoric and Judgment. Cambridge, MA: Harvard University Press.

Gentner, Dedre, Bowdle, B. F., Wolff, P., \& Boronat, C. (200I). Metaphor is like analogy. In D. Gentner, K. J. Holoyoak, \& B. N. Kokinov (Eds.), The analogical mind: Perspectives from cognitive science (Pp. 199-253). Cambridge, MA: MIT Press.

Gerbaudo, P. (2017). The mask and the flag: Populism, citizenism and global protest. New York, NY: Oxford University Press. doi: 10.1017/S0047279417000897

Gibbs, Jr., R. W. (20II). Are 'deliberate' metaphors really deliberate? A question of human consciousness and action. Metaphor and the Social World, I(I), 26-5I. doi: 10.1075/msw.I.I.03gib

Giddens, A. (199I). Modernity and self-identity: Self and society in the late modern age. Stanford, CA: Stanford University Press.

Gidron, N., \& Bonikowski, B. (20I3). Varieties of populism: Literature review and research agenda. Working papers series, (13-0004). 
Glynos, J., \& Howarth, D. (2007). Logics of critical explanation in social and political theory. Oxon, UK: Routledge, Taylor and Francis. doi: 10.4324/9780203934753

Goffman, E. (1956). The presentation of self in everyday life. Edinburgh, UK: University of Edinburgh Social Sciences Research Centre.

Gouldner, A. (1976). The dialectic of ideology and technology. New York, NY: The Seabury Press.

Green, J. E. (20I0). The eyes of the people: Democracy in an age of spectatorship. New York, NY: Oxford University Press. doi: 10.1080/10584609.20 I I.58887 I

Greimas, A. J. (1970/I987). On meaning: Selected writings in semiotic theory. Minneapolis, MN: University of Minnesota Press.

Greimas, A. J. (1991). De betekenis als verhaal: Semiotische opstellen. [Meaning as narrative: Semiotic essays]. Amsterdam, NL: John Benjamins.

Greimas, A. J., \& Parret, H. (197I/20I7). A.J. Greimas. In H. Parret (Ed.), Discussing language : Dialogues with Wallace L. Chafe, Noam Chomsky, Algirdas J. Greimas, M. A. K. Halliday, Peter Hartmann, George Lakoff, Sydney M. Lamb, André Martinet, James McCawley, Sebastian K. Saumjan, Jacques Bouveresse. (pp. 55-79). Berlin, DE: Mouton De Gruyter.

Halliday, M. A. K., \& Mathiessen, C. (2004). An introduction to functional grammar (3rd ed.). London, UK: Arnold.

Hariman, R. (1995). Political style: The artistry of power. Chicago, IL: University of Chicago Press.

Hawkins, K. (2009). Is Chávez populist? Measuring populist discourse in comparative perspective. Comparative Political Studies, 42(8), 1040- I067. doi:

|0.1|77/00104|400933|72|

Hawkins, K., \& Kaltwasser, C. R. (2017). What the (ideational) study of populism can teach us, and what it can't. Swiss Political Science Review, 23(4), 526-542. doi:

10.1 III/spsr.12281

Hawkins, K., Riding, S., \& Mudde, C. (20I2). Measuring populist attitudes (The C \& M Working Papers series). Mexico-City: IPSA.

Hébert, L. (2019). Tools for text and image analysis. An introduction to applied semiotics. London, UK: Routledge, Taylor and Francis.

Herrnstein Smith, B. (2016). What was “close reading"? The Minnesota Review, 20I6(87), 5775. doi: $10.1215 / 00265667-3630844$ 
Hook, J. (2019, March 18). The burden of a 40-year career: Some of Joe Biden's record doesn't age well. The L.A. Times.

Jagers, J., \& Walgrave, S. (2007). Populism as a political communication style: An empirical study of political parties' discourse in Belgium. European Journal of Political Research, 46(3), 3 I9-345. doi: 10.1 I I I/j. |475-6765.2006.00690.x

Kaltwasser, C. R., Taggart, P., Ochoa Espejo, P., \& Ostiguy, P. (2017). Populism: An overview of the concept and the state of the art. In C. R. Kaltwasser, P. Taggart, P. Ochoa Espejo, \& P. Ostiguy (Eds.), The Oxford handbook of populism (pp. I-26). New York, NY: Oxford University Press. doi: 10.1093/oxfordhb/9780198803560.013.34

Katsambekis, G. (2016). Radical left populism in contemporary Greece: Syriza's trajectory from minoritarian opposition to power. Constellations, 23(3), 391-403. doi:

I0.I I I I/I467-8675. I2234

Katsambekis, G., \& Kioupkiolis, A. (2019). Introduction: The populist radical left in Europe. In The populist radical left in Europe (pp. 21-46). Oxon: Routledge.

Kazin, M. (1995). The populist persuasion: An American history. (Revised ed). New York, NY.

Kazin, M. (2016, March 22). How can Donald Trump and Bernie Sanders both be 'Populist'?

The New York Times. Retrieved from

https://www.nytimes.com/20I6/03/27/magazine/how-can-donald-trump-and-berniesanders-both-be-populist.html

Kennedy, G. A. (1999). Classical rhetoric and its Christian and secular tradition from ancient to modern times (2nd ed.). Chapel Hill, NC: The University of North Carolina Press.

Kirby, J. T. (1997). Aristotle on metaphor. The American Journal of Philology, I I 8(4), 5I 7-554.

Koenis, S. (2014). Voices of the people: Pluralism in Dutch politics (1994-2014). Amsterdam, NL: VU University Press.

Kopan, T. A. I. (20I4). Tom Perkins apologizes for "Kristalnacht." Retrieved from http://www.politico.com/story/2014/0I/tom-perkins-letter-to-the-editor-kristallnachtI027|3.html

Körösényi, A. (2010). Beyond the happy consensus about democratic elitism. In H. Best \& J. Higley (Eds.), Democratic Elitism : New Theoretical and Comparative Perspectives (pp. 4259). Leiden, NL: Brill.

Kövecses, Z. (2002). Metaphor: A practical introduction (2nd ed.). New York, NY: Oxford University Press. 
Kövecses, Z. (2017). Conceptual metaphor theory. In E. Semino \& Z. Demjén (Eds.), The Routledge handbook of metaphor and language (Pp. 13-28). Oxon, UK: Routledge, Taylor and Francis.

Laclau, E. (2005a). On populist reason. London, UK: Verso.

Laclau, E. (2005b). Populism: what's in a name? In F. Panizza (Ed.), Populism and the mirror of democracy (pp. 32-49). London, UK: Verso.

Laclau, E. (2006). Why constructing a people is the main task of radical politics. Critical Inquiry, 32(4), 646-680. doi: 10.1086/508086

Laclau, E. (20I4). The rhetorical foundations of society. London, UK: Verso.

Laclau, E., \& Mouffe, C. (1985). Hegemony and socialist strategy. London, UK: Verso. https://doi.org// 0.1017/CBO978I I074I5324.004

Laclau, E., \& Mouffe, C. (200I). Preface to the second edition. In Hegemony and socialist strategy (2nd ed., pp. vi-xix). London, UK: Verso.

Laclau, E., \& Zac, L. (1994). Minding the gap: The subject of politics. In The Making of Political Identities (Pp. I I-39). London, UK: Verso.

Lakoff, G. (1993). The contemporary theory of metaphor. In A. Ortony (Ed.), Metaphor and thought (PP. 202-25I). Cambridge, UK: Cambridge University Press.

Lakoff, G. (1995). Metaphor, morality and politics: Or why conservatives have left liberals in the dust. Social Research, 62(2), I-22.

Lakoff, G. (2004). Don't think of an elephant!: Know your values and frame the debate. White River Junction, VT: Chelsea Green Publishing.

Lakoff, G. (2008). The neural theory of metaphor. In R. W. Gibbs (Ed.), The Cambridge handbook of metaphor and thought (Pp. 17-38). Cambridge, UK: Cambridge University Press.

Lakoff, G. (20I4). Metaphor and war: The metaphor system used to justify war in the Gulf. Cognitive Semiotics, 4(2), 5-19. doi: 10.1515/cogsem.2009.4.2.5

Lakoff, G., \& Johnson, M. (1980). Metaphors we live by. Chicago, IL: The University of Chicago Press.

Lakoff, G., \& Johnson, M. (2003). Afterword 2003. In G. Lakoff \& M. Johnson (Eds.), Metaphors we live by (2nd ed., Pp. 243-276). Chicago, IL: The University of Chicago Press.

Lasswell, H. D., Lerner, D., \& Rothwell, C. E. (197I). The elite concept. In P. Bachrach (Ed.), Political elites in a democracy (pp. 13-26). New York, NY: Atherton Press. 
Lijphart, A. (1968). The politics of accommodation: Pluralism and democracy in The Netherlands. Berkeley, CA: University of California Press.

Lucardie, P. (2008). The Netherlands: Populism versus pillarization. In Twenty-first century populism: The spectre of Western European democracy (PP. I5I-165). Basingstoke, UK: Palgrave Macmillan.

Mackie, G. (2009). Schumpeter's leadership democracy. Political Theory, 37(I), I28-I53. doi: I0.1I77/009059|708326642

Mahon, J. E. (1999). Getting your sources right: What Aristotle didn't say. In L. Cameron \& G. Low (Eds.), Researching and applying metaphor (pp. 69-80). Cambridge, UK: Cambridge University Press. doi: 10.1017/CBO978I I39524704.007

Maiguashca, B., \& Dean, J. (2019). Corbynism, populism and the re-shaping of left politics in contemporary Britain. In G. Katsambekis \& A. Kioupkiolis (Eds.), The populist radical left in Europe (pp. 145-167). London, UK: Routledge, Taylor and Francis. doi: 10.4324/978|3|5|80823-8.

Manin, B. (1997). The principles of representative government. Cambridge, UK: Cambridge University Press.

Martin, J. (20I3). Politics and rhetoric: A critical introduction. London, UK: Routledge.

Maslen, R. (20I7). Finding systematic metaphors. In E. Semino \& Z. Demjén (Eds.), The Routledge handbook of metaphor and language (pp. 89-I0I). Oxon, UK: Routledge, Taylor and Francis. doi: 10.4324/9781315672953

Miró, J. (2019). Beyond populism and institutionalism: Anti-populism and the management of austerity in Spain. Constellations. doi: I0. I I I I/ I467-8675.12386

Moffitt, B. (20I5). How to perform crisis: A model for understanding the key role of crisis in contemporary populism. Government and Opposition, 50(02), 189-217. doi: 10.1017/gov.2014.13

Moffitt, B. (2016). The global rise of populism: Performance, political style, and representation. Stanford, CA: Stanford University Press.

Moffitt, B. (20I7). Liberal illiberalism? The reshaping of the contemporary populist radical right in Northern Europe. Politics and Governance, 5(4), I I2-I 22.

Moffitt, B., \& Tormey, S. (20I4). Rethinking populism: Politics, mediatisation and political style. Political Studies, 62, 381-397.

Mouffe, C. (2018a). For a left populism. London, UK: Verso. 
Mouffe, C. (2018b). Jeremy Corbyn's left populism. Retrieved from https://www.versobooks.com/blogs/3743-jeremy-corbyn-s-left-populism

Mudde, C. (2004). The populist Zeitgeist. Government and Opposition, 39(4), 542-563.

Mudde, C. (2017). Populism: An ideational approach. In C. R. Kaltwasser, P. Taggart, P. Ochoa Espejo, \& P. Ostiguy (Eds.), The Oxford Handbook of Populism (pp. 27-47). New York, NY: Oxford University Press. doi: 10.1093/oxfordhb/9780 I98803560.0 I3.I

Mudde, C., \& Kaltwasser, C. R. (20I2). Exclusionary vs. Inclusionary populism: Comparing contemporary Europe and Latin America. Government and Opposition, 48(2), I47-I74. doi: 10.1017/gov.2012.11

Mudde, C., \& Kaltwasser, C. R. (20I3). Populism. In M. Freeden, L. Tower Sargent, \& M. Stears (Eds.), Oxford handbook of political ideologies (pp. 493-5I2). New York, NY: Oxford University Press.

Mudde, C., \& Kaltwasser, C. R. (2017). Populism: A very short introduction. Very short introductions. New York, NY: Oxford University Press. https://doi.org/10.1093/actrade/9780190234874.00I.000I

Mudde, C., \& Kaltwasser, C. R. (2018). Studying populism in comparative perspective: Reflections on the contemporary and future research genda. Comparative Political Studies. doi: $10.1|77 / 00104| 4018789490$

Müller, J.-W. (2016). What is populism? Philadelphia, PA: University of Pennsylvania Press.

Müller, J. W. (2015). Parsing populism: Who is and who is not a populist these days? Juncture, 22(2), 80-89. doi: 10.1 I I I/j.2050-5876.20I5.00842.x

Musolff, A. (2016). Political metaphor analysis: Discourse and scenarios. London, UK: Bloomsbury Academic. doi: I0.1 I I I/jcom. 12343

Musolff, A. (2017). Metaphor and persuasion in politics. In E. Semino \& Z. Demjén (Eds.), The Routledge handbook of metaphor and language (pp. 309-322). Oxon, UK: Routledge, Taylor and Francis. doi: 10.4324/9781315672953

Night of broken metaphors. (20I4, February 5). The Economist. Retrieved from http://www.economist.com/blogs/democracyinamerica/2014/02/inequality-andenvy?fsrc=scn/tw_ec/night_of_broken_metaphors

Norris, P., \& Inglehart, R. (2019). Cultural backlash. Trump, Brexit, and authoritarian populism. Cambridge, UK: Cambridge University Press. 
Nussbaum, M. C. (1996). Aristotle on emotions and rational persuasion. In A. Oksenberg Rorty (Ed.), Essays on Aristotle’s Rhetoric (Pp. 303-323). Berkeley, CA: University of California Press.

Nussbaum, M. C., \& Putnam, H. (1992). Changing Aristotle’s mind. In M. C. Nussbaum \& A. Oksenberg Rorty (Eds.), Essays on Aristotle's De anima. Oxford, UK: Clarendon Press. Oksenberg Rorty, A. (1996). Structuring rhetoric. In A. Oksenberg Rorty (Ed.), Essays on Aristotle's rhetoric (Pp. I-33). Berkely, CA: University of California Press.

Ortony, A. (1993). Metaphor, language and thought. In A. Ortony (Ed.), Metaphor and thought (2nd ed., Pp. I-16). Cambridge, UK: Cambridge University Press.

Ostiguy, P. (2017). Populism: A socio-cultural approach. In C. R. Kaltwasser, P. Taggart, P. Ochoa Espejo, \& P. Ostiguy (Eds.), The Oxford handbook of populism (pp. 73-100). New York, NY: Oxford University Press.

Palonen, E. (2018). Performing the nation: The Janus-faced populist foundations of illiberalism in Hungary. Journal of Contemporary European Studies, 26(3), 308-32 I. doi: I0.1080/14782804.2018.1498776

Pappas, T. S. (2016). Modern populism: Research advances, conceptual and methodological pitfalls, and the minimal definition. In Politics: Oxford Research Encyclopedias (Pp. I-24). Oxford University Press.

Parret, H. (1989). Introduction. In Paris school of semiotics: Volume I - Theory. Amsterdam, NL: John Benjamins.

Pels, D. (2003a). Aesthetic representation and political style. In J. Corner \& D. Pels (Eds.), Media and the Restyling of Politics. Consumerism, Celebrity and Cynicism. (pp. 4I-66). London, UK: Sage Publications.

Pels, D. (2003b). De geest van Pim: Het gedachtegoed van een politieke dandy [The spirit of Pim: The ideas of a political dandy]. Amsterdam, NL: Anthos.

Pels, D., \& Te Velde, H. (2000). Politieke stijl in perspectief. [Political style in perspective.] In D. Pels \& H. Te Velde (Eds.), Politieke Stijl. Over presentatie en optreden in de politiek. (pp. I-15). Amsterdam, NL: Het Spinhuis.

Perkins, T. (2014, January 24). Progressive Kristalnacht coming? The Wall Street Journal. Retrieved from https://www.wsj.com/articles/progressive-kristallnacht-coming1390600169 
Postma, T. (20I I). Metaphor and register variation: The personalization of Dutch news discourse (Doctoral dissertation Vrije Universiteit, Amsterdam). Retrieved from: https://research.vu.nl/en/publications/metaphor-and-register-variation-thepersonalization-of-dutch-news

Pragglejaz-group. (2007). MIP: A Method for identifying metaphorically used words in discourse. Metaphor and Symbol, 22(I), I-39.

Prentoulis, M., \& Thomassen, L. (2017). Left populism: The challenges from grassroots to electoral politics. Retrieved from https://ueaeprints.uea.ac.uk/63899/

Quintilian. (trans. 2002). The Orator's Education. (D. A. Russell, Ed.) (Loeb Class). Cambridge, MA: Harvard University Press.

Reisigl, M., \& Wodak, R. (20I5). The discourse-historical approach. In R. Wodak \& Michael Meyer (Eds.), Methods of Critical Discourse Studies (3rd ed., PP. 87-I2I). London, UK: Sage Publications.

Richards, I. A. (1936). The philosophy of rhetoric. New York, NY: Oxford University Press.

Ricoeur, P. (1978). The metaphorical process as cognition, imagination and feeling. Critical Inquiry, 5(I), 143-I59.

Ricoeur, P. (1975/2003). The rule of metaphor: The creation of meaning in language. London, UK: Routledge.

Rooduijn, M. (2013). 'A populist zeitgeist? The impact of populism on parties, media and the public in Western Europe' (Doctoral Dissertation, University of Amsterdam UvA). Retrieved from: https://hdl.handle.net/I I245/I.3916I2

Rooduijn, M. (20I4). The nucleus of populism: In search of the lowest common denominator. Government and Opposition, 49(4), 572-598.

Rooduijn, M. (2019, March 2I). The ideologie van Forum voor Democratie. [The ideology of Forum for Democracy.] [Web log message]. Retrieved from http://stukroodvlees.nl/deideologie-van-forum-voor-democratie/

Sartori, G. (1970). Misinformation in comparative politics. The American Political Science Review, 64(4), 1033-1053.

Sartori, G. (1991). Comparing and miscomparing. Journal of Theoretical Politics, 3(3), 243-257. https://doi.org/10.1 I77/095169289100300300 I

Schleifer, R. (1987). A.J. Greimas and the nature of meaning: Linguistics, semiotics and discourse theory. London, UK: Routledge, Taylor, and Francis. 
Schoor, C. (20II). Van oprotpremie tot kopvoddentaks. Metafoorgebruik in veertig jaar immigratiedebat.[From bugoff-bonus to headrag tax: Metaphor in forty years of debating immigration.] Filosofie \& Praktijk, 32(2), 33-47.

Schoor, C. (2019). The political style of speeches before, during and after the Brexit referendum. Conference presentation at The 69th PSA annual international conference, Nottingham, UK, April 15-17, 2019.

Schumpeter, J. A. (2008). Capitalism, socialism and democracy (3rd ed.). New York, NY: HarperCollins Publishers.

Skinner, Q. (1969). Meaning and understanding in the history of ideas. History and Theory, $8(1), 3-53$.

Skinner, Q. (1999). Rhetoric and conceptual change: Contributions to the history of concepts. Finnish Yearbook of Political Thought, 3, 60-73.

Stavrakakis, Y. (2017). Discourse theory in populism research: Three challenges and a dilemma. Journal of Language and Politics, I6(4), 523-534.

Stavrakakis, Y., \& De Cleen, B. (2017). Distinctions and articulations: A discourse theoretical framework for the study of populism and nationalism. Javnost: The Public, 24(4), 30I-319.

Stavrakakis, Y., \& Jäger, A. (20I8). Accomplishments and limitations of the 'new' mainstream in contemporary populism studies. European Journal of Social Theory, 2 I (4), 547-565. https://doi.org//0.1 I77/I368431017723337

Stavrakakis, Y., \& Katsambekis, G. (20/4). Left-wing populism in the European periphery: The case of SYRIZA. Journal of Political Ideologies, 19(2), II9-I42.

Stavrakakis, Y., \& Katsambekis, G. (2019). The populism/anti-populism frontier and its mediation in crisis-ridden Greece: From discursive divide to emerging cleavage? European Politial Science, I8(I), 37-52. doi: 10.1057/s4I304-0 I7-0I38-3

Stavrakakis, Y., Kioupkiolis, A., Katsambekis, G., Nikisianis, N., \& Siomos, T. (2016). Contemporary Left-wing populism in Latin America: Leadership, horizontalism, and postdemocracy in Chávez's Venezuela. Latin American politics and society, 58(3), 5I-76. doi: I0.I I I I/j.I548-2456.20I6.003 I8.x

Steen, G. (2008). The paradox of metaphor: Why we need a three-dimensional model of metaphor. Metaphor and Symbol, 23(4), 2I3-24I. Doi: I0.1080/I0926480802426753

Street, J. (2003). The celebrity politician. In J. Corner \& D. Pels (Eds.), Media and the restyling of politics. Consumerism, celebrity and cynicism. (pp. 85-98). London, UK: Sage Publications. 
Tackett, M. (2019, April 24). Strong support here helped Trump win Pennsylvania in 2016. 2020 could be different. The New York Times. Retrieved from: https://www.nytimes.com/2019/04/24/us/politics/trump-pennsylvania.html Taggart, P. (2002). Populism and the pathalogy of representative politics. In Y. Mény \& Y. Surel (Eds.), Democracies and the Populist Challenge (pp. 62-80). Basingstoke, UK: Palgrave Macmillan.

Taggart, P. (2004). Populism and representative politics in contemporary Europe. Journal of Political Ideologies, 9(3), 269-288.

Taguieff, P.-A. (1998). Populismes et antipopulismes: Le choc des argumentations. [Populism and antipopulism: The shock of arguments. Mots, (55), 5-26.

Taylor, J. (2006). Where did the party go? Columbia, MO: University of Missouri Press.

Te Velde, H. (20I0). Van Regentenmentaliteit tot populisme. [From governors mentality to populism.] Amsterdam, NL: Bert Bakker.

The end of the oil age. (2003, October 23). The Economist. Retrieved from http://www.economist.com/node/21557/7

Thompson, J. B. (1990). Ideology and modern culture: Critical social theory in the era of mass communication (Kindle edi). Cambridge, UK: Polity Press.

Turner, J. C., \& Reynolds, K. J. (20I2). Self-categorization theory. In P. A. M. Van Lange, A. W. Kruglanski, \& E. Tory Higgins (Eds.), Handbook of theories of social psychology (pp. 399-4 I7). London, UK: Sage. doi: 10.4I35/978|446249222.n46

Van Dijk, T. A. (1998). Ideology. A multidisciplinary approach. London, UK: Sage Publications.

Van Dijk, T. A. (20I3). Ideology and Discourse. In M. Freeden \& M. Stears (Eds.), Oxford handbook of political ideologies (pp. 175-196). New York, NY: Oxford University Press. doi: 10.1093/oxfordhb/9780199585977.013.007

Van Dijk, T. A. (20I5). Ideology. In G. Mazzoleni, K. Barnhurst, K. Ikeda, R. Maia, \& H. Wessler (Eds.), The international encyclopedia of political communication (pp. 495-505). London, UK: Wiley-Blackwell.

Van Kessel, S. (20I4). The populist cat-dog: Applying the concept of populism to contemporary European party systems. Journal of Political Ideologies, 19(I), 99-I I8. Doi: 10.1080/13569317.2013.869457

Van Krieken, R. (2018). Celebrity Society: The struggle for attention (2nd ed.). London, UK: Routledge, Taylor and Francis. 
Van Leeuwen, M. (2019). Measuring people-centrism in populist political discourse: A linguistic approach. In J. Zienkovski \& R. Breeze (Eds.), Imagining the people of Europe: Populist discourses across the political spectrum (Pp. 315-339). Amsterdam, NL: Benjamins. doi: 10.1075/dapsac.83.13lee

Weiss, G., \& Wodak, R. (2003). Introduction: Theory, interdisciplinarity and critical discourse analysis. In Critical discourse analysis: Theory and interdisciplinarity. Basingstoke, UK: Palgrave Macmillan.

Weyland, K. (200I). Clarifying a contested concept. Comparative Politics, 34(I), I-22. Doi: $10.2307 / 422412$

Weyland, K. (2017). Populism: A political-strategic approach. In C. R. Kaltwasser, P. Taggart, P. Ochoa Espejo, \& P. Ostiguy (Eds.), The Oxford handbook of populism (pp. 48-72). New York, NY: Oxford University Press. doi: 10.1093/oxfordhb/9780198803560.013.2

Wilders, G. (20I2). Join our protest against the profiteering eurocrats. Retrieved from http://www.stopeuprofiteers.com

Wodak, R. (200I). What CDA is about: a summary of its history, important concepts and its developments. In R. Wodak \& M. Meyer (Eds.), Methods of Critical Discourse Analysis (pp. I-I3). London, UK: Sage Publications.

Wodak, R. (2009). The discourse of politics in action: politics as usual. Basingstoke, UK: Palgrave Macmillan.

Wodak, R. (2015). Critical discourse analysis: Discourse-historical approach. In The international encyclopedia of language and social interaction (First ed., PP. 275-288). John Wiley \& Sons. Doi: 10.1002/978 I I I86 I |463/wbielsi I 16

Wodak, R., \& Meyer, M. (20I5). Critical discourse studies: History, agenda, theory and methodology. In R. Wodak \& M. Meyer (Eds.), Methods of Critical Discourse Studies (3rd ed., Pp. I-22). London, UK: Sage.

Yankova-Dimova, G. (2018, June 29). Confused. [facebook post] Retrieved from: https://www.facebook.com/groups/ I64 I I8476947754/

Žižek, S. (2006a). Against the populist temptation. Critical Inquiry, 32(3), 55I-574. doi: 10.1086/505378

Žižek, S. (2006b). Schlagend, aber nicht treffend! Critical Inquiry, 33(I), I85-2I I. doi: |0.1086/50975 | 

NEDERLANDSTALIGE SAMENVATTING

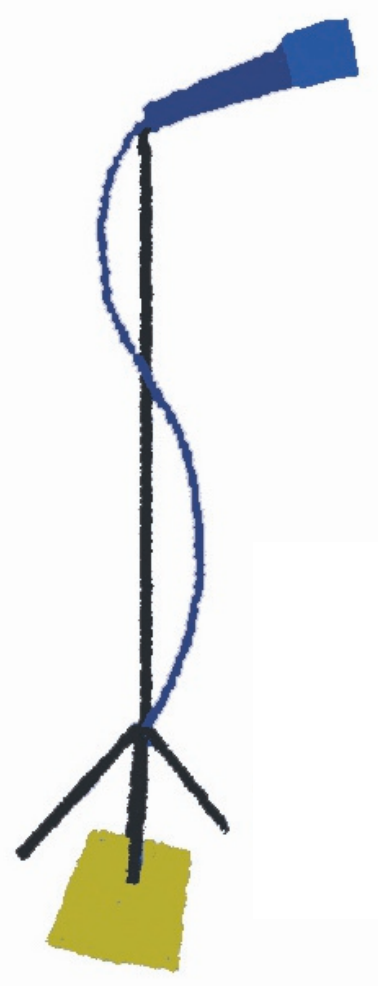




\section{De politieke betekenis van stijl}

Politiek optreden tussen populisme, elitisme en pluralisme.

De afgelopen vijftig jaar is de rol van stijl steeds belangrijker geworden in de politiek. Door ontwikkelingen in de media-zoals de opkomst van de smartphone en sociale platforms als Facebook en Twitter, wint de vorm van politieke uitingen aan invloed ten opzichte van de inhoud. Niet alleen wat politici zeggen doet ertoe, maar in steeds grotere mate ook hoe ze dat doen. Waar die vorm precies uit bestaat, is echter onduidelijk, want het concept politieke stijl is structureel onderontwikkeld. Waar de ene wetenschapper spreekt over retoriek, doelt de ander op het bredere begrip discourse. Weer andere wetenschappers wijzen op het sociale aspect van politieke stijl. Dit zorgt voor veel ruis in wetenschappelijke discussies over politiek, zoals de discussie over populisme; degenen die dit fenomeen zien als een politieke stijl blijken het vaak over verschillende dingen te hebben.

Onderzoek naar de rol van stijl in de politiek—zoals in deze dissertatie-begint daarom onvermijdelijk met het beantwoorden van de vraag: wat is politieke stijl? Een analyse van het concept wordt gepresenteerd in het theoretische hoofdstuk 2 van dit proefschrift. Samengevat is politieke stijl het "gestileerde optreden van politici op het politieke toneel met als doel het verschil tussen kiezer en gekozene te overbruggen met een politieke identiteit”. Er zijn drie dimensies betrokken bij politieke stijl, als gevolg van het feit dat politieke stijl en de politieke identiteit die het uitdrukt in en door discourse ontstaan.

Discourse verwijst naar de taal en cultuur van een groep in de ruimste zin van het woord: alles wat in een groep betekenis heeft, dus ook acties, mode, of de inrichting van ruimtes hoort bij discourse. Discourse omvat altijd drie dimensies: de dimensie van de ideeën (cognitie); de sociale dimensie (groepsrelaties), en de dimensie van de presentatie (taal, beeld, retoriek). Deze drie dimensies zijn terug te voeren op de drie fundamentele spanningen die er per definitie in discourse bestaan.

- Een eerste spanning in discourse bestaat in de relatie tussen het teken (in de taal) en het betekende (het ding). Deze relatie is in principe arbitrair en wordt bepaald door een sociale relatie waarin macht een rol speelt: het machtige subject geeft een naam aan het machteloze object. Een voorbeeld: ouders geven hun kind een naam. Een kind heeft daar geen macht over, terwijl deze naam nooit perfect past. Het kind kan pas een andere naam kiezen wanneer het zelf een mondig subject is geworden. Het verschil tussen 
machtig subject en machteloos object is de basisspanning in de sociale dimensie van discourse.

- Een tweede ingebouwde spanning in discourse is terug te voeren op de syntagmatische relatie tussen tekens. Dit is de spanning tussen het universele (genus) en het specifieke (species). Een voorbeeld: ook al voldoet geen enkele hond (species) precies aan het prototype van een hond (genus), toch is het onomstreden dat bijvoorbeeld een Chiwawa een hond is en geen konijn. Dat komt omdat de genus van een woord een extra betekenis heeft op een hoger abstractieniveau. Op basis daarvan wordt besloten wat een hond is en wat niet. Een genus heeft echter ook altijd een tekort, omdat het geen enkele hond in detail beschrijft. Deze spanning, veroorzaakt door een extra en een tekort aan betekenis, legt de basis voor een autonome dimensie van de ideeën in discourse, en heeft betrekking op categorisaties van woorden.

- Een derde ingebouwde spanning in discourse is terug te voeren tot de paradigmatische relatie tussen tekens; de mogelijkheid om meerdere betekenissen toe te kennen aan hetzelfde woord. Een voorbeeld: bleek is een tint, maar kan ook verwijzen naar een emotie en naar een schoonmaakmiddel. De relatie tussen de verschillende mogelijke betekenissen van een teken kan een metaforische zijn, waardoor de relatie tot stand komt op basis van identificatie van het ene teken met een ander. Het kan ook een metonymische relatie zijn. In dit geval wordt de betekenis benaderd door omschrijving van een onderdeel, zoals bij het schoonmaakmiddel bleek, dat genoemd is naar het effect dat het heeft op kleur. Dit speelt zich af in de dimensie van de presentatie.

Uit de semiotische analyse beschreven in hoofdstuk 4 blijkt dat deze drie fundamentele spanningen in discourse direct verband houden met politieke stijl: het zijn de drie spanningen die ook de relatie bepalen tussen drie gerelateerde politieke stijlen; populisme, elitisme, en pluralisme. Voor hierop verder in te gaan, volgt eerst een korte omschrijving van deze drie stijllabels.

Elitisme is een opvatting over democratie waarin het volk ongeschikt wordt geacht om het land te besturen. Daarom vindt men het beter dat de elite regeert. Leden van de elite zijn helpers van het volk en zorgen ervoor dat het land gedijt. Eliteleden competeren met elkaar om de gunst van het volk dat het recht heeft de beste leider te kiezen en slechte leiders af te zetten. Deze opvatting van democratie is tegenwoordig niet meer in zwang en heeft na de Tweede Wereldoorlog plaatsgemaakt voor een pluralistische opvatting over 
democratie. Pluralisme definieert het volk als een heterogene samenstelling van groepen en individuen. In het pluralisme heeft niemand het privilege van de macht; iedereen heeft in principe toegang tot de macht, maar alleen tijdelijk. De afspraak is dat de groep of politicus met de meeste steun tijdelijk mag regeren, onder voorwaarde dat de rechten van minderheden worden gerespecteerd. Ondanks het feit dat de meeste huidige westerse democratieën heden ten dage pluralistisch zijn, is elitisme niet helemaal verdwenen. Ook in een overwegend pluralistische context hebben elites vaak gemakkelijker toegang tot de macht dan mensen uit het gewone volk. Dit laatste is een veel gehoorde klacht in het populisme. Populisten eisen namens het volk de macht op, omdat alleen zij écht de stem van het volk vertegenwoordigen. De overige politici dansen volgens de populist naar de pijpen van de corrupte elite die alleen uit is op het eigen gewin.

Zoals gezegd, analyse van de onderliggende taalstructuur van populisme, elitisme en pluralisme laat zien dat deze structuur terug te voeren is op de drie fundamentele spanningen in discourse. Bij deze drie spanningen staan er altijd twee politieke stijlen tegenover de derde, in wisselende samenstelling, en wel als volgt:

- De ideeën-dimensie: pluralisme staat aan de kant van de species (het volk is een heterogene samenstelling van individuen en groepen) tegenover populisme/elitisme, aan de kant van de genus (het volk is een);

- De sociale dimensie: elitisme staat aan de kant van het machtige subject (macht aan de elite) tegenover pluralisme/populisme aan de kant van het machteloze object dat de macht eist om over zichzelf te beslissen (macht aan het volk);

- De presentatie-dimensie: populisme staat aan de kant van metaforische identificatie (identificatie met het volk) tegenover elitisme/pluralisme aan de kant van de metonymische benadering (representatie van het volk).

Omdat de drie dimensies van discourse circulair met elkaar verbonden zijn-ze veroorzaken elkaar en ze zijn elkaars gevolg—betekent dit dat ook populisme, elitisme en pluralisme circulair met elkaar zijn verbonden. Hierdoor vormen ze gedrieën een gesloten systeem: ze omvatten een logisch veld op grond waarvan alle voorkomende politieke stijlen kunnen worden gedefinieerd. Dit houdt in dat stijlen van politici eenduidig kunnen worden bepaald: een uitspraak is altijd pluralistisch of niet; vervolgens, als het niet pluralistisch is, dan valt het onder elitisme of niet; en wanneer dat ook niet het geval is, dan is het noodzakelijkerwijs 
populistisch. Soms is een uitspraak niet eenduidig, maar een stijl kan altijd ten minste worden gedefinieerd als een anti-stijl; datgene wat een stijl niet is. Dit komt overeen met de gezamenlijke kenmerken van de twee andere stijlen. Voor een stijlanalyse moeten dus zes stijllabels onderscheiden worden—drie stijlen en drie anti-stijlen—die gezamenlijk alle mogelijke politieke stijlen omschrijven.

Door nog verder in te zoemen op de drie dimensies van de drie stijlen, blijkt er nog een patroon te bestaan. Een politieke stijl is in principe een groepsstijl, omdat het functioneert om contact te leggen met een groep mensen. Echter, een pure groepsstijl bestaat niet, omdat groepen altijd bestaan uit individuen. Om groeps- en individuele belangen met elkaar te verzoenen, zijn er systemen nodig, bijvoorbeeld het systeem van een democratie, waarin meerderheids- en minderheidsbelangen worden afgewogen. Conceptuele analyse laat zien dat populisme, elitisme en pluralisme ieder op hun eigen manier een persoonlijke, groeps- en systematische stijl combineren, en weer in wisselende samenstelling precies elkaars tegengestelde en bondgenoot zijn in elke dimensie. Het zijn drie varianten van een groepsstijl waarin persoonlijke, groeps- en systematische elementen gelijkmatig over de drie dimensies zijn verspreid.

De drie stijlen lenen zich dus goed om gezamenlijk te gebruiken voor de analyse van politiek discourse, bijvoorbeeld speeches, maar ook manifesten, partijprogramma's, debatten of andere optredens. Om ervoor te zorgen dat de analyses op een vergelijkbare manier uitgevoerd worden, met aandacht voor dezelfde onderdelen, zijn er vijf focuselementen van politieke stijl gedefinieerd, gebaseerd op een analyse van de afzonderlijke dimensies. Deze focuselementen zijn: I) Het volk; 2) De politieke elite; 3) Democratie/regering; 4) Politiek; en 5) Politieke context. Van deze vijf elementen zijn beschrijvingen gemaakt voor de drie stijlen en hun anti-stijlen, die alle aan elkaar gerelateerd zijn. De beschrijvingen van deze vijf elementen in drie dimensies en zes stijlen (met in totaal 90 stijlelementen) zijn dus relatief: niets behoort objectief tot het populisme, elitisme of pluralisme - de elementen worden gedefinieerd ten opzichte van elkaar. De beschrijvingen vormen de kern van een methode voor de analyse van politiek discourse, de PEP-index (zie Appendix D). Met behulp van dit analyse model zijn speeches geanalyseerd en vergeleken in drie politieke contexten: de VS, het VK, en Nederland. Deze contexten zijn niet zonder meer vergelijkbaar; iets wat in Nederland tot het elitisme hoort, hoeft daar in Engeland niet toe te behoren. Pas nadat de analyses zijn uitgevoerd in de eigen context, worden ze vergelijkbaar op een hoger 
abstractieniveau. Door de resultaten van de analyses te plotten op een driehoekig veld, wordt duidelijk hoe ze zich ten opzichte van elkaar verhouden (zie de figuur SI).

Hoofdstuk 3 beschrijft een analyse van zes speeches van Amerikaanse politici tijdens de presidentiële voorverkiezingen van 2016: Bernie Sanders, Donald Trump en Hillary Clinton. Het hoofdstuk maakt gebruik van een eerste versie van het analyse-model, maar de analyses zijn later herhaald en bevestigd in de nieuwe versie. De analyses laten zien dat Trump in 2016 een volledige populistische stijl heeft, Bernie Sanders heeft een gemengd populistische-pluralistische stijl en Hillary Clintons stijl is een mix van pluralisme en elitisme. De analyse laat verder zien dat Sanders en Trump elkaar alleen benaderen in hun stijl op Focuselement 4 Politiek: beiden zien en bedrijven ze politiek als een gevecht tegen de elite. Ze verschillen het meest in hun ideeën over het volk: Sanders heeft een pluralistische conceptie van het volk (het volk is heterogeen), en Trump een populistische (het volk is een).

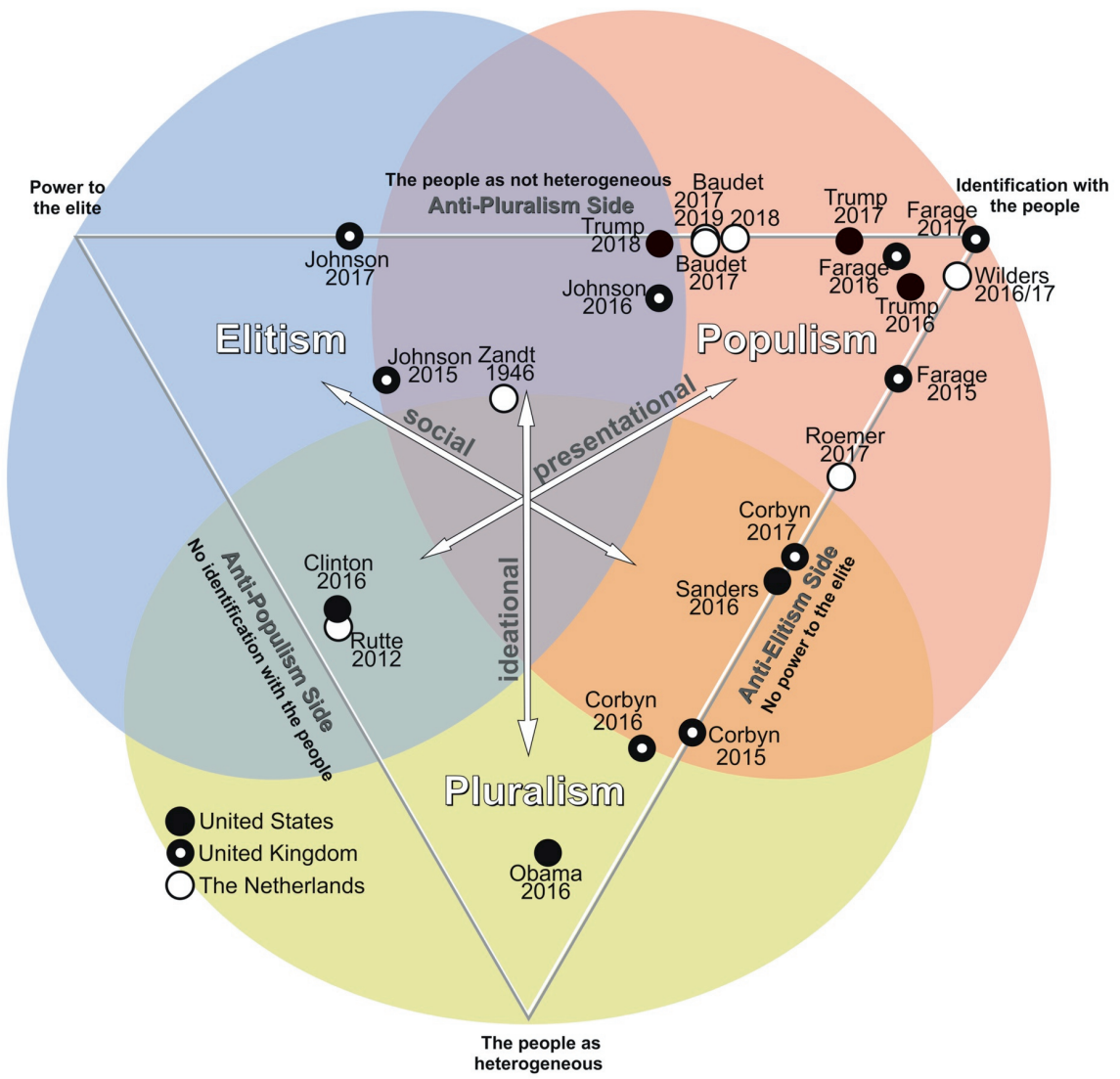

Figure SI 
Hoofdstuk 4 beschrijft de eerdergenoemde semiotische analyse van populisme, elitisme, en pluralisme en legt uit hoe de onderliggende structuur van populisme de verschillende stromingen in het populisme-onderzoek met elkaar verbindt. Al deze stromingen zijn geheel of gedeeltelijk terug te voeren op de onderliggende structuur. Omdat de drie dimensies elkaar deels tegenspreken, is het onmogelijk om alle manifestaties van populisme tegelijk in één interne coherente definitie te vatten. Dit verklaart waarom er geen consensus is in de discussie over de aard van populisme. Een sluitende definitie van populisme is onmogelijk, want populisme is iets wezenlijks anders in verschillende dimensies. Alleen door vanuit drie verschillende invalshoeken naar populisme te kijken, worden alle elementen van populisme zichtbaar. Pas daarna kan bekeken worden in welke dimensie de desbetreffende uiting van populisme zich het meest afspeelt.

Hoofdstuk 5 beschrijft het analyse-instrument gedetailleerder en past het toe in een analyse van drie min of meer populistische politici in drie politieke contexten. Voor de VS zijn de speeches van Donald Trump en Bernie Sanders uit hoofdstuk 3 vergeleken met een speech van Barack Obama uit 2016. De analyse laat zien dat Sanders' politieke stijl precies het midden houdt tussen die van Trump en Obama: waar Trump een dominante populistische stijl heeft en Obama een dominante pluralistische stijl, heeft Sanders een gemengd pluralistische-populistische stijl. Obama's populisme is vooral sociaal bepaald; het is voornamelijk anti-elitisme, wat evengoed te vangen is onder de noemer van pluralisme. Ook Sanders' populisme is vooral sociaal, terwijl hij in de andere dimensies gedeeltelijk populistisch is. Trump is populistisch in alle drie de dimensies. Ook in het VK zijn speeches geanalyseerd van politici die vaak als populist worden gekarakteriseerd: Boris Johnson, Jeremy Corbyn en Nigel Farage (in 2016 en 2017). Opvallend is dat Corbyns stijl dicht bij die van Sanders komt, en Farage's stijl dicht bij die van Trump. Johnsons stijl is van een geheel andere orde: hij is hoofdzakelijk een elitist, en mengt dit met populisme, vooral tijdens de Brexit-campagne. In Nederland zijn drie populistische politici tijdens de verkiezingen in 2017 geanalyseerd: Geert Wilders, Thierry Baudet en Emile Roemer. Opvallend is dat alle drie volle populisten zijn. Emile Roemer zit wel aan de pluralistische kant van het populisme, en Baudet aan de elitistische kant, maar de verschillen zijn beduidend minder groot dan in de VS en het VK.

Hoofdstuk 6 zoemt verder in op de politieke stijl van drie van de reeds geanalyseerde politici: Trump, Johnson en Baudet. Van alle drie zijn speeches geanalyseerd die verspreid over meerdere jaren zijn gehouden, om ook ontwikkelingen in hun stijl te kunnen zien. 
Trumps stijl blijkt na zijn inauguratie tot president in 2016 langzaam op te schuiven van populisme naar gemengd populisme/elitisme in 2017/20I8. Op deze manier kan hij zijn rol als president verenigen met zijn populistische identificatie met het volk. Hij doet dat door het volk onderdeel te maken van zijn succes, en ook door het volk en hemzelf als de echte elite te bestempelen, en zijn tegenstanders als nep elite. Een soortgelijke strategie hanteert Baudet, gebaseerd op analyses van speeches uit 2017, 2018 en 2019. Hijzelf is duidelijk deel van de echte elite, in tegenstelling tot andere politici, die niet tot de (intellectuele) elite behoren; zij hebben volgens Baudet "nog geen boek in hun hele leven gelezen”. Het Nederlandse volk is, doordat zij de erfgenamen zijn van een verheven cultuur, ook onderdeel van de elite, terwijl niet-westerse culturen niet tot de elite behoren. Hiermee verzoent hij zijn elitaire imago met zijn populistische vereniging met het volk. Johnson is, zoals gezegd, meer een elitist dan een populist. Hij hoeft het volk niet te verenigen met de elite, want hij presenteert zichzelf nooit als onderdeel van het volk. Hij is wel onderdeel van Engeland, een ander concept dat de elite en het volk verenigt. De populistische-elitistische stijlmix van deze drie politici blijkt goed samen te gaan met nationalisme en nativisme: de mix verenigt het volk en de elite onder één vlag.

Hoofdstuk 7 en een deel van hoofdstuk 8 bevat een theoretische verkenning van het verband tussen metaforen en politieke stijl. Niet verwonderlijk is dat de drie dimensies ook terug zijn te vinden in de drie doelen waarmee metaforen in het politieke discourse worden gebruikt. Deze drie doelen komen ook overeen met de Aristoteles' triade ethos-logospathos. Hiermee wordt een theoretisch verband gelegd tussen populisme en pathos, elitisme en ethos, en pluralisme en logos. Verder laat de verkenning zien dat metaforen een cruciale rol spelen in het populisme: populisme is de politieke vertaling van metaforische identificatie in taal en discourse. De populistische politicus is hierbij zelf, met zijn of haar gehele optreden, een metafoor voor het volk. Populisten maken op deze manier het volk direct, metaforisch, aanwezig in het politieke veld.

In hoofdstuk 8 wordt onderzocht of bovenstaand verband tussen populisme en metaforen ook zichtbaar is in een ander metafoor gebruik door populisten ten opzichte van elitisten en pluralisten. Hiertoe zijn drie speeches die al waren geanalyseerd op politieke stijl verder geanalyseerd op metafoorgebruik. De populistische speech was van Geert Wilders, de speech met kenmerken van het elitisme van Boris Johnson, en de pluralistische speech van Barack Obama. De analyse van de speeches laat zien dat alle politici metaforen gebruiken die betekenis genereren in alle drie de dimensies. Daar is dus geen onderscheid in, wat is te 
verklaren uit de circulaire relatie tussen de drie dimensies. Het overkoepelende doel van het metafoorgebruik in de speech is echter wel verschillend voor de drie stijlen, en in overeenstemming met het verband tussen populisme en pathos, elitisme en ethos, en pluralisme en logos. Analyse van meer speeches zou dit verband verder moeten bevestigen. De analyse identificeert ook een metafoor die typerend is voor populisme: de oorlogsmetafoor voor politiek waarbij de politieke tegenstanders als aartsvijanden worden afgebeeld. In elitisme en pluralisme druist deze metafoor direct tegen de politieke betekenis van deze stijlen in. Als er al oorlogsmetaforen worden gebruikt, zijn het geen directe metaforen voor politiek, maar is er sprake van een gelaagde metafoor. De oorlog verwijst dan naar de metafoor die de politiek uitbeeldt als een competitief spel of sport (elitisme), of naar de metafoor die de politiek ziet als een opdracht of uitdaging (pluralisme).

De conclusie, in hoofdstuk 9, beziet de resultaten van de conceptuele en empirische analyses in het licht van de bestaande literatuur over politieke stijl, populisme en metaforen. Op de eerste plaats levert deze dissertatie een bijdrage aan de ontwikkeling van het politieke stijlconcept. Met name de drie dimensies van politieke stijl en de relatie tussen populisme, elitisme en pluralisme met de drie spanningen in discourse is nieuw. Ook nieuw is de definitie van politieke stijl als een groepsstijl, waarbij elementen van een groepsstijl worden gecombineerd met persoonlijke en systematische stijlelementen. Deze verdere differentiatie geeft de mogelijkheid om meer gedetailleerd naar stijlverschillen te kijken. De speech analyses wijzen verder op een mogelijk verband tussen politieke stijl en het politieke spectrum van links-midden-rechts. Er zijn aanwijzingen dat de populisme-pluralisme-mix overeenkomt met links-populisme, en de populisme-elitisme-mix met rechts-populisme. Speech analyses van andere politieke contexten moeten uitwijzen of dit patroon breed zichtbaar is.

Aan de conceptualisering van populisme draagt deze dissertatie bij door de ontdekking van de onderliggende discursieve structuur van populisme. Deze structuur legt de link tussen verschillende stromingen in het populisme-onderzoek. Hoewel alle afzonderlijk onderdelen van deze structuur op zich wel bekend waren, was het onduidelijk hoe zij samenhingen. Deze samenhang is wat deze dissertatie bijdraagt aan het populisme-onderzoek. Dit brengt ook duidelijkheid in discussies tussen de verschillende stromingen in dit onderzoek, bijvoorbeeld met betrekking tot de vraag of het volk in het populisme homogeen is of niet. De analyse in deze dissertatie laat zien dat dat kan, maar niet noodzakelijk is; het volk kan ook verenigd zijn, zolang het maar met een mond kan spreken. 
De dissertatie draagt verder bij aan de theorievorming rond populisme als een daad (act), zoals geformuleerd door Laclau (2005). Laclau defineert populisme als de retorische daad van samenbrengen van allerlei vormen van onvrede in de maatschappij onder de noemer van het volk en als één gezamenlijke aanklacht tegen de machthebbers; dit refereert aan de presentatie dimensie van populisme. Naast deze populistische daad, waarin de machthebbers een metafoor worden van alles wat er mis is in de maatschappij, en het volk een metafoor voor de onvrede, omvat de politiek nog twee daden: een met wortels in het pluralisme en in het elitisme.

De pluralistische daad bestaat uit het ontleden van de dominante frames in de maatschappij, die algemeen worden geaccepteerd als waarheid, maar die ook maar een versie van de werkelijkheid weergeven. Deze frames zijn vaak gunstig voor bepaalde politieke belangen, en alleen door te laten zien dat deze frames niet waar zijn, is er verandering mogelijk. Deze daad is pluralistisch omdat zij terug te voeren is op de spanning in discourse tussen het algemene en het specifieke (genus-species).

De elitistische daad houdt in dat mensen niet in de politiek actief zijn voor eigen gewin, maar om anderen te helpen. Hoewel elitisme vaak bekritiseerd wordt als precies het tegenovergestelde, is het idee achter elitisme altruïstisch; mensen die een betere positie in de samenleving hebben, zijn verplicht om de minder bedeelden te helpen door voor het grotere belang te werken. Het volk en de elite zijn niet noodzakelijkerwijs tegenstanders; ze kunnen elkaar ook helpen. De goede intentie van elitisme wordt weinig onderkend, maar juist dit altruïstisme is een derde onmisbare politieke daad, omdat zij de enige manier is om vrede te bereiken tussen individuen en groepen mensen nadat de populistische en pluralistische gevechten zijn gevoerd. Daarom zijn alle drie de politieke stijlen een noodzakelijk onderdeel van politiek; populisme evenveel als elitisme en pluralisme.

Verder levert deze dissertatie een bijdrage door de introductie van een nieuwe methode voor de analyse van politieke teksten en optredens, de PEP-index. Het grote voordeel van de PEP-index is dat het een gedetailleerd inzicht geeft in de verschillen tussen politieke stijlen die op allerlei aspecten met elkaar kunnen worden vergeleken. Dit levert nieuwe inzichten op in politieke situaties, zoals te zien is in de samenvattingen van de hoofdstukken.

Ten slotte laat deze dissertatie zien hoezeer metaforen van belang zijn voor het populisme. Een populist is zélf een metafoor voor het volk; een volk dat zich machteloos voelt omdat het niet in staat is zijn situatie te veranderen, en daar toch iets aan wil doen. Een 
metafoor, echter, is niet in eerste instantie bedoeld om te ontleden (logos), maar te laten voelen (pathos). De echte betekenis van populisme is dan ook een roep om empathie en erkenning. Een logisch antwoord hierop is te hulp schieten, zoals een elitist zou doen. Deze roep proberen te begrijpen en ontleden, zoals een pluralist zou doen, is daarnaast nodig om te begrijpen waar deze roep om erkenning op stoelt, als de empathie niet van nature opkomt. Echter, een populistisch antwoord-het zelf vragen om erkenning en empathielevert geen perspectief op een oplossing, maar een patstelling. Alleen door een samenspel van de drie politieke stijlen- populisme, elitisme en pluralisme-zijn dit soort politieke impasses te doorbreken. 



\section{VALORIZATION ADDENDUM}




\section{Relevance}

Populism is on the rise as a global phenomenon, causing polarization and societal unrest. This dissertation provides a new perspective on this political development. Subsequently, this new vision on populism is used in the construction of an analysis tool for political style.

The tool helps to gain insight into political situations and events, such as the US presidential campaign of 2016. In this campaign, Donald Trump uttered right-wing populist rhetoric, while Bernie Sanders used a left-wing populist narrative. How can these similarities be assessed? The tool provides a transparent method for analyzing political discourse. Distinct political styles are mapped onto the same fifteen elements, which demonstrates in detail where the styles of politicians differ or not. In the cases of Sanders and Trump, it revealed Trump as more populist than Sanders. The two styles only converge in their attitude towards politics: both see politics as conflict. They diverge the most in their ideas regarding the people: in Trump's view, the people are one, whereas Sanders views the people as heterogeneous.

The analysis tool is called the PEP-index, an abbreviation of populism, elitism, and pluralism $^{29}$. The reason is that the tool uses a relative definition of populism: nothing is populist in itself, only in relation to elitism and pluralism. This is a great advantage because the concept of populism is contested when regarded on its own; it frequently contradicts itself, which is why researchers not always agree on what counts as populist and what does not. Based on an analysis of the language structure underlying the three concepts, this dissertation was able to define populism (and elitism and pluralism) according to one logical rule. This rule is that the shared features of two of the three concepts precisely contradict the third. This clear-cut relationship makes the three concepts ideal as the basis of an analysis instrument, as they unambiguously define what is populist and what not. The contradictions exist in three different dimensions (if occurring in one dimension, populism would indeed contradict itself), as follows:

- Populism as an idea aligns with elitism (both see 'the people' as one entity). Together they oppose pluralism, which does not see the people as 'one,' but as multiple groups.

\footnotetext{
${ }^{29}$ In populism, the people demand power back from the corrupt elite. Elitism bestows power upon the elite, chosen by the people. In pluralism, groups of people share power.
} 
- Populism as a social practice aligns with pluralism (both want power for the people(s)). Together they oppose elitism, which restricts power to the elite.

- Populism as a rhetorical presentation stands opposite to a united pluralism-elitism; populism speaks directly for the people, whereas pluralism and elitism have a mediated relationship.

An additional advantage of using this logic as the core of an analysis tool is that it can address more than just populism—all political styles, including the mainstream, can be assessed. This allowed me to use the same tool to compare Trump's and Sanders's populist style with that of Hillary Clinton and Barack Obama. The tool reveals that Clinton has a mixed pluralistelitist style, and Obama a pluralist one. Whereas the latter succeeds in positioning himself diagonally against Trump, whom Obama disregards as an elitist, Clinton often takes the position of an elitist herself, while she also portrays herself as part of the people, which is populist or pluralist. For example, she presented herself as an extremely busy politician working for a higher cause, apologizing for not having time to socialize with the people (elitist). At the same time, she depicted herself as a common woman going to the grocery store with her black and Latino sisters (pluralist), and she protested against the unfair treatment of herself as a woman (populist/pluralist). The combination of three styles within one style element is not plausible-logically, only two of the three styles can be combinedand can explain why her performance was often assessed as unauthentic.

The PEP-index also allows intercultural comparison and assessments over time; after evaluating political styles within their own contexts, they also become comparable on a higher level of abstraction. Speeches held by Trump in three different years were analyzed, showing that his style shifted from populism towards mixed populism-elitism. This allowed him to keep his populist style while embracing his elite role as president. Subsequently, Trump's style was compared with mixed populist-elitist politicians in other countries: Boris Johnson in the UK and Thierry Baudet in the Netherlands. It revealed that the populist-elitist style mix often goes hand in hand with nationalism, and that it comes with an undemocratic tendency; the mix facilitates the construction of an "elite people", which is not democratic.

The analysis of Johnson's speeches also provided insight into the Brexit process. Johnson's style was much more populist during the Brexit referendum campaign than before and after, which can be explained by the polarizing incentives of a referendum. His style gradually evolved from pluralist-elitist in 2015 , into populist-elitist in 2016 , to fully elitist in 
2017. The latter two are predominantly anti-pluralist styles. The assemblage of Johnson's style suggests that anti-pluralism fits him better than pluralism, as his 2016 and 2017 styles were internally more coherent than his mixed elitist-pluralist style in 20I5. In the future, Johnson's style can be further explored using the PEP-index, in order to evaluate how his style evolves as Prime Minister negotiating Brexit and coping with the Corona crisis. Because the PEP-index covers all political styles, it can continuously provide relevant analyses of new political situations.

\section{Stakeholders}

Besides the general public for which this dissertation provides a new perspective on populism and other political developments, as described above, this work is relevant for three groups.

\section{People working in politics.}

The PEP-index offers politicians the opportunity to evaluate their own presentation, both independently and in relation to their opponents. The model is fit not only to analyze political speeches and debates, but also to reflect on various fragmented and mediatized political presentations, such as outfits, YouTube video's, Twitter threads, and public encounters.

Analyzing political performances with the PEP-index reveals whether or not a style is internally coherent. The analyses in this dissertation suggest that it is more persuasive to express one's own style - be it populist, elitist, or pluralist - than to imitate styles that do not fit with one's political message and identity. For a coherent political style, small details matter. For the one politician it may be better to use "we" when referring to the people, for the other "they"-both can be persuasive. For instance, in speeches surrounding the Brexit referendum, Nigel Farage consistently used "we” when he spoke of the people. This fitted with his populist identity. Boris Johnson, on the other hand, always used "they," which perfectly matched his elitism. Both politicians were very successful during the Brexit referendum, showing that it was not their populist "we" or elitist "they" that was decisive, but rather the internal coherence of their styles. Words, even nuances such as pronouns, must match with one's personality and ideas to construct a stable and believable political 
identity. Rhetorical craftmanship shows itself when every word or gesture precisely fits a particular political identity.

An often-debated question is whether or not mainstream politics-left, center, or right-should adopt a more populist discourse in order to effectively compete with populist parties. Generally speaking, if politicians wish to enhance their presentation, it is more effective to change a detail of one's style, than to adopt a style that contradicts one's political personality. All styles are constructed out of three dimensions, which are either styled in a personal, group, or systematic way (see chapter 2.7 and 4.5). It then follows that one can choose to change the style of just one dimension, by making it more personal, more social, or more systematic. By zooming in on the details, one can enhance one's presentation without becoming internally incoherent.

\section{A politically active public.}

This dissertation does not, unlike many other contributions on populism, generally condemn populist politics as morally defective, nor does it advocate it as an effective strategyinstead, it offers a model that can place populist manifestations within a broader perspective. This clarifies Chantal Mouffe's (2018a) plea for a left-wing populism. As a scholar-activist, she advocates populism as an effective political strategy. Others, such as Žižek, warn that this strategy uses scapegoats and creates an enemy. In doing this, it equals right-wing populism (Žižek, 2006a). It is a discussion that engages many politically active people on the left.

This dissertation shows that left-wing populism is principally different from right-wing populism; right-wing populism's main perspective is the ideational dimension, centered around whether ideas are right or wrong, whereas left-wing populism's main perspective is the social dimension, centered around whether social practices are fair or unfair. The manifestations of both may be similar, as what is fair is easily equated with what is right and vice versa. Additionally, both combine their particular view with the perspective of the people against the political class, presenting themselves as we against them-here Žižek is right. However, the deeper underlying structures of left- and right-wing populism are principally different-which supports Mouffe's point. One can still object to scapegoating politics as a whole, using a we-against-them theme, but it is not essentially right-wing to do so. 


\section{Watchdogs over our democracy.}

The analysis of political styles in this dissertation puts the current populist wave in perspective. The discursive structure underlying political style demonstrates that no style is here to stay: all political styles try, in their own ways, to overcome the tensions inherent in discourse, all ultimately without success. It then follows that new political styles will inevitably evolve in reaction to the weaknesses of current styles and events. The 2020 Corona crisis, for example, pushes many leaders to change their style in one or the other direction. Some may tend more towards pluralism, stressing the importance of relying on objective knowledge about the virus, as in the Netherlands and Germany. Others tend more towards elitism, prioritizing a strict adherence to government regulations, such as in Italy, Spain, and France. Populist leaders, like in the US, Hungary, and Brazil, currently face major problems with their political message because a virus is essentially a non-populist struggle; it naturally aligns more with pluralism and elitism, as in a pandemic there is no internal frontier in society between the people and the elite but an external frontier between all people and a virus. Nevertheless, the crisis also facilitates undemocratic measures, which can result in populist leaders not becoming less populist, but instead less democratic.

The coming years will reveal if populism is here to stay as an influential democratic practice, or if other political styles will become more prominent. Detailed insight into the political styles of politicians, such as is offered in this dissertation, can help to maintain a healthy democratic environment. In this environment, populism, elitism, and pluralism can function as political styles that mostly stay on a democratic spectrum. Awareness, however, is needed, and a detailed analysis of political performances can help to reveal whether or not political styles are democratically justified, or not.

\section{Activities}

In order to share my findings with a broader public, I have presented my work on various platforms. In 2017, in New York, I presented my research at an event of The Order of the Prince (www.ovdp.net), an organization upholding the Dutch language and culture. In Edinburgh, I presented my research at an aimed at the broader public: the World Café (https://blogs.napier.ac.uk/popnat/8/2018/05/29/schoor_masstricht_university). 
Furthermore, since 2014 I have been publishing articles for a broad public (in Dutch) on my blog Aristoteles op het Binnenhof (www.aristoteles.nu) and (www.facebook.com/pg/aristoteles.op.het.binnenhof).

\section{In the future}

In the near future, I will seek to further valorize the findings of my dissertation in three distinct ways.

First, I intend to partially take up my old profession as a Political Communication Advisor in The Hague. I will offer my advice to political stakeholders in order to help them assess and enhance their political performance. My goal is to enlarge politicians' understanding of how to strengthen their bond with their own group of voters. This is important in allowing our democracy to adapt to the image-driven, presentation-centered political context in which it now functions. Knowledge of the deeper structures that underly political communication is, in my view, necessary for reinforcing democracy's resilience against anti-democratic tendencies.

Second, I will offer lunchbreak lectures to organizations such as the Communication Departments of Ministries, Political Parties, and non-governmental organizations. Also, I will publish more often for a broader public, both in my blog and in a book on politics and style. Besides this, I will work on a textbook for bachelor students on the topic of political style.

Third, and most urgently, I will seek funding for the further development of the PEPindex. Ideally, the tool will be published as a web-based program or an app. The foundation is already in place but needs technical support to make it more broadly accessible. This tool will give various stakeholders - such as students, researchers, and political communication professionals - the opportunity to analyze political performances in a transparent and standardized manner. They will be able to upload their analysis to the site and compare it with analyses uploaded by others. This way, the app will fuel cooperation and hopefully contribute to the growing knowledge of the politics of style. 


\section{Biographical note}

Carola Schoor (born I5th May 1964, s-Hertogenbosch) started her Ph.D. at Maastricht University, approximately twenty-five years after obtaining two master's degrees at the Radboud University Nijmegen. In 1987, she earned a master's in Dutch Language and Literature, with a thesis on individualism, collectivism, and gender in the work of the Dutch writer and philosopher Carry van Bruggen. In 1988, she completed a second master's in Literary Studies with a thesis on metaphor in the work of the American writer Djuna Barnes. Her pre-university education took place at the Jeroen Bosch College in sHertogenbosch.

After her studies, Carola Schoor worked as a journalist, editor, and editor-in-chief, in the field of educational research and politics. In 2002, she moved to Brussels for family reasons. There, she worked as a political communications officer for a Member of the European Parliament. Back in The Hague, in 2006, she worked as a liaison with Dutch parliament for the Dutch Association of Universities. When family circumstances, again, set her to live abroad - in Luxemburg in 2009 and in New York in 2014-she decided to regard political language from an academic perspective by working on a Ph.D.

During her Ph.D. trajectory, she published in several peer-reviewed academic journals (Discourse and Society, Populism, Critical Discourse Studies, and Metaphor and the Social World). She also wrote chapters for edited volumes and presented her work at international conferences on populism and discourse (in the USA, the UK, and Spain). In addition, she contributed to academic journals as a peer-reviewer. 